Nevada

Environmental

Restoration

Project

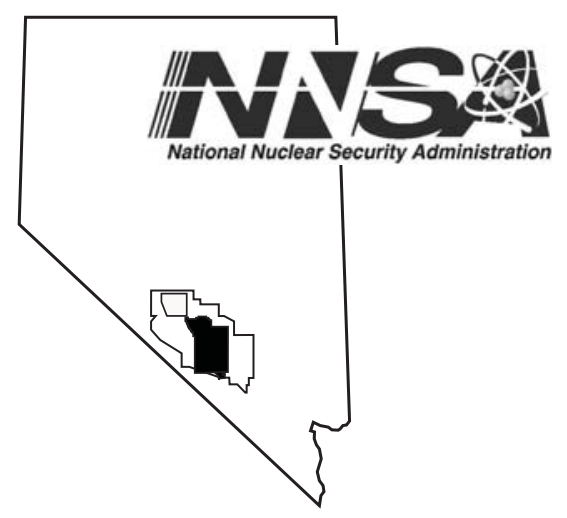

\title{
Completion Report for Well Cluster ER-5-3
}

December 2005

\section{Environmental Restoration}

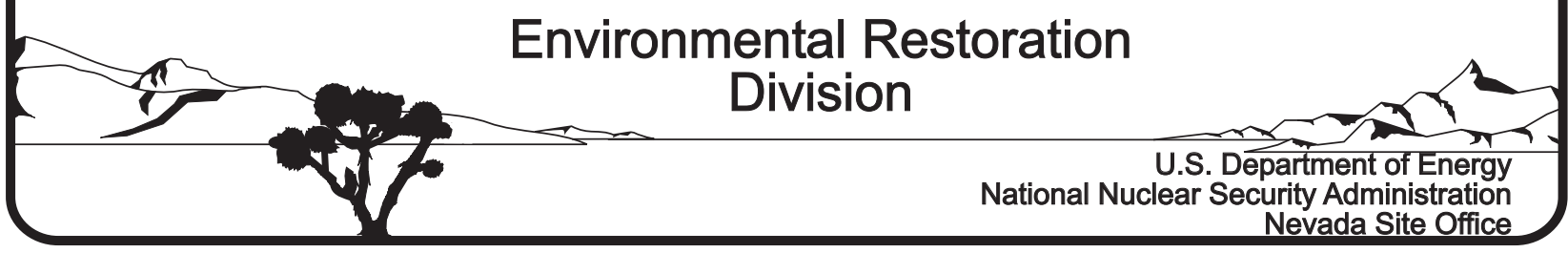




\title{
DISCLAIMER STATEMENT
}

Reference herein to any specific commercial product, process, or service by trade name, trademark, manufacturer, or otherwise, does not necessarily constitute or imply its endorsement, recommendation, or favoring by the U.S. Government or any agency thereof.

\section{AVAILABILITY STATEMENT}

Available to the public, in paper, from:

\author{
U.S. Department of Commerce \\ National Technical Information Service \\ 5285 Port Royal Road \\ Springfield, VA, 22161-0002 \\ Telephone: 800.553 .6847 or 703.605 .6000 \\ Fax: 703.605.6900 \\ E-mail: orders@ntis.gov \\ Online ordering: http://www.ntis.gov/ordering.htm
}

Available electronically at http://www.osti.gov/bridge.

Available for a processing fee to U.S. Department of Energy and its contractors, in paper, from:

U.S. Department of Energy

Office of Scientific and Technical Information

P.O. Box 62

Oak Ridge, TN 37831-0062

Telephone: 865.576.8401

Fax: 865.576.5728

E-mail: reports@adonis.osti.gov 


\title{
Completion Report for Well Cluster ER-5-3
}

\author{
Prepared for \\ U.S. Department of Energy \\ National Nuclear Security Administration \\ Nevada Site Office \\ Las Vegas, Nevada
}

Prepared by

Bechtel Nevada

Geotechnical Sciences

Las Vegas, Nevada

December 2005 
This page intentionally left blank. 
DOE/NV/11718--1093

\section{COMPLETION REPORT FOR WELL CLUSTER ER-5-3}
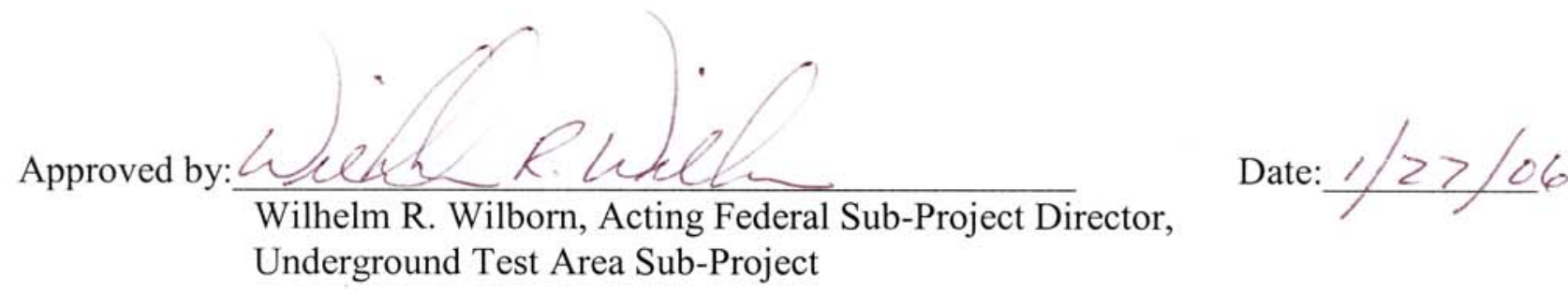

Underground Test Area Sub-Project

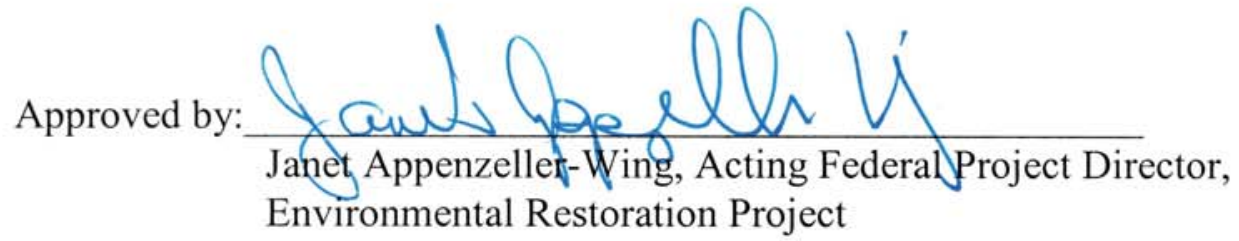

Date: $1 / 27 / 06$ Environmental Restoration Project 
This page intentionally left blank. 


\title{
Completion Report for Well Cluster ER-5-3 \\ DOE/NV/11718--1093
}

\begin{abstract}
Well Cluster ER-5-3 was drilled for the U.S. Department of Energy, National Nuclear Security Administration Nevada Site Office in support of the Nevada Environmental Restoration Project at the Nevada Test Site, Nye County, Nevada. This cluster of 3 wells was drilled in 2000 and 2001 as part of a hydrogeologic investigation program in Frenchman Flat.
\end{abstract}

The first borehole in the cluster, Well ER-5-3, was drilled in February and March 2000. A 47.0-centimeter surface hole was drilled and cased off to the depth of 374.8 meters. The hole diameter was decreased to 31.1 centimeters for drilling to a total depth of 794.3 meters within welded ash-flow tuff. A piezometer string with 1 slotted interval was installed in the annulus of the surface casing, open to the saturated alluvium. A completion string with 2 slotted intervals was installed in the main hole, open to saturated alluvium and to the welded tuff aquifer. A second piezometer string with 1 slotted interval open to the welded-tuff aquifer was installed outside the completion string.

Well ER-5-3\#2 was drilled about 30 meters west of the first borehole in March 2000, and was recompleted in March 2001. A 66.0-centimeter hole was drilled and cased off to the depth of 613.8 meters. The hole diameter was decreased to 44.5 centimeters and the borehole was drilled and cased off to the depth of 849.0 meters. The hole diameter was decreased once more to 31.1 centimeters for drilling to a total depth of 1,732.2 meters in dolomite. A completion string open to the dolomite (lower carbonate aquifer) was installed.

Well ER-5-3\#3 was drilled approximately 30 meters north of the first 2 boreholes in February 2001. A 66.0-centimeter hole was drilled and cased off to the depth of 36.6 meters, then the main 25.1-centimeter-diameter hole was drilled to a total depth of 548.6 meters in alluvium. A slotted stainless-steel tubing string was installed in the saturated alluvium.

A preliminary composite, static water level was measured at the depth of 282.6 meters, prior to development and hydrologic testing.

Detailed lithologic descriptions and stratigraphic assignments are included in the report. These are based on composite drill cuttings collected every 3 meters, and 120 sidewall samples taken at various depths below 91 meters in Wells ER-5-3 and ER-5-3\#2, supplemented by geophysical log data. The wells penetrated Quaternary/Tertiary alluvium to the depth of 622.4 meters, and an 8.5-meter-thick basalt flow was encountered within the alluvium. Tertiary tuff was penetrated to the depth of approximately 1,425.9 meters, where the top of the lower carbonate aquifer was tagged in Well ER-5-3\#2. 
This page intentionally left blank. 


\section{Table of Contents}

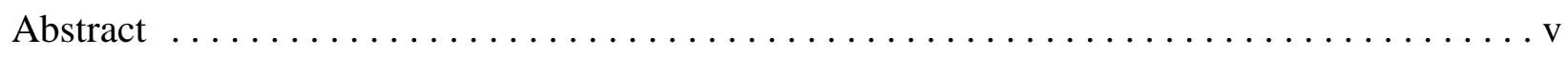

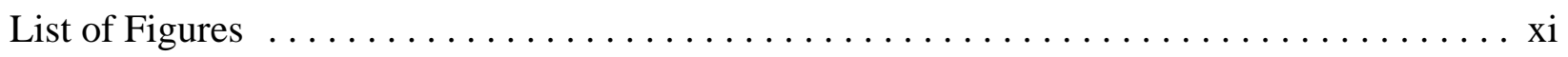

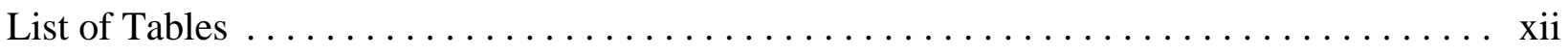

List of Acronyms and Abbreviations $\ldots \ldots \ldots \ldots \ldots \ldots \ldots \ldots \ldots \ldots \ldots \ldots \ldots \ldots \ldots \ldots \ldots$

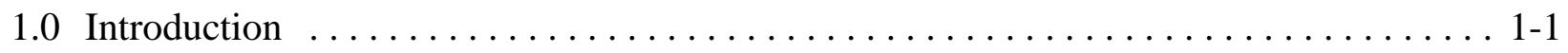

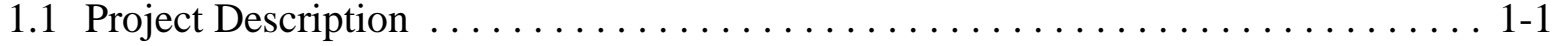

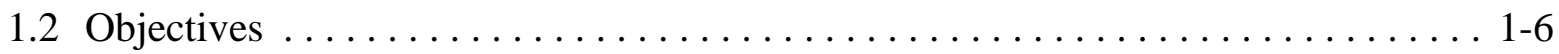

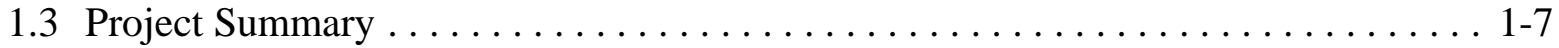

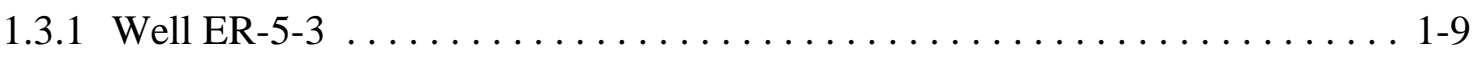

1.3.2 Well ER-5-3\#2 ................................ 1-10

1.3.3 Well ER-5-3\#3 . ............................... 1-10

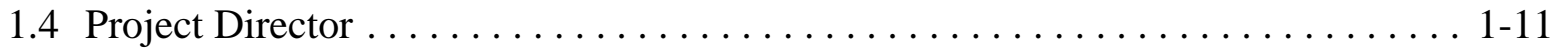

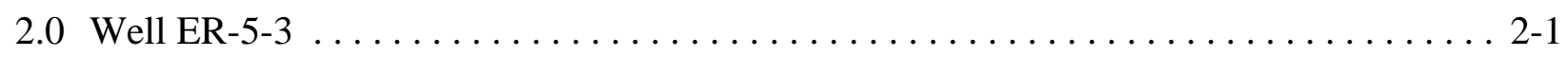

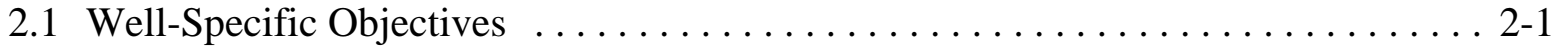

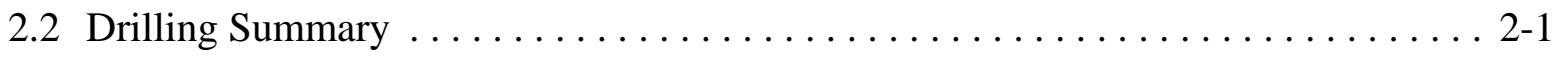

2.2 .1 Introduction $\ldots \ldots \ldots \ldots \ldots \ldots \ldots \ldots \ldots \ldots \ldots \ldots \ldots \ldots \ldots \ldots \ldots \ldots \ldots \ldots, 1$

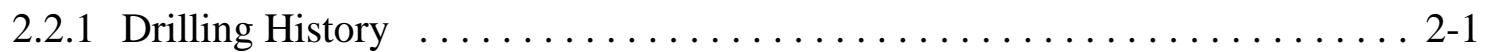

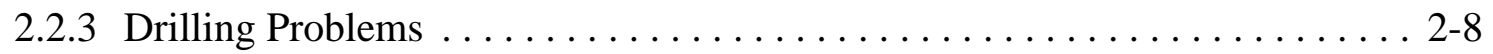

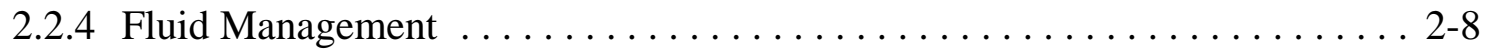

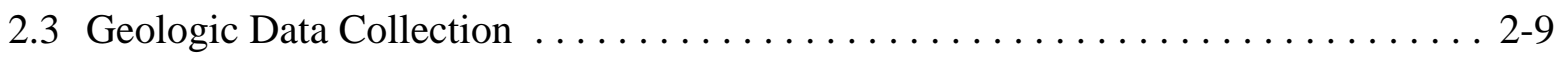

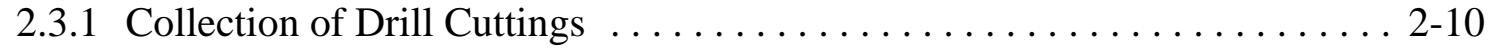

2.3 .2 Sidewall Core Samples ............................. 2-10

2.3 .3 Sample Analysis .................................. 2 2-13

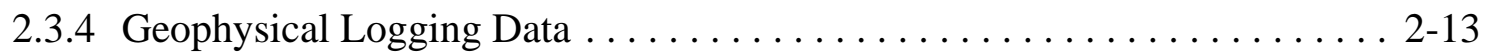

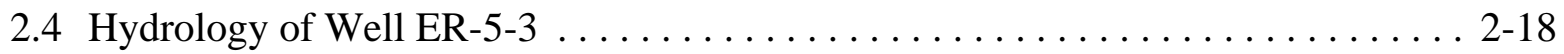

2.4.1 Preliminary Water Level Information $\ldots \ldots \ldots \ldots \ldots \ldots \ldots \ldots \ldots . \ldots \ldots$

2.4.2 Preliminary Water Production Information $\ldots \ldots \ldots \ldots \ldots \ldots \ldots \ldots . . \ldots \ldots$

2.4.3 Preliminary Thermal Flow Log Data $\ldots \ldots \ldots \ldots \ldots \ldots \ldots \ldots . . \ldots \ldots$

2.4.4 Preliminary Groundwater Characterization Samples ............... 2-19

2.5 Precompletion and Open-Hole Development . . . . . . . . . . . . . . . . . . . . 2-19 


\section{Table of Contents (Continued)}

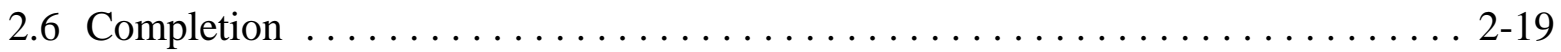

2.6.1 Proposed Completion Design ......................... 2-23

2.6.2 As-Built Completion Design $\ldots \ldots \ldots \ldots \ldots \ldots \ldots \ldots \ldots \ldots \ldots \ldots \ldots \ldots \ldots \ldots \ldots .2-23$

2.6.3 Rationale for Difference Between Actual and Proposed Well Design . . . . 2 2-24

2.6.4 Completion Method ............................... 2-24

2.7 Actual Versus Planned Costs and Scheduling for Well ER-5-3 . . . . . . . . . . . 2-26

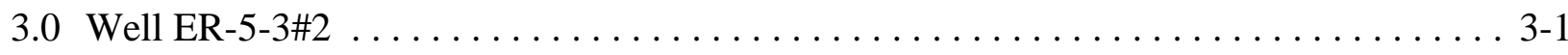

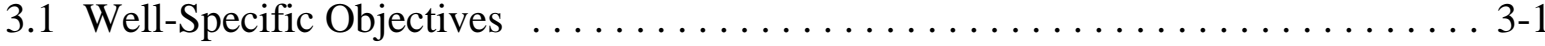

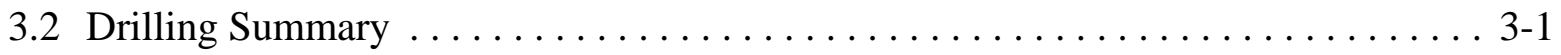

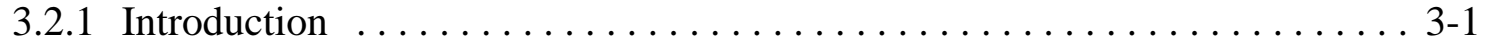

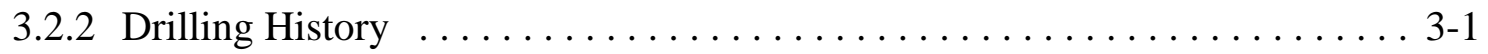

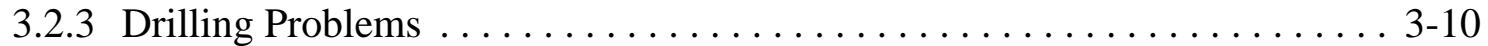

3.2.4 Fluid Management ............................... 3-11

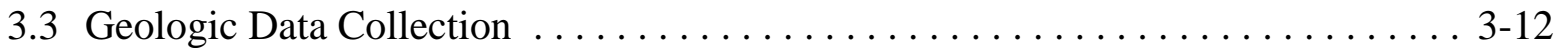

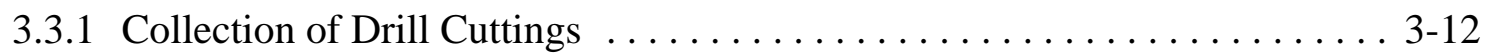

3.3.2 Sidewall Core Samples . . . . . . . . . . . . . . . . . . . . . . . 3-12

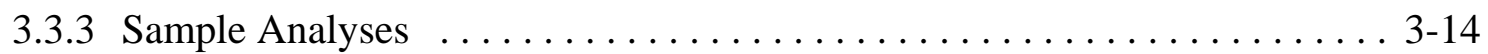

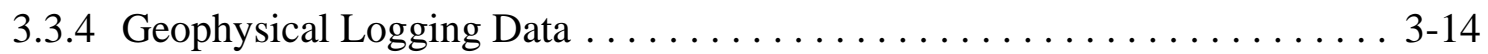

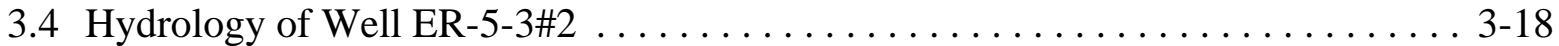

3.4.1 Preliminary Water Level Information $\ldots \ldots \ldots \ldots \ldots \ldots \ldots \ldots \ldots . . .6 \ldots$

3.4.2 Preliminary Water Production Information $\ldots \ldots \ldots \ldots \ldots \ldots \ldots . . .6 .18$

3.4.3 Preliminary Thermal Flow Log Data . .................... 3-18

3.4.4 Preliminary Groundwater Characterization Samples . . . . . . . . . . . . 3-19

3.5 Precompletion and Open-Hole Development . . . . . . . . . . . . . . . . . . . . 3-19

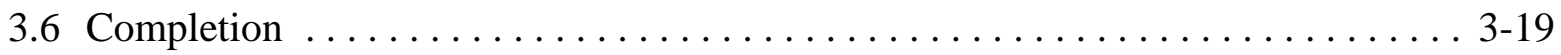

3.6.1 Proposed Completion Design ............................. 3-19

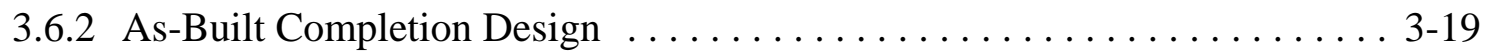

3.6.3 Rationale for Difference Between Actual and Proposed Well Design . . . . 3-23

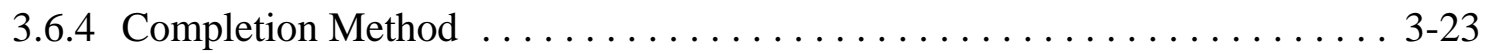

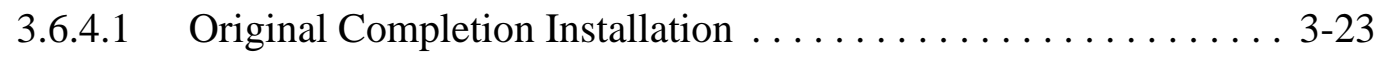

3.6.4.2 Recompletion .......................... 3-24

3.7 Actual Versus Planned Costs and Scheduling for Well ER-5-3\#2 . . . . . . . . . 3-24

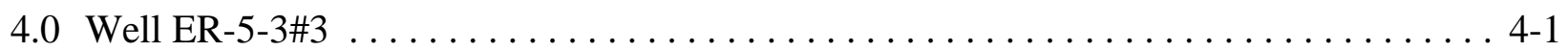

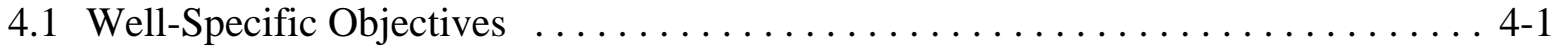




\section{Table of Contents (Continued)}

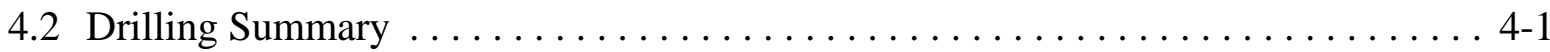

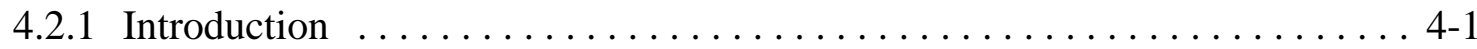

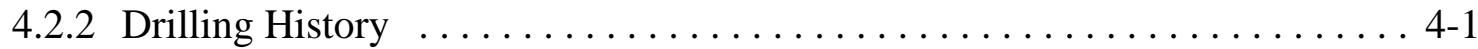

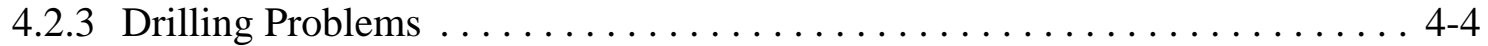

4.2.4 Fluid Management $\ldots \ldots \ldots \ldots \ldots \ldots \ldots \ldots \ldots \ldots \ldots \ldots \ldots, 4,4$

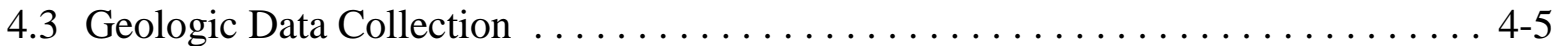

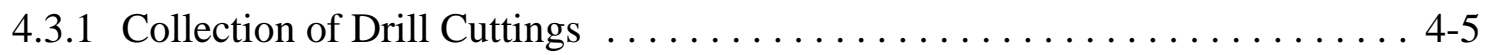

4.3.2 Geophysical Logging Data $\ldots \ldots \ldots \ldots \ldots \ldots \ldots \ldots \ldots \ldots \ldots \ldots \ldots$

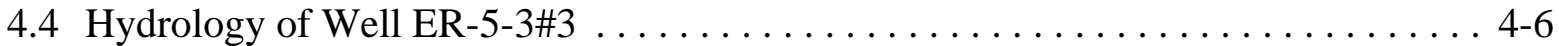

4.4.1 Preliminary Water Level Information $\ldots \ldots \ldots \ldots \ldots \ldots \ldots \ldots \ldots . \ldots \ldots$

4.4.2 Preliminary Water Production Information $\ldots \ldots \ldots \ldots \ldots \ldots \ldots .4 .6$

4.4.3 Preliminary Thermal Flow Log Data $\ldots \ldots \ldots \ldots \ldots \ldots \ldots \ldots .4 .7$

4.4.4 Preliminary Groundwater Characterization Samples ................ 4-7

4.5 Precompletion and Open-Hole Development . . . . . . . . . . . . . . . . 4 4-7

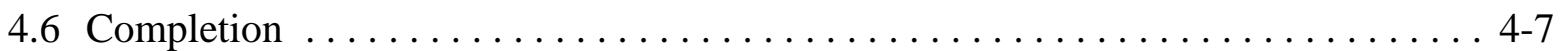

4.6.1 Proposed Completion Design .......................... 4-7

4.6.2 As-Built Completion Design $\ldots \ldots \ldots \ldots \ldots \ldots \ldots \ldots \ldots \ldots \ldots .4 .7$

4.6.3 Rationale for Difference Between Actual and Proposed Well Design . . . . 4-10

4.6.4 Completion Method ............................ 4-10

4.7 Actual Versus Planned Costs and Scheduling for Well ER-5-3\#3 . . . . . . . . . . 4-11

5.0 Geology and Hydrogeology of Well Cluster ER-5-3 $\ldots \ldots \ldots \ldots \ldots \ldots \ldots \ldots$ 5-1

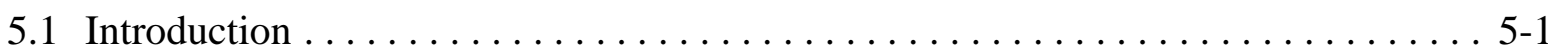

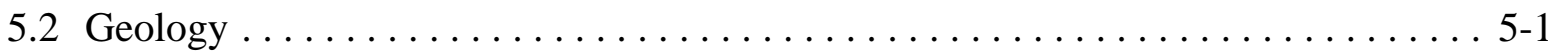

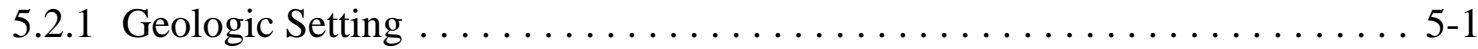

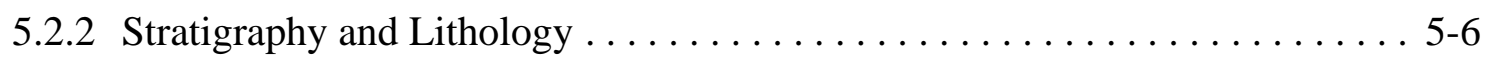

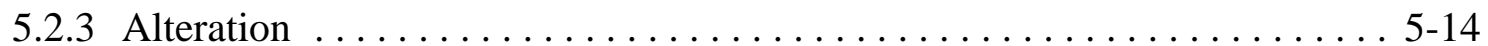

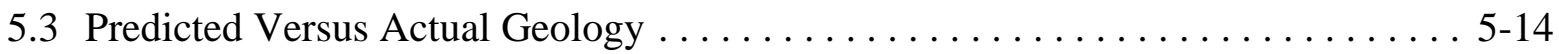

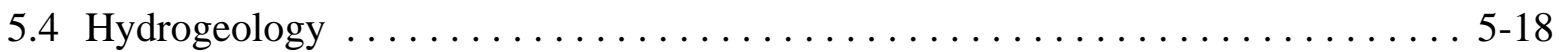

6.0 Summary, Recommendations, and Lessons Learned from Well Cluster ER-5-3 . . . . . 6 6-1

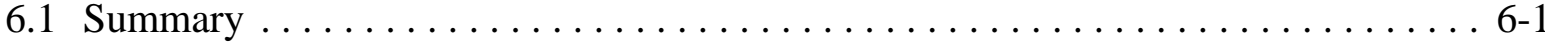

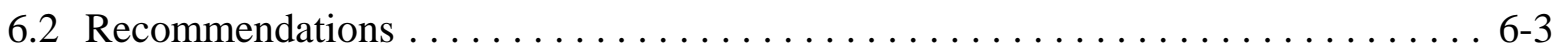

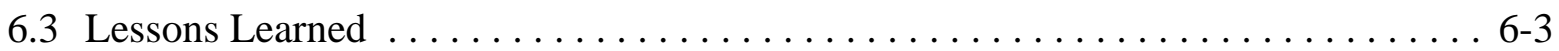

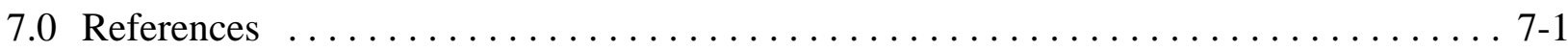


Table of Contents (Continued)

Appendix A - Drilling Data

A-1 Drilling Parameter Logs for Well Cluster ER-5-3

A-2 Tubing and Casing Data for Well Cluster ER-5-3

A-3 Well Cluster ER-5-3 Drilling Fluids and Cement Composition

Appendix B - Well ER-5-3 Fluid Management Data

Appendix C - Preliminary Detailed Lithologic Logs for Well ER-5-3

C-1 Detailed Lithologic Log for Well ER-5-3

C-2 Detailed Lithologic Log for Well ER-5-3\#2

C-3 Detailed Lithologic Log for Well ER-5-3\#3

Appendix D - Geophysical Logs Run in Wells ER-5-3 and ER-5-3\#2

D-1 Geophysical Logs Run in Well ER-5-3

D-2 Geophysical Logs Run in Well ER-5-3\#2

Distribution List 


\section{List of Figures}

Number

Title

Page

1-1 Reference Map Showing Location of Well Cluster ER-5-3 . . . . . . . . . . 1-3

1-2 Drill-Site Configuration for Well Cluster ER-5-3 . . . . . . . . . . . . . 1-8

2-1 Well ER-5-3 Drilling and Completion History $\ldots \ldots \ldots \ldots \ldots \ldots \ldots \ldots \ldots \ldots$

2-2 As-Built Completion Schematic for Well ER-5-3 . . . . . . . . . . . . . . . . 2-20

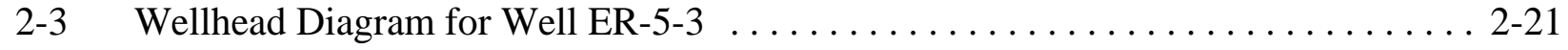

2-4 Planned versus Actual Construction Progress for Well ER-5-3 . . . . . . . . . . 2-27

2-5 Planned versus Actual Cost for Constructing Well ER-5-3 . . . . . . . . . . . 2-28

3-1 Well ER-5-3\#2 Drilling and Completion History $\ldots \ldots \ldots \ldots \ldots \ldots \ldots \ldots \ldots .3$

3-2 As-Built Completion Schematic for Well ER-5-3\#2 . . . . . . . . . . . . . . . . 3-20

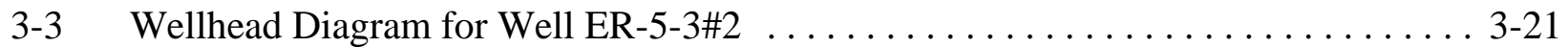

3-4 Planned versus Actual Construction Progress for Well ER-5-3\#2 . . . . . . . . . 3-26

3-5 Planned versus Actual Cost for Constructing Well ER-5-3\#2 . . . . . . . . . . 3-27

4-1 Well ER-5-3\#3 Drilling and Completion History $\ldots \ldots \ldots \ldots \ldots \ldots \ldots \ldots \ldots .4$

4-2 As-Built Completion Schematic for Well ER-5-3\#3 . . . . . . . . . . . . . . 4-8

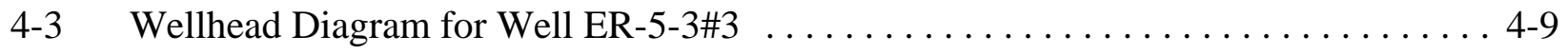

4-4 Planned versus Actual Construction Progress for Well ER-5-3\#3 . . . . . . . . . . 4-12

4-5 Planned versus Actual Cost for Constructing Well ER-5-3\#3 . . . . . . . . . . 4-13

5-1 Surface Geologic Map of the Well ER-5-3 Site $\ldots \ldots \ldots \ldots \ldots \ldots \ldots \ldots \ldots$. . . . .

5-2 Geology and Hydrogeology of Well Cluster ER-5-3 Showing Locations of Slotted Intervals . . . . . . . . . .

5-3 Geologic Cross Section A-A' through Well Cluster ER-5-3 . . . . . . . . . . . 5-9

5-4 Geologic Cross Section B-B' through Well Cluster ER-5-3 . . . . . . . . . . . . . 5-10

5-5 West-northwest to East-southeast Seismic Profile Through Well ER-5-3\#2 . . . . . 5-15

5-6 Predicted and Actual Stratigraphy at Well Cluster ER-5-3 . . . . . . . . . . . . 5-17

5-7 West-East Hydrogeologic Cross Section (A-A’) through Well Cluster ER-5-3 . . . . 5-19

5-8 North-South Hydrogeologic Cross Section (B-B') through Well Cluster ER-5-3 . . 5-20 


\section{List of Tables}

Number

Title

Page

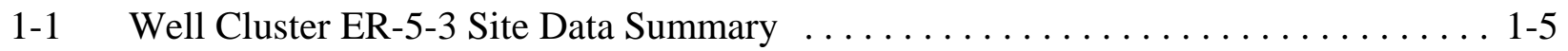

2-1 Abridged Drill Hole Statistics for Well ER-5-3 $\ldots \ldots \ldots \ldots \ldots \ldots \ldots \ldots \ldots .2-5$

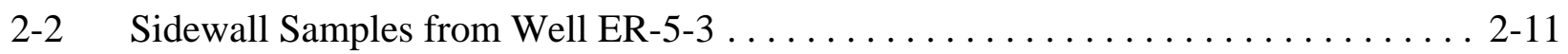

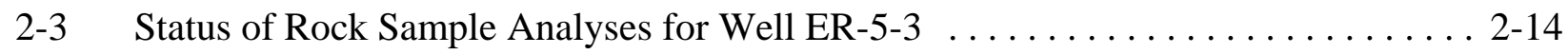

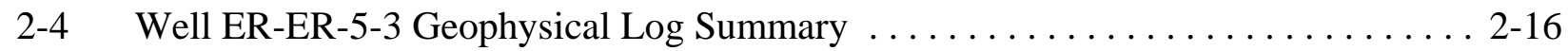

2-5 Well ER-5-3 Completion String Construction Summary $\ldots \ldots \ldots \ldots \ldots \ldots \ldots .2-22$

3-1 Abridged Drill Hole Statistics for Well ER-5-3\#2 $\ldots \ldots \ldots \ldots \ldots \ldots \ldots \ldots \ldots \ldots \ldots \ldots \ldots$

3-2 Sidewall Samples from Well ER-5-3\#2 $\ldots \ldots \ldots \ldots \ldots \ldots \ldots \ldots \ldots \ldots \ldots \ldots \ldots \ldots \ldots \ldots \ldots$

3-3 Status of Rock Sample Analyses for Well ER-5-3\#2 $\ldots \ldots \ldots \ldots \ldots \ldots \ldots \ldots \ldots$ 3-15

3-4 Well ER-ER-5-3\#2 Geophysical Log Summary ..................... 3-16

3-5 Well ER-5-3\#2 Completion String Construction Summary $\ldots \ldots \ldots \ldots \ldots \ldots$ 3-22

4-1 Abridged Drill Hole Statistics for Well ER-5-3\#3 $\ldots \ldots \ldots \ldots \ldots \ldots \ldots \ldots .4$.

4-2 Well ER-5-3\#3 Geophysical Log Summary $\ldots \ldots \ldots \ldots \ldots \ldots \ldots \ldots \ldots . . \ldots \ldots$

4-3 Well ER-5-3\#3 Completion String Construction Summary $\ldots \ldots \ldots \ldots \ldots \ldots .4$. 4 -10

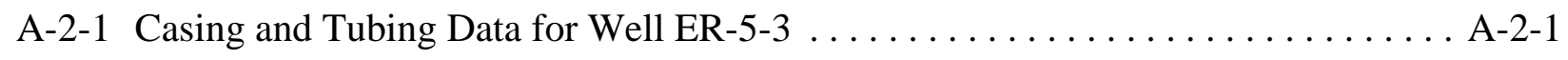

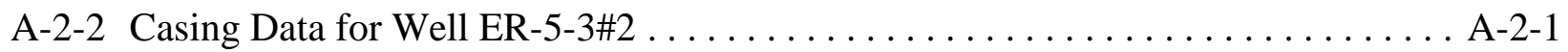

A-2-3 Casing and Tubing Data for Well ER-5-3\#3 $\ldots \ldots \ldots \ldots \ldots \ldots \ldots \ldots \ldots$ A-2-2

A-3-1 Drilling Fluids Used in Well ER-5-3 $\ldots \ldots \ldots \ldots \ldots \ldots \ldots \ldots \ldots \ldots \ldots$ A-3-1

A-3-2 Drilling Fluids Used in Well ER-5-3\#2 $\ldots \ldots \ldots \ldots \ldots \ldots \ldots \ldots \ldots \ldots \ldots$ A-3-1

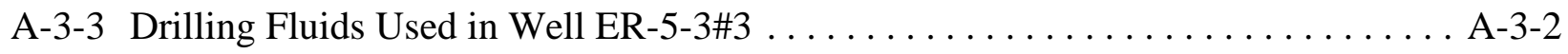

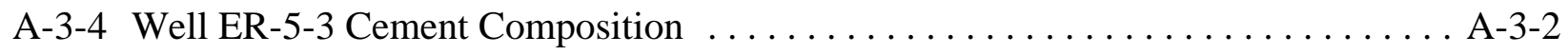

A-3-5 Well ER-5-3\#2 Cement Composition $\ldots \ldots \ldots \ldots \ldots \ldots \ldots \ldots \ldots \ldots \ldots \ldots \ldots \ldots \ldots \ldots \ldots \ldots \ldots$

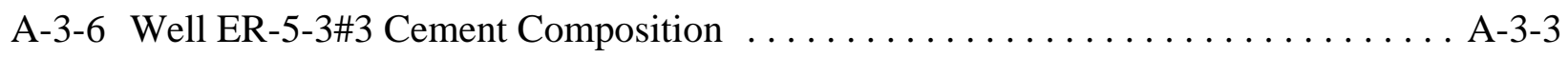

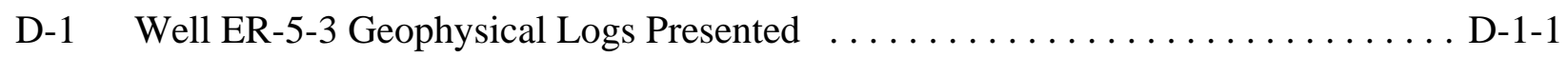

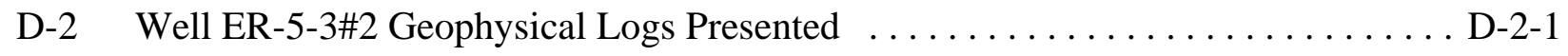




\section{List of Acronyms and Abbreviations}

\begin{tabular}{|c|c|}
\hline BHA & bottom-hole assembly \\
\hline $\mathrm{BN}$ & Bechtel Nevada \\
\hline CC & cubic centimeter(s) \\
\hline $\mathrm{cm}$ & centimeter(s) \\
\hline DOE & U.S. Department of Energy \\
\hline $\mathrm{DOE} / \mathrm{NV}$ & U.S. Department of Energy, Nevada Operations Office \\
\hline DRI & Desert Research Institute \\
\hline $\mathrm{EC}$ & Electrical Conductivity \\
\hline FMP & Fluid Management Plan \\
\hline $\mathrm{ft}$ & foot (feet) \\
\hline gpm & gallons per minute \\
\hline in. & inch(es) \\
\hline IT & IT Corporation \\
\hline $\mathrm{km}$ & kilometer(s) \\
\hline lpm & liters per minute \\
\hline LANL & Los Alamos National Laboratory \\
\hline LCA & lower carbonate aquifer \\
\hline $\mathrm{LiBr}$ & lithium bromide \\
\hline $\mathrm{m}$ & meter(s) \\
\hline $\mathrm{mi}$ & mile(s) \\
\hline Ma & million years ago \\
\hline NAD & North American Datum \\
\hline NNSA/NSO & $\begin{array}{l}\text { U.S. Department of Energy, National Nuclear Security Administration } \\
\text { Nevada Site Office }\end{array}$ \\
\hline NTS & Nevada Test Site \\
\hline SN-JV & Stoller-Navarro Joint Venture \\
\hline TD & total depth \\
\hline TFM & Thermal Flow Meter \\
\hline TWG & Technical Working Group \\
\hline UGTA & Underground Test Area \\
\hline UDI & United Drilling, Inc. \\
\hline USGS & United States Geological Survey \\
\hline
\end{tabular}


This page intentionally left blank. 


\subsection{Introduction}

\subsection{Project Description}

Well Cluster ER-5-3 was drilled for the U.S. Department of Energy (DOE), National Nuclear Security Administration Nevada Site Office (NNSA/NSO; formerly Nevada Operations Office, DOE/NV) in support of the Nevada Environmental Restoration Project at the Nevada Test Site (NTS), Nye County, Nevada. This well cluster was constructed as part of the hydrogeologic investigation program for Frenchman Flat. This program is part of the NNSA/NSO Environmental Restoration Project's Underground Test Area (UGTA) sub-project at the NTS. The goals of the UGTA sub-project include evaluating the nature and extent of contamination in groundwater due to underground nuclear testing, and establishing a long-term groundwater monitoring network. As part of the UGTA sub-project, scientists are developing computer models to predict groundwater flow and contaminant migration within and near the NTS. To build and test these models, it is necessary to collect geologic, geophysical, and hydrologic data from new and existing wells to define groundwater quality, migration pathways, and migration rates.

The goal of constructing, sampling, and hydrogeologic testing at Well Cluster ER-5-3 was to collect subsurface geologic and hydrologic data in a poorly characterized area near a group of underground nuclear test locations in Frenchman Flat. Data from these wells will allow for more accurate modeling of groundwater flow and radionuclide migration in the region. One or more of the wells may also function as long-term monitoring well(s).

Well Cluster ER-5-3 is located in northwestern Area 5 of the NTS near the northern Frenchman Flat underground nuclear test area (Figure 1-1). The well cluster consists of 3 boreholes drilled on the same drill pad. The elevation of the dirt-fill drill pad at the wellheads is 1,016.3 meters $(\mathrm{m})$ (3,334.3 feet [ft]) above mean sea level. The Nevada State plane coordinates and elevation at all 3 wellheads are listed in Table 1-1, along with additional site summary and survey information.

IT Corporation (IT) was the principal environmental contractor for the project, and IT personnel collected geologic and hydrologic data during drilling. The drilling company was United Drilling, Incorporated (UDI), a subcontractor to Bechtel Nevada (BN). Site supervision, engineering, construction, inspection, and geologic support were provided by BN. The roles and responsibilities of these and other contractors involved in the project are described in Contract Number DE-RP-08-95NV11808, and in BN Drilling Work Plans, Number D-002-001.00, 
This page intentionally left blank. 


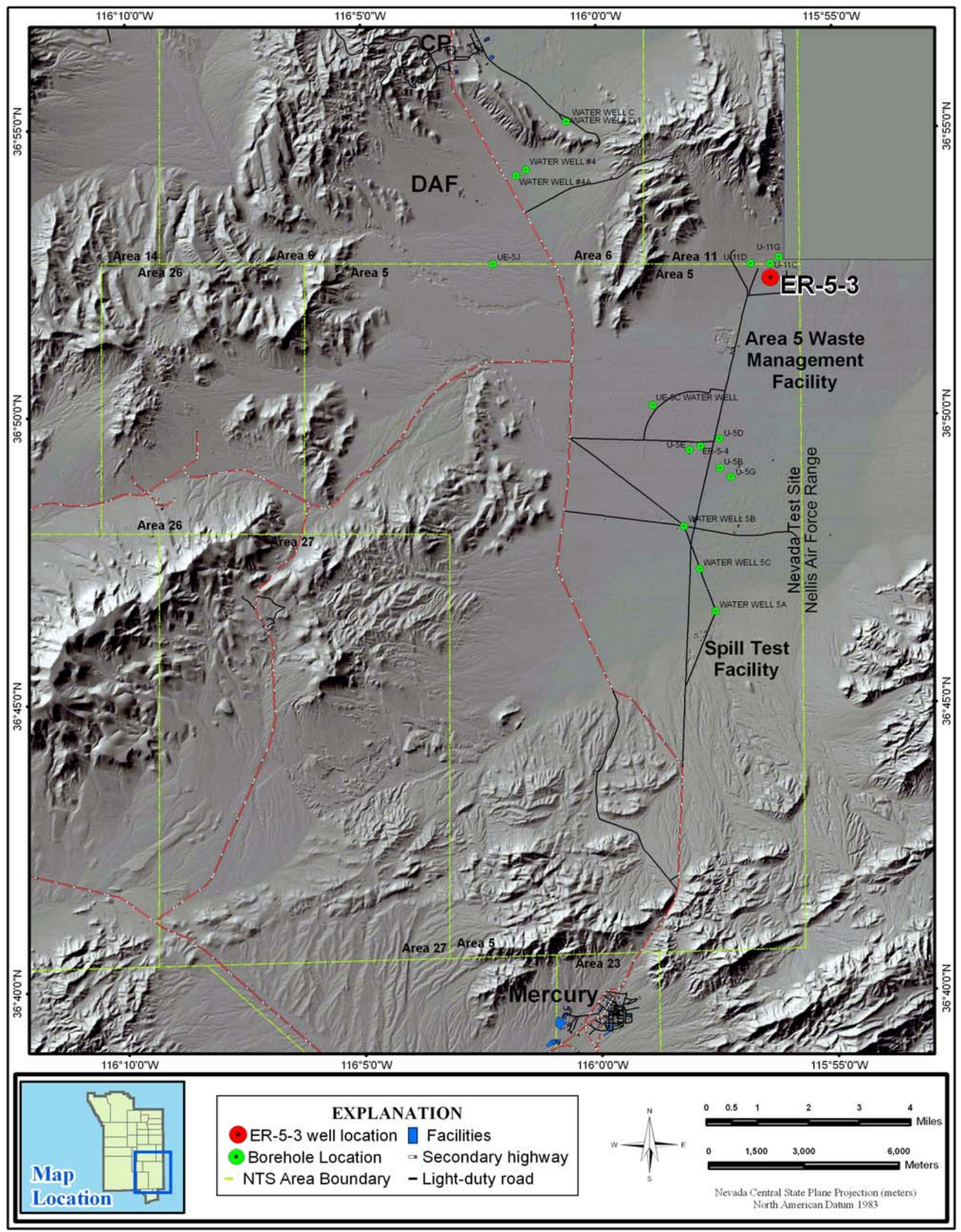

Figure 1-1

Reference Map Showing Location of Well Cluster ER-5-3 
This page intentionally left blank. 
Table 1-1

Well Cluster ER-5-3 Site Data Summary

\begin{tabular}{|c|c|c|c|c|}
\hline \multicolumn{2}{|c|}{$\begin{array}{l}\text { Well Designation } \\
\text { (Date Completed) }\end{array}$} & $\begin{array}{c}\text { ER-5-3 } \\
\text { (March 14, 2000) }\end{array}$ & $\begin{array}{c}\text { ER-5-3\#2 } \\
\text { (May 19, 2000) } \\
\text { (recompleted: } \\
\text { March 20, 2001) }\end{array}$ & $\begin{array}{c}\text { ER-5-3\#3 } \\
\text { (February 5, 2001) }\end{array}$ \\
\hline \multirow{3}{*}{$\begin{array}{c}\text { Site } \\
\text { Coordinates }^{a}\end{array}$} & $\begin{array}{l}\text { Central Nevada State } \\
\text { Planar (NAD 83) }\end{array}$ & $\begin{array}{lc}N & 6,235,787.4 \mathrm{~m} \\
\mathrm{E} & 564,885.8 \mathrm{~m} \\
& \\
\mathrm{~N} & 20,458,579.3 \mathrm{ft} \\
\mathrm{E} & 1,853,296.1 \mathrm{ft}\end{array}$ & $\begin{array}{lc}N & 6,235,789.9 \mathrm{~m} \\
\mathrm{E} & 564,855.2 \mathrm{~m} \\
& \\
\mathrm{~N} & 20,458,587.4 \mathrm{ft} \\
\mathrm{E} & 1,853,195.9 \mathrm{ft}\end{array}$ & $\begin{array}{lc}\mathrm{N} & 6,235,814.9 \mathrm{~m} \\
\mathrm{E} & 564,872.6 \mathrm{~m} \\
& \\
\mathrm{~N} & 20,458,669.3 \mathrm{ft} \\
\mathrm{E} & 1,853,252.8 \mathrm{ft}\end{array}$ \\
\hline & $\begin{array}{l}\text { Central Nevada State } \\
\text { Planar (NAD 27) (feet) }\end{array}$ & $\begin{array}{ll}\text { N } 773,577.8 \\
\text { E } 713,137.0\end{array}$ & $\begin{array}{l}\text { N } 773,586.1 \\
\text { E } 713,036.7\end{array}$ & $\begin{array}{l}\text { N } 773,668.0 \\
\text { E } 713,093.7\end{array}$ \\
\hline & $\begin{array}{l}\text { Universal Transverse } \\
\text { Mercator (Zone 11) } \\
\text { (NAD 83) (meters) }\end{array}$ & $\begin{array}{lc}N & 4,081,314.6 \\
E & 594,575.3\end{array}$ & $\begin{array}{lc}N & 4,081,317.0 \\
E & 594,544.7\end{array}$ & $\begin{array}{lc}N & 4,081,342.0 \\
E & 594,562.0\end{array}$ \\
\hline \multicolumn{2}{|c|}{ Surface Elevation ${ }^{\mathrm{b}}$} & $1,016.3 \mathrm{~m}(3,334.3 \mathrm{ft})$ & $1,016.3 \mathrm{~m} \mathrm{(3,334.3 \textrm {ft } )}$ & $1,016.4 \mathrm{~m}(3,334.6 \mathrm{ft})$ \\
\hline \multicolumn{2}{|c|}{ Drilled Depth } & $794.3 \mathrm{~m}(2,606 \mathrm{ft})$ & $1,732.2 \mathrm{~m}(5,683 \mathrm{ft})$ & $548.6 \mathrm{~m}(1,800 \mathrm{ft})$ \\
\hline \multicolumn{2}{|c|}{$\begin{array}{l}\text { Fluid-Level Depth } \\
\text { (Date measured }^{\text {C) }}\end{array}$} & $\begin{array}{l}282.6 \mathrm{~m}(927 \mathrm{ft}) \\
\text { (April 14, 2000) }\end{array}$ & $\begin{array}{c}282.6 \mathrm{~m}(927 \mathrm{ft}) \\
(\text { April } 5,2000)\end{array}$ & $\begin{array}{c}282.7 \mathrm{~m}(927.6 \mathrm{ft}) \\
\text { (February 21, 2001) }\end{array}$ \\
\hline \multicolumn{2}{|c|}{ Fluid-Level Elevation } & $733.8 \mathrm{~m}(2,407.3 \mathrm{ft})$ & $733.8 \mathrm{~m}(2,407.3 \mathrm{ft})$ & $733.7 \mathrm{~m}(2,407.0 \mathrm{ft})$ \\
\hline
\end{tabular}

\footnotetext{
a Measurement made by BN Survey. NAD = North American Datum

b Measurement made by BN Survey. Elevation at top of construction pad. National Geodetic Vertical Datum, 1929.

c Measured by IT before well development at Wells ER-5-3 and ER-5-3\#3. Measurement made in Well ER-5-3\#2 when hole was at depth of $622.7 \mathrm{~m}$ (2,043 ft) (IT, 2000b, 2001b).
}

Numbers D-003-001.00 and D-003-001.01, and Number D-001.003.01 (BN, 2000a, b; BN, 2001a, c). The UGTA Technical Working Group (TWG), a committee of scientists and engineers comprising NNSA/NSO, Lawrence Livermore National Laboratory, Los Alamos National Laboratory (LANL), and contractor personnel, provided additional technical advice during drilling, design, and construction of the well. See Frenchman Flat Hydrogeologic Investigation Wells Drilling and Completion Criteria, Revisions 0 and 1. (IT, 2000a, 2001a) for descriptions of the general plan and goals of the Well Cluster ER-5-3 project, as well as specific goals for each planned well.

General guidelines for managing fluids used and generated during drilling, completion, and testing of UGTA wells are provided in the UGTA Fluid Management Plan (FMP) (DOE, 1999), an attachment to the latest revision of the UGTA Waste Management Plan (DOE, 1996). Estimates of production of fluid and drill cuttings for the Well ER-5-3 cluster are given in 
Appendix C of the drilling and completion criteria document for the project (IT, 2000a), along with sampling requirements and contingency plans for management of any hazardous waste produced. All activities for Wells ER-5-3 and ER-5-3\#2 were conducted according to the Nevada Environmental Restoration Project Health and Safety Plan, Revision 3 (DOE/NV, 1998), and the Site Specific Health and Safety Plan for Western Pahute Mesa - Oasis Valley Investigation Wells, with technical field changes Numbers 1 and 2 (BN, 1999). All activities associated with construction of Well ER-5-3\#3 were conducted according to the UGTA Project Health and Safety Plan (BN, 2001b).

This report presents construction data and summarizes scientific data gathered during drilling and the installation of the completion strings for all 3 wells, but does not cover subsequent hydrologic sampling and testing. Well data reports prepared by IT (2000b, 2001b) contain additional information on fluid management, waste management, and environmental compliance. Information on well development, aquifer testing, and groundwater analytical sampling will be compiled and disseminated separately.

\subsection{Objectives}

The primary purpose of constructing Well Cluster ER-5-3 was to obtain information that will help characterize the hydrogeology of northern Frenchman Flat. Scientific objectives, as discussed in the drilling criteria documents (IT, 2000a, 2001a), include the following:

- Validate the current hydrostratigraphic framework model for the northern Frenchman Flat area, including determining the locations of the tops of the hydrostratigraphic units of this area.

- Determine water levels to refine knowledge of the local water table.

- Obtain data concerning variations in the physical character of the alluvial aquifer.

- Obtain samples for detailed mineralogical analyses that will aid in determining the vertical distribution of reactive minerals such as zeolites and clays in the alluvial and volcanic rocks of Frenchman Flat.

- Verify whether the tuff confining unit is present and obtain data on its geologic and hydrologic properties.

- Obtain velocity data and geological control to aid interpretation of the 3-dimensional (3-D) seismic reflection survey conducted in Frenchman Flat in 2001.

- Obtain representative aqueous geochemistry samples at the water table, near the base of the alluvial section, and from the lower carbonate aquifer. 
- Obtain hydraulic data to determine vertical head distribution/vertical hydraulic gradient within the alluvial aquifer and between the various hydrostratigraphic units.

- Obtain vertical and horizontal conductivity measurements.

- Obtain hydrogeologic data to address whether a hydrologic "shortcut" such as a fault, might exist from sources in the alluvial aquifer to the lower carbonate aquifer.

Some of these objectives will not be met until additional work, outside the scope of this report, is completed, including installing pumps and conducting hydraulic testing, and analyzing geologic and hydrologic data from these wells and other data for the Frenchman Flat area. Objectives for the individual wells of the cluster are listed in the well-specific sections of this report

\subsection{Project Summary}

This section summarizes the construction operations and geology encountered at Well Cluster ER-5-3; the details are provided in Sections 2 through 8 of this report. Three separate boreholes were drilled at this site in the attempt to penetrate saturated alluvium, the volcanic aquifer, the tuff confining unit, and to reach total depth (TD) in the lower carbonate aquifer. Because of borehole instability problems during drilling of the first borehole, Well ER-5-3, it was terminated in the tuff confining unit before reaching the planned depth of 1,158.2 m (3,800 ft). Well ER-5-3\#2 was then drilled to the depth of 1,732.2 m (5,683.4 ft) within the

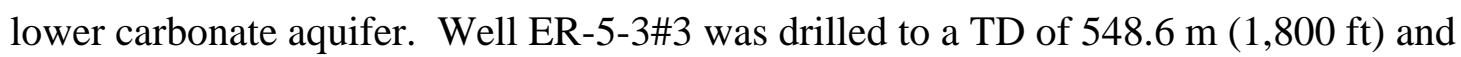
completed in the saturated alluvium. The drill pad was originally constructed to accommodate 2 boreholes and included 2 "UGTA standard” unlined sumps; the pad was later extended to accommodate the third borehole (Figure 1-2).

Composite drill cuttings were collected every $3 \mathrm{~m}(10 \mathrm{ft})$ below the conductor casing during drilling of all 3 boreholes. A total of 120 sidewall samples was taken in Wells ER-5-3 and ER-5-3\#2 at various depths between 91.4 and 1,443.8 m (300 and 4,737 ft). No sidewall samples were collected from Well ER-5-3\#3. Open-hole geophysical logging was conducted at various stages of drilling of Wells ER-5-3 and ER-5-3\#2 to help verify the geology and characterize the hydrology of the rocks; some logs also aided in the construction of the well by indicating borehole volume and condition, cement location, and borehole deviation. In Well ER-5-3\#3 geophysical logging was done only to monitor emplacement of stemming materials and to measure borehole deviation. 


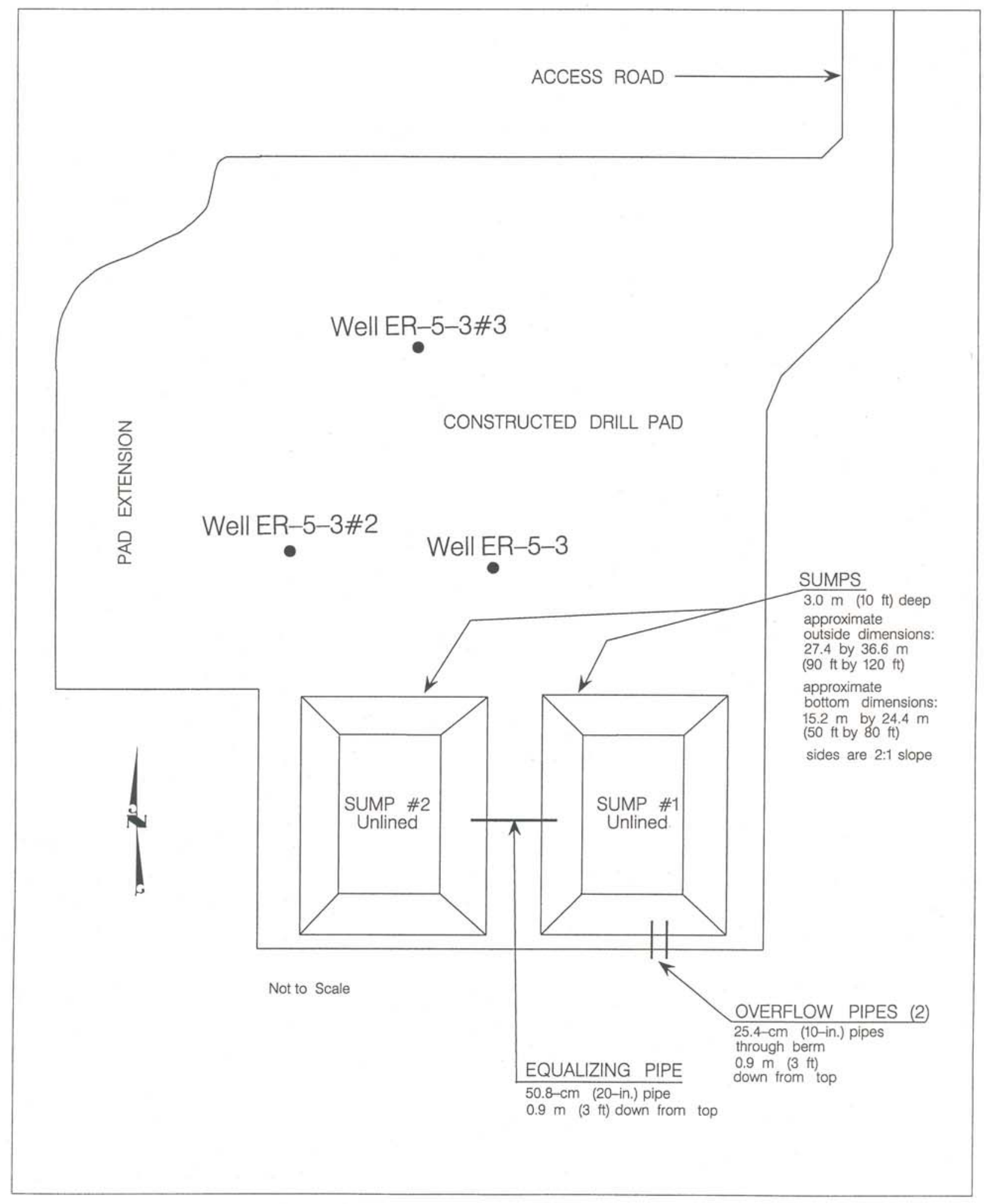

Figure 1-2

Drill Site Configuration for Well Cluster ER-5-3 
No radionuclides above background levels were encountered during drilling of Well Cluster ER-5-3.

The wells penetrated Quaternary/Tertiary alluvium to the depth of $622.4 \mathrm{~m}$ (2,042 ft), and an 8.5-m (28-ft) thick basalt was encountered within the alluvium. Tertiary tuff was penetrated to the depth of approximately 1,425.9 m (4,678 ft), where the top of the lower carbonate aquifer was tagged in Well ER-5-3\#2.

\subsubsection{Well ER-5-3}

The conductor hole was constructed by augering a 121.9-centimeter (cm) (48-inch [in.])

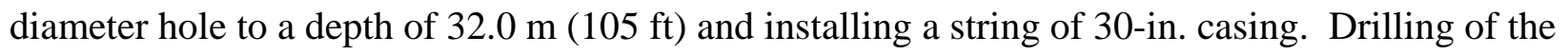
main hole with an 181/2-in. rotary bit began on February 22, 2000. The drill fluid was an airwater-foam mix (“air-foam”) with a polymer additive as required, in conventional circulation. A

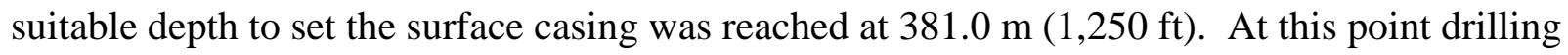
was suspended for geophysical logging, and then a $27 / 8$-in. piezometer string (\#1) was landed at the depth of $367.9 \mathrm{~m}(1,236.7 \mathrm{ft})$. The 13\% $(1,229.6 \mathrm{ft})$, adjacent to the piezometer string and extending approximately $92.3 \mathrm{~m}$ (303 ft) below the static water level, on February 26, 2000. Drilling continued with air-foam/polymer and a 121/4-in. bit to a TD of $794.3 \mathrm{~m}$ (2,606 ft), at which point the decision was made to terminate drilling, on March 7, 2000, due to problems with borehole stability. This depth is approximately $379.2 \mathrm{~m}(1,244 \mathrm{ft})$ short of the planned depth for this well.

Water production was first noted at the depth of $292.6 \mathrm{~m}(960 \mathrm{ft})$, and reached a maximum of approximately 8,325 liters per minute (lpm) (2,200 gallons per minute [gpm]) in the welded Rainier Mesa Tuff near the bottom of the borehole. About a month after completion of the well, the fluid level was tagged at the depth of $282.5 \mathrm{~m}(927 \mathrm{ft})$.

Piezometer String \#2 and the production casing were installed on March 13 to 16, 2000. The piezometer string consists of $27 / 8$-in. stainless-steel tubing and was landed at the depth of $674.2 \mathrm{~m}(2,212.0 \mathrm{ft})$. A string of 51/2-in. stainless-steel production casing was landed adjacent to the piezometer at the depth of $777.6 \mathrm{~m}(2,551.3 \mathrm{ft})$. This string has 2 slotted intervals. The lower slotted section is open to the welded Rainier Mesa Tuff at 737.8 to $777.0 \mathrm{~m}$ (2,420.5 to $2,549.1 \mathrm{ft}$ ), and the upper slotted section is open to the saturated alluvium at 451.0 to $529.5 \mathrm{~m}$ $(1,479.7$ to $1,737.1 \mathrm{ft})$. A string of $75 / 8$-in. carbon-steel casing with an internal epoxy coating extends from the top of the $5 \frac{1}{2} 2$-in. casing to the ground surface. The completion string was gravel-packed across the slotted intervals and the remaining annular space was filled with gravel, 
sand, and cement to the depth of $271.3 \mathrm{~m}$ (890 ft) on March 16, 2001. No pump was installed at the time of completion, but will be inserted as needed for hydrologic sampling and testing activities.

\subsubsection{Well ER-5-3\#2}

The conductor hole was constructed by augering a 121.9-cm (48-in.) diameter hole to a depth of $36.6 \mathrm{~m} \mathrm{(120} \mathrm{ft)} \mathrm{and} \mathrm{installing} \mathrm{a} \mathrm{string} \mathrm{of} \mathrm{30-in.} \mathrm{casing.} \mathrm{Drilling} \mathrm{of} \mathrm{the} \mathrm{surface} \mathrm{hole} \mathrm{with} \mathrm{a}$ 171/2-in. rotary bit began on March 23, 2000, and the drill fluid was air-foam/polymer in conventional circulation. Due to borehole instability problems, after the 44.5-cm (17.5-in.) hole reached a depth of $622.7 \mathrm{~m}(2,043 \mathrm{ft})$, the hole was opened to the diameter of $66.0 \mathrm{~cm}(26 \mathrm{in}$.) to permit installation of a 20-in. surface casing, which was set at the depth of $613.8 \mathrm{~m}(2,013.8 \mathrm{ft})$. Drilling then continued with the 171/2-in. bit to the depth of $856.2 \mathrm{~m}(2,809 \mathrm{ft})$, though a short interval had to be cemented and re-drilled to stabilize a sloughing zone. A string of 13\%/8-in. casing was installed at the depth of $849.0 \mathrm{~m}$ (2,785.5 ft), then drilling resumed with a 121/4-in. bit to the TD of 1,732.3 $\mathrm{m}(5,683 \mathrm{ft})$. Borehole instability problems continued until the borehole reached the dolomite at $1,425.9 \mathrm{~m}(4,678 \mathrm{ft})$.

Water production was first noted at the depth of $284.7 \mathrm{~m}$ (934 ft). A fluid level of $282.5 \mathrm{~m}$ $(927 \mathrm{ft})$ was determined from a camera run when the hole had been drilled to the depth of $622.7 \mathrm{~m}(2,043 \mathrm{ft})$.

The planned installation of a piezometer string in the alluvial section was prevented by borehole instability problems. A string of 51/2-in. stainless-steel production casing was landed at the depth of 1,496.0 $\mathrm{m}$ (4,908.2 ft). The string has 1 slotted interval that spans the contact between the tuff and the dolomite. During recompletion activities conducted in March 2001, the upper slots at $1,390.9$ to $1,426.5 \mathrm{~m}(4,563.3$ to $4,608.0 \mathrm{ft})$ were cemented to prevent communication with the tuff. The lower slots at $1,426.5$ to $1,495.4 \mathrm{~m}(4,608.0$ to $4,906.1 \mathrm{ft})$ are open to dolomite. The $75 / 8$-in. carbon-steel casing that extends from the top of the $51 / 2$-in. casing to the ground surface has an internal epoxy coating from its connection to the 51/2-in. casing to $75.5 \mathrm{~m}$ (247.9 ft). No gravel-packing or sand intervals were installed in the well. No pump was installed at the time of recompletion, but will be inserted as needed for hydrologic sampling and testing activities.

\subsubsection{Well ER-5-3\#3}

The conductor hole was constructed by augering a 66.0-cm (26-in.) diameter hole to a depth of $36.6 \mathrm{~m} \mathrm{(120} \mathrm{ft)} \mathrm{and} \mathrm{installing} \mathrm{a} \mathrm{string} \mathrm{of} \mathrm{16-in.} \mathrm{casing.} \mathrm{Drilling} \mathrm{of} \mathrm{the} \mathrm{main} \mathrm{hole} \mathrm{with} \mathrm{a} \mathrm{97/8-in.}$ rotary bit began on January 31, 2001, and drilling advanced with no problems to the TD of 
$548.6 \mathrm{~m}(1,800 \mathrm{ft})$ in alluvium on February 3, 2001. Water production was first noted at the depth of about $248.4 \mathrm{~m}$ (815 ft), just above a basalt layer within the alluvium. The fluid level was tagged at the depth of $282.6 \mathrm{~m}$ (927 ft) on February 5, 2001.

A string of $27 / 8$-in. stainless-steel tubing was set at the depth of $531.9 \mathrm{~m}(1,745.0 \mathrm{ft})$. The tubing is slotted in the interval 454.8 to $531.6 \mathrm{~m}$ (1,492.0 to $1,744.0 \mathrm{ft})$, and the gravel pack was placed on $1.5 \mathrm{~m}$ ( $5 \mathrm{ft}$ ) of fill, from the depth of 443.8 to $547.1 \mathrm{~m} \mathrm{(1,456}$ to $1,795 \mathrm{ft})$. The gravel pack was sealed with sand and cement to the depth of 250.9 m (823 ft) on February 6, 2001.

\subsection{Project Director}

Inquiries concerning Well Cluster ER-5-3 should be directed to the UGTA Federal Project Director at:

U.S. Department of Energy

National Nuclear Security Administration

Nevada Site Office

Environmental Restoration Project

Post Office Box 98518

Las Vegas, Nevada 89193-8518 
This page intentionally left blank. 


\subsection{Well ER-5-3}

This section contains detailed descriptions of the drilling process and fluid management issues, geologic data collection, and completion information for Well ER-5-3, the first borehole drilled in this cluster.

\subsection{Well-Specific Objectives}

The scientific objectives for Well Cluster ER-5-3 listed in Section 1.2 of this report apply to Well ER-5-3. Interpretations based on geologic samples, geophysical logging data, hydrologic data, and water samples from this well will be used to accomplish these objectives. Well ER-5-3 was planned to be drilled to the depth of approximately 1,173.5 $\mathrm{m}(3,850 \mathrm{ft})$, with the intention of drilling into the Paleozoic carbonate rocks of the lower carbonate aquifer.

\subsection{Drilling Summary}

This section contains detailed descriptions of the drilling process and fluid management issues.

\subsubsection{Introduction}

The general drilling requirements for construction of Well ER-5-3 are given in Frenchman Flat Hydrogeologic Investigation Wells Drilling and Completion Criteria, Revisions 0 and 1 (IT, 2000a, 2001a). Specific requirements for Well Cluster ER-5-3 were outlined in Drilling Work Plan Number D-002-001.00 (BN, 2000a). The following information was compiled primarily from BN daily drilling reports. Figure 2-1 is a chart of the drilling and completion history for Well ER-5-3. A summary of drilling statistics for the well is given in Table 2-1.

\subsubsection{Drilling History}

Field operations at Well ER-5-3 began on February 9, 2000, with the augering of a 121.9-cm (48-in.) conductor hole by a BN crew. Some sloughing occurred, so the drillers opened the hole

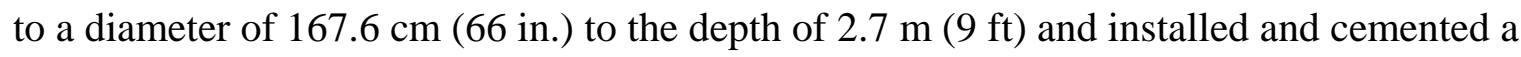
section of 66-in. casing. Drilling of the 121.9-cm (48-in.) hole then continued to the depth of

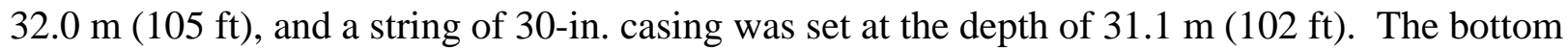
of the conductor casing was cemented inside, and the annulus was cemented to ground level on February 11, 2000.

The UDI crews rigged up the Wilson Mogul 42B rig on February 7-20, 2000, and tagged cement at the depth of $29.9 \mathrm{~m}$ (98 ft). Drilling resumed through cement with a center-punch assembly 
This page intentionally left blank. 


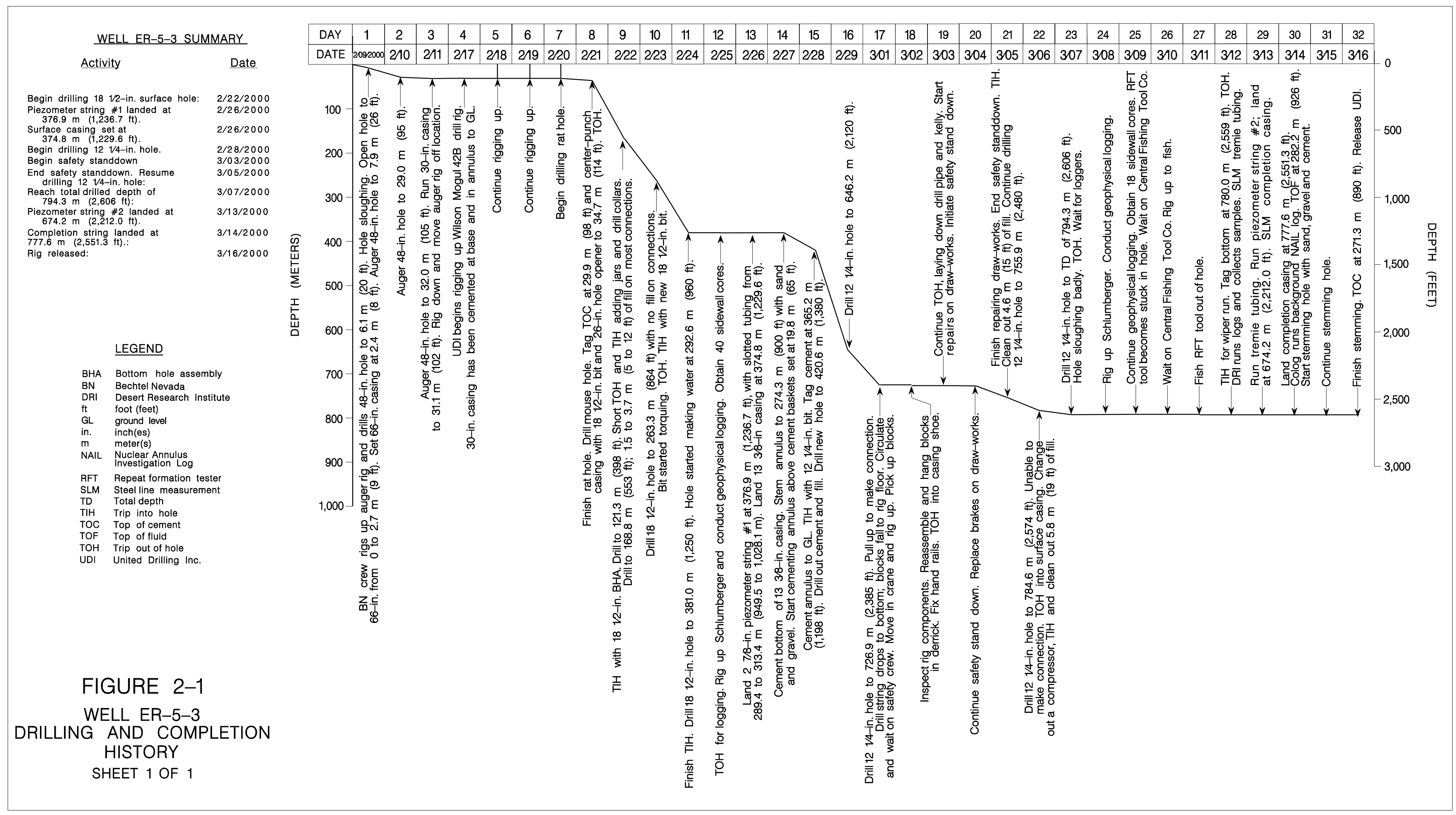


This page intentionally left blank. 
Table 2-1

Abridged Drill Hole Statistics for Well ER-5-3

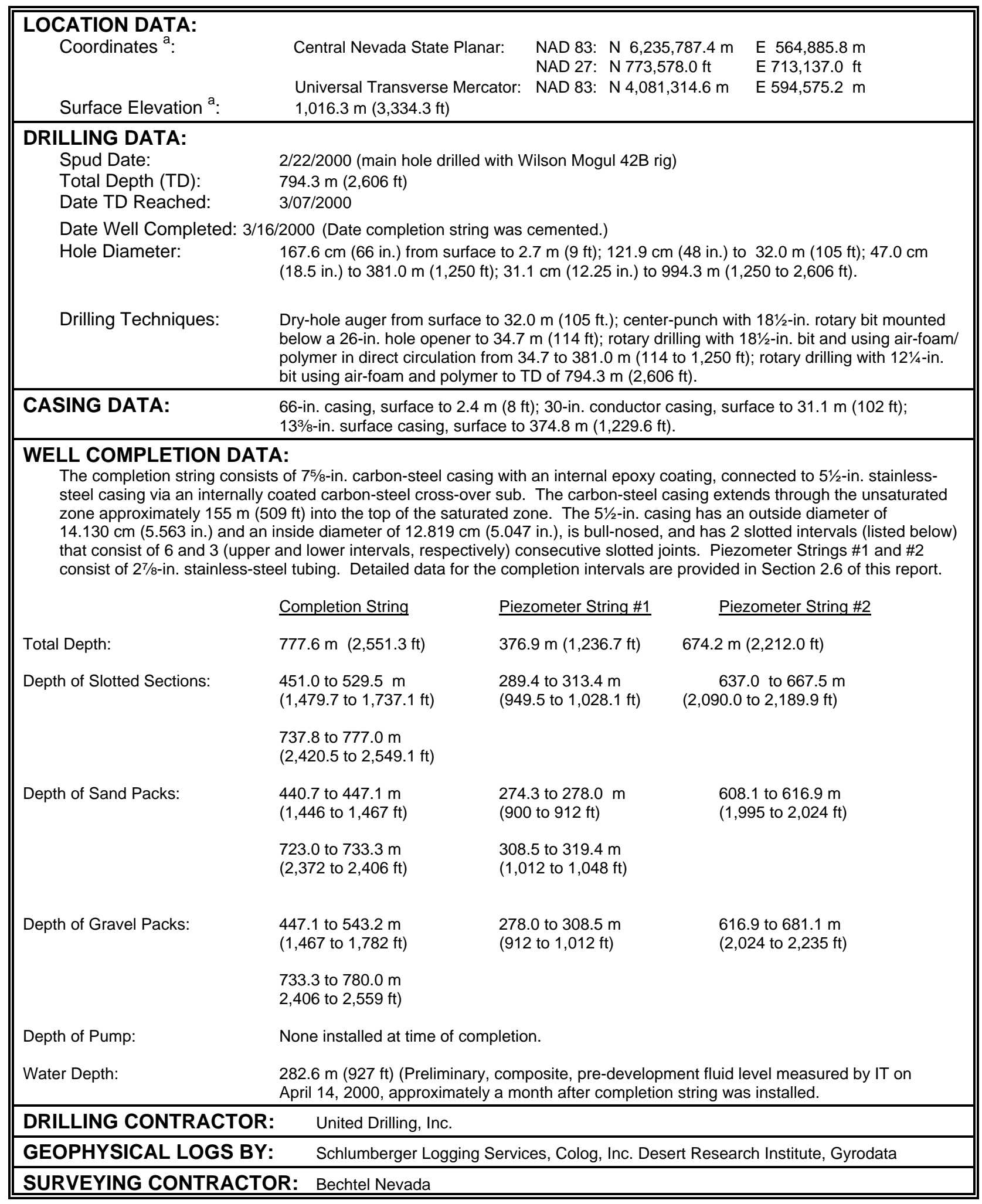

a As-built coordinates and elevation measured by BN Survey. Elevation of ground level at collar based on 1929 National Geodetic Vertical Datum. 
consisting of a 181/2-in. rotary bit mounted below a 26-in. hole opener, using air-foam drilling fluid in conventional circulation. When the 18/2/2-in. bit reached a depth of $34.7 \mathrm{~m}$ (114 ft) and the 26-in. hole opener had reached the top of cement inside the casing, the hole opener was replaced with a bottom-hole assembly (BHA) with a 181/2-in. tricone bit, and drilling of the surface hole began February 22, 2000. A polymer additive was added to the air-foam injection mix beginning at a depth of $45.7 \mathrm{~m}(150 \mathrm{ft})$.

The drilling plan called for installation of the surface casing at the depth of $381.0 \mathrm{~m}(1,250 \mathrm{ft})$, approximately $91.4 \mathrm{~m}$ (300 ft) below the expected depth of the static water level. This depth was reached on February 24, 2000, after 1 stop for a bit change at the depth of $263.3 \mathrm{~m}$ (864 ft). Detectable water production had started when the hole reached the depth of about $292.6 \mathrm{~m}$ (960 ft), and the hole was producing water at an estimated rate of $341 \mathrm{lpm}(90 \mathrm{gpm})$ when drilling was stopped to set the casing (IT, 2000b).

The drillers pulled the drill string off the bottom and waited about 30 minutes before tagging

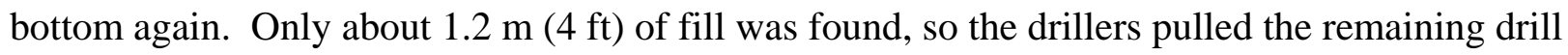
string from the hole, and drilling activity was suspended for 16 hours for geophysical logging, prior to installation of the surface casing (see Section 2.3.4).

The drillers landed the slotted 27/8-in. piezometer string \#1 at the depth of $367.9 \mathrm{~m}(1,236.7 \mathrm{ft})$, and then a casing subcontractor landed a string of $133 / 8$-in. casing adjacent to the piezometer string (see the detailed description of the monitoring strings installed in this well in Section 2.6). The 133/8-in. casing has ribbon stabilizers (centralizers) installed above the guide shoe, at the middle and top of the first joint, and at the top of the second joint. A stab-in float collar was installed between the first and second joints, and 2 metal-petal cement baskets are located at $19.8 \mathrm{~m}$ ( $65 \mathrm{ft}$ ) below ground level. Some tight spots were encountered during installation of the casing, and the casing became lodged at the depth of $136.2 \mathrm{~m}$ (447 ft). The crew used water to wash the casing down past this tight spot and landed it at the depth of $374.8 \mathrm{~m}(1,229.6 \mathrm{ft})$ on February 26, 2000.

In preparation for cementing of the surface casing, the stab-in sub was seated in the float shoe, and the seal was checked by pumping air down the drill pipe. Pre-flush clear water was pumped down the casing and the annulus prior to cementing. Type II cement was pumped inside the casing through the stab-in sub, followed by water to displace the cement into the annulus. The top of cement in the annulus was later determined from geophysical logs to be at the depth of approximately $319.4 \mathrm{~m}$ (1,048 ft). After the drill pipe was pulled from the hole, layers of sand 
and gravel were emplaced on top of the cement in the annulus via a tremie line, to the final depth of $274.3 \mathrm{~m}(900 \mathrm{ft}$ ) (see the detailed description of the gravel-packing process for piezometer strings installed in this well in Section 2.6). A mix of gypsum cement and neat cement was dropped on the cement baskets to seal the remaining annulus to ground level. Cementing of the surface casing was completed on February 28, 2000. The top of cement inside the surface casing was tagged at $365.2 \mathrm{~m}$ (1,198 ft) when the BHA was tripped back into the hole.

Drilling resumed with a 121/4-in. bit. Water production began to increase, reaching about 1,892 lpm (500 gpm) in the welded Ammonia Tanks Tuff encountered at the depth of $622.4 \mathrm{~m}$ $(2,042 \mathrm{ft})$. Drilling continued with no problems to the depth of $726.9 \mathrm{~m}(2,385 \mathrm{ft})$, on March 1, 2000. At that point, as the driller was preparing to add joint of drill pipe, he lost control of the drill string, and it dropped to the bottom of the hole. The traveling blocks on the rig hoist fell to the rig floor. There were no injuries, but drilling was stopped so that the rig draw-works could be repaired. On March 3, 2000, a safety stand-down was initiated to investigate this incident and complete repairs and evaluation of the rig. Drilling resumed on March 5, 2000, and continued to the depth of $784.6 \mathrm{~m}$ (2,574 ft). Water production had increased to about 8,325 lpm (2,200 gpm), and drilling was stopped for 18 hours to add another compressor. The new compressor was delivered and tested on March 6, 2000, then drilling continued to the depth of $794.3 \mathrm{~m}(2,606 \mathrm{ft})$, where increasing sloughing of material from the borehole wall prompted the decision to terminate drilling on March 7, 2000.

The geophysical logging crew arrived on March 8, 2000, and logged the lower, open portion of the borehole. One of the logging tools became stuck in the hole on March 9, 2000, and a “fishing” service was called out to remove it. The tool was recovered on March 11, 2000. The drill crew made a "wiper run” to verify borehole conditions, then supported running of flow logs and collection of fluid samples from the borehole.

Next, the UDI crew inserted a tremie line and landed the slotted $27 / 8$-in. piezometer string \#2 at the depth of $674.2 \mathrm{~m}(2,212.0 \mathrm{ft})$ on March 13, 2000. The casing subcontractor then landed the production casing at the depth of $777.6 \mathrm{~m}(2,551.3 \mathrm{ft})$. Stemming of the annulus of the well through the tremie line began on March 14, 2000; the UDI crew was released after stemming was completed on March 16, 2000.

The TD was reached approximately $379.2 \mathrm{~m}(1,244 \mathrm{ft})$ short of the planned depth of 1,173.5 $\mathrm{m}$ $(3,850 \mathrm{ft})$. The TWG determined that because the next well in this cluster (Well ER-5-3\#2) was 
planned to reach at least the depth originally planned for Well ER-5-3, it was not necessary to risk losing this hole in the effort to deepen it.

The directional survey run in the well on February 15, 2001, indicates that at the lowest surveyed depth of $77.3 \mathrm{~m}$ (2,537 ft) the hole had drifted $14.6 \mathrm{~m}(47.8 \mathrm{ft})$ to the northwest of the collar location, and that the hole is relatively straight (no "dog legs").

A graphical depiction of drilling parameters, including penetration rate, revolutions per minute, pump pressure, and weight on the bit is presented in Appendix A-1. See Appendix A-2 for a listing of casing materials. Drilling fluids and cements used in Well ER-5-3 are listed in Appendix A-3.

\subsubsection{Drilling Problems}

The primary drilling problem on Well ER-5-3 was borehole instability below the depth of about $774.2 \mathrm{~m}$ (2,540 ft), which prompted the early termination of drilling. Above that depth typical stability problems were controlled by adjusting the amounts of polymer and foaming agent in the drilling fluid and the fluid injection rate as necessary to maintain good circulation and penetration rate, and to minimize borehole sloughing. During drilling of the first $168.6 \mathrm{~m}$ (553 ft) of the hole, 1.5 to $3.7 \mathrm{~m}$ ( 5 to $12 \mathrm{ft}$ ) of fill (due to sloughing of the borehole wall) was encountered each time drilling was stopped to add a section of drill rod ("make a connection"), but between this depth and $774.2 \mathrm{~m}(2,540 \mathrm{ft})$ little or no fill was encountered on connections. A few tight spots were encountered during installation of the surface casing to the depth of $374.8 \mathrm{~m}$ $(1,229.6 \mathrm{ft})$, and only about $4.5 \mathrm{~m}(15 \mathrm{ft})$ of fill accumulated during the 4-day safety stand-down when the hole had reached the depth of $726.9 \mathrm{~m}(2,385 \mathrm{ft})$. Fill accumulation in the borehole caused significant delays in the drilling below the depth of about $774.2 \mathrm{~m}(2,540 \mathrm{ft})$. At the time

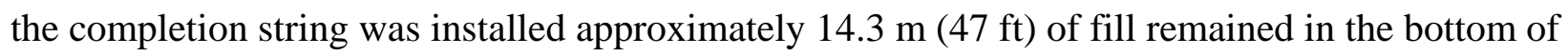
the hole.

High water production below the depth of about $762.0 \mathrm{~m}$ (2,500 ft) caused a delay while another compressor was added.

\subsubsection{Fluid Management}

Drilling effluent was monitored according to the methods prescribed in the UGTA FMP (DOE, 1999). The air-foam/polymer drill fluid was circulated down the inside of the drill string and back up the hole through the annulus (conventional or direct circulation) and then discharged into a sump. Water used to prepare drilling fluids came from Water Wells $5 \mathrm{~b}$ and C-1. Lithium 
bromide ( $\mathrm{LiBr}$ ) was added to the drill fluid as a tracer to provide a means of estimating groundwater production, based on dilution of the $\mathrm{LiBr}$ in the fluid returns.

To manage the anticipated water production, 2 sumps were constructed prior to drilling (Figure 2-1), and Sump \#1 had an overflow pipe. No contaminants were expected during drilling at this site, so neither sump was lined prior to drilling. Samples of drilling effluent were tested onsite hourly for the presence of tritium, and every 8 hours for lead. The onsite monitoring results indicate that tritium remained at background levels, and lead was undetectable (less than 50 parts per billion) during the entire drilling operation (IT, 2000b).

Before fluids are discharged from a sump, the FMP requires that a sample be collected from the sump and analyzed offsite to verify onsite monitoring data and demonstrate compliance with the FMP. A sample was collected from Sump \#1 on February 23, 2000, after drilling of the surface hole. Rinsate from the sampling bucket was also collected as an additional sample. While the sample was being analyzed, geophysical logging of the surface hole was conducted and the surface casing was installed. The analytical results showed the sump fluids were within the parameters of the FMP criteria (IT, 2000b). The sump fluid was not sampled (typically done to determine final disposition of the fluid) after Well ER-5-3 was completed, because the sump would be used again immediately for drilling of Well ER-5-3\#2. Water-quality data for both samples are given in Appendix B.

The results of analyses of samples of drilling fluid collected at Well ER-5-3 during drilling operations indicate that all fluid quality objectives were met, as shown on the fluid management reporting form dated September 21, 2001 (Appendix B). The form lists volumes of solids (drill cuttings) and fluids produced during well-construction operations, Phase I, vadose- and saturated-zone drilling. (The form also includes data for Phase II, well development and aquifer testing, conducted later and not addressed in this report.) The volume of solids produced in Phase I drilling was calculated using the diameter of the borehole (from caliper logs) and the depth drilled, and includes added volume attributed to a rock bulking factor. The volumes of fluids listed on the report are estimates of total fluid production and do not account for evaporation of fluids from the sumps.

\subsection{Geologic Data Collection}

This section describes the sources of geologic data obtained from Well ER-5-3 and the methods

of data collection. Improving the understanding of the subsurface stratigraphy, obtaining data to better quantify physical and mineralogical changes in the alluvium with depth, and obtaining 
velocity data to aid interpretation of surface seismic data were among the objectives for drilling Well ER-5-3, so the proper collection of geologic and hydrogeologic data from the well was considered fundamental to successful completion of the project. Geologic data collected at Well ER-5-3 consist of drill cuttings, sidewall samples, and geophysical logs. Data collection, sampling, transfer, and documentation activities were performed according to applicable contractor procedures.

\subsubsection{Collection of Drill Cuttings}

Composite drill cuttings were collected from Well ER-5-3 at 3-m (10-ft) intervals as drilling progressed from the depth of $32.0 \mathrm{~m}(105 \mathrm{ft})$ to the TD of the well at $794.3 \mathrm{~m}(2,606 \mathrm{ft})$.

Triplicate samples, each consisting of approximately 550 cubic centimeters (cc) (1 pint) of material, were collected from 251 intervals. These samples are stored under secure, environmentally controlled conditions at the U.S. Geological Survey (USGS) Geologic Data Center and Core Library in Mercury, Nevada. One of these sample sets was sealed with custody tape at the rig site and remains sealed as an archive sample; one set was left unsealed in the original sample containers; and the third set was washed and stored according to standard USGS Core Library procedures. The washed set was used by BN to construct the detailed lithologic log presented in Appendix C-1. The IT field representative collected 2 additional sets of reference samples from each of the cuttings intervals. One reference set was examined at the drill site for use in preparing field lithologic descriptions, and remains in the custody of StollerNavarro Joint Venture (SN-JV; IT's successor and the current environmental contractor for NNSA/NSO). The other set remains at LANL where it was sent for petrographic, mineralogic, and chemical analyses.

\subsubsection{Sidewall Core Samples}

Sidewall core samples were collected at selected depths by Schlumberger from Well ER-5-3 to verify the stratigraphy and lithology. Sample locations were selected by the IT field representative on the basis of field lithologic logs, with consideration of borehole conditions determined from caliper logs. A percussion-gun tool was used to collect 41 sidewall cores in the alluvium of the upper $788.0 \mathrm{~m}$ (1,240 ft) of the borehole on February 25, 2000, prior to installation of the surface casing. Prior to installation of the completion string, Schlumberger collected 17 percussion gun and 18 rotary sidewall cores from the lower part of the borehole. Table 2-2 1ists the recovery and stratigraphic assignment for each sample. 
Table 2-2

Sidewall Samples from Well ER-5-3

(Page 1 of 2)

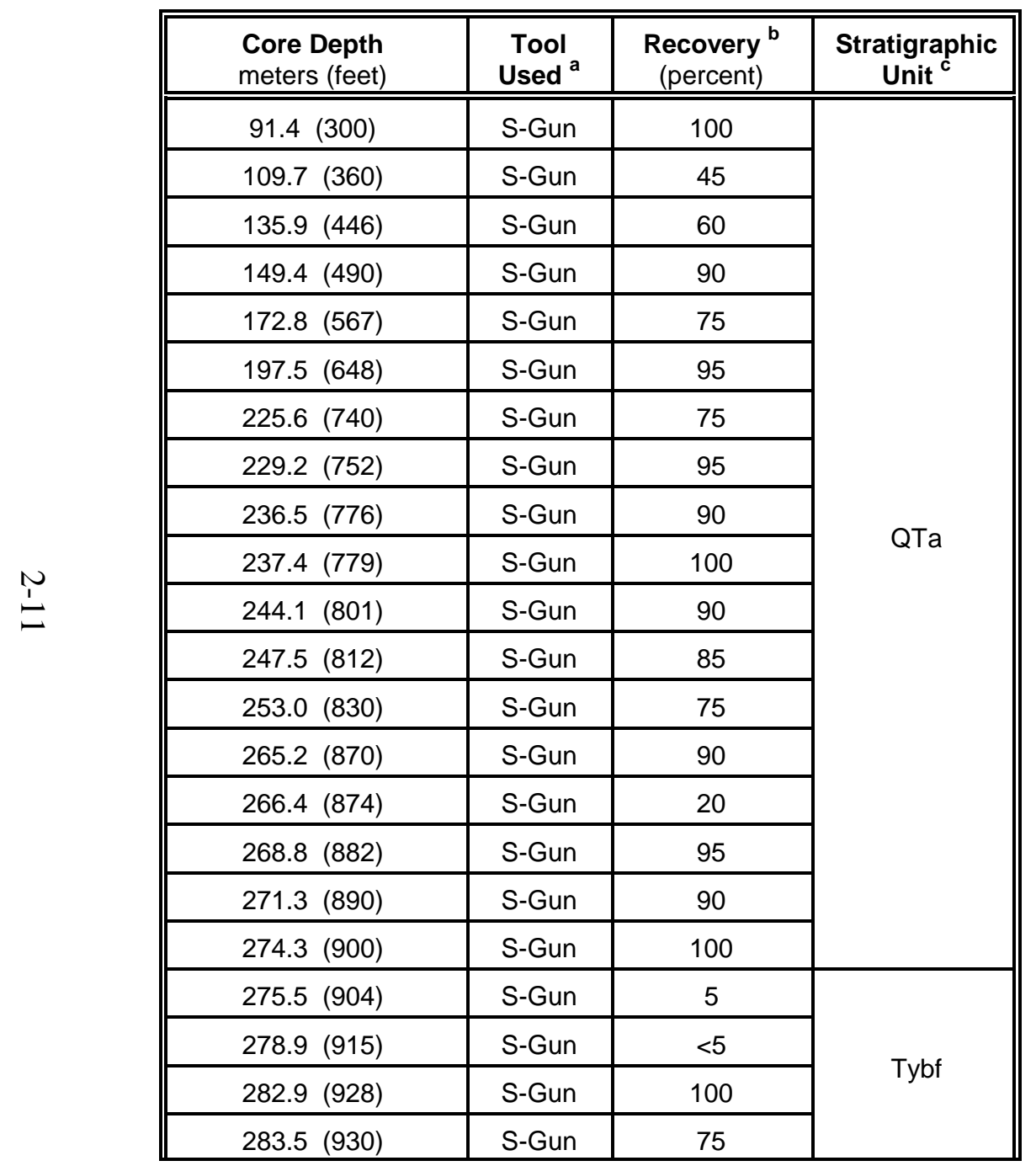

\begin{tabular}{|c|c|c|c|}
\hline $\begin{array}{l}\text { Core Depth } \\
\text { meters (feet) }\end{array}$ & $\begin{array}{c}\text { Tool } \\
\text { Used }^{a}\end{array}$ & $\begin{array}{c}\text { Recovery } \\
\text { (percent) }\end{array}$ & $\begin{array}{c}\text { Stratigraphic } \\
\text { Unit }\end{array}$ \\
\hline 284.1 (932) & S-Gun & 100 & \multirow{23}{*}{$\operatorname{Tg}$} \\
\hline 284.7 (934) & S-Gun & 100 & \\
\hline 285.3 (936) & S-Gun & 90 & \\
\hline $286.5(940)$ & S-Gun & 40 & \\
\hline 287.1 (942) & S-Gun & 80 & \\
\hline 287.7 (944) & S-Gun & 80 & \\
\hline $288.3(946)$ & S-Gun & 35 & \\
\hline 300.2 (985) & S-Gun & 40 & \\
\hline $315.8(1,036)$ & S-Gun & 75 & \\
\hline $317.3(1,041)$ & S-Gun & 5 & \\
\hline $325.8(1,069)$ & S-Gun & 50 & \\
\hline $333.8(1,095)$ & S-Gun & 40 & \\
\hline $335.3(1,100)$ & S-Gun & 75 & \\
\hline $342.0(1,122)$ & S-Gun & 100 & \\
\hline $350.5(1,150)$ & S-Gun & 100 & \\
\hline $351.7(1,154)$ & S-Gun & 100 & \\
\hline $361.8(1,187)$ & S-Gun & 40 & \\
\hline $371.9(1,220)$ & S-Gun & 20 & \\
\hline $378.0(1,240)$ & S-Gun & 60 & \\
\hline $383.9(1,259.9)$ & S-Gun & 30 & \\
\hline $384.0(1,260)$ & MCT & 50 & \\
\hline $394.4(1,294)$ & S-Gun & 40 & \\
\hline $414.5(1,360)$ & MCT & 50 & \\
\hline
\end{tabular}


Table 2-2

Sidewall Samples from Well ER-5-3

(Page 2 of 2)

\begin{tabular}{|c|c|c|c|c|}
\hline & $\begin{array}{l}\text { Core Depth } \\
\text { meters (feet) }\end{array}$ & $\begin{array}{c}\text { Tool } \\
\text { Used }^{a}\end{array}$ & $\begin{array}{c}\text { Recovery } \\
\text { (percent) }\end{array}$ & $\begin{array}{c}\text { Stratigraphic } \\
\text { Unit }\end{array}$ \\
\hline \multirow{16}{*}{$\begin{array}{l}N \\
N \\
N\end{array}$} & $420.6(1,380)$ & S-Gun & 5 & \multirow{7}{*}{$\mathrm{Tg}$} \\
\hline & $422.1(1,385)$ & MCT & 70 & \\
\hline & $445.0(1,460)$ & MCT & 70 & \\
\hline & $448.1(1,470)$ & S-Gun & 100 & \\
\hline & $457.2(1,500)$ & МСТ & 70 & \\
\hline & $489.5(1,606)$ & S-Gun & 100 & \\
\hline & $505.1(1,657)$ & S-Gun & 100 & \\
\hline & $510.2(1,674)$ & S-Gun & 95 & $\begin{array}{l}\text { unidentified } \\
\text { ash within } \mathrm{Tg}\end{array}$ \\
\hline & $521.2(1,710)$ & S-Gun & 90 & \multirow{8}{*}{$\operatorname{Tg}$} \\
\hline & $534.6(1,754)$ & S-Gun & 45 & \\
\hline & $539.5(1,770)$ & S-Gun & 100 & \\
\hline & $545.6(1,790)$ & S-Gun & 100 & \\
\hline & $549.9(1,804)$ & S-Gun & 75 & \\
\hline & $554.7(1,820)$ & S-Gun & 100 & \\
\hline & $584.0(1,916)$ & MCT & 40 & \\
\hline & $608.1(1,995)$ & S-Gun & 50 & \\
\hline
\end{tabular}

\begin{tabular}{|c|c|c|c|}
\hline $\begin{array}{l}\text { Core Depth } \\
\text { meters (feet) }\end{array}$ & $\begin{array}{c}\text { Tool } \\
\text { Used }^{a}\end{array}$ & $\begin{array}{c}\text { Recovery } \\
\text { (percent) }\end{array}$ & $\begin{array}{c}\text { Stratigraphic } \\
\text { Unit }\end{array}$ \\
\hline $627.9(2,060)$ & MCT & 10 & \multirow{5}{*}{ Tmar } \\
\hline $630.9(2,070)$ & MCT & 10 & \\
\hline $644.3(2,114)$ & MCT & 10 & \\
\hline $659.9(2,165)$ & МCT & 85 & \\
\hline $678.2(2,225)$ & MCT & 70 & \\
\hline $690.4 \quad(2,265)$ & MCT & 10 & \multirow{2}{*}{ Tmap } \\
\hline $699.5(2,295)$ & MCT & 85 & \\
\hline $707.1 \quad(2,320)$ & S-Gun & 60 & \multirow{2}{*}{ Tmab } \\
\hline $708.7(2,325)$ & S-Gun & 100 & \\
\hline $711.7(2,335)$ & S-Gun & 45 & \multirow{5}{*}{ Tmrr } \\
\hline $711.7(2,335)$ & MCT & 70 & \\
\hline $717.8(2,355)$ & MCT & 40 & \\
\hline $726.9(2,385)$ & MCT & 85 & \\
\hline $752.9(2,470)$ & MCT & 40 & \\
\hline $770.5(2.528)$ & $\mathrm{MCT}$ & 20 & Tmrp \\
\hline
\end{tabular}

a S-Gun = Percussion sidewall gun; $\mathrm{MCT}=$ rotary mechanical sidewall coring tool; both tools were operated by Schlumberger.

b Estimated.

c Preliminary assignments: QTa = Quaternary or Tertiary alluvium; Tybf = basalt of Frenchman Flat; Tg = Pliocene through Miocene alluvium; Tmar = maficrich Ammonia Tanks Tuff; Tmap = mafic-poor Ammonia Tanks Tuff; Tmab = bedded Ammonia Tanks Tuff; Tmrr = mafic-rich Rainier Mesa Tuff. See Appendix C-1 for a detailed stratigraphic and lithologic log for Well ER-5-3. 


\subsubsection{Sample Analysis}

Thirty samples of drill cuttings from various depths in Well ER-5-3 were submitted to the LANL Earth and Environmental Sciences Division - Geology and Geochemistry laboratories for petrographic, mineralogic, and chemical analyses to aid in stratigraphic identification and for characterization of mineral alteration. As shown in Table 2-3, all planned analyses were completed for these samples. The results of these analyses were reported by Warren (2000) and have been incorporated into the BN geologic interpretation presented in Section 5.0

\subsubsection{Geophysical Logging Data}

Geophysical logs were run to further characterize the lithology, structure, and water content of the rocks encountered. In addition, logs were run to evaluate borehole conditions, to determine the fluid levels during the course of drilling, and to monitor completion progress. Geophysical logging was conducted during 3 stages of drilling and completion: prior to setting surface casing, prior to installing the completion well casing, and during well installation (annulus investigation log). Some logs were run in both the saturated and unsaturated zones of the borehole, while others (e.g., thermal flow log, chemistry log, ultrasonic borehole imager log, etc.) were run only in the saturated interval.

The overall quality of the geophysical data collected was good. However, the Repeat Formation Tester log run in the saturated portion of the borehole by Schlumberger provided very little useful information. This tool, used in other industries as a source of depth-discrete measurements of specific hydraulic parameters, was run in Well ER-5-3 as a test to see if this tool could provide useful data in this type of environment. Considerable difficulty was encountered in getting the tool to seat properly, and eventually the tool became stuck in the borehole, causing a significant loss of time while a subcontractor was brought on site to recover the tool.

A complete listing of the logs, dates run, depths and service companies is provided in Table 2-4. The logs are available from BN in Mercury, Nevada, and copies are on file at the SN-JV office in Las Vegas, NV. Preliminary geophysical data from selected logs are reproduced in Appendix D. 
Table 2-3

Status of Rock Sample Analyses for Well ER-5-3

(Page 1 of 2)

\begin{tabular}{|c|c|c|c|c|c|c|}
\hline \multirow{3}{*}{$\begin{array}{c}\text { Depth }^{\text {a }} \\
\text { meters (feet) }\end{array}$} & \multirow{3}{*}{$\begin{array}{l}\text { Sample } \\
\text { Type }\end{array}$} & \multicolumn{5}{|c|}{ Analyses Performed $^{c}$} \\
\hline & & \multirow{2}{*}{$\frac{\text { Petrographic }}{\text { PTS }}$} & \multicolumn{2}{|c|}{ Mineralogic } & \multicolumn{2}{|c|}{ Chemical } \\
\hline & & & MP & XRD & XRF & $\begin{array}{l}\mathrm{Fe}^{2+} \mathrm{I} \\
\mathrm{Fe}^{3+}\end{array}$ \\
\hline $91.4(300)$ & SC & $\mathrm{C}$ & -- & $\mathrm{C}$ & - & - \\
\hline $109.7(360)$ & SC & - & -- & $\mathrm{C}$ & - & - \\
\hline $135.9(446)$ & SC & - & -- & C & - & - \\
\hline $172.8(567)$ & SC & $\mathrm{C}$ & -- & $\mathrm{C}$ & - & - \\
\hline $197.5(648)$ & SC & $\mathrm{C}$ & -- & $\mathrm{C}$ & - & - \\
\hline 204.2 (670) & DB1 & $\mathrm{C}$ & -- & $\mathrm{C}$ & $\mathrm{C}$ & $\mathrm{C}$ \\
\hline $225.6(740)$ & SC & - & -- & $\mathrm{C}$ & - & - \\
\hline $229.2(752)$ & SC & $\mathrm{C}$ & -- & $\mathrm{C}$ & - & - \\
\hline $236.5(776)$ & $\mathrm{SC}$ & $\mathrm{C}$ & -- & C & - & - \\
\hline 237.4 (779) & $\mathrm{SC}$ & - & -- & $\mathrm{C}$ & - & - \\
\hline 244.1 (801) & SC & - & -- & $\mathrm{C}$ & - & -- \\
\hline $247.5(812)$ & SC & $\mathrm{C}$ & -- & C & - & -- \\
\hline $253.0(830)$ & SC & -- & -- & C & -- & -- \\
\hline $259.1(850)$ & DB1 & $\mathrm{C}$ & -- & C & $\mathrm{C}$ & C \\
\hline $265.2(870)$ & SC & $\mathrm{C}$ & -- & $\mathrm{C}$ & -- & -- \\
\hline 268.8 (882) & SC & - & -- & C & - & - \\
\hline $271.3(890)$ & SC & - & - & $\mathrm{C}$ & - & - \\
\hline $274.3(900)$ & SC & - & - & C & - & - \\
\hline $284.1(932)$ & SC & $\mathrm{C}$ & -- & $\mathrm{C}$ & - & - \\
\hline $284.7(934)$ & SC & -- & -- & C & -- & -- \\
\hline $285.3(936)$ & SC & -- & -- & C & -- & -- \\
\hline $286.5(940)$ & DB1 & C & - - & C & C & C \\
\hline $287.1(942)$ & SC & -- & - - & C & -- & -- \\
\hline 287.7 (944) & SC & -- & -- & C & -- & -- \\
\hline $288.3(946)$ & SC & - & -- & C & -- & -- \\
\hline 300.2 (985) & SC & $\mathrm{C}$ & -- & C & -- & -- \\
\hline $315.8(1,036)$ & $\mathrm{SC}$ & $\mathrm{C}$ & -- & C & -- & - \\
\hline $320.0(1,050)$ & DB1 & $\mathrm{C}$ & -- & C & $\mathrm{C}$ & C \\
\hline
\end{tabular}


Table 2-3

Status of Rock Sample Analyses for Well ER-5-3

(Page 2 of 2)

\begin{tabular}{|c|c|c|c|c|c|c|}
\hline \multirow{3}{*}{$\begin{array}{c}\text { Depth }^{\mathbf{a}} \\
\text { meters (feet) }\end{array}$} & \multirow{3}{*}{$\begin{array}{l}\text { Sample } \\
\text { Type }\end{array}$} & \multicolumn{5}{|c|}{ Analyses Performed $^{c}$} \\
\hline & & \multirow{2}{*}{$\begin{array}{c}\text { Petrographic } \\
\text { PTS }\end{array}$} & \multicolumn{2}{|c|}{ Mineralogic } & \multicolumn{2}{|c|}{ Chemical } \\
\hline & & & MP & XRD & XRF & $\begin{array}{l}\mathrm{Fe}^{2+} \mathrm{I} \\
\mathrm{Fe}^{3+} \\
\end{array}$ \\
\hline $325.8(1,069)$ & SC & $\mathrm{C}$ & -- & $\mathrm{C}$ & - & - \\
\hline $335.5(1,100)$ & SC & - & -- & C & - & - \\
\hline $342.0(1,122)$ & SC & C & -- & C & - & - \\
\hline $350.5(1,150)$ & SC & - & -- & C & - & - \\
\hline $351.7(1,154)$ & $\mathrm{SC}$ & $\mathrm{C}$ & -- & $\mathrm{C}$ & - & - \\
\hline $353.6(1,160)$ & DB1 & $\mathrm{C}$ & -- & $\mathrm{C}$ & $\mathrm{C}$ & $\mathrm{C}$ \\
\hline $361.8(1,187)$ & $\mathrm{SC}$ & $\mathrm{C}$ & -- & $\mathrm{C}$ & - & - \\
\hline $378.0(1,240)$ & SC & $\mathrm{C}$ & -- & $\mathrm{C}$ & - & - \\
\hline $383.9(1,259.5)$ & SC & - & -- & $\mathrm{C}$ & - & -- \\
\hline $384.0(1,260)$ & SC & $\mathrm{C}$ & -- & C & - & -- \\
\hline $414.5(1,360)$ & SC & $\mathrm{C}$ & -- & - & -- & - \\
\hline $454.2(1,490)$ & DA & $\mathrm{C}$ & -- & $\mathrm{C}$ & $\mathrm{C}$ & $\mathrm{C}$ \\
\hline $512.1(1,680)$ & DA & $\mathrm{C}$ & -- & C & $\mathrm{C}$ & $\mathrm{C}$ \\
\hline $536.4(1,760)$ & DA & $\mathrm{C}$ & -- & $\mathrm{C}$ & $\mathrm{C}$ & C \\
\hline $566.9(1,860)$ & DA & $\mathrm{C}$ & -- & $\mathrm{C}$ & $\mathrm{C}$ & $\mathrm{C}$ \\
\hline $609.6(2,000)$ & DA & $\mathrm{C}$ & -- & C & $\mathrm{C}$ & $\mathrm{C}$ \\
\hline $627.9(2,060)$ & DA & $\mathrm{C}$ & -- & C & C & C \\
\hline $701.0(2,300)$ & DA & $\mathrm{C}$ & -- & C & $\mathrm{C}$ & $\mathrm{C}$ \\
\hline $716.3(2,350)$ & DA & $\mathrm{C}$ & -- & C & $\mathrm{C}$ & C \\
\hline
\end{tabular}

a Depth represents base of 3.0-m (10-ft) sample interval for drill cuttings.

b $\quad$ DA = drill cuttings that represent lithologic character of interval; DB1 = drill cuttings enriched in hard component; $\mathbf{S C}=$ sidewall core.

C Analysis type: PTS = polished thin section; $\mathbf{M P}=$ electron microprobe; $\mathbf{X R D}=\mathrm{X}$-ray diffraction; $\mathbf{X R F}=\mathrm{X}$-ray fluorescence; $\mathbf{F E}^{+2} / \mathrm{FE}^{+3}=$ wet chemical analysis for iron. Analysis status: $\mathbf{C}$ indicates analysis is complete. - - indicates analysis was not planned. 
Table 2-4

Well ER-ER-5-3 Geophysical Log Summary

(Page 1 of 2)

\begin{tabular}{|c|c|c|c|c|c|c|}
\hline Geophysical Log Type ${ }^{a}$ & Log Purpose & $\begin{array}{l}\text { Logging } \\
\text { Service }\end{array}$ & Date Logged & Run Number & $\begin{array}{c}\text { Bottom of Logged } \\
\text { Interval } \\
\text { meters (feet) } \\
\end{array}$ & $\begin{array}{c}\text { Top of Logged } \\
\text { Interval } \\
\text { meters (feet) } \\
\end{array}$ \\
\hline * Natural Gamma Ray Spectroscopy & $\begin{array}{l}\text { Stratigraphic correlation, } \\
\text { mineralogy, natural and man-made } \\
\text { radiation }\end{array}$ & Schlumberger & $\begin{array}{l}02 / 25 / 2000 \\
03 / 08 / 2000\end{array}$ & $\begin{array}{l}\text { SGR-1 } \\
\text { SGR-2 }\end{array}$ & $\begin{array}{l}373.7(1,226) \\
769.3(2,524)\end{array}$ & $\begin{array}{c}0 \\
362.7(1,190)\end{array}$ \\
\hline *Gamma Ray / Four Arm Caliper & $\begin{array}{l}\text { Borehole conditions, cement volume } \\
\text { calculation / } \\
\text { stratigraphic correlation }\end{array}$ & Schlumberger & $\begin{array}{l}02 / 25 / 2000 \\
03 / 08 / 2000\end{array}$ & $\begin{array}{l}\text { GR-1 / CA4-1 } \\
\text { GR-3 / CA4-2 }\end{array}$ & $\begin{array}{l}380.4(1,248) \\
780.9(2,562)\end{array}$ & $\begin{array}{c}0 \\
347.5(1,140)\end{array}$ \\
\hline $\begin{array}{l}\text { * Array Induction Log / Caliper / } \\
\text { Gamma Ray / * Spontaneous } \\
\text { Potential }\end{array}$ & $\begin{array}{l}\text { Lithologic determination / } \\
\text { borehole conditions / } \\
\text { stratigraphic correlation }\end{array}$ & Schlumberger & $02 / 25 / 2000$ & $\begin{array}{l}\text { GR-2 / CAL-1/ } \\
\text { AIT-1 / SP-1 }\end{array}$ & $377.6(1,239)$ & 0 \\
\hline $\begin{array}{l}\text { * Epithermal Neutron / Density / } \\
\text { Gamma Ray / Caliper }\end{array}$ & $\begin{array}{l}\text { Total water content / rock porosity / } \\
\text { stratigraphic correlation/borehole } \\
\text { conditions }\end{array}$ & Schlumberger & $\begin{array}{l}02 / 25 / 2000 \\
03 / 08 / 2000\end{array}$ & $\begin{array}{l}\text { GR-2 / ENP-1/ } \\
\text { CDL-1 / CAL-1 } \\
\text { GR-4 / ENP-2 / } \\
\text { CDL-2 / CAL-2 }\end{array}$ & $\begin{array}{l}374.6(1,229) \\
780.3(2,560)\end{array}$ & $\begin{array}{c}0 \\
257.9(846)\end{array}$ \\
\hline $\begin{array}{l}\text { * Dual Laterolog / * Spontaneous } \\
\text { Potential / Gamma Ray }\end{array}$ & $\begin{array}{l}\text { Saturated zone: water saturation / } \\
\text { stratigraphic correlation }\end{array}$ & Schlumberger & 03/09/2000 & DLL-1 / GR-6 & $776.3(2,547)$ & $374.9(1,230)$ \\
\hline $\begin{array}{l}\text { Gamma Ray / Digital Array Sonic } \\
\text { A. Wave-form and variable density } \\
\text { presentations } \\
\text { B. Sonic porosity and travel time } \\
\text { (STC) computations }\end{array}$ & $\begin{array}{l}\text { Saturated zone: } \\
\text { A. Porosity, lithologic determination } \\
\text { B. Fracture identification }\end{array}$ & Schlumberger & 03/08/2000 & AC-1 / GR-5 & $778.8(2,555)$ & $\begin{array}{l}\text { A: } 313.9(1,030) \\
\text { B: } 317.0(1,040)\end{array}$ \\
\hline Ultrasonic Borehole Imager & $\begin{array}{l}\text { Saturated zone: lithologic } \\
\text { characterization, fracture and void } \\
\text { analysis. }\end{array}$ & Schlumberger & 03/08/2000 & BHTV-1 & $777.9(2,552)$ & $363.9(1,194)$ \\
\hline Temperature / Gamma Ray & $\begin{array}{l}\text { Saturated zone: groundwater } \\
\text { temperature / stratigraphic } \\
\text { correlation }\end{array}$ & Schlumberger & 03/08/2000 & TL-1 / GR-3 & $770.2(2,527)$ & $199.3(654)$ \\
\hline $\begin{array}{l}\text { Percussion Sidewall Coring Tool / } \\
\text { Spontaneous Potential }\end{array}$ & $\begin{array}{l}\text { Geologic samples / } \\
\text { stratigraphic correlation }\end{array}$ & Schlumberger & $\begin{array}{l}02 / 25 / 2000 \\
03 / 09 / 2000\end{array}$ & $\begin{array}{l}\text { SGUN-1 / SP-2 } \\
\text { SGUN-2 / SP-4 }\end{array}$ & $\begin{array}{l}788.0(1,240) \\
771.8(2,532)\end{array}$ & $\begin{array}{c}91.4(300) \\
645.6(2,118)\end{array}$ \\
\hline $\begin{array}{l}\text { Mechanical Sidewall Coring Tool / } \\
\text { Gamma Ray }\end{array}$ & $\begin{array}{l}\text { Geologic samples / } \\
\text { stratigraphic correlation }\end{array}$ & Schlumberger & 03/09/2000 & MCT-1 / GR-7 & $770.5(2,562)$ & $384.1(1,260)$ \\
\hline
\end{tabular}


Table 2-4

Well ER-5-3 Geophysical Log Summary

(Page 2 of 2)

\begin{tabular}{|c|c|c|c|c|c|c|}
\hline Geophysical Log Type $^{\text {a }}$ & Log Purpose & $\begin{array}{l}\text { Logging } \\
\text { Service }\end{array}$ & Date Logged & Run Number & $\begin{array}{c}\text { Bottom of Logged } \\
\text { Interval } \\
\text { meters (feet) }\end{array}$ & $\begin{array}{c}\text { Top of Logged } \\
\text { Interval } \\
\text { meters (feet) } \\
\end{array}$ \\
\hline Repeat Formation Tester & Formation pore pressure & Schlumberger & 03/09/2000 & RFT-1 & $770.8(2,529)$ & $393.2(1,290)$ \\
\hline * Thermal Flow Log & $\begin{array}{l}\text { Rate and direction of groundwater } \\
\text { flow in borehole }\end{array}$ & $\begin{array}{l}\text { Desert } \\
\text { Research } \\
\text { Institute }\end{array}$ & $03 / 12 / 2000$ & 1 & $768.1(2,520)$ & $411.5(1,350)$ \\
\hline * Chemistry/Temperature Log & $\begin{array}{l}\text { Groundwater chemistry and } \\
\text { temperature, formation } \\
\text { transmissivity }\end{array}$ & $\begin{array}{l}\text { Desert } \\
\text { Research } \\
\text { Institute }\end{array}$ & 03/12/2000 & 1 & $780.9(2,662)$ & $282.5(927)$ \\
\hline Nuclear Annulus Investigation Log & Well construction monitoring & Colog & $\begin{array}{c}02 / 27 / 2000 \\
03 / 14-16 / 2000\end{array}$ & $\begin{array}{l}\text { AIN-1 } \\
\text { AIN-2 }\end{array}$ & $\begin{array}{r}297.5(976) \\
777.5(2,551)\end{array}$ & $\begin{array}{c}0 \\
6.1(20)\end{array}$ \\
\hline Gyroscopic Directional Survey & Borehole deviation & Gyrodata & $02 / 15 / 2001$ & 1 & $773.3(2,537)$ & 0 \\
\hline
\end{tabular}

a Logs presented in geophysical log summary, Appendix D, are indicated by *.

b Depth below ground surface. 


\subsection{Hydrology of Well ER-5-3}

\subsubsection{Preliminary Water Level Information}

Based on the pre-construction estimate of surface elevation at the site, depth to water was expected to be approximately $287.4 \mathrm{~m}$ (943 ft) (IT, 2000a). Fluid depths between 281.5 and $283.5 \mathrm{~m}$ (923.6 and $930 \mathrm{ft}$ ) were obtained from various geophysical logs run between February 25 and March 16, 2000, before the completion string was installed. The last measurement made during the logging episode just prior to installation of the completion string was at the depth of $282.6 \mathrm{~m}(927 \mathrm{ft})$. Based on this preliminary fluid depth and the as-built surface elevation of elevation of 1,016.3 $\mathrm{m}$ (3,334.3 ft), the fluid level elevation at Well Cluster ER-5-3 is $733.8 \mathrm{~m}(2,407.3 \mathrm{ft})$. This is approximately $0.9 \mathrm{~m}(3 \mathrm{ft})$ above the predicted elevation of $734.6 \mathrm{~m}(2,410 \mathrm{ft})$. A transducer for monitoring of the water level was not installed at the time of completion, but hydrologic testing planned for after completion of Well Cluster ER-5-3 will provide more accurate water level data.

\subsubsection{Preliminary Water Production Information}

Water production was estimated during drilling of the wells in the ER-5-3 cluster on the basis of $\mathrm{LiBr}$ dilution data as measured by IT field personnel (IT, 2000b). Water was first detected in Well ER-5-3 when drilling had reached the depth of 292.6 m (960 ft) on February 24, 2000. Water production remained fairly low, at less than $19 \mathrm{lpm}$ (5 gpm), but gradually increased to about $568 \mathrm{lpm}$ (150 gpm) at the depth of $640.1 \mathrm{~m}$ (2,100 ft) as drilling penetrated the ash-flow tuffs of the Ammonia Tanks Tuff. The water production rate continued to increase as drilling continued through the volcanic rocks, and then remained at about 1,892 lpm (500 gpm) through the nonwelded and bedded portions of the Ammonia Tanks and Rainier Mesa tuffs. Deeper in the welded Rainier Mesa Tuff, water production reached 8,325 lpm (2,200 gpm) at the depth of $784.6 \mathrm{~m}(2,574 \mathrm{ft})$ and continued at that rate to the TD of the hole.

\subsubsection{Preliminary Thermal Flow Log Data}

Flow meter data, along with temperature, electrical conductivity (EC), and pH measurements, can be used to characterize borehole fluid variability, which may indicate inflow and outflow zones. The designs of the completion strings at Well Cluster ER-5-3 were based in part on data from these measurements.

Desert Research Institute (DRI) personnel made measurements with their thermal flow meter (TFM) tool at 4 locations between the depths of (1,350 and 2,520 ft). Based on a preliminary evaluation of the TFM data, the 2 measurements made in the alluvium section indicate upward 
groundwater flow at rates of 0.412 to $0.447 \mathrm{lpm}(0.109$ to $0.118 \mathrm{gpm})$. The 2 measurements made in the volcanic rocks indicate downward flow at rates of 0.923 and $0.530 \mathrm{lpm}$ (0.244 and $0.140 \mathrm{gpm})$.

In addition, DRI ran a chemistry log that included measurements of temperature, EC, and $\mathrm{pH}$, from the top of the fluid column at $282.5 \mathrm{~m}$ (927 ft) to the depth of $780.9 \mathrm{~m}$ (2,662 ft). Groundwater temperature gradually increased from the minimum reading of 23.1 degrees Celsius (73.6 degrees Fahrenheit) at the top of fluid to 29.2 degrees Celsius (84.6 degrees Fahrenheit) at $780.9 \mathrm{~m}$ (2,662 ft). Plots of the unprocessed TFM and chemistry log data are reproduced in Appendix D-1.

\subsubsection{Preliminary Groundwater Characterization Samples}

Following geophysical logging, DRI collected one preliminary groundwater characterization sample to provide initial groundwater chemistry data from the well, based on a suite of analytical parameters. The 5-liter (1.3-gallon) sample was collected from the open borehole at the depth of $725.4 \mathrm{~m}$ (2,380 ft). Analytical data from this initial sample, collected before formal well development, will provide a basis for comparison with future groundwater chemistry data.

\subsection{Precompletion and Open-Hole Development}

No precompletion open-hole development was conducted in Well ER-5-3 before installation of the completion string.

\subsection{Completion}

Well completion refers to the installation in a borehole of a string of pipe or casing that is slotted or screened at one or more locations along its length. The completion process also typically includes emplacement of backfill materials around the casing, with coarse fill such as gravel adjacent to the open intervals and impervious materials such as cement between the open intervals to isolate them. The casing serves as a conduit for insertion of a pump in the well, for inserting devices for measuring fluid level, and for sampling, so that accurate potentiometric and water chemistry data can be collected from known portions of the hole.

Piezometer String \#1 was installed in the upper part of Well ER-5-3 on February 26, 2000. Piezometer String \#2 and the production casing were installed on March 13 to16, 2000.

Figure 2-2 is a schematic diagram of the final well completion design for Well ER-5-3;

Figure 2-3 shows a plan view and profile of the wellhead surface completion; and Table 2-5 is a construction summary for the well. 


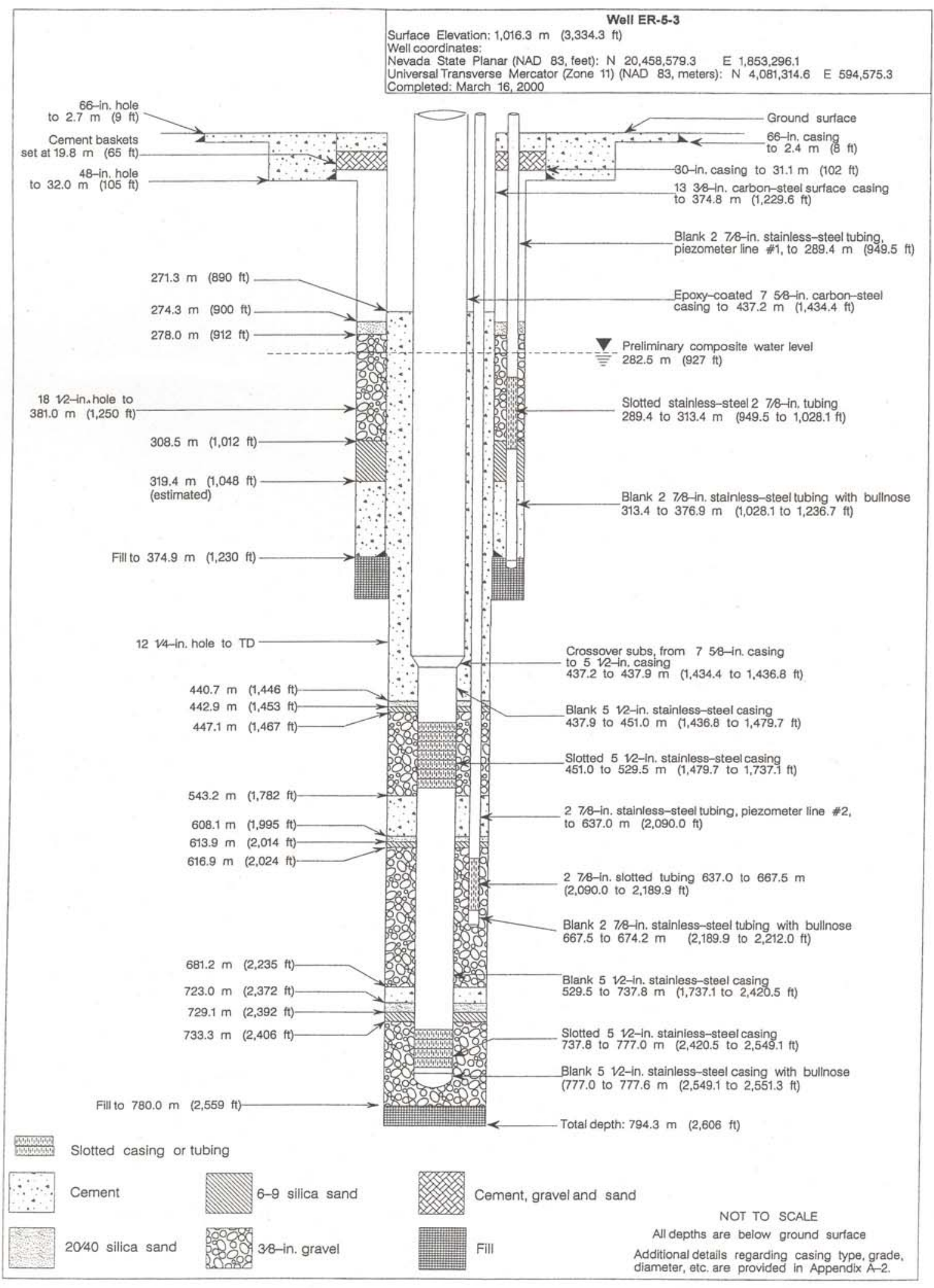

Figure 2-2

As-Built Completion Schematic for Well ER-5-3 


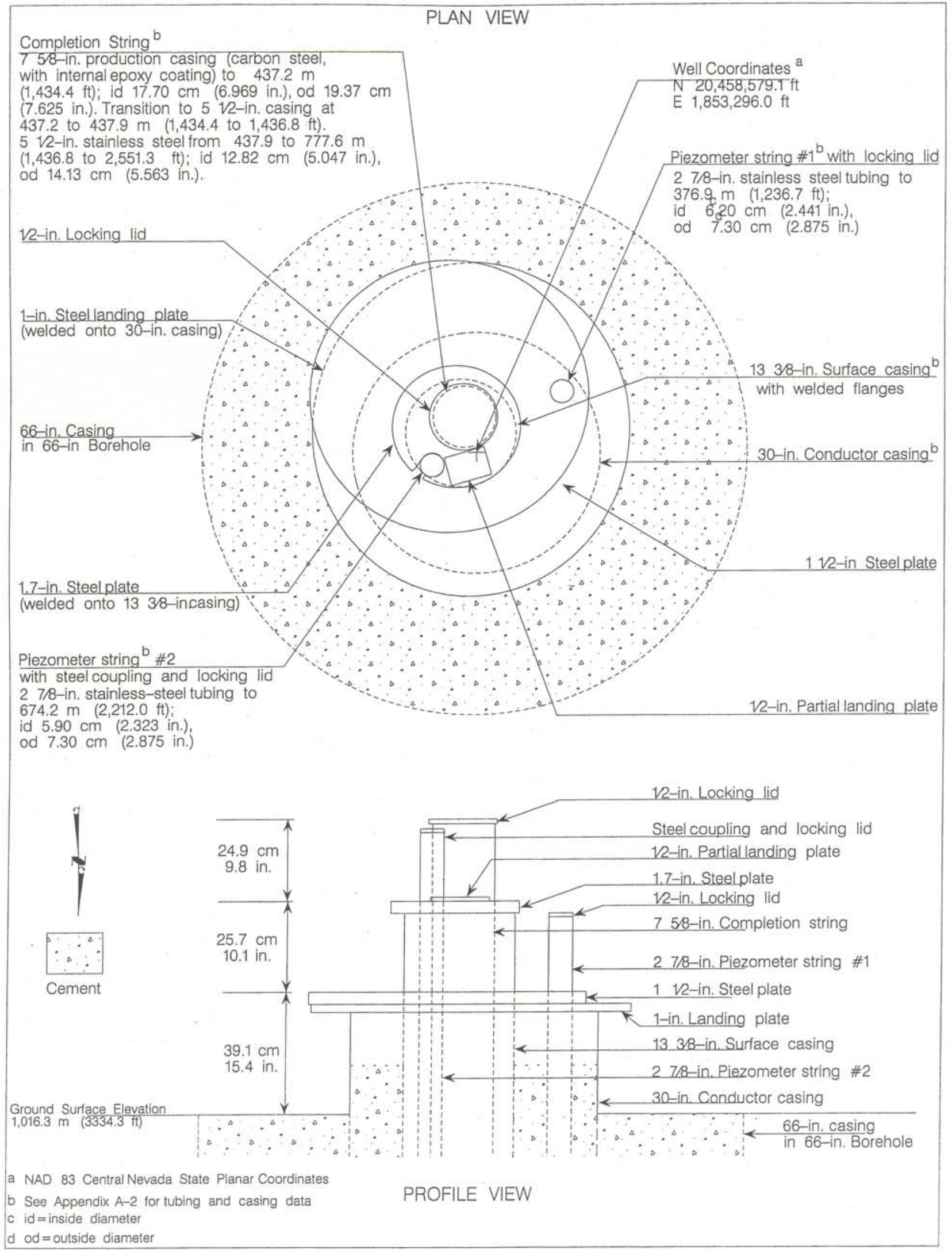

Figure 2-3

Wellhead Diagram for Well ER-5-3 


\section{Table 2-5
Well ER-5-3 Completion String Construction Summary}

\begin{tabular}{|c|c|c|c|c|}
\hline Casing/Tubing Type & \multicolumn{2}{|c|}{$\begin{array}{c}\text { Configuration } \\
\text { meters (feet) }\end{array}$} & $\begin{array}{c}\text { Cement } \\
\text { meters (feet) }\end{array}$ & $\begin{array}{l}\text { Sand/Gravel } \\
\text { meters (feet) }\end{array}$ \\
\hline $\begin{array}{l}75 / 8 \text {-in. carbon-steel } \\
\text { production casing with } \\
\text { internal epoxy coating }\end{array}$ & $\begin{array}{c}0 \text { to } 437.2 \\
(0 \text { to } 1,434.4)\end{array}$ & Blank & Type II & \\
\hline $\begin{array}{c}75 / 8 \text {-in. to } 51 / 2 \text {-in. cross- } \\
\text { over sub, carbon steel } \\
\text { with a stainless-steel } \\
\text { double pin }\end{array}$ & $\begin{array}{c}437.2 \text { to } 437.9 \\
(1,434.4 \text { to } 1,436.8)\end{array}$ & Blank & $\begin{array}{l}271.3 \text { to } 440.7 \\
\text { (890 to } 1,446)\end{array}$ & None \\
\hline \multirow{4}{*}{$\begin{array}{l}\text { 51/2-in. stainless-steel } \\
\text { production casing }\end{array}$} & \multirow{4}{*}{$\begin{array}{c}437.9 \text { to } 777.6 \\
(1,436.8 \text { to } 2,551.3)\end{array}$} & $\begin{array}{c}\text { Blank } \\
437.9 \text { to } 451.0 \\
(1,436.8 \text { to } 1,379.7)\end{array}$ & \multirow{7}{*}{$\begin{array}{c}543.2 \text { to } 608.1 \\
(1,782 \text { to } 1,995)\end{array}$} & $\begin{array}{c}\underline{20 / 40 \text { Sand }} \\
440.7 \text { to } 442.9 \\
(1,446 \text { to } 1,453)\end{array}$ \\
\hline & & $\begin{array}{c}\text { Slotted } \\
451.0 \text { to } 529.5 \\
(1,479.7 \text { to } 1,737.1)\end{array}$ & & $\begin{array}{c}608.1 \text { to } 613.9 \\
(1,995 \text { to } 2,014)\end{array}$ \\
\hline & & $\begin{array}{c}\text { Blank } \\
529.5 \text { to } 737.8 \\
(1,737.1 \text { to } 2,420.5)\end{array}$ & & $\begin{array}{c}(2,372 \text { to } 2,392) \\
\underline{6-9 \text { Sand }}\end{array}$ \\
\hline & & $\begin{array}{l}\text { Slotted and bull-nosed } \\
737.8 \text { to } 777.6 \\
(2,420.5 \text { to } 2,551.3)\end{array}$ & & $\begin{array}{c}(1,453 \text { to } 1,467) \\
613.9 \text { to } 616.9 \\
(2,014 \text { to } 2,024)\end{array}$ \\
\hline \multirow{3}{*}{$\begin{array}{c}\text { Piezometer \#2 } \\
\begin{array}{c}\text { 27/8-in. stainless-steel } \\
\text { tubing }\end{array}\end{array}$} & \multirow{3}{*}{$\begin{array}{c}0 \text { to } 674.2 \\
(0 \text { to } 2,212.0)\end{array}$} & $\begin{array}{c}\text { Blank } \\
0 \text { to } 637.0 \\
\text { (0 to } 2,090.0)\end{array}$ & & $\begin{array}{c}729.1 \text { to } 733.3 \\
(2,392 \text { to } 2,406)\end{array}$ \\
\hline & & $\begin{array}{c}\text { Slotted } \\
637.0 \text { to } 667.5 \\
(2,090.0 \text { to } 2,189.9\end{array}$ & & $\begin{array}{c}447.1 \text { to } 543.2 \\
(1,467 \text { to } 1,782)\end{array}$ \\
\hline & & $\begin{array}{c}\text { Blank and bull-nosed } \\
667.5 \text { to } 674.2 \\
(2,189.9 \text { to } 2,212.0)\end{array}$ & & $\begin{array}{c}(2,024 \text { to } 2,235) \\
733.3 \text { to } 780.0 \\
(2,406 \text { to } 2,559)\end{array}$ \\
\hline \multirow{3}{*}{ 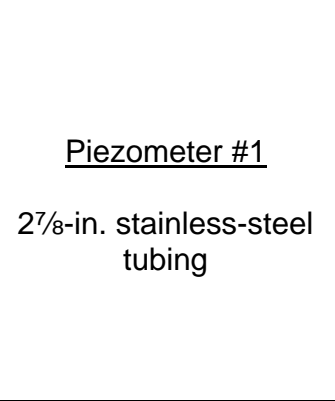 } & \multirow{3}{*}{$\begin{array}{c}0 \text { to } 376.9 \\
(0 \text { to } 1,236.7)\end{array}$} & $\begin{array}{c}\text { Blank } \\
0 \text { to } 289.4 \\
\text { (0 to } 949.5 \text { ) }\end{array}$ & \multirow{3}{*}{$\begin{array}{c}319.4 \text { to } 374.9 \\
(1,048 \text { to } 1,230)\end{array}$} & $\begin{array}{l}2 \frac{20 / 40 \text { Sand }}{274.3 \text { to } 278.0} \\
\text { (900 to } 912)\end{array}$ \\
\hline & & $\begin{array}{c}\text { Slotted } \\
289.4 \text { to } 313.4 \\
(949.5 \text { to } 1,028.1)\end{array}$ & & $\begin{array}{c}\frac{6-9 \text { Sand }}{308.5 \text { to } 319.4} \\
(1,012 \text { to } 1,048)\end{array}$ \\
\hline & & $\begin{array}{c}\text { Blank and bull-nosed } \\
313.4 \text { to } 376.9 \\
(1,028.1 \text { to } 1,236.7)\end{array}$ & & $\begin{array}{l}\frac{3 / 8 \text {-in. Gravel }}{278.0 \text { to } 308.5} \\
\text { (912 to } 1,012 \text { ) }\end{array}$ \\
\hline
\end{tabular}


Data for this section were obtained from daily operations and activity reports, casing records, and cementing records provided by the BN Drilling Department. Information from IT's well data report (IT, 2000b) was also consulted for preparation of this section.

\subsubsection{Proposed Completion Design}

The original completion design (IT, 2000a) was based on the assumption that Well ER-5-3 would reach TD in carbonate rocks of the lower carbonate aquifer. The well was planned to be constructed with 3 completion zones, 1 each in the lower carbonate aquifer, the tuff confining unit, and at the base of the alluvium. A string of 51/2-in. stainless-steel casing (suspended from carbon-steel 75/8-in. casing) with 2 slotted sections would be installed to provide access to the base of the alluvial section and to the carbonate rocks. A string of $27 / 8$-in. tubing would be installed as a piezometer outside the production casing to provide access, via a slotted section, to rocks of the tuff confining unit.

\subsubsection{As-Built Completion Design}

The actual design of the Well ER-5-3 completion was determined through consultation with members of the UGTA TWG, on the basis of onsite evaluation of data such as lithology and water production, drilling data (lost circulation, etc.), data from geophysical logs (particularly caliper, borehole video, acoustic fracture log), and from thermal-flow and water chemistry logs.

The as-built completion design for Well ER-5-3 provides access to 2 zones within the saturated alluvium section and 2 zones in the welded tuff aquifer. The composition of the completion strings summarized here is detailed on Table 2-5, and the tubing and casing materials are listed in Appendix A-3. The lower section of the completion string (51/2-in. casing), from 437.7 to $777.6 \mathrm{~m}$ (1,435.9 to 2,551.3 ft), is type SSTP304 stainless-steel casing with an outside diameter of $14.13 \mathrm{~cm}$ (5.563 in.) and an inside diameter of $12.82 \mathrm{~cm}$ (5.047 in.) The top of the 51/2-in. casing is approximately $141 \mathrm{~m}(463 \mathrm{ft})$ below the static fluid level. The bottom $0.6 \mathrm{~m}(2.2 \mathrm{ft})$ is blank and terminates in a bull-nose to serve as a sediment sump. Above the 51/2-in. casing, a 0.7-m (2.4-ft) long cross-over sub serves as the transition to the upper part of the string, which is 75/8-in. carbon-steel production casing with an internal epoxy coating. Piezometer String \#2 consists of a bull-nosed string of stainless-steel $27 / 8$-in. tubing set in the annulus of the production casing at a depth of $674.2 \mathrm{~m}$ (2,212.0 ft). Piezometer String \#1 is also made up of bull-nosed, $27 / 8$-in. stainless-steel tubing, set in the annulus of the $13 \% / 8$-in. casing at a depth of $376.9 \mathrm{~m}(1,236.7 \mathrm{ft})$.

The lowest slotted casing interval, 737.8 to $777.0 \mathrm{~m}$ (2,420.5 to 2,549.1 ft), is open to welded ash-flow tuff of the Rainier Mesa Tuff (see the geology discussion for this site in Section 5.0; see 
Figure 5-2 for an illustration of slotted intervals relative to hydrogeologic units). This casing interval consists of 3 consecutive slotted joints. The upper slotted interval of the $51 / 2$-in. casing, 451.0 to $529.5 \mathrm{~m}(1,479.7$ to $1,737.1 \mathrm{ft})$, consists of 6 consecutive slotted joints and is open to the gravelly sands of the lower alluvial section. Piezometer String \#2, placed between the borehole wall and the production casing, contains 5 consecutive slotted joints in the depth interval 637.0 to $667.5 \mathrm{~m}$ (2,090.0 to 2,189.9 ft). This completion zone is open to the welded ash-flow tuff of the Ammonia Tanks Tuff. Piezometer String \#1 contains 4 slotted joints in the interval 289.4 to $313.4 \mathrm{~m}$ (949.5 to $1,028.1 \mathrm{ft}$ ), and is open to the alluvial aquifer.

The openings in each slotted casing joint are $0.198 \mathrm{~cm}(0.078 \mathrm{in}$.) wide and $7.6 \mathrm{~cm}$ (3 in.) long, cut in rings of 18 slots spaced 20 degrees apart around the joint. The rings are spaced $15.2 \mathrm{~cm}$ (6 in.) apart, and the longitudinal centers of the slots in each ring are staggered 10 degrees from the slot centers in the next ring. No slots are cut within $0.6 \mathrm{~m}(2 \mathrm{ft})$ of the ends of the slotted joints to assure that the strength of the pipe near connections is not degraded.

The openings in each slotted joint of the $27 / 8$-in. piezometer tubing are $5.715 \mathrm{~cm}$ (2.25 in.) long and $0.030 \mathrm{~cm}$ (0.012 in.) wide, placed on staggered 15.2-cm (6-in.) centers.

\subsubsection{Rationale for Difference Between Actual and Proposed Well Design}

The proposed completion design included completion zones in the 3 main expected hydrostratigraphic units: the saturated alluvium, the tuff confining unit, and the lower carbonate aquifer. The borehole did not encounter significant sections of tuff confining unit rocks and did not reach the lower carbonate aquifer, which was deeper than expected here. However, both the piezometer strings and the slotted casing sections were successfully installed to provide isolated hydrologic access to the saturated alluvium and to water-producing zones within the welded Ammonia Tanks and Rainier Mesa Tuffs.

\subsubsection{Completion Method}

Caliper logs were used to calculate the volumes of stemming materials needed during well completion. Well-construction materials were inspected according to relevant procedures; standard decontamination procedures were employed to prevent the introduction of contaminants into the well. The filter pack around each open interval consists of $0.95-\mathrm{cm}(3 / 8-i n$.) by 4-mesh washed pea gravel, with 6-9 Colorado silica sand directly above the gravel, and 20/40 sand on top of the 6-9 sand. In this stemming design, developed by the UGTA project at the NTS, the layer of 20/40 sand serves as a barrier to any fluids that might seep from the cement above, preventing cement fluids from contaminating the groundwater (fluids from the cement would have the effect of drastically raising the $\mathrm{pH}$ level of the groundwater). The underlying layer of 
6-9 sand prevents the 20/40 sand from infiltrating the gravel-pack. All cement used in stemming the piezometer and production strings was type II Portland cement with no additives. A clearwater pre-flush and back-flush were made at each stage of emplacement. Gravel, sand, and cement were emplaced through a tremie line that was withdrawn as the completion process progressed. Stemming progress was monitored by means of a nuclear annulus investigation log ("NAIL log”). The as-built positions of the well materials are shown on Figure 2-2 and listed in Table 2-5.

Piezometer String \#1 was landed at the depth of $376.9 \mathrm{~m}(1,236.7 \mathrm{ft})$ prior to installation of the 13\% $/ 8$-in. surface casing. The surface casing was landed just above fill material at the depth of $374.8 \mathrm{~m}(1,229.6 \mathrm{ft})$, with the piezometer situated in the annulus between the casing and the borehole wall. The bottom of the casing was cemented, filling the annulus to the depth of approximately $319.4 \mathrm{~m}$ (1,048 ft). A 41/2-in. tremie line was inserted temporarily for continuing the emplacement of stemming materials around the piezometer string. An interval of 6-9 sand was placed on top of the cement, to the depth of $308.8 \mathrm{~m}(1,012 \mathrm{ft})$, and the gravel pack was emplaced on top of the 6-9 sand to the depth of $278.0 \mathrm{~m}(912 \mathrm{ft})$. Finally, 20/40 sand was placed on top of the gravel to the depth of $274.3 \mathrm{~m}$ (900 ft). The annulus is open above the 20/40 sand, to the depth of $19.8 \mathrm{~m}(65 \mathrm{ft})$, where the cement baskets on the surface casing are positioned. The borehole annulus was cemented from the cement baskets to the surface with type W-60 gypsum cement. and neat type II cement

After drilling was completed, the drillers inserted a 27/8-in. tremie line and then landed the second piezometer tubing string at the depth of $674.2 \mathrm{~m}(2,212.0 \mathrm{ft})$. The casing subcontractor landed the production casing at the depth of $777.6 \mathrm{~m}(2,551.3 \mathrm{ft})$, just above $14.3 \mathrm{~m}(47 \mathrm{ft})$ of fill at the bottom of the hole. Stemming materials were emplaced through the tremie line such that gravel packing was placed adjacent to the slotted intervals in both the tubing and the casing, and isolated by sand and cement from regions above and below. Gravel was placed on top of fill in the interval 780.0 to $733.3 \mathrm{~m}$ (2,559 to 2,406 ft), and capped with a sand barrier to the depth of $723.0 \mathrm{~m}(2,372 \mathrm{ft})$. The sand is capped with cement placed in 2 stages to the depth of $681.2 \mathrm{~m}$ $(2,235 \mathrm{ft})$. The second gravel interval was placed adjacent to the slotted interval of Piezometer String \#2 up to the depth of $616.9 \mathrm{~m}$ (2,024 ft). A sand pack was placed on top of the gravel, to the depth of $608.1 \mathrm{~m}$ (1,995 ft), followed by cement placed in 3 stages to the depth of $543.2 \mathrm{~m}$ $(1,782 \mathrm{ft})$. The third gravel pack was placed at 543.2 to $447.1 \mathrm{~m}(1,782$ to $1,467 \mathrm{ft})$, adjacent to the upper slotted casing interval, and topped with sand to the depth of $440.7 \mathrm{~m}(1,446 \mathrm{ft})$. The final cement cap was placed on top of the sand in 6 stages to the depth of $271.3 \mathrm{~m}(890 \mathrm{ft})$, approximately $11.3 \mathrm{~m}$ (37 ft) above the static fluid level in the well. 
The drill rig was released after cementing was completed. Hydrologic testing was planned as a separate effort (outside the scope of this report), so a pump was not installed in the well and no well-development or pumping tests were conducted immediately after completion.

\subsection{Actual Versus Planned Costs and Scheduling for Well ER-5-3}

The original BN cost model developed for Well ER-5-3 was based on drilling to the planned TD of 1,173.5 $\mathrm{m}(3,850 \mathrm{ft})$. The drilling program baseline projected that it would require 31 days to accomplish drilling of the surface and main holes, logging, and completion for the well, assuming the conductor hole would already have been constructed by BN. However, the actual conditions encountered during drilling of the borehole (severe borehole instability, which forced early termination of drilling) were measurably different from predicted conditions, so the baseline was changed during drilling.

The new cost model, based on a TD of $792.5 \mathrm{~m}(2,600 \mathrm{ft})$, estimated a total of 28 days to complete the well. It took 24 days to drill the main and surface holes, and install the completion string in Well ER-5-3, including 3 days for rig repairs and a safety stand down. A graphical comparison, by day, of planned and actual well-construction activities is presented in Figure 2-4.

The cost analysis for Well ER-5-3 begins with the cost of the move of the UDI drill rig from Well ER-EC-2a in Oasis Valley to the Well ER-5-3 site. The cost of building roads, the drill pad, and sumps is not included, and the cost of well-site support by IT is not included. The total construction cost for Well ER-5-3 includes all drilling costs: charges by the drilling subcontractor; charges by other support subcontractors (including compressor services, drilling fluids, bits, casing services, down-hole tools and, and geophysical logging); and charges by BN for mobilization and demobilization of equipment, partial construction of the conductor hole, cementing services, completion materials, radiation technicians, inspection services, and geotechnical consultation.

The total planned cost for Well ER-5-3, based on the new baseline, was $\$ 2,109,873$. The actual cost was $\$ 1,637,090$, or 22 percent less than the planned cost. Figure $2-5$ is a comparison of the planned (new baseline) and actual costs, by day, for drilling and completing Well ER-5-3. 


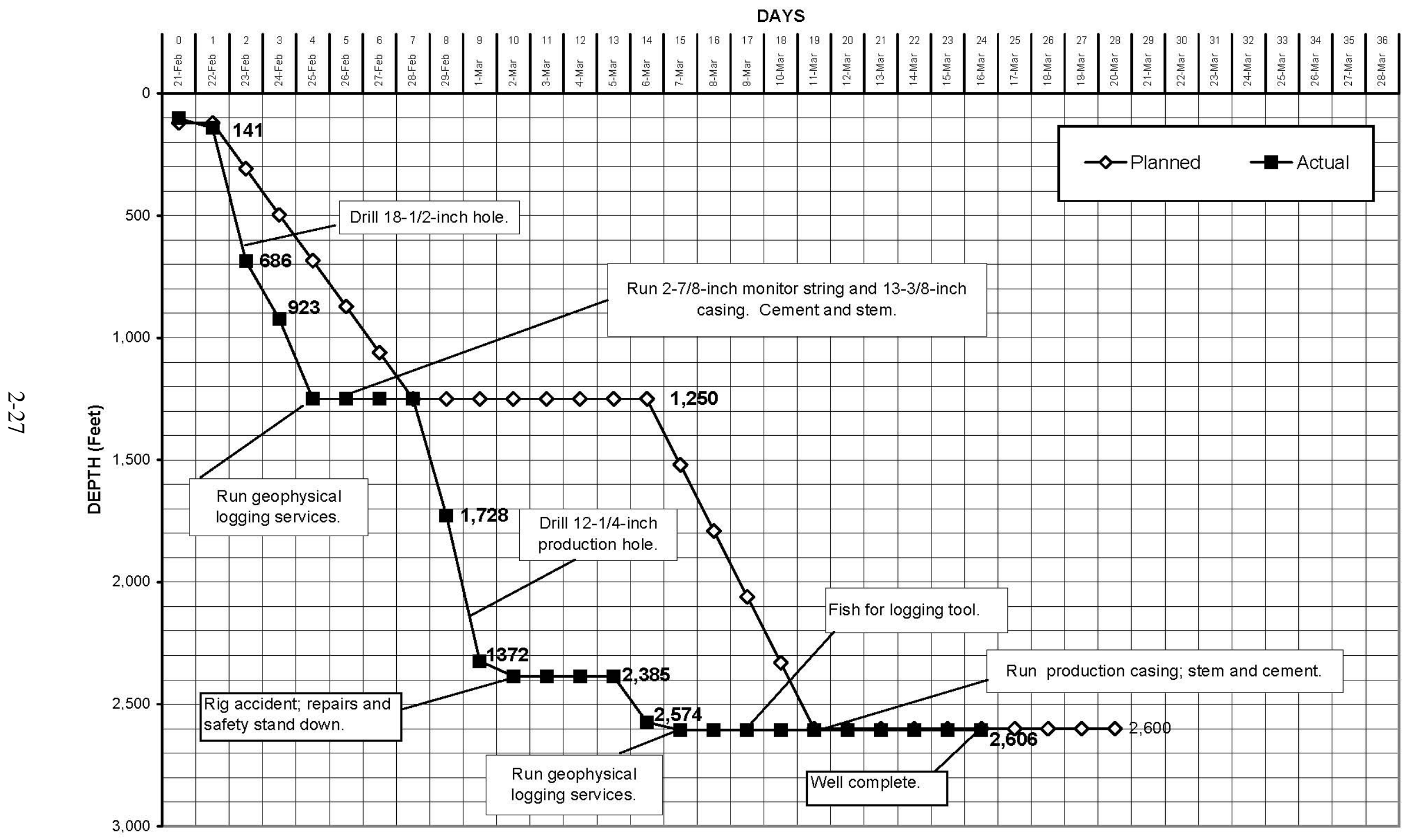

Figure 2-4

Planned versus Actual Construction Progress for Well ER-5-3 


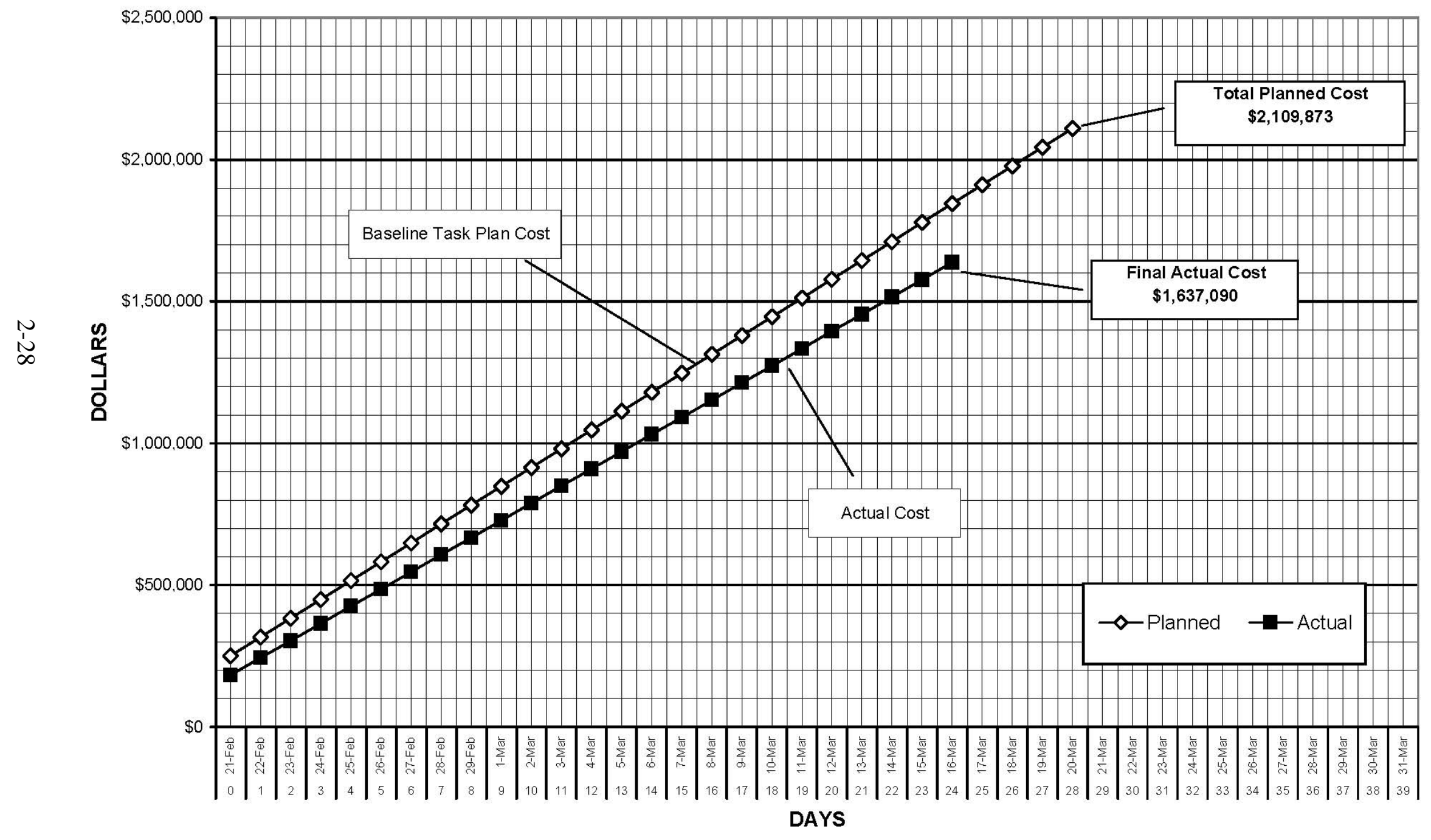

Figure 2-5

Planned versus Actual Cost for Constructing Well ER-5-3 


\subsection{Well ER-5-3\#2}

\subsection{Well-Specific Objectives}

The scientific objectives listed in Section 1.2 of this report also apply to Well ER-5-3\#2, the second well drilled in the cluster. Interpretations based on geologic samples, geophysical logging data, hydrologic data, and water samples from this well will be used to accomplish these objectives. The first well in the cluster, Well ER-5-3, did not reach the Paleozoic carbonate rocks as planned because the carbonate rocks are deeper than expected and because of drilling problems, so Well ER-5-3\#2 was designed to be drilled deep enough to reach the carbonate rocks.

\subsection{Drilling Summary}

This section contains detailed descriptions of the drilling process and fluid management issues.

\subsubsection{Introduction}

The general drilling requirements for construction of Well ER-5-3\#2 are given in Frenchman Flat Hydrogeologic Investigation Wells Drilling and Completion Criteria, Revisions 0 and 1 (IT, 2000a, 2001a). Specific requirements for Well Cluster ER-5-3 were outlined in Drilling Work Plan Number D-003-001.00 (BN, 2000b). The following information was compiled primarily from BN daily drilling reports. A summary of drilling statistics for the well is given in Table 3-1. Figure 3-1 is a chart of the drilling and completion history for Well ER-5-3\#2.

\subsubsection{Drilling History}

Field operations at Well ER-5-3\#2 began on March 16, 2000, when a BN drilling crew rigged up and used an auger rig to drill a 121.9-cm (48-in.) conductor hole from ground level to $30.5 \mathrm{~m}$

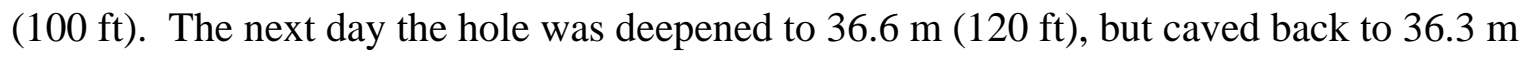
(119 ft). A string of 30-in. casing was set at $36.0 \mathrm{~m}$ (118 ft) below ground level. The bottom of the casing was cemented with neat type II cement, and the annulus was cemented to ground level with type II cement with 25 percent gypsum, topped off with neat type II cement. The BN drillers rigged down and moved the auger rig off location on March 18, 2000, as UDI started moving equipment from Well ER-5-3. The UDI crew spent March 18 to 22, 2000, rigging up the Wilson Mogul 42B drilling rig at Well ER-5-3\#2, and then assembled a center-punch BHA consisting of a 26-in. hole opener above a 171/2-in. bit. 


\section{Table 3-1 \\ Abridged Drill Hole Statistics for Well ER-5-3\#2}

\begin{tabular}{|c|c|}
\hline $\begin{array}{l}\text { LOCATION DATA: } \\
\text { Coordinates }{ }^{a}:\end{array}$ & $\begin{array}{llll}\text { Central Nevada State Planar: } & \text { NAD 83: N 6,235,789.9 m } & \text { E 564,855.2 m } \\
& \text { NAD 27: N 773,586.2 ft } & \text { E 713,036.9 ft } \\
& & \\
\text { Universal Transverse Mercator: } & \text { NAD 83: N 4,081,317.0 m } & \text { E 594,544.7 m } \\
3,334.3 \mathrm{~m}(1,016.3 \mathrm{ft}) & \text { (1929 National Geodetic Vertical Datum) }\end{array}$ \\
\hline \multicolumn{2}{|l|}{ DRILLING DATA: } \\
\hline Spud Date: & 3/23/2000 (main hole drilled with Wilson Mogul 42B rig) \\
\hline Total & $1,732.2 \mathrm{~m}(5,683 \mathrm{ft})$ \\
\hline Date TD Reached: & $5 / 04 / 2000$ \\
\hline \multicolumn{2}{|c|}{ Date Well Completed: 5/19/2000 } \\
\hline Date Well Recompleted: & $3 / 20 / 2001$ \\
\hline Hole Diameter: & 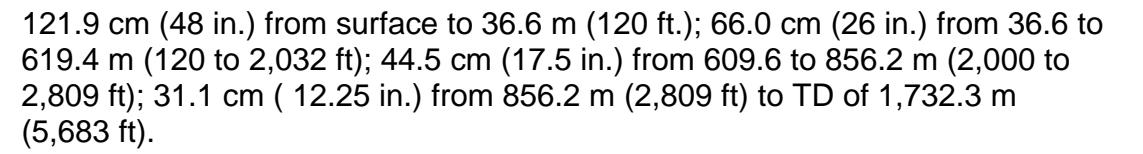 \\
\hline Drilling Techniques: & 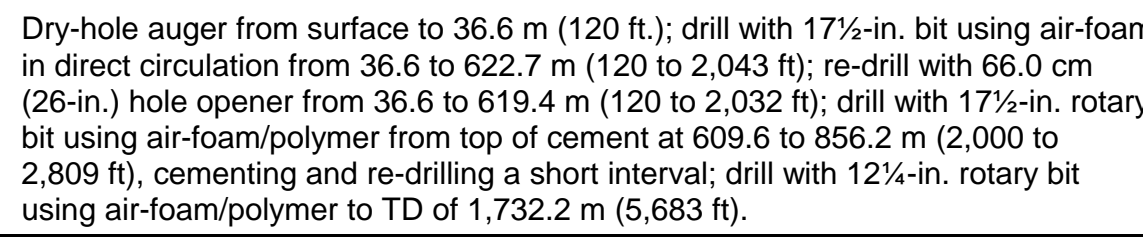 \\
\hline CASING D & $\begin{array}{l}\text { 30-in. conductor casing, surface to } 36.0 \mathrm{~m}(118 \mathrm{ft}) ; 20 \text {-in. surface casing, surface } \\
\text { to } 613.8 \mathrm{~m}(2,013.8 \mathrm{ft}) ; 133 / 8 \text {-in. intermediate casing, surface to } 849.0 \mathrm{~m} \\
(2,785.5 \mathrm{ft}) \text {. }\end{array}$ \\
\hline \multicolumn{2}{|c|}{$\begin{array}{l}\text { The completion string consists of } 75 / 8 \text {-in. carbon-steel casing connected to } 51 / 2 \text {-in. stainless-steel casing via } \\
\text { an internally coated carbon-steel cross-over sub. The } 75 / 8 \text {-in. casing has an internal epoxy coating from } 75.5 \\
\text { to } 754.3 \mathrm{~m}(247.9 \text { to } 2,474.7 \mathrm{ft}) \text {, and extends through the unsaturated zone approximately } 472.4 \mathrm{~m}(1,550 \mathrm{ft}) \\
\text { into the top of the saturated zone. The } 14.13-\mathrm{cm} \text { ( } 5.563 \text {-in.) outside-diameter completion casing has a } \\
12.819-\mathrm{cm} \text { ( } 5.047 \text {-in.) inside diameter, is bull-nosed, and has } 1 \text { slotted interval (see below) that consists of } \\
8 \text { consecutive slotted joints. During recompletion activities, the upper slots that allowed communication with } \\
\text { the tuff confining unit were sealed with cement, and the lower slots were opened to allow access to the lower } \\
\text { carbonate aquifer. Detailed data for the completion intervals are provided in Section } 3.6 .2 \text { of this report. }\end{array}$} \\
\hline
\end{tabular}

Total Depth:

$1,496.0 \mathrm{~m}(4,908.2 \mathrm{ft})$

Depth of Slotted Section:

$$
\begin{aligned}
& \text { Slots sealed with cement: } \\
& \begin{array}{l}
1,390.9 \text { to } 1,426.5 \mathrm{~m} \\
(4,563.3 \text { to } 4,680.0 \mathrm{ft})
\end{array}
\end{aligned}
$$

Slots open:

$1,426.5$ to $1,495.4 \mathrm{~m}$

$(4,680.0$ to $4,906.1 \mathrm{ft})$

Depth of Sand Packs: None

Depth of Gravel Packs: None

Depth of Pump:

None installed at time of recompletion.

Water Depth ${ }^{\text {b. }}$

$282.5 \mathrm{~m}(927.0 \mathrm{ft})$

DRILLING CONTRACTOR: United Drilling, Inc.

GEOPHYSICAL LOGS BY: Schlumberger Logging Services, Colog, Inc. Desert Research Institute, Gyrodata

SURVEYING CONTRACTOR: Bechtel Nevada

a As-built coordinates and elevation measured by BN Survey.

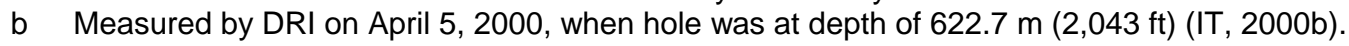




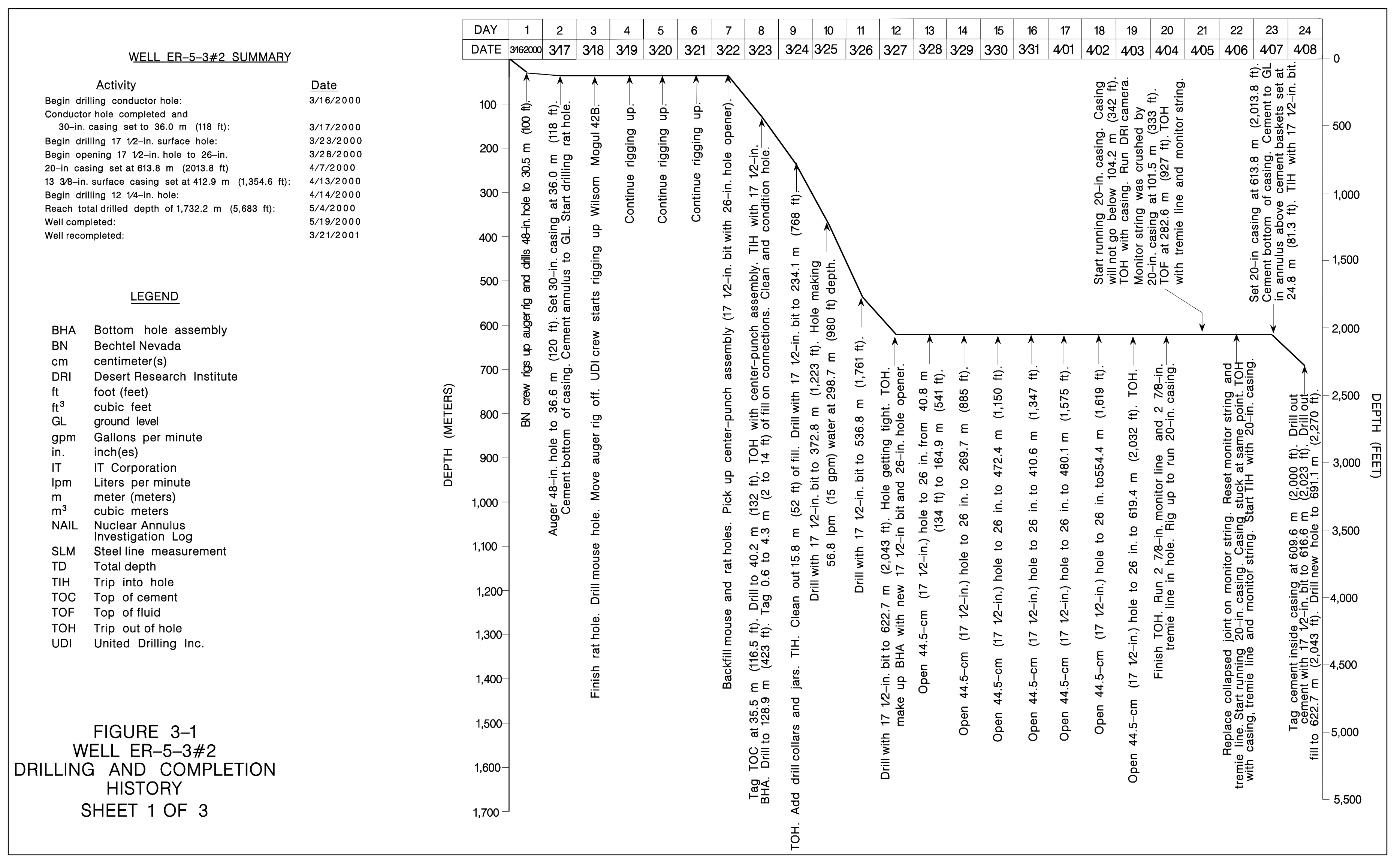




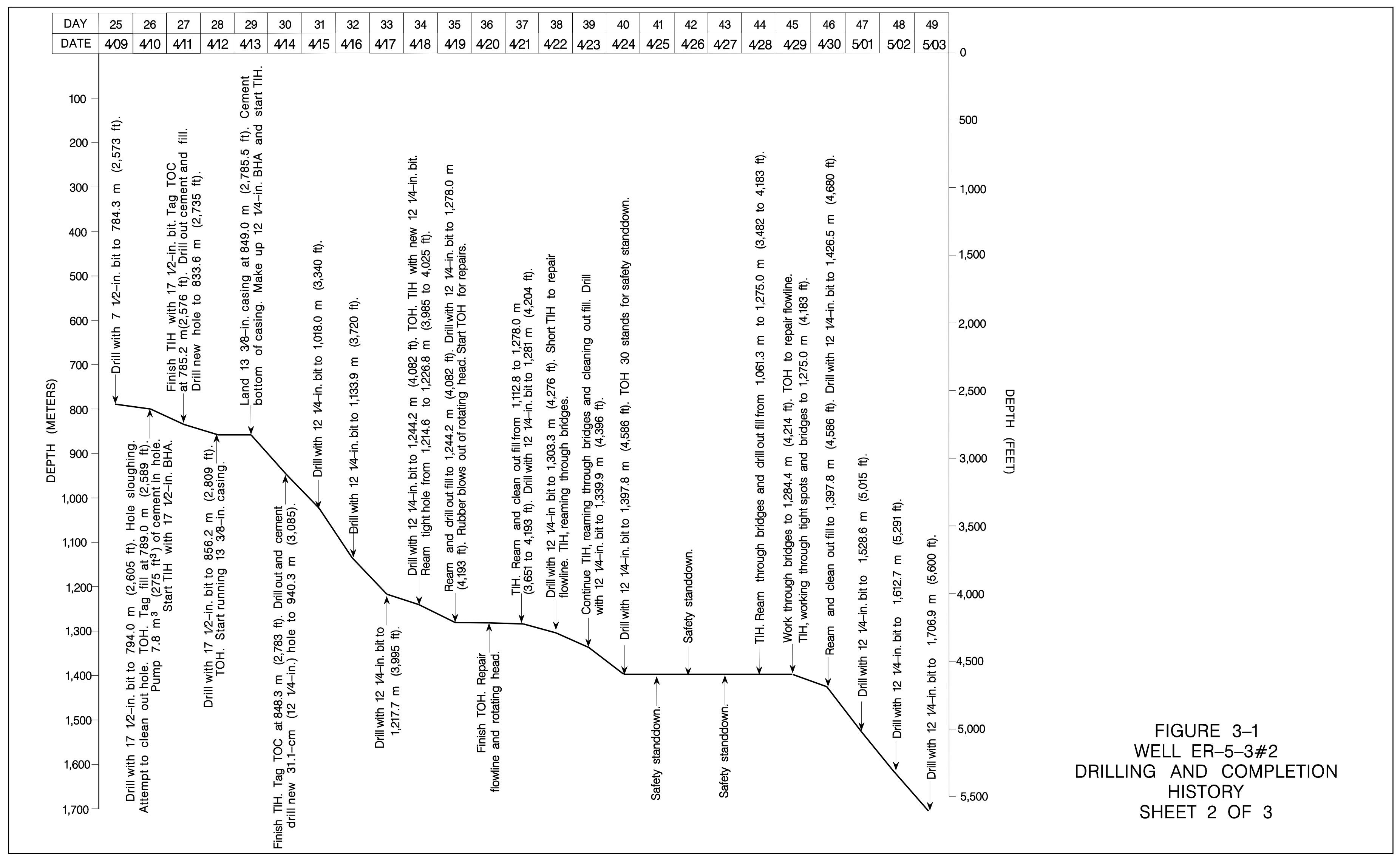




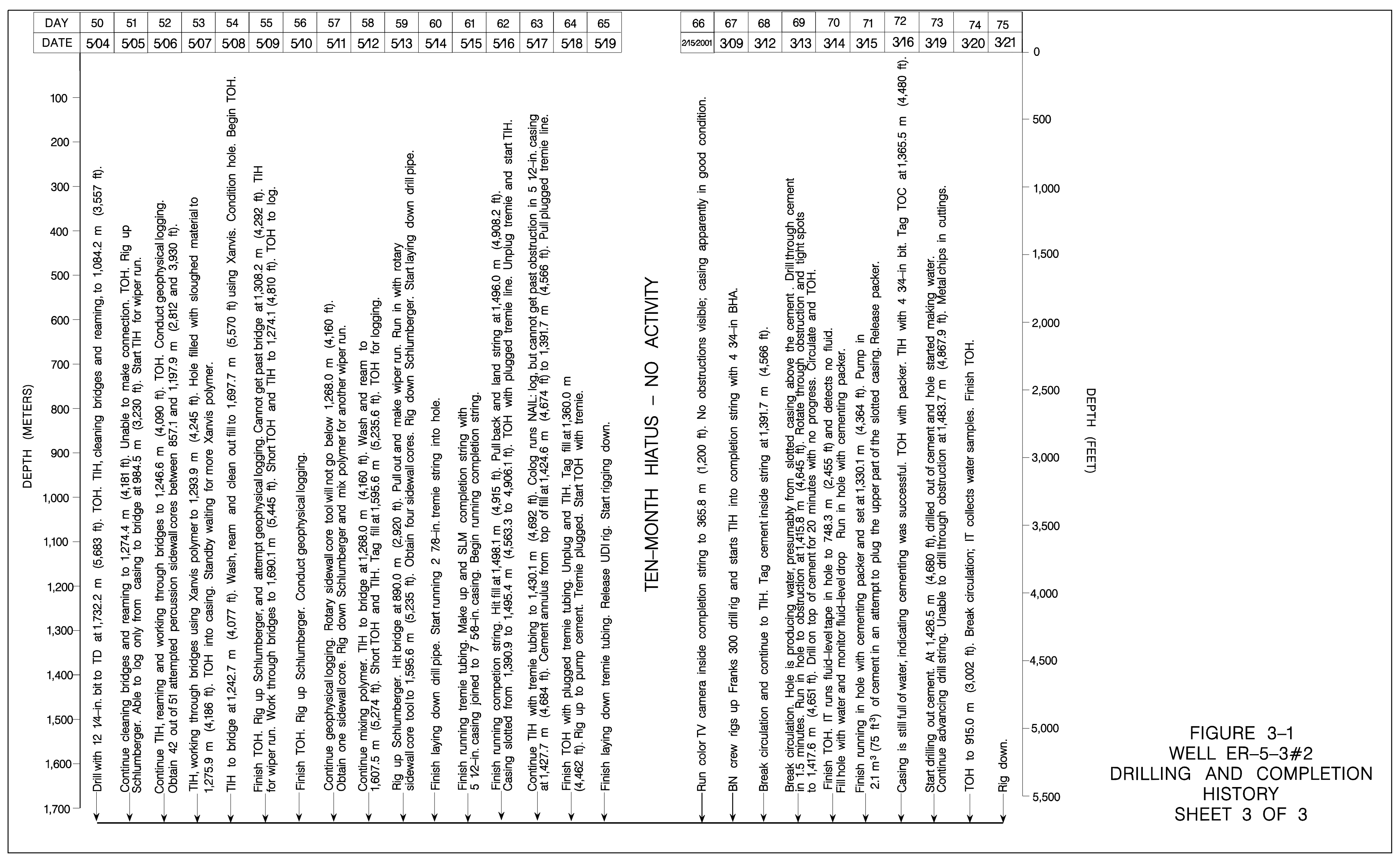


This page intentionally left blank. 
Drilling of the surface hole for Well ER-5-3\#2 started on March 23, 2000, when the drillers lowered the center-punch assembly in the hole and tagged cement at $35.5 \mathrm{~m}(116.5 \mathrm{ft})$. They drilled through the cement and continued until the 171/2-in. bit was at a depth of $40.2 \mathrm{~m}$ (132 ft), and the 26-in. bit was near the bottom of the casing. The center-punch assembly was then removed from the hole, and a 171/2-in. BHA was made up using the same 171/2-in. bit. Drilling of the surface hole continued, with air-foam and a polymer additive as the drilling fluid. Approximately 0.6 to $4.3 \mathrm{~m}$ (2 to $14 \mathrm{ft}$ ) of fill was encountered on connections. The BHA was removed from the hole after reaching a depth of $128.9 \mathrm{~m}$ (423 ft) in order to add drill collars and jars. When the bit was lowered back into the hole, $15.8 \mathrm{~m}$ (52 ft) of fill had accumulated. After the fill was cleaned out, drilling continued, with as much as $3.7 \mathrm{~m}(12 \mathrm{ft})$ of fill encountered on connections. IT personnel estimated that the hole was producing about $56.8 \mathrm{lpm}(15 \mathrm{gpm})$ of water at a depth of $284.7 \mathrm{~m}$ (934 ft).

At a depth of $622.7 \mathrm{~m}$ (2,043 ft), on March 27, 2000, the hole became tight, so it was decided to stop and set surface casing as a precaution against further degradation of the borehole wall. A new 171/2-in. button bit was installed below a 26-in. hole opener, and the next $6 \frac{1}{2}$ days were spent opening the 44.5-cm (17.5-in.) hole to a diameter of $66.0 \mathrm{~cm}$ (26 in.) to the depth of $619.4 \mathrm{~m}(2,032 \mathrm{ft})(171 / 2-$ in. bit at $622.7 \mathrm{~m}$ [2,043 ft]). Geophysical logging was not conducted before installation of the casing, but the drillers circulated and cleaned out the hole before the 20-in. surface casing was installed.

First, the casing subcontractor landed a $27 / 8$-in. stainless-steel piezometer string at the depth of $604.8 \mathrm{~m}(1,984.3 \mathrm{ft})$. This tubing was hung on the 30 -in. conductor casing, and a $27 / 8$-in. tremie line was also run in the hole to the depth of $424.4 \mathrm{~m}$ (1,392.5 ft) to aid in stemming around the piezometer string. On the first attempt to insert the surface casing, the 20-in. casing would not go below the depth of $104.2 \mathrm{~m}$ (342 ft). Thirteen joints of tremie tubing were pulled up for inspection, found to be in good condition, and re-hung at the same point. Then DRI ran a down-

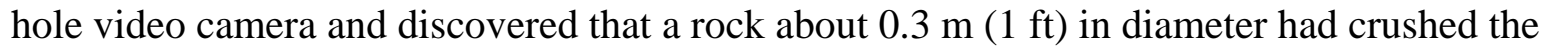
piezometer string at a depth of $101.5 \mathrm{~m}$ (333 ft). The tremie line and the piezometer string were then removed from the hole, and the damaged joint was replaced. After the piezometer string was run back into the hole and landed at $604.8 \mathrm{~m}$ (1,984.3 ft), DRI ran the down-hole video camera again and verified its placement. The tremie line was rerun, and the casing crew began a second attempt to run the 20-in. casing. Again they were unable to advance the casing past the depth of $104.2 \mathrm{~m}$ (342 ft), so all casing and tubing was removed from the hole. Finally, attempts to install the piezometer string were abandoned, and the casing crew began to run the 20-in. casing into the hole. After working through tight spots at $103.9 \mathrm{~m}$ (341 ft), $140.2 \mathrm{~m}$ (460 ft) and

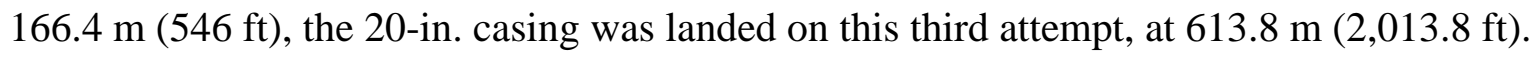


Cement baskets on the 20-in. casing are located at $24.8 \mathrm{~m}(81.3 \mathrm{ft})$ below ground level, and a stab-in shoe (for cementing) was positioned near the bottom of the first joint at $641.0 \mathrm{~m}$ $(2,013 \mathrm{ft})$. The bottom of the surface casing was cemented by pumping neat type II cement through the stab-in shoe. The cement is estimated to have risen to a depth of $528.2 \mathrm{~m}(1,733 \mathrm{ft})$ in the annulus of the 20-in. casing. A mix of cement, cedar fiber, sand, and gravel was placed on top of the cement baskets, and the annulus above the baskets was then cemented to ground level on April 7, 2000.

After installation of the casing the drillers made up a new 171/2-in. BHA; they tagged cement at

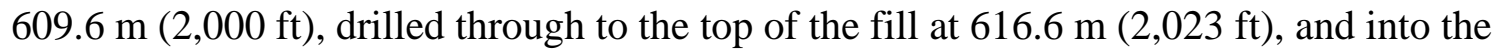

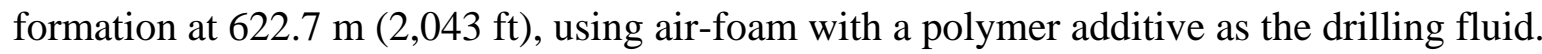
Drilling continued without significant problems until the hole became tight and started sloughing at the depth of $786.4 \mathrm{~m}(2,580 \mathrm{ft})$. Drilling continued, but after stopping to make a connection at $794.0 \mathrm{~m}$ (2,605 ft), the drillers had to make several attempts to clean out the hole, encountering 4.6 to $6.1 \mathrm{~m}$ (15 to $20 \mathrm{ft}$ ) of fill on each wiper run. It was decided to cement the lower portion of the hole in an attempt to stabilize it. The hole was allowed to settle, then a string of 5-in. drill pipe was run in, tagging fill at $789.1 \mathrm{~m}(2,589 \mathrm{ft})$. A small batch of cement was pumped down the drill pipe, which was then removed. When the 171/2-in. BHA was lowered back into the borehole it tagged cement at $785.2 \mathrm{~m}(2,576 \mathrm{ft})$. Cement and fill were drilled out and drilling of

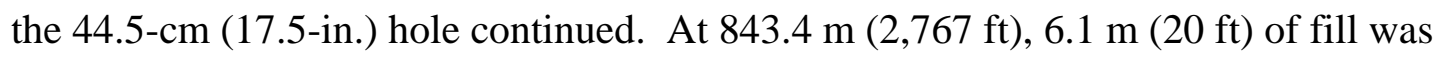
encountered during a connection. At $856.2 \mathrm{~m}$ (2,809 ft), a compressor broke down, and drilling ceased. After circulating for half an hour, fill was tagged at $850.4 \mathrm{~m}$ (2,790 ft), and the 171/2-in. BHA was pulled out in preparation for running the $13 \% 3$-in. intermediate casing.

BN workers welded a stab-in shoe to the first joint of $13 \%$-in. casing, and centralizers were positioned at the middle of the first joint and on the collars of the first 3 joints. The casing subcontractor landed the 13\%3-in. casing at $849.0 \mathrm{~m}$ (2,785.5 ft) on April 13, 2000, then a string of 5-in. drill pipe was inserted in the stab-in shoe to cement the bottom of the casing with neat type II cement. The top of the cement in the annulus of the $133 / 8$-in. casing was later estimated from geophysical logs to be at the depth of $777.2 \mathrm{~m}(2,550 \mathrm{ft})$.

The drillers made up and lowered a 121/4-in. BHA into the hole, and tagged cement at $848.3 \mathrm{~m}$ $(2,783 \mathrm{ft})$ inside the $13 \%$-in. casing. Drilling of the 31.1-cm (12.25-in.) main hole began on April 14, 2000, and continued with no fill on connections until drilling was stopped at a depth of 1,244.2 m (4,082 ft) on April 18, 2000, to replace the bit and repair the flow-line. Tight spots were encountered when the new 121/4-in. button bit was run into the hole and the hole had to be 
reamed from 1,226.8 to 1,235.0 m (4,025 to 4,052 ft). A 9.1-m (30-ft) interval of sloughed material was encountered between $1,235.0$ and 1,244.2 m (4,052 to 4,082 ft).

Drilling of the 31.1-cm (12.25-in.) main hole continued to be difficult. At the depth of 1,275.0 m $(4,183 \mathrm{ft})$, the flow-line again needed repair so the drillers pulled the bit a short distance off the bottom of the hole. About $13.1 \mathrm{~m}$ ( $43 \mathrm{ft}$ ) of fill was encountered as the bit was lowered to the bottom after a hiatus of about 2.5 hrs. But only $3.0 \mathrm{~m}$ (10 ft) new hole was drilled before the rubber blew out of the rotating head on April 19, 2000, and the drill string was again removed from the hole. During a hiatus of 24.5 hours the crew rebuilt the flow-line and replaced the rotating head. The crew had to ream and drill through fill and bridges (areas where only short sections of the hole were blocked by sloughed material) as they lowered the BHA back into the hole. Drilling of the 31.1-cm (12.25-in.) hole continued, with 1 more trip of the pipe up into the casing shoe to repair the flow-line, followed by reaming and cleaning out fill back to bottom. The hole reached a depth of 1,397.8 m (4,586 ft) on April 24, 2000.

A safety stand-down was initiated on April 24, 2000, because the blow-out of the rotating head rubber on April 19, 2000, was considered to be a near-miss incident. The BHA was again pulled up into the casing during this drilling hiatus, which lasted for 80.5 hours.

Operations resumed on April 28, 2000, when the drillers started lowering the 121/4-in. BHA back

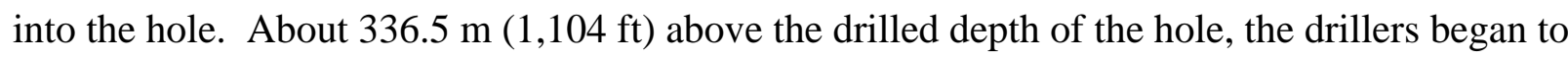
encounter bridges, and had to ream and clean out fill. The drill string had been advanced to a point about $113.4 \mathrm{~m}$ (372 ft) above the drilled depth of the hole, when the flow-line again developed a leak, necessitating another partial trip out to repair it. The drillers again lowered the bit back to the depth of 1,160.4 $\mathrm{m}$ (3,807 ft), and again began working through bridges, cleaning out fill and reaming back to the bottom of the hole. Altogether, 62 hours were spent getting the bit back to the bottom of the hole after the safety stand down.

On April 30, 2000, drilling of new 31.1-cm (12.25-in.) hole resumed and continued with no significant problems until a TD of 1,732.2 m (5,683 ft) was reached on May 4, 2000. The TD was $573.9 \mathrm{~m}(1,883 \mathrm{ft})$ deeper than the planned TD for Well ER-5-3 $(1,158.2 \mathrm{~m}[3,800 \mathrm{ft}])$ because the top of Paleozoic rocks, a prime objective for this second well, was $328.6 \mathrm{~m}(1,078 \mathrm{ft})$ deeper than anticipated. After reaching TD, the drillers cleaned and reamed the hole, but got stuck for 3 hours at a depth of 1,271.3 m (4,171 ft) and afterward were unable to make a connection at 1,274.4 $\mathrm{m}(4,181 \mathrm{ft})$. The drill string was then removed for geophysical logging, passing through 3 tight spots on the way out. 
On May 5, 2000, Schlumberger rigged up and began geophysical logging. Five separate attempts to obtain logs and sidewall cores were made, with varying degrees of success, May 5 to 13, 2000. In most of these attempts, sufficient depths could not be reached due to bridges in the hole. Five wiper runs were made with the 121/4-in. bit to clean out the borehole between each logging attempt, and using a more viscous polymer mud for the last 4 runs.

Installation of the completion string began on May 14, 2000, but the 51/2-in. casing could only be advanced to the depth of 1,496.0 m (4,908.2 ft), and was cemented in place. Demobilization of the UDI rig from the Well ER-5-3\#2 site began on May 19, 2000.

After a 10-month hiatus in activity, the well was recompleted on March 9 to 21, 2001, by a BN crew using the Franks 300 drill rig. See Section 3.6.4.2 for a description of recompletion activities at Well ER-5-3\#2. The directional survey run in Well ER-5-3\#2 on May 11, 2001 (after the well was recompleted) indicates that at the lowest surveyed depth of 1,490 m (4,890 ft) the hole had drifted $45.1 \mathrm{~m}(148.1 \mathrm{ft})$ to the north of the collar location, and that the hole is relatively straight (no “dog legs”).

A graphical depiction of drilling parameters including penetration rate, revolutions per minute, pump pressure, and weight on the bit is presented in Appendix A-1. See Appendix A-2 for a listing of casing materials. Drilling fluids and cements used in Well ER-5-3\#2 are listed in Appendix A-3.

\subsubsection{Drilling Problems}

As described in detail above, borehole instability was the primary drilling problem at Well ER-5-3\#2, starting below the depth of $622.7 \mathrm{~m}$ (2,043 ft), near the bottom of the alluvium section. After this interval was cased off, drilling continued relatively smoothly (though frequently encountering some sloughing) to the depth of about $794.0 \mathrm{~m}(2,605 \mathrm{ft})$. At this point the bottom of the borehole was cemented and drilling continued to the depth of $856.2 \mathrm{~m}$ (2,809 ft), where high water production and continued problems with sloughing prompted the decision to install a string of intermediate casing. Borehole sloughing continued to be a problem as the hole was advanced through zeolitic nonwelded and bedded tuffs to the depth of 1,397.8 $\mathrm{m}$ (4,586 ft). After an 80-hour safety stand down at that depth, several days were spent getting back to the drilled depth through the continually accumulating sloughed material. No significant problems were encountered while drilling through the lower $28 \mathrm{~m}(92 \mathrm{ft})$ of the tuff section and the $306.3 \mathrm{~m}(1,005 \mathrm{ft})$ of dolomite penetrated below the tuffs. 


\subsubsection{Fluid Management}

Drilling effluent was monitored according to the methods prescribed in the UGTA FMP (DOE, 1999). The air-foam/polymer drill fluid was circulated down the inside of the drill string and back up the hole through the annulus (conventional or direct circulation) and then discharged into a sump. Water used to prepare drilling fluids came from Wells 5, 5b, and C-1. Lithium bromide was added to the drill fluid as a tracer to provide a means of estimating groundwater production based on dilution of $\mathrm{LiBr}$ in the return fluid.

As described in Section 2.3.3, two unlined sumps were constructed to handle the expected high water production during construction of this well cluster (Figure 2-1). For drilling of Well ER-5-3\#2, a second overflow pipe was added to Sump \#1, and an equalizing pipe was added between Sumps \#1 and \#2. All fluids from Well ER-5-3\#2 were discharged to Sump \#2.

Samples of drilling effluent were tested onsite hourly for the presence of tritium, and every 8 hours for lead. The onsite monitoring results indicate that tritium remained at background levels, and lead was undetectable (less than 50 parts per billion) during the entire drilling operation (IT, 2000b). Fluid samples were collected from both sumps during drilling and after drilling was completed to demonstrate compliance with the FMP. The analytical results showed the sump fluids were within the parameters of the FMP criteria (IT, 2000b). Water-quality data for all 4 samples are given in Appendix B.

The results of analyses of samples of drilling fluid collected at Well ER-5-3\#2 during drilling operations indicate that all fluid quality objectives were met, as shown on the fluid management reporting form dated form dated September 21, 2001 (Appendix B). The form lists volumes of solids (drill cuttings) and fluids produced during well-construction operations, Phase I, vadoseand saturated-zone drilling. (The form also includes data for Phase II, well development and aquifer testing, conducted later and not addressed in this report.) The volume of solids produced in Phase I drilling was calculated using the diameter of the borehole (from caliper logs) and the depth drilled, and includes added volume attributed to a rock bulking factor. The volumes of fluids listed on the report are estimates of total fluid production, and do not account for evaporation of fluids from the sumps.

\subsection{Geologic Data Collection}

This section describes the sources of geologic data obtained from Well ER-5-3\#2 and the methods of data collection. Improving the understanding of the subsurface stratigraphy, obtaining data to better quantify physical and mineralogical changes in the alluvium with depth, 
and obtaining velocity and geologic control to aid interpretation of surface seismic data were among the objectives for drilling Well ER-5-3\#2, so the proper collection of geologic and hydrogeologic data from the well was considered fundamental to successful completion of the project.

Geologic data collected at Well ER-5-3\#2 consist of drill cuttings, sidewall samples, and geophysical logs. Data collection, sampling, transfer, and documentation activities were performed according to applicable contractor procedures.

\subsubsection{Collection of Drill Cuttings}

Composite drill cuttings were collected from Well ER-5-3\#2 at 3-m (10-ft) intervals as drilling progressed from the depth of $36.6 \mathrm{~m}(120 \mathrm{ft})$ to the TD of the hole at 1,732.3 $\mathrm{m}(5,683 \mathrm{ft})$. Triplicate 550-cc (1-pint) samples were collected from 555 intervals. These samples are stored under secure, environmentally controlled conditions at the USGS Geologic Data Center and Core Library in Mercury, Nevada. One of these sample sets was sealed with custody tape at the rig site and remains sealed as an archive sample; one set was left unsealed in the original sample containers; and the third set was washed and stored according to standard USGS Core Library procedures. The washed set was used by BN to construct the detailed lithologic log presented in Appendix C-2. The IT field representative collected 2 additional sets of reference samples from each of the cuttings intervals. One reference set was examined at the drill site for use in preparing field lithologic descriptions, and remains in the custody of SN-JV. The other set remains at LANL where it was sent for petrographic, mineralogic, and chemical analyses.

\subsubsection{Sidewall Core Samples}

Sidewall core samples were collected by Schlumberger from Well ER-5-3\#2 to verify the stratigraphy and lithology at selected locations below the depth of $853.4 \mathrm{~m}(2,800 \mathrm{ft})$. Sample locations were selected by the IT field representative on the basis of field lithologic logs (with consideration of borehole conditions determined from caliper logs). A percussion gun tool was used to collect 39 sidewall cores in the tuff section, and a mechanical (rotary) coring tool was used to collect 3 samples in the tuff section and 2 in the dolomite. Table 3-2 lists the recovery and stratigraphic assignment for each sample. 
Table 3-2

Sidewall Samples from Well ER-5-3\#2

\begin{tabular}{|c|c|c|c|}
\hline $\begin{array}{l}\text { Core Depth } \\
\text { meters (feet) }\end{array}$ & $\begin{array}{c}\text { Tool } \\
\text { Used }^{a}\end{array}$ & $\begin{array}{c}\text { Recovery } \\
\text { (percent) }\end{array}$ & Stratigraphic Unit ${ }^{c}$ \\
\hline $857.1(2,812)$ & S-Gun & 25 & Tuff of Holmes Road \\
\hline $923.5(3,030)$ & S-Gun & 25 & Calico Hills Formation \\
\hline $938.8(3,080)$ & S-Gun & 25 & \multirow{11}{*}{ Wahmonie Formation } \\
\hline $943.4(3,095)$ & S-Gun & 50 & \\
\hline $947.9(3,110)$ & S-Gun & 60 & \\
\hline $957.1(3,140)$ & S-Gun & 50 & \\
\hline $963.2(3,160)$ & S-Gun & 60 & \\
\hline $975.4(3,200)$ & S-Gun & 15 & \\
\hline $986.0(3,235)$ & S-Gun & 50 & \\
\hline $990.6(3,250)$ & S-Gun & 50 & \\
\hline $1,000.1(3,281)$ & S-Gun & 25 & \\
\hline $1,006.5(3,302)$ & S-Gun & 40 & \\
\hline $1,008.9(3,310)$ & S-Gun & 90 & \\
\hline $1,018.0(3,340)$ & S-Gun & 50 & \\
\hline $1,027.2(3,370)$ & S-Gun & 80 & \\
\hline $1,035.1(3,396)$ & S-Gun & 100 & \\
\hline $1,038.2(3,406)$ & S-Gun & 75 & \\
\hline $1,043.3(3,423)$ & S-Gun & 100 & Salyer Member, \\
\hline $1,045.5(3,430)$ & S-Gun & 60 & monis \\
\hline $1,056.7(3,467)$ & S-Gun & 100 & \\
\hline $1,064.4(3,492)$ & S-Gun & 75 & \\
\hline $1,068.3(3,505)$ & S-Gun & 75 & \\
\hline $1,073.8(3,523)$ & S-Gun & 60 & \\
\hline $1,077.8(3,536)$ & S-Gun & 70 & \\
\hline
\end{tabular}

\begin{tabular}{|c|c|c|c|}
\hline $\begin{array}{l}\text { Core Depth } \\
\text { meters (feet) } \\
\end{array}$ & $\begin{array}{c}\text { Tool } \\
\text { Used }^{a} \\
\end{array}$ & $\begin{array}{c}\text { Recovery } \\
\text { (percent) } \\
\end{array}$ & Stratigraphic Unit ${ }^{c}$ \\
\hline $1,082.0(2,550)$ & S-Gun & 90 & \\
\hline $1,090.3(3,577)$ & S-Gun & 100 & \multirow{12}{*}{$\begin{array}{c}\text { Salyer Member, } \\
\text { Wahmonie Formation }\end{array}$} \\
\hline 1,093.0 (3,586) & S-Gun & 75 & \\
\hline $1,097.3(3,600)$ & S-Gun & 80 & \\
\hline $1,103.4(3,620)$ & S-Gun & 80 & \\
\hline $1,106.4(3,630)$ & S-Gun & 50 & \\
\hline $1,108.3(3,636)$ & S-Gun & 30 & \\
\hline $1,113.4(3,653)$ & S-Gun & 50 & \\
\hline $1,123.2(3,685)$ & S-Gun & 65 & \\
\hline $1,131.1(3,711)$ & S-Gun & 65 & \\
\hline $1,138.4(3,735)$ & S-Gun & 90 & \\
\hline $1,143.0(3,750)$ & S-Gun & 100 & \\
\hline $1,153.7(3,785)$ & S-Gun & 90 & \\
\hline $1,169.2(3,836)$ & S-Gun & 75 & \multirow{8}{*}{ Bullfrog Tuff } \\
\hline $1,182.0(3,878)$ & S-Gun & 25 & \\
\hline $1,184.2(3,885)$ & S-Gun & 25 & \\
\hline $1,191.8(3,910)$ & S-Gun & 25 & \\
\hline $1,191.8(3,910)$ & MCT & 75 & \\
\hline $1,197.9(3,930)$ & S-Gun & 25 & \\
\hline $1,213.1(3,980)$ & MCT & 83 & \\
\hline $1,401.2(4,597)$ & MCT & 63 & \\
\hline $1,428.0(4,685)$ & MCT & 88 & \multirow{2}{*}{$\begin{array}{c}\text { Paleozoic rocks, } \\
\text { undivided }\end{array}$} \\
\hline $1,443.8(4,737)$ & $\mathrm{MCT}$ & 75 & \\
\hline
\end{tabular}

a S-Gun = Percussion sidewall gun operated by Schlumberger; MCT = rotary mechanical sidewall coring tool operated by Schlumberger.

b Estimated.

c See detailed lithologic descriptions for these units in Appendix C-2. 


\subsubsection{Sample Analysis}

Twenty-two samples of drill cuttings from various depth in Well ER-5-3\#2 were submitted to the LANL Earth and Environmental Sciences Division - Geology and Geochemistry laboratories for petrographic, mineralogic, and chemical analyses to aid in stratigraphic identification and for characterization of mineral alteration. As shown on Table 3-3, all planned analyses were completed. The results of these analyses were reported by Warren (2000) and have been incorporated into the BN geologic interpretation presented in Section 5.0.

\subsubsection{Geophysical Logging Data}

Geophysical logs were run to further characterize the lithology, structure, and physical properties of the rocks encountered. In addition, logs were run to evaluate borehole conditions, to determine the fluid levels during the course of drilling, and to monitor completion progress. Geophysical logging was conducted only after the TD of the well had been reached, so no log data are available for the cased portion of the borehole. Thus, no open-hole geophysical log data were obtained in the depth interval 780.3 to $849.2 \mathrm{~m}$ (2,560 to 2,786 ft) at the well cluster site. A complete listing of the logs, dates run, depths, and service companies is provided in Table 3-4 (compare with logs run in Well ER-5-3, listed in Table 2-4). All the logs are available from BN in Mercury, NV, and copies are on file at the SN-JV office in Las Vegas, NV. Preliminary geophysical log data are reproduced in Appendix D.

The overall quality of the geophysical data collected was good, however, between the depths of about 850.4 and 1,425.9 m (2,790 and 4,678 ft) data acquisition was hampered by poor borehole conditions (wash-outs and bridges). Thermal flow and chemistry logs typically run by DRI were not run in this well due to the presence of high viscosity polymer drill fluid. 
Table 3-3

Status of Rock Sample Analyses for Well ER-5-3\#2

\begin{tabular}{|c|c|c|c|c|c|c|}
\hline \multirow{3}{*}{$\begin{array}{l}\text { Depth }^{\mathbf{a}} \\
\text { meters (feet) }\end{array}$} & \multirow{3}{*}{$\begin{array}{l}\text { Sample } \\
\text { Type }^{\text {b }}\end{array}$} & \multicolumn{5}{|c|}{ Analyses Performed $^{\mathrm{c}}$} \\
\hline & & \multirow{2}{*}{$\begin{array}{c}\text { Petrographic } \\
\text { PTS } \\
\end{array}$} & \multicolumn{2}{|c|}{ Mineralogic } & \multicolumn{2}{|c|}{ Chemical } \\
\hline & & & MP & XRD & XRF & $\mathrm{Fe}^{+2} / \mathrm{Fe}^{+3}$ \\
\hline $213.4(700)$ & DC & $\mathrm{C}$ & -- & $\mathrm{C}$ & $\mathrm{C}$ & $\mathrm{C}$ \\
\hline $780.3(2,560)$ & DC & C & -- & $\mathrm{C}$ & C & C \\
\hline $853.4(2,800)$ & $\mathrm{DC}$ & $\mathrm{C}$ & -- & $\mathrm{C}$ & C & C \\
\hline $871.7(2,860)$ & DC & C & -- & C & C & C \\
\hline $880.9(2,890)$ & $\mathrm{DC}$ & C & -- & $\mathrm{C}$ & C & $\mathrm{C}$ \\
\hline $902.2(2,960)$ & $\mathrm{DC}$ & C & -- & C & $\mathrm{C}$ & C \\
\hline $929.6(3,050)$ & DC & C & -- & $\mathrm{C}$ & $\mathrm{C}$ & $\mathrm{C}$ \\
\hline $966.2(3,170)$ & $\mathrm{DC}$ & C & -- & C & C & C \\
\hline $996.7(3,270)$ & DC & $\mathrm{C}$ & -- & $\mathrm{C}$ & C & C \\
\hline $1,018.0(3,340)$ & $\mathrm{DC}$ & C & -- & C & $\mathrm{C}$ & C \\
\hline $1,063.8(3,490)$ & $\mathrm{DC}$ & C & -- & $\mathrm{C}$ & C & C \\
\hline $1,085.8(3,560)$ & DC & $\mathrm{C}$ & -- & $\mathrm{C}$ & C & $\mathrm{C}$ \\
\hline $1,106.4(3,630)$ & DC & C & -- & C & $\mathrm{C}$ & C \\
\hline $1,143.0(3,750)$ & $\mathrm{DC}$ & $\mathrm{C}$ & -- & $\mathrm{C}$ & $\mathrm{C}$ & $\mathrm{C}$ \\
\hline $1,188.7(3,900)$ & $\mathrm{DC}$ & C & -- & C & C & C \\
\hline $1,204.0(3,950)$ & $\mathrm{DC}$ & C & -- & $\mathrm{C}$ & C & $\mathrm{C}$ \\
\hline $1,359.4(4,460)$ & DC & $\mathrm{C}$ & -- & $\mathrm{C}$ & $\mathrm{C}$ & $\mathrm{C}$ \\
\hline $1,401.0(4,596.5)$ & SC & C & -- & -- & -- & -- \\
\hline $1,408.2(4,620)$ & DC & C & -- & C & $\mathrm{C}$ & -- \\
\hline $1,423.4(4,670)$ & $\mathrm{DC}$ & C & -- & C & C & C \\
\hline $1,428.0(4,685)$ & $\mathrm{SC}$ & $\mathrm{C}$ & -- & -- & -- & -- \\
\hline $1,443.8(4,737)$ & $\mathrm{SC}$ & $\mathrm{C}$ & -- & -- & -- & -- \\
\hline
\end{tabular}

a Depth represents base of 3-m (10-ft) sample interval for drill cuttings.

b Sample type: $\mathrm{DC}=$ drill cuttings; $\mathrm{SC}=$ sidewall core

C $\quad \mathbf{C}=$ analysis complete; -- = analysis not performed. Analysis type: PTS = polished thin section; MP = electron microprobe; $\mathbf{X R D}=x$-ray diffraction; $X R F=x$-ray fluorescence; $\mathrm{Fe}^{+2} / \mathrm{Fe}^{+3}=$ wet chemical analysis for iron. 
Table 3-4

Well ER-ER-5-3\#2 Geophysical Log Summary

(Page 1 of 2)

\begin{tabular}{|c|c|c|c|c|c|c|}
\hline Geophysical Log Type ${ }^{\text {a }}$ & Log Purpose & $\begin{array}{l}\text { Logging } \\
\text { Service }\end{array}$ & $\begin{array}{l}\text { Date } \\
\text { Logged }\end{array}$ & Run Number & $\begin{array}{c}\text { Bottom of Logged } \\
\text { Interval } \\
\text { meters (feet) }\end{array}$ & $\begin{array}{l}\text { Top of Logged } \\
\text { Interval } \\
\text { meters (feet) }\end{array}$ \\
\hline * Natural Gamma Ray Spectroscopy & $\begin{array}{l}\text { Stratigraphic correlation, } \\
\text { mineralogy, natural and man-made } \\
\text { radiation }\end{array}$ & Schlumberger & $05 / 11 / 2000$ & SGR-1 & $1,561.5(5,123)$ & $731.5(2,400)$ \\
\hline *Gamma Ray / Four Arm Caliper & $\begin{array}{l}\text { Borehole conditions, cement volume } \\
\text { calculation / } \\
\text { stratigraphic correlation }\end{array}$ & Schlumberger & $\begin{array}{l}05 / 05 / 2000 \\
05 / 06 / 2000 \\
05 / 09 / 2000 \\
05 / 10 / 2000 \\
05 / 11 / 2000\end{array}$ & $\begin{array}{l}\text { GR-1/CA4-1 } \\
\text { GR-2/CA4-2 } \\
\text { GR-4/CA4-3 } \\
\text { GR-5/CA4-4 } \\
\text { GR-8/CA4-5 }\end{array}$ & $\begin{array}{c}984.5(3,230) \\
1,207.0(3,960) \\
1,308.2(4,292) \\
1,614.2(5,296) \\
1,599.3(5,247)\end{array}$ & $\begin{array}{c}829.7(2,722) \\
829.7(2,722) \\
1,144.2(3,754) \\
829.7(2,722) \\
834.2(2,737)\end{array}$ \\
\hline $\begin{array}{l}\text { * Epithermal Neutron / Density / } \\
\text { Gamma Ray / Caliper }\end{array}$ & $\begin{array}{l}\text { Total water content / rock porosity / } \\
\text { stratigraphic correlation/ borehole } \\
\text { conditions }\end{array}$ & Schlumberger & $\begin{array}{l}05 / 06 / 2000 \\
05 / 10 / 2000\end{array}$ & $\begin{array}{l}\text { GR-3/ENP-1/CDL-1/ } \\
\text { CAL-1 } \\
\text { GR-6/ENP-2/ } \\
\text { CDL-2/CAL-2 }\end{array}$ & $\begin{array}{l}1,204.6(3,952) \\
1,614.2(5,296)\end{array}$ & $\begin{array}{l}714.5(2,344) \\
1,168.0(3,832)\end{array}$ \\
\hline $\begin{array}{l}\text { * Dual Laterolog / *Spontaneous } \\
\text { Potential / Gamma Ray }\end{array}$ & $\begin{array}{l}\text { Saturated zone: water saturation / } \\
\text { stratigraphic correlation }\end{array}$ & Schlumberger & $05 / 10 / 2000$ & DLL-1/SP-2/GR-7 & $1,601.4(5,254)$ & $714.5(2,344)$ \\
\hline $\begin{array}{l}\text { Gamma Ray / Digital Array Sonic } \\
\text { A. Wave-form and variable density } \\
\text { presentations } \\
{ }^{*} \text { B. Sonic porosity and travel time } \\
\text { (STC) computations }\end{array}$ & $\begin{array}{l}\text { Saturated zone: } \\
\text { A. Porosity, lithologic determination } \\
\text { B. Fracture identification }\end{array}$ & Schlumberger & 05/10/2000 & AC-1/ GR-7 & $1,596.5(5,238)$ & $714.5(2,344)$ \\
\hline Ultrasonic Borehole Imager & $\begin{array}{l}\text { Saturated zone: lithologic } \\
\text { characterization, fracture and void } \\
\text { analysis. }\end{array}$ & Schlumberger & $05 / 11 / 2000$ & BHTV-1 & $1,571.2(5,155)$ & $844.3(2,770)$ \\
\hline Temperature / Gamma Ray & $\begin{array}{l}\text { Saturated zone: groundwater } \\
\text { temperature / stratigraphic } \\
\text { correlation }\end{array}$ & Schlumberger & $\begin{array}{l}05 / 05 / 2000 \\
05 / 10 / 2000\end{array}$ & $\begin{array}{l}\text { TL-1/GR-1 } \\
\text { TL-2/SGR-2 }\end{array}$ & $\begin{array}{r}975.4(3,200) \\
1,584.4(5,198)\end{array}$ & $\begin{array}{l}710.2(2,330) \\
719.3(2,360)\end{array}$ \\
\hline $\begin{array}{l}\text { Percussion Sidewall Coring Tool / } \\
\text { Spontaneous Potential }\end{array}$ & $\begin{array}{l}\text { Geologic Samples / stratigraphic } \\
\text { correlation }\end{array}$ & Schlumberger & $05 / 06 / 2000$ & SGUN-1/SP-1 & $1,197.9(3,930)$ & $857.1(2,812)$ \\
\hline $\begin{array}{l}\text { Mechanical Sidewall Coring Tool / } \\
\text { Gamma Ray }\end{array}$ & $\begin{array}{l}\text { Geologic Samples / stratigraphic } \\
\text { correlation }\end{array}$ & Schlumberger & $05 / 13 / 2000$ & MCT-1/GR-9 & $1,443.8(4,737)$ & $1,191.8(3,910)$ \\
\hline Nuclear Annulus Investigation Log & Well construction monitoring & Colog & $\begin{array}{l}\text { 05/17- } \\
18 / 2000\end{array}$ & AIN-1 & $1,428.3(4,686)$ & $1,219.2(4,000)$ \\
\hline
\end{tabular}


Table 3-4

Well ER-5-3\#2 Geophysical Log Summary

(Page 2 of 2)

\begin{tabular}{|c|c|c|c|c|c|c|}
\hline Geophysical Log Type a & Log Purpose & $\begin{array}{l}\text { Logging } \\
\text { Service }\end{array}$ & $\begin{array}{l}\text { Date } \\
\text { Logged }\end{array}$ & Run Number & $\begin{array}{c}\text { Bottom of Logged } \\
\text { Interval } \\
\text { meters (feet) } \\
\end{array}$ & $\begin{array}{c}\text { Top of Logged } \\
\text { Interval } \\
\text { meters (feet) } \\
\end{array}$ \\
\hline Downhole Video & $\begin{array}{l}\text { Visual inspection of piezometer } \\
\text { string }\end{array}$ & $\begin{array}{l}\text { Desert } \\
\text { Research } \\
\text { Institute }\end{array}$ & $\begin{array}{c}04 / 05- \\
06 / 2000\end{array}$ & TV-1 & $282.5(927)$ & 0 \\
\hline $\begin{array}{l}\text { Formation Micro-Imager / Four-Arm } \\
\text { Caliper / Gamma Ray }\end{array}$ & $\begin{array}{l}\text { Lithologic characterization, fracture } \\
\text { and void analysis, stratigraphic } \\
\text { correlation }\end{array}$ & Schlumberger & $05 / 11 / 2000$ & FMI-1/CA4-5/GR-8 & $1,599.3(5,247)$ & $834.2(2,737)$ \\
\hline Color Television Camera & $\begin{array}{l}\text { Visual inspection of inside of } \\
\text { production casing }\end{array}$ & GeoVision & 02/15/01 & 1 & $365.8(1,200)$ & 0 \\
\hline Gyroscopic Directional Survey & Borehole Deviation & Gyrodata & 05/11/2001 & 1 & $1,490.5(4,890)$ & $7.6(25)$ \\
\hline
\end{tabular}

a Logs presented in geophysical log summary, Appendix D, are indicated by *.

b Depth below ground surface. 


\subsection{Hydrology of Well ER-5-3\#2}

\subsubsection{Preliminary Water Level Information}

Based on the pre-construction estimate of surface elevation at the site, depth to water was expected to be approximately $287.4 \mathrm{~m}$ (943 ft) (IT, 2000a). Fluid depths between 263.9 and $286.5 \mathrm{~m}$ (866 and $940 \mathrm{ft}$ ) were obtained from various geophysical logs run on May 10 and 11, 2000, before the completion string was installed. However, these levels are considered suspect because of the presence of high viscosity polymer in the fluid. A fluid level depth of $282.5 \mathrm{~m}$ (927.0 ft) was determined from a down-hole camera run by DRI on April 5, 2000, while the hole was at the depth of $622.7 \mathrm{~m}$ (2,043 ft), before the carbonate rocks were penetrated and before the surface casing was installed. This is considered to be the most reliable pre-development fluid level (IT, 2000b). Based on this preliminary fluid depth within the volcanic rocks and the as-built surface elevation of 1,016.3 $\mathrm{m}$ (3,334.3 ft), the fluid level

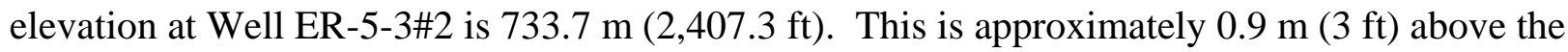
predicted elevation of $734.6 \mathrm{~m}(2,410 \mathrm{ft})$ A transducer for monitoring of the water level was not installed at the time of completion, but planned future hydrologic testing will provide more accurate water level data.

\subsubsection{Preliminary Water Production Information}

Water production was estimated during drilling of Well ER-5-3\#2 on the basis of LiBr dilution data as measured by IT field personnel (IT, 2000b). During drilling, water production was first noted at a depth of approximately $284.7 \mathrm{~m}$ (934 ft), on March 25, 2000. As expected, the welded tuff and dolomite units produced large volumes of water. Production increased steadily to about 1,741 lpm (460 gpm) at the depth of $622.7 \mathrm{~m}$ (2,043 ft) near the bottom of the alluvial section, before installation of the surface casing. As the underlying tuffs were penetrated, water production increased dramatically to more than 7,569 lpm (2,000 gpm) in the Rainier Mesa and Topopah Spring welded tuffs, in the depth interval 774.2 to $899.2 \mathrm{~m}$ (2,540 to 2,950 ft) (IT, 2000b). Installation of the intermediate casing blocked these high flow zones, but water production remained steady at about 3,027 to 4,541 lpm (800 to 1,200 gpm) until increasing again, starting at the depth of $1,510.6 \mathrm{~m}(4,956 \mathrm{ft})$ within the dolomite. A maximum flow rate of 8,893 lpm (2,350 gpm) was estimated at the depth of 1,732.3 $\mathrm{m}$ (5,683 ft), the well TD.

\subsubsection{Preliminary Thermal Flow Log Data}

No flow meter or chemistry log data were obtained from Well ER-5-3\#2 due to the presence of high-viscosity polymer in the fluid. 


\subsubsection{Preliminary Groundwater Characterization Samples}

No preliminary groundwater characterization samples were collected from Well ER-5-3\#2.

\subsection{Precompletion and Open-Hole Development}

No precompletion open-hole development was conducted in Well ER-5-3\#2 before installation of the completion string.

\subsection{Completion}

The planned installation of a piezometer string in the upper part of the well was prevented by borehole sloughing problems. The production casing was installed in Well ER-5-3\#2 on May 16, 2000, but the slotted portion of the casing became partly embedded in fill material, and was partly cemented. A recompletion effort was undertaken in March 2001, to try to gain access to the open casing below the cement plug and assure that well access to the lower carbonate aquifer (LCA) is isolated. This section describes the planned well design, the final as-built completion configuration, and the completion and recompletion operations. Figure 3-2 shows the final completion design for the well (after recompletion), Figure 3-3 shows a plan view and profile of the wellhead surface completion, and Table 3-5 is a construction summary for the well. Data for these sections were obtained from daily operations and activity reports, casing records, and cementing records provided by the BN Drilling Department. Information from IT's well data reports (IT, 2000b, 2001b) was also reviewed for preparation of this section.

\subsubsection{Proposed Completion Design}

The planned completion for Well ER-5-3\#2 was designed to provide isolated hydrologic access to the lower carbonate aquifer. A string of 51/2-in. stainless-steel casing (suspended from carbonsteel $75 / 8$-in. casing) with 1 slotted section would be installed to provide access to the carbonate rocks. In addition, a string of $27 / 8$-in. tubing would be installed as a piezometer outside the surface casing to provide access via a slotted section to the alluvial aquifer.

\subsubsection{As-Built Completion Design}

The design of the Well ER-5-3\#2 completion was determined through consultation with members of the UGTA TWG on the basis of onsite evaluation of data such as lithology, water production, drilling data (lost circulation, etc.), and data from geophysical logs (particularly caliper, borehole video, acoustic fracture log). The final as-built completion configuration of the well, as accomplished by both the original effort and recompletion activities, is described in this section. The composition of the completion string summarized here is detailed on Table 3-5, and the casing materials are listed in Appendix A-3. 


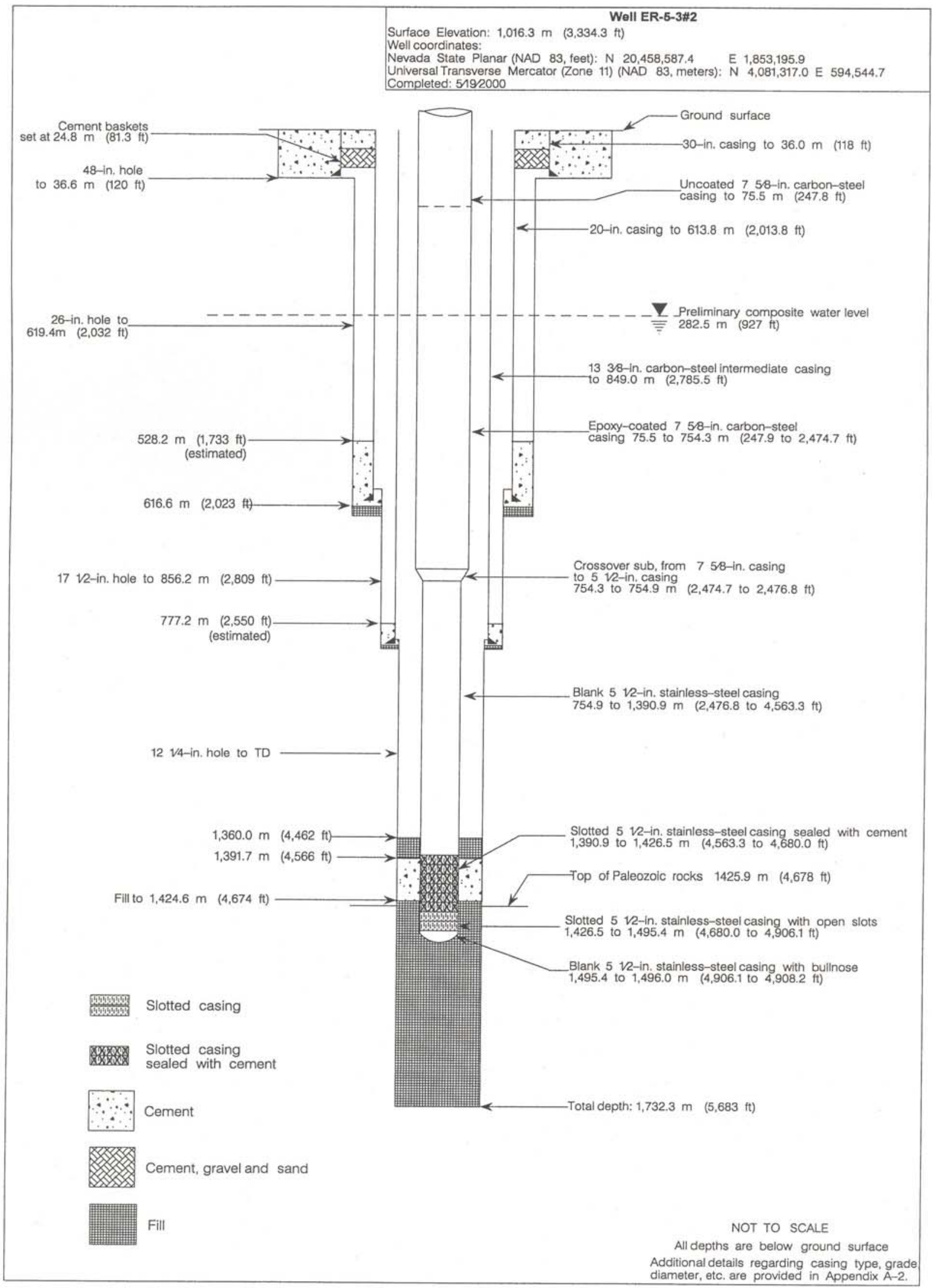

Figure 3-2

As-Built Completion Schematic for Well ER-5-3\#2 


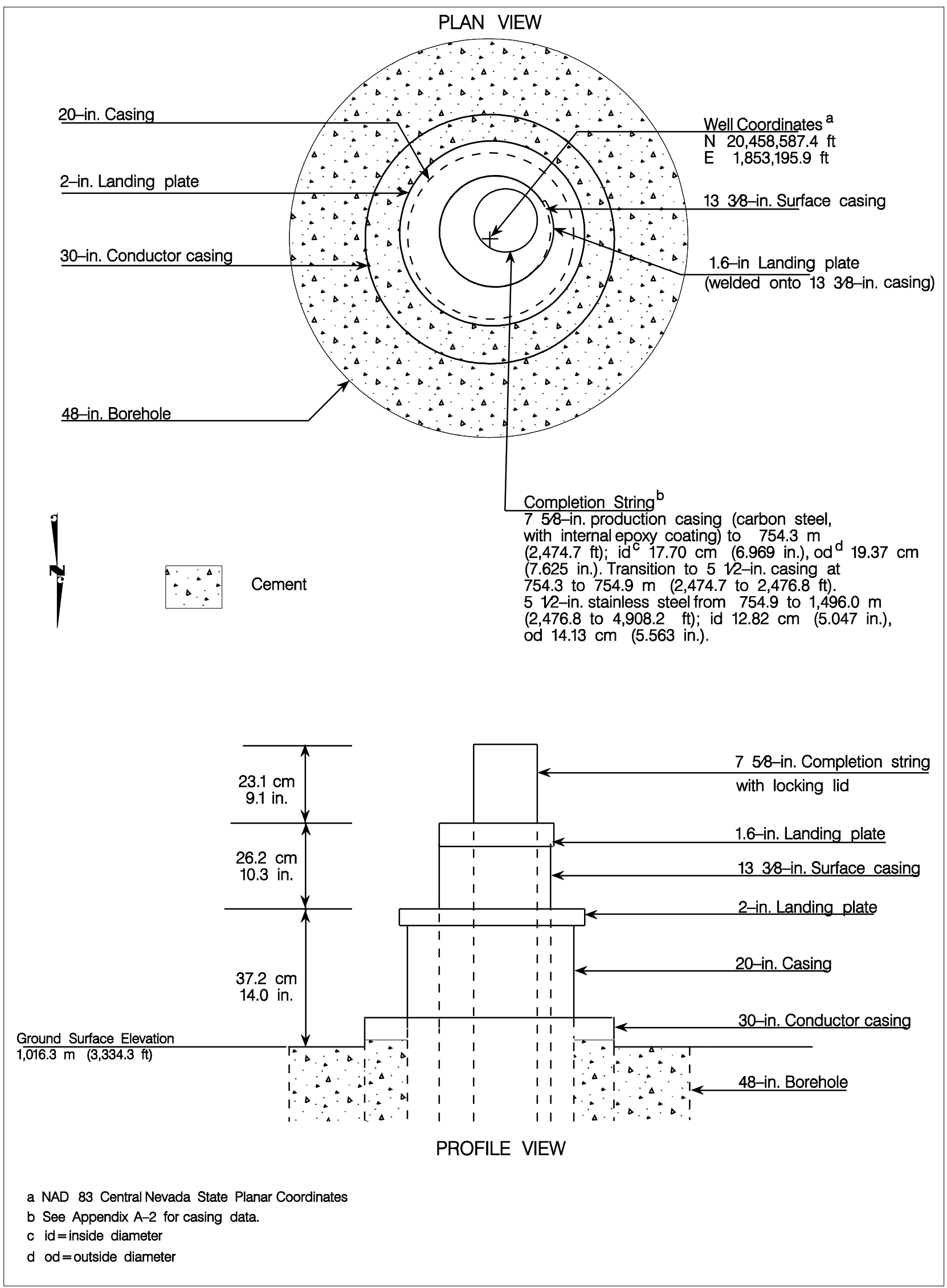

Figure 3-3

Wellhead Diagram for Well ER-5-3\#2 
Table 3-5

Well ER-5-3\#2 Completion String Construction Summary

\begin{tabular}{|c|c|c|c|c|}
\hline Casing Type & \multicolumn{2}{|c|}{$\begin{array}{l}\text { Configuration } \\
\text { meters (feet) }\end{array}$} & $\begin{array}{c}\text { Cement } \\
\text { meters (feet) } \\
\end{array}$ & $\begin{array}{l}\text { Sand/Gravel } \\
\text { meters (feet) } \\
\end{array}$ \\
\hline $\begin{array}{c}\text { 75/8-in. carbon-steel } \\
\text { production casing } \\
\text { with internal epoxy } \\
\text { coating }\end{array}$ & $\begin{array}{c}0 \text { to } 754.2 \\
\text { (0 to } 2,474.7 \text { ) }\end{array}$ & Blank & \multirow[b]{2}{*}{ None } & \multirow[b]{2}{*}{ None } \\
\hline $\begin{array}{l}\text { 75/8-in. to 51/2-in. } \\
\text { cross-over sub, } \\
\text { carbon steel with a } \\
\text { stainless-steel } \\
\text { double pin }\end{array}$ & $\begin{array}{c}754.2 \text { to } 754.9 \\
(2,474.4 \text { to } 2,476.8)\end{array}$ & Blank & & \\
\hline \multirow{3}{*}{$\begin{array}{l}\text { 51/2-in. stainless-steel } \\
\text { production casing }\end{array}$} & \multirow{3}{*}{$\begin{array}{c}754.9 \text { to } 1,496.0 \\
(2,476.8 \text { to } 4,908.2)\end{array}$} & $\begin{array}{c}\text { Blank } \\
754.9 \text { to } 1,390.8 \\
(2,476.8 \text { to } 4,563.3) \\
\end{array}$ & \multirow{3}{*}{$\begin{array}{c}\text { Type II } \\
1,391.7 \text { to } 1,424.6 \\
(4,566 \text { to } 4,674)\end{array}$} & \multirow{3}{*}{ None } \\
\hline & & $\begin{array}{c}\text { Slotted } \\
1,390.8 \text { to } 1,495.3 \\
(4,563.3 \text { to } 4,906.1)\end{array}$ & & \\
\hline & & $\begin{array}{c}\text { Slotted and } \\
\text { bull-nosed } \\
1,495.3 \text { to } 1,495.9 \\
(4,906.1 \text { to } 4,908.2)\end{array}$ & & \\
\hline
\end{tabular}

The lower section of the completion string (51/2-in. casing), from 754.9 to $1,496.0 \mathrm{~m}(2,476.8$ to 4,908.2 ft) is type SSTP304 stainless-steel casing with an outside diameter of $14.13 \mathrm{~cm}$ (5.563 in.) and an inside diameter of $12.82 \mathrm{~cm}$ (5.047 in.). The top of the 51/2-in. casing is approximately $472.4 \mathrm{~m}(1,550 \mathrm{ft})$ below the static fluid level. The bottom $0.6 \mathrm{~m}(2.1 \mathrm{ft})$ is blank and terminates in a bull-nose to serve as a sediment sump. A 0.6-m (2.1-ft) long cross-over sub is positioned at the top of the $5 \frac{1}{2} 2$-in. casing as the transition to the upper part of the string, which is $75 / 8$-in. carbon-steel casing with an internal epoxy coating.

The production casing has 1 slotted section, consisting of 8 joints. The openings in each slotted casing joint are $0.198 \mathrm{~cm}$ (0.078 in.) wide and $7.6 \mathrm{~cm}$ (3 in.) long, cut in rings of 18 slots (spaced 20 degrees apart around the joint). The rings are spaced $15.2 \mathrm{~cm}$ (6 in.) apart, and the longitudinal centers of the slots in each ring are staggered 10 degrees from the slot centers in the

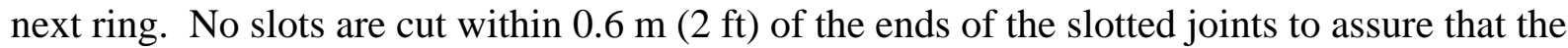
strength of the pipe near connections is not degraded. 
Due to problems caused by continued sloughing of the borehole wall, the slotted portion of the production casing could not be lowered to the desired depth within the carbonate rocks. The slotted interval spans the lower part of the Tertiary volcanic rocks and approximately the upper $69.5 \mathrm{~m}$ (228 ft) of the carbonate rocks. To isolate the lower part of the slotted string and leave the casing open only to the carbonate rocks, a cement plug was installed on top of additional fill that had risen to the depth of $1,424.6 \mathrm{~m}$ (4,674 ft). The top of the cement plug is at $1,391.7 \mathrm{~m}$ $(4,566 \mathrm{ft})$, near the top of the slotted section, and seals off the Tertiary rocks. During recompletion operations (see Section 3.6.4.2) this plug was re-cemented because it was determined that the upper slots were not completely sealed. Finally, a hole $11.1 \mathrm{~cm}$ (4.375 in.) in diameter was drilled through the resealed cement plug to gain access to the open part of the casing below the plug.

The planned piezometer string was not installed in Well ER-5-3\#2 due to borehole instability problems.

\subsubsection{Rationale for Difference Between Actual and Proposed Well Design} Conditions encountered within the lower portion of the Well ER-5-3\#2 borehole forced a more innovative design for this well. However, the objective of installing a completion zone isolated within the lower carbonate aquifer rocks was accomplished.

\subsubsection{Completion Method}

The final completion configuration of Well ER-5-3\#2 was reached in 2 phases, one immediately after drilling and logging were complete, and the other 10 months later, as a recompletion. These are described in the following paragraphs.

\subsubsection{Original Completion Installation}

Well-construction materials were inspected according to relevant procedures; standard decontamination procedures were employed to prevent the introduction of contaminants into the well.

After drilling and geophysical logging were completed, the drillers inserted a $2^{7} / 8$-in. tremie line before the casing crew inserted the production casing. The bottom of the casing hit fill at $1,498.1 \mathrm{~m} \mathrm{(4,915} \mathrm{ft})$, shallower than expected, so they pulled it up and landed it at 1,496.0 m $(4,908.2 \mathrm{ft})$. The tremie line through which stemming materials were planned to be emplaced was found to be plugged, so drillers removed and unplugged it, then reinserted it into the borehole. The NAIL tool, used to monitor completion progress, hit an obstruction inside 51/2-in. casing at 1,427.7 m (4,684 ft). A total of 6.4 cubic meters ( 225 cubic feet) of type II cement was 
pumped in 2 stages into the casing annulus from top of fill at 1,424.6 m (4,674 ft) to $1.391 .7 \mathrm{~m}$ $(4,566 \mathrm{ft})$. The tremie tubing again became plugged and was removed to clear it. When the tubing was being lowered back into the hole it tagged fill material at 1,360.0 m (4,462 ft). The crew rigged up to pump cement but the tremie tube was again found to be plugged, so the tubing was removed and completion operations were suspended. It was estimated that about $1.2 \mathrm{~m}$ (4 ft) of slotted tubing below the cement (within fill material) was in communication with Tertiary rocks (IT, 2000b).

\subsubsection{Recompletion}

Recompletion operations at Well ER-5-3\#2 were conducted in March 2001 to gain access to the open borehole below the $5 \frac{1}{2} 2$-in. production casing and insure that the LCA is isolated from other aquifers, as described in BN Field Activity Work Package Number D-003-001.01 (BN, 2001c).

A BN crew rigged up a truck-mounted Franks 300 work-over rig and circulated an air-foam drilling fluid to clean out the casing. Then they drilled an 11.1-cm (4.375-in.) diameter hole through the cement plug that had been emplaced across the slotted interval from $1,391.7 \mathrm{~m}$ $(4,566 \mathrm{ft})$ to the top of fill at 1,424.6 m (4,674 ft) during original completion operations. Water production while drilling through the cement plug during recompletion operations indicated that the slots within the cemented portion were not completely sealed. An additional 2.1 cubic meters (75 cubic feet) of type II neat cement were squeezed into the slots, using a retrievable cementing tool, to seal off that portion of the slotted interval and assure isolation of the LCA. After the squeeze job, the cement plug was re-drilled with a 43/4-in. bit. At a depth of approximately 1,426.5 $\mathrm{m}(4,680 \mathrm{ft})$ the bit drilled out of the bottom of the cement plug and into the open slotted interval of the completion casing. An obstruction was encountered at 1,483.7 m $(4,867.9 \mathrm{ft})$ and further drilling was terminated. Metal shavings in the drill cuttings suggest that the obstruction is either collapsed 51/2-in. production casing or the bull-nose termination of the $5 \frac{1}{2}$-in. production casing encountered at shallower than the expected depth of $1,495.4 \mathrm{~m}$ $(4,906.1 \mathrm{ft})$.

The quality of the cement squeeze job was tested by filling the casing string to the surface with water, and observing that the water level did not change over a 24-hour period.

\subsection{Actual Versus Planned Costs and Scheduling for Well ER-5-3\#2}

The original BN cost model developed for Well ER-5-3\#2 was based on drilling to the planned TD of 3,999.7 $\mathrm{m}(4,000 \mathrm{ft})$. The drilling program baseline projected that it would require 33 days to drill and complete the well. However, as with Well ER-5-3, the actual conditions encountered during drilling of the borehole (severe borehole instability, deeper than planned TD) 
were measurably different from predicted conditions, so the baseline was changed during drilling.

The new cost model is based on the actual TD of 1,732.2 m (5,683 ft). It took 58 days to accomplish drilling of the surface and main holes, logging, and completion of the well, after construction of the conductor hole by BN, and not including recompletion activities. A graphical comparison, by day, of planned and actual well-construction activities is presented in Figure 3-4.

The cost analysis for Well ER-5-3\#2 begins with the repositioning of the UDI drill rig on the Well Cluster ER-5-3 pad after drilling of Well ER-5-3. The cost of building roads, the drill pad, and sumps is not included, and the cost of well-site support by IT is not included. The total construction cost for Well ER-5-3\#2 includes all drilling costs: charges by the drilling subcontractor; charges by other support subcontractors (including compressor services, drilling fluids, bits, casing services, down-hole tools and, and geophysical logging); and charges by BN for mobilization and demobilization of equipment, partial construction of the conductor hole, cementing services, completion materials, radiation technicians, inspection services, and geotechnical consultation. Recompletion costs are not included.

The total planned cost for Well ER-5-3\#2, based on the new baseline, was $\$ 3,427,136$. The actual cost was $\$ 3,384,142$, or 1 percent less than the planned cost. Figure 3-5 presents a comparison of the planned (new baseline) and actual costs, by day, for drilling and completing Well ER-5-3\#2. 
DAYS

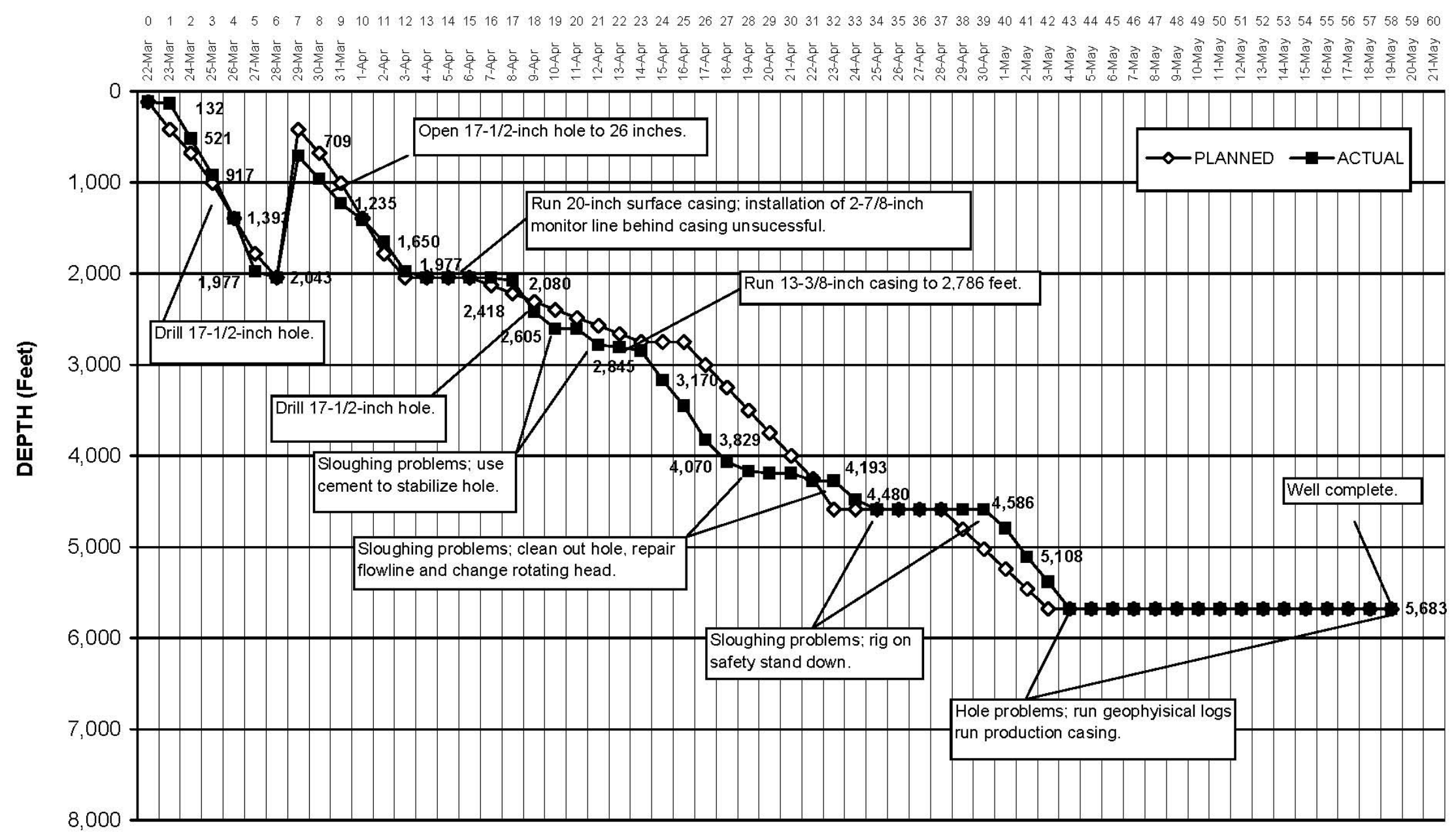

Figure 3-4

Planned versus Actual Construction Progress for Well ER-5-3\#2 


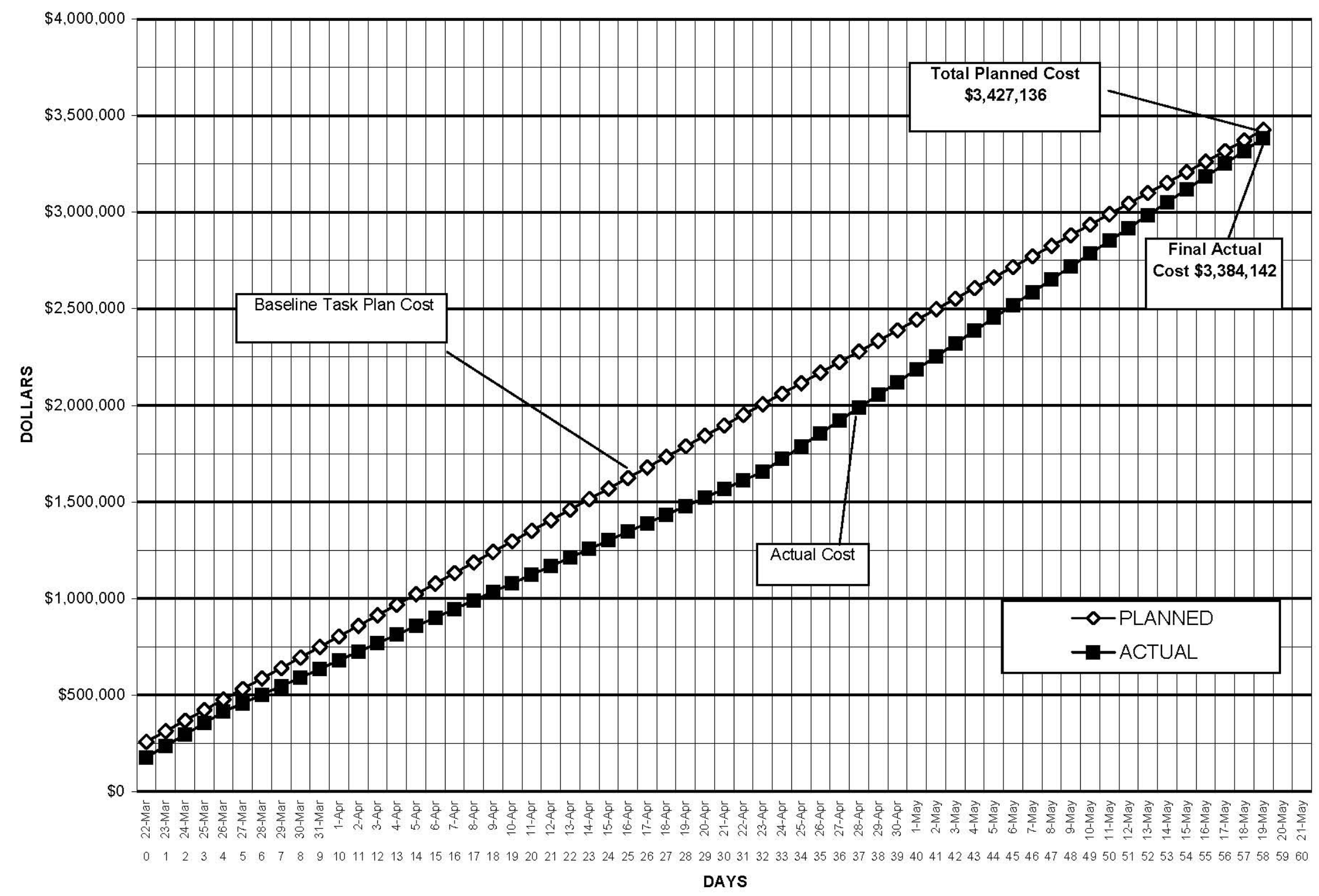

Figure 3-5

Planned versus Actual Cost for Constructing Well ER-5-3\#2 
This page intentionally left blank. 


\subsection{Well ER-5-3\#3}

\subsection{Well-Specific Objectives}

The scientific objectives listed in Section 1.2 of this report also apply to Well ER-5-3\#3, the third and last well drilled in the cluster. Interpretations based on hydrologic data and water samples from this well will be used to accomplish these objectives. The primary purpose of this well was to install a piezometer string for use as a water level monitoring point within the saturated alluvium. This will allow for long-term water level monitoring and measurement of draw-down during future long-term aquifer tests at this well cluster.

\subsection{Drilling Summary}

This section contains detailed descriptions of the drilling process and fluid management issues.

\subsubsection{Introduction}

The general drilling requirements for construction of Well ER-5-3\#3 are given in Frenchman Flat Hydrogeologic Investigation Wells Drilling and Completion Criteria, Revisions 0 and 1 (IT, 2000a, 2001a). Specific requirements for Well ER-5-3\#3 were outlined in Field Activity Work Plan Number D-001-003.01 (BN, 2001a). The following information was compiled primarily from BN daily drilling reports. Figure 4-1 is a chart of the drilling and completion history for Well ER-5-3\#3. A summary of drilling statistics for the well is given in Table 4-1. A hiatus of approximately 8 months took place between the drilling of Wells ER-5-3\#2 and ER-5-3\#3.

\subsubsection{Drilling History}

A BN crew used an auger rig to drill a 66.0-mm (26-in.) hole to the depth of $36.6 \mathrm{~m}$ (120 ft), January 12 to 17, 2001. The next day the BN crew set a string of 16-in. casing at the depth of $35.7 \mathrm{~m} \mathrm{(117} \mathrm{ft)} \mathrm{and} \mathrm{cemented} \mathrm{the} \mathrm{bottom} \mathrm{of} \mathrm{the} \mathrm{string} \mathrm{and} \mathrm{the} \mathrm{annulus} \mathrm{to} \mathrm{ground} \mathrm{level.} \mathrm{The} \mathrm{crew}$ drilled the rat and mouse holes, and anchor holes for the main rig on January 19 and 20, 2001.

The UDI crew mobilized to the site on January 26, 2001, and worked on setting up the Wilson Mogul 42B drill rig over the next 5 days (1 shift per day). On January 31, 2001, the drillers tagged the top of cement inside the conductor casing at the depth of $34.1 \mathrm{~m}(112 \mathrm{ft})$, and began drilling with a 97/8-in. bit. Drilling, with air-foam and a polymer additive as the fluid, progressed through the alluvium with no problems, and with little or no fill encountered on connections. An interval of basalt was encountered at the depth of $277.4 \mathrm{~m}$ (910 ft), just below the depth at which 


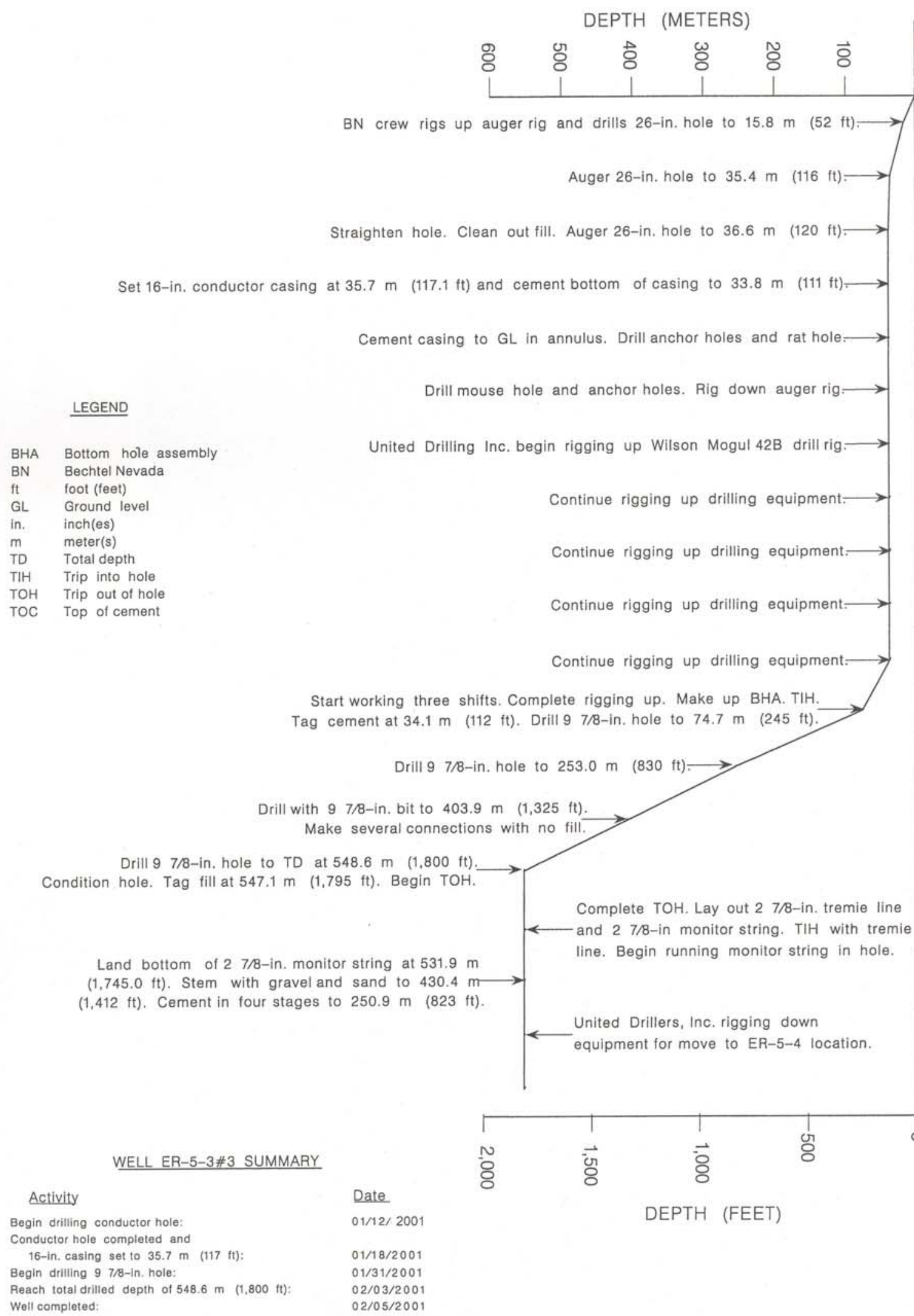

Land bottom of $27 / 8$-in. monitor string at $531.9 \mathrm{~m}$ $(1,745.0 \mathrm{ft})$. Stem with gravel and sand to $430.4 \mathrm{~m}$ $(1,412 \mathrm{ft})$. Cement in four stages to $250.9 \mathrm{~m}(823 \mathrm{ft})$.

WELL ER-5-3\#3 SUMMARY

Activity

Begin drilling conductor hole: Conductor hole completed and

16 -in. casing set to $35.7 \mathrm{~m}$ (117 ft):

Begin drilling $97 / 8$-in. hole:

Well completed:

Date

01/12/ 2001

$01 / 18 / 2001$

$01 / 31 / 2001$
$02 / 03 / 2001$

$02 / 05 / 2001$

Complete TOH. Lay out 2 7/8-in. tremie line and $27 / 8$-in monitor string. $\mathrm{TIH}$ with tremie

line. Begin running monitor string in hole.

United Drillers, Inc, rigging down equipment for move to ER-5-4 location.

Figure 4-1

Well ER-5-3\#3 Drilling and Completion History 
Table 4-1

Abridged Drill Hole Statistics for Well ER-5-3\#3

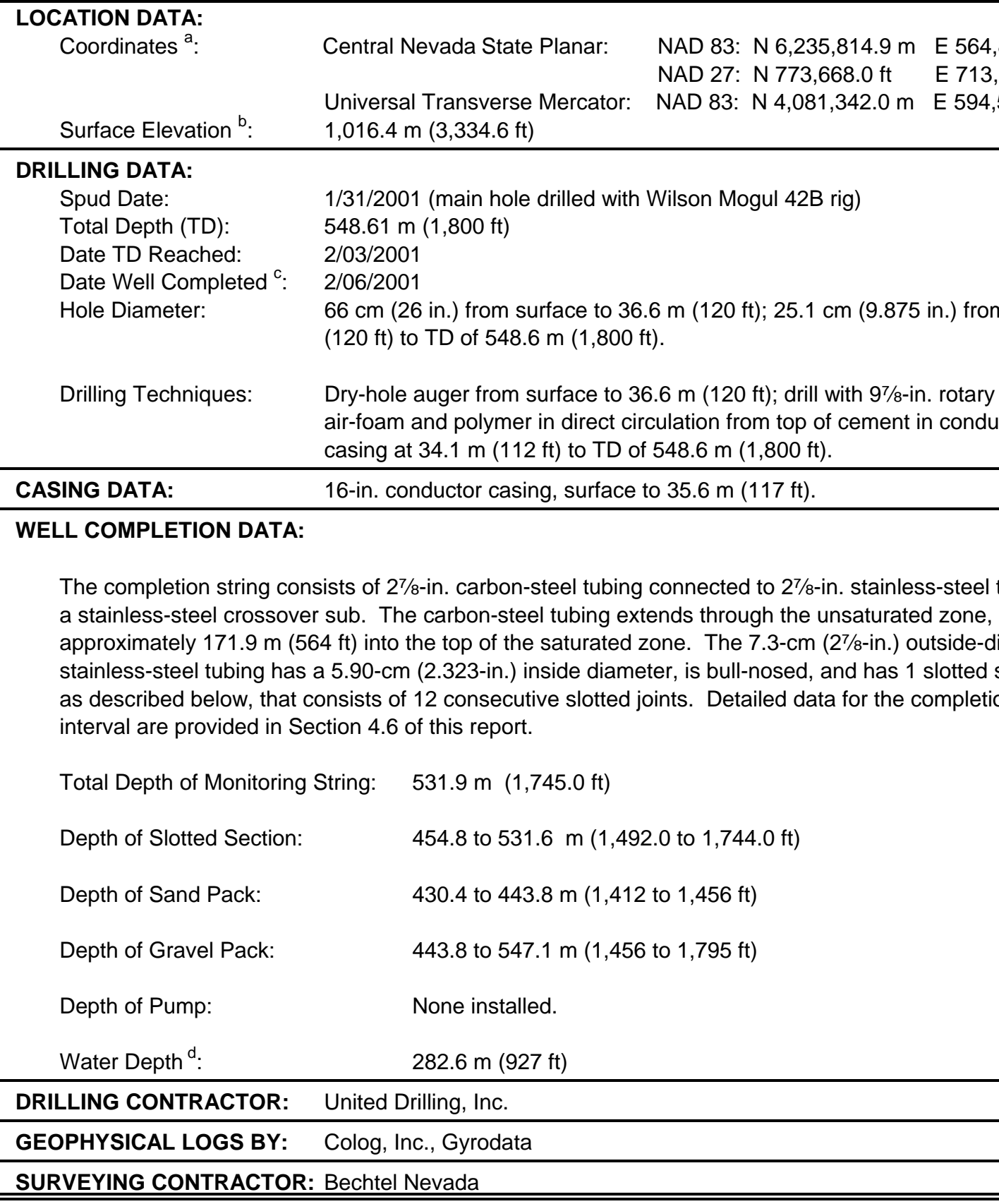
a stainless-steel crossover sub. The carbon-steel tubing extends through the unsaturated zone, interval are provided in Section 4.6 of this report.

Total Depth of Monitoring String: $\quad 531.9 \mathrm{~m}(1,745.0 \mathrm{ft})$

Depth of Slotted Section: $\quad 454.8$ to $531.6 \mathrm{~m}(1,492.0$ to $1,744.0 \mathrm{ft})$

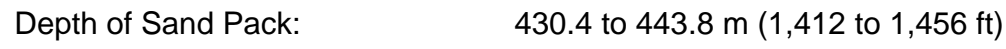

Depth of Gravel Pack: $\quad 443.8$ to $547.1 \mathrm{~m} \mathrm{(1,456}$ to $1,795 \mathrm{ft})$

Depth of Pump: None installed.

Water Depth ${ }^{\mathrm{d}}$ : $\quad 282.6 \mathrm{~m}(927 \mathrm{ft})$

DRILLING CONTRACTOR: United Drilling, Inc.

GEOPHYSICAL LOGS BY: Colog, Inc., Gyrodata

SURVEYING CONTRACTOR: Bechtel Nevada

The completion string consists of $2^{7 / 8}$-in. carbon-steel tubing connected to $2^{7 / 8}$-in. stainless-steel tubing via approximately $171.9 \mathrm{~m}(564 \mathrm{ft})$ into the top of the saturated zone. The $7.3-\mathrm{cm}\left(2^{7} / 8\right.$-in.) outside-diameter stainless-steel tubing has a $5.90-\mathrm{cm}$ (2.323-in.) inside diameter, is bull-nosed, and has 1 slotted section as described below, that consists of 12 consecutive slotted joints. Detailed data for the completion

a As-built coordinates measured by BN Survey.

b Elevation of ground level at collar. 1929 National Geodetic Vertical Datum.

c Date completion string was cemented.

d Measured by IT on February 21, 2001, approximately 2 weeks after completion string was installed. 
water production was first noted. Drilling continued with a 97/8-in. bit to the TD of $548.6 \mathrm{~m}$ $(1,800 \mathrm{ft})$, which was reached on February 3, 2001. The drillers conditioned the hole for a halfhour by circulating drilling fluid, then pulled the bit a short distance off bottom. When the drillers lowered the bit they encountered about $1.5 \mathrm{~m}(5 \mathrm{ft})$ of fill, then began removing pipe from the hole in preparation for installation of the completion string.

The directional survey run in Well ER-5-3\#3 on February 14, 2001 (after the well was completed) indicates that at the lowest surveyed depth of $528.2 \mathrm{~m}(1,733 \mathrm{ft})$ the hole had drifted $2.4 \mathrm{~m}(7.8 \mathrm{ft})$ to the south of the collar location, and that the hole is relatively straight (no "dog legs”).

A graphical depiction of drilling parameters including penetration rate, revolutions per minute, pump pressure, and weight on the bit is presented in Appendix A-1. See Appendix A-2 for a listing of casing materials. Drilling fluids and cements used in Well ER-5-3\#3 are listed in Appendix A-3.

\subsubsection{Drilling Problems}

No problems were encountered during drilling of Well ER-5-3\#3.

\subsubsection{Fluid Management}

Drilling effluent was monitored according to the methods prescribed in the UGTA FMP (DOE, 1999). The air-foam/polymer drill fluid was circulated down the inside of the drill string and back up the hole through the annulus (conventional or direct circulation) and then discharged into a sump. Water used to prepare drilling fluids came from Wells 5, 5b, and C-1. Lithium bromide was added to the drill fluid as a tracer to provide a means of estimating groundwater production based on dilution of $\mathrm{LiBr}$ in the return fluid.

As described in Section 2.3.3, 2 unlined sumps had been constructed to handle the expected high water production during construction of this well cluster (Figure 2-1). Modifications as described in Section 3.2.3 were made prior to drilling of Well ER-5-3\#2, but none were made prior to drilling of Well ER-5-3\#3. All fluids from Well ER-5-3\#3 were discharged to Sump \#2.

Samples of drilling effluent were tested onsite daily for the presence of tritium and lead.

Experience gained during drilling and sampling of Wells ER-5-3 and ER-5-3\#2 made this lower sampling frequency possible (Liebendorfer, 2001). The onsite monitoring results indicate that tritium remained at instrument background levels (ranging from 0 to $903.7 \mathrm{pCi} / \mathrm{L}$ ) and lead was undetectable (less than 50 parts per billion) during the entire drilling operation (IT, 2001b). 
Fluid samples were collected from Sump \#2 and from the sampling bucket (rinsate) after drilling was completed to demonstrate compliance with the FMP. The analytical results showed that the sump fluids were within the parameters of the FMP criteria (IT, 2001b). Water-quality data for both samples are given in Appendix B.

The results of analyses of samples of drilling fluid collected at Well ER-5-3\#3 during drilling operations indicate that all fluid quality objectives were met, as shown on the fluid management reporting form dated August 22, 2001 (Appendix B). The form lists volumes of solids (drill cuttings) and fluids produced during well-construction operations, Phase I, vadose- and saturated-zone drilling only (Phase II well development and aquifer testing were conducted at a later date and are not addressed in this report). The volume of solids produced was calculated using the diameter of the borehole (from caliper logs) and the depth drilled, and includes added volume attributed to a rock bulking factor. The volumes of fluids listed on the report are estimates of total fluid production, and do not account for any evaporation of fluids from the sump.

\subsection{Geologic Data Collection}

This section describes the sources of geologic data obtained from Well ER-5-3\#3 and the methods of data collection. Geologic data collected at Well ER-5-3\#3 consist only of drill cuttings. Adequate sidewall samples and geophysical logs were obtained from the alluvial section in the first two wells in this cluster, so no additional sidewall samples or logs were considered necessary from this section in Well ER-5-3\#3.

\subsubsection{Collection of Drill Cuttings}

Composite drill cuttings were collected from Well ER-5-3\#3 at 3-m (10-ft) intervals as drilling progressed from the depth of $36.6 \mathrm{~m}(120 \mathrm{ft})$ to the TD of the well at $548.6 \mathrm{~m}(1,800 \mathrm{ft})$. Triplicate 550-cc (1-pint) samples were collected from 168 intervals. These samples are stored under secure, environmentally controlled conditions at the USGS Geologic Data Center and Core Library in Mercury, Nevada. One of these sample sets was sealed with custody tape at the rig site and remains sealed as an archive sample; one set was left unsealed in the original sample containers; and the third set was washed and stored according to standard USGS Core Library procedures. The washed set was used by BN to construct the detailed lithologic log presented in Appendix C-3. The IT field representative collected two additional sets of reference samples from each of the cuttings intervals. One reference set was examined at the drill site for use in preparing field lithologic descriptions, and remains in the custody of SN-JV. The other set remains at LANL where it was sent for possible future petrographic, mineralogic, and chemical 
analyses. No laboratory analyses were done on samples from Well ER-5-3\#3 in support of this drilling project.

\subsubsection{Geophysical Logging Data}

The only geophysical logging conducted in Well ER-5-3\#3 was the borehole deviation log and the NAIL log used to monitor placement of the gravel, sand, and cement during completion operations (Table 4-2).

Table 4-2

Well ER-5-3\#3 Geophysical Log Summary

\begin{tabular}{|c|c|c|c|c|c|c|}
\hline $\begin{array}{c}\text { Geophysical Log } \\
\text { Type }\end{array}$ & Log Purpose & $\begin{array}{l}\text { Logging } \\
\text { Service }\end{array}$ & $\begin{array}{l}\text { Date } \\
\text { Logged }\end{array}$ & $\begin{array}{c}\text { Run } \\
\text { Number }\end{array}$ & $\begin{array}{c}\text { Bottom of } \\
\text { Logged } \\
\text { Interval }^{\mathrm{a}} \\
\text { meters (feet) }\end{array}$ & $\begin{array}{c}\text { Top of Logged } \\
\text { Interval a } \\
\text { meters (feet) }\end{array}$ \\
\hline $\begin{array}{l}\text { Nuclear Annulus } \\
\text { Investigation Log }\end{array}$ & $\begin{array}{l}\text { Well construction } \\
\text { monitoring }\end{array}$ & Colog & $02 / 05 / 2001$ & AIN-1 & $531.6(1,744)$ & $213.4(700)$ \\
\hline $\begin{array}{c}\text { Gyroscopic } \\
\text { Directional Survey }\end{array}$ & Borehole deviation & Gyrodata & $02 / 15 / 2001$ & 1 & $528.2(1,733)$ & 0 \\
\hline
\end{tabular}

a

Depth below ground surface

\subsection{Hydrology of Well ER-5-3\#3}

\subsubsection{Preliminary Water Level Information}

Based on the data from the first two wells in this cluster (see Sections 2.4 and 3.4) depth to water at Well ER-5-3\#3 was expected at approximately $282.5 \mathrm{~m}$ (927 ft). After the well was completed it was allowed to stabilize, and on February 21 2001, IT personnel measured the fluid depth of $282.7 \mathrm{~m}$ (927.6 ft) (IT, 2001b). Based on this fluid depth and the as-built surface elevation of 1,016.4 $\mathrm{m}$ (3,334.6 ft), the fluid level elevation at Well Cluster ER-5-3\#3 is $733.7 \mathrm{~m}$ $(2,407.0 \mathrm{ft})$, very close to the predicted elevation. A transducer for monitoring of the water level was not installed at the time of completion.

\subsubsection{Preliminary Water Production Information}

Water production was estimated during drilling of the wells in the ER-5-3 cluster on the basis of $\mathrm{LiBr}$ dilution data as measured by IT field personnel. Water production from Well ER-5-3\#3, at the rate of approximately $19 \mathrm{lpm}$ (5 gpm), was first noted during drilling at the depth of approximately $248.4 \mathrm{~m}$ (815 ft), on February 2, 2001. The flow rate had increased to a

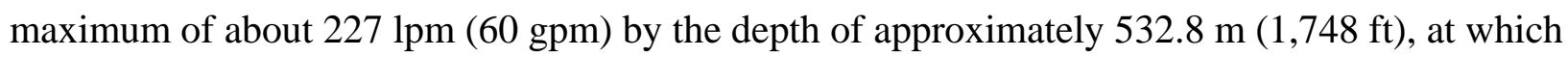
rate it remained steady to the TD of $548.6 \mathrm{~m}(1,800 \mathrm{ft})$. 


\subsubsection{Preliminary Thermal Flow Log Data}

Thermal flow, temperature, and chemistry logs were not run in Well ER-5-3\#3.

\subsubsection{Preliminary Groundwater Characterization Samples}

No preliminary groundwater characterization samples were collected from Well ER-5-3\#3, as adequate samples had already been obtained from the other two wells in the cluster.

\subsection{Precompletion and Open-Hole Development}

No precompletion open-hole development was conducted in Well ER-5-3\#3 before installation of the completion tubing.

\subsection{Completion}

The completion string was installed in Well ER-5-3\#3 on February 4, 2001. Figure 4-2 is a schematic diagram of the final well completion design for Well ER-5-3\#3, Figure 4-3 shows a plan view and profile of the wellhead surface completion, and Table 4-3 is a construction summary for the well. Data for this section were obtained from daily operations and activity reports, casing and tubing records, and cementing records provided by the BN Drilling Department. Information from IT's well data report (IT, 2001b) was also consulted for preparation of this section.

\subsubsection{Proposed Completion Design}

The planned completion for Well ER-5-3\#3 was designed to provide a water-level monitoring point in the saturated alluvium. The design called for string of 27/8-in. tubing, with a gravelpacked slotted interval at the bottom of the string, and the upper part sealed with cement. There was no plan to install a pump in this well.

\subsubsection{As-Built Completion Design}

The design of the Well ER-5-3\#3 completion was determined through consultation with members of the UGTA TWG. The final as-built completion configuration is described in this section. The composition of the piezometer string summarized here is detailed on Table 4-3, and the tubing materials are listed in Appendix A. 


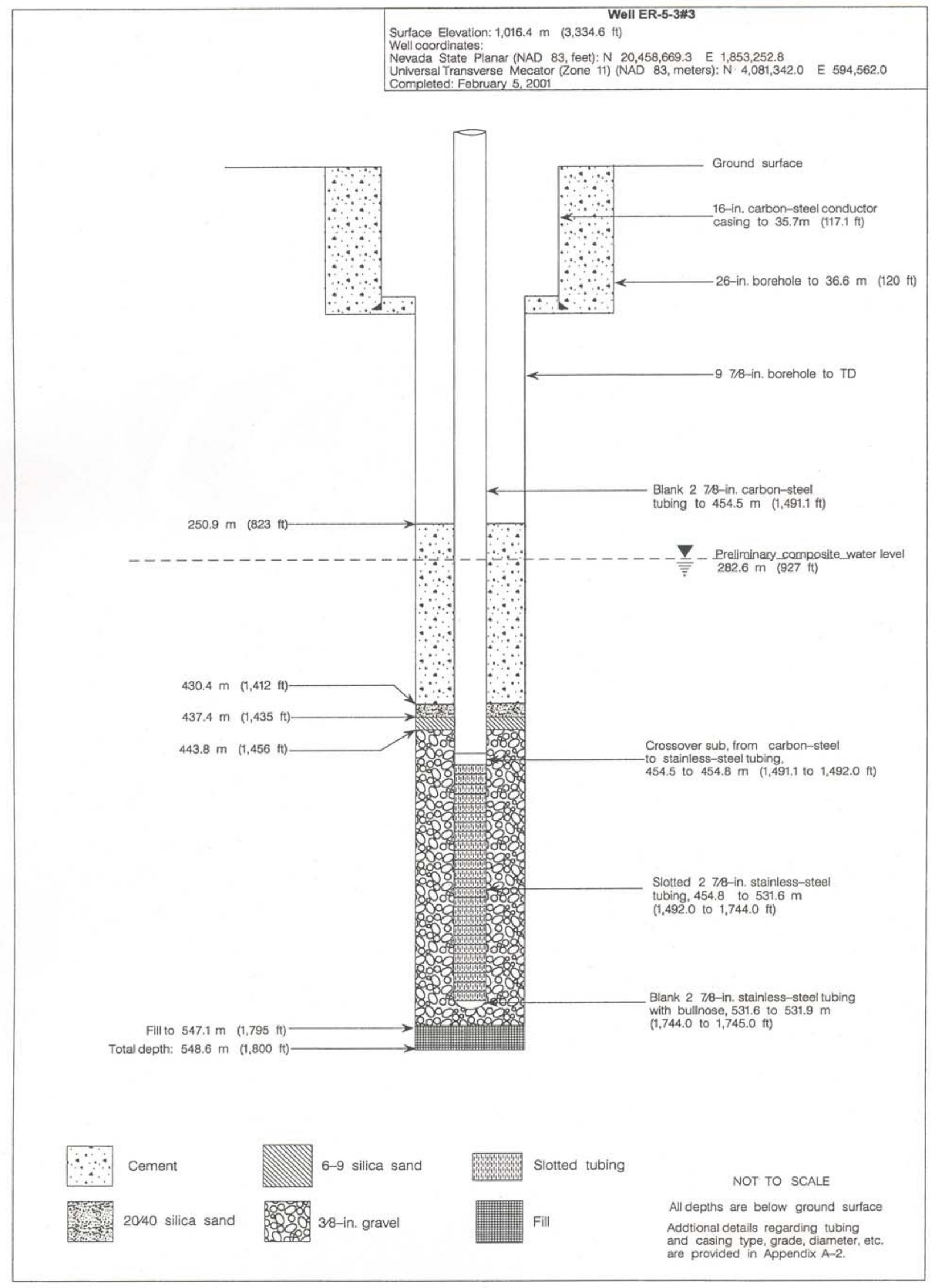

Figure 4-2

As-Built Completion Schematic for Well ER-5-3\#3 


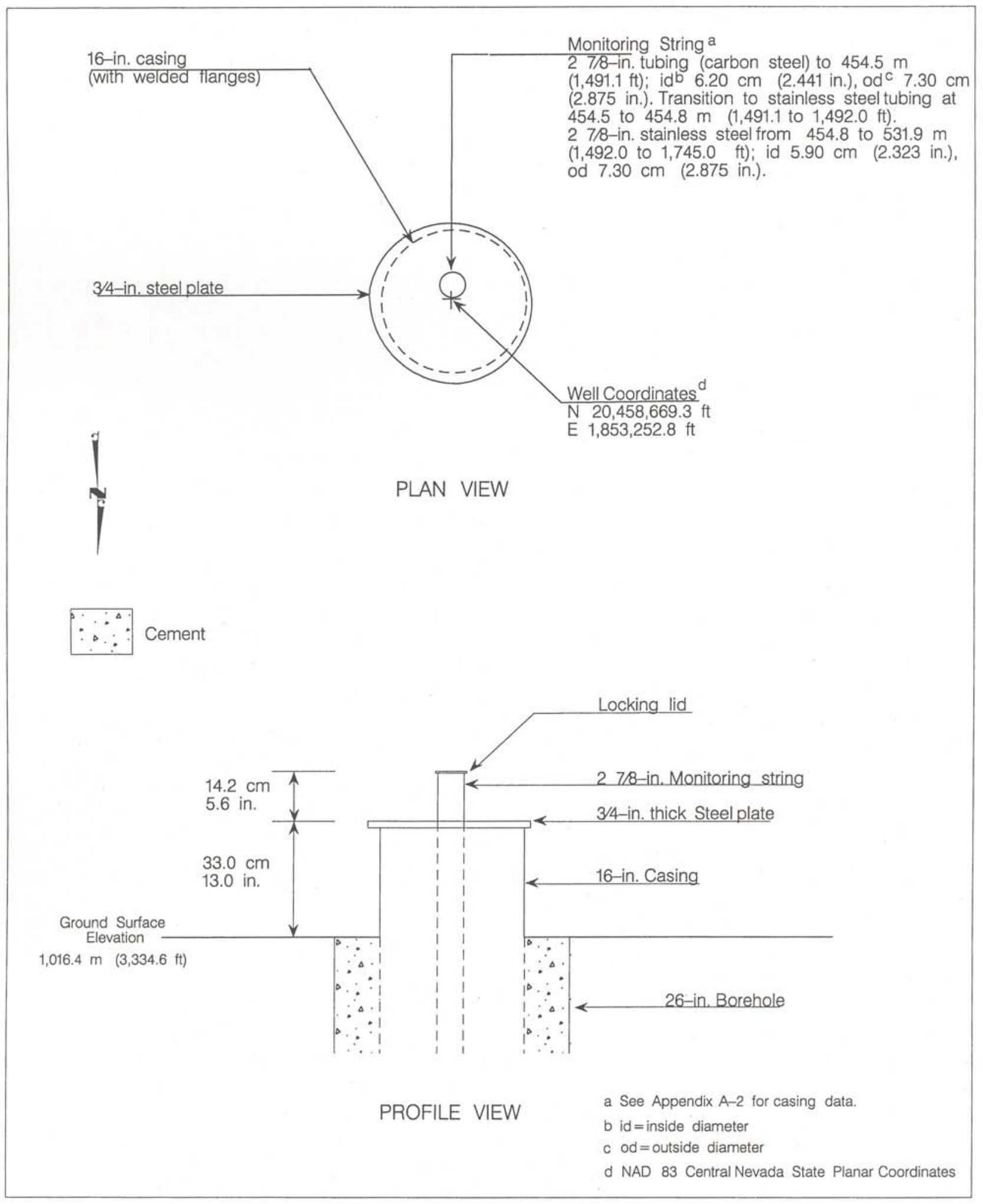

Figure 4-3

Wellhead Diagram for Well ER-5-3\#3 
Table 4-3

Well ER-5-3\#3 Completion String Construction Summary

\begin{tabular}{|c|c|c|c|c|}
\hline Casing Type & \multicolumn{2}{|c|}{$\begin{array}{l}\text { Configuration } \\
\text { meters (feet) }\end{array}$} & $\begin{array}{c}\text { Cement } \\
\text { meters (feet) }\end{array}$ & $\begin{array}{l}\text { Sand/Gravel } \\
\text { meters (feet) }\end{array}$ \\
\hline 27/8-in. carbon-steel tubing & $\begin{array}{c}0 \text { to } 454.5 \\
(0 \text { to } 1,491.1)\end{array}$ & Blank & \multirow{4}{*}{$\begin{array}{c}\text { Type II } \\
50.9 \text { to } 430.4 \\
823 \text { to } 1,412 \text { ) }\end{array}$} & \multirow{4}{*}{$\begin{array}{c}\frac{20 / 40 \text { Sand }}{430.4 \text { to } 437.4} \\
(1,412 \text { to } 1,435) \\
\\
\left.43 \frac{6-9 \text { Sand }}{(1,435 \text { to } 443.8} 1,456\right) \\
\text { 3/8-in. Gravel } \\
443.8 \text { to } 547.1 \\
(1,456 \text { to } 1,795)\end{array}$} \\
\hline $\begin{array}{l}2^{7 / 8-i n . ~ s t a i n l e s s-s t e e l ~} \\
\text { cross-over sub }\end{array}$ & $\begin{array}{c}454.5 \text { to } 454.8 \\
(1,491.1 \text { to } 1,492.0)\end{array}$ & Blank & & \\
\hline \multirow{2}{*}{$\begin{array}{l}2^{7 / 8} \text {-in. stainless-steel } \\
\text { tubing }\end{array}$} & $\begin{array}{c}454.8 \text { to } 531.6 \\
(1,492.0 \text { to } 1,744.0)\end{array}$ & Slotted & & \\
\hline & $\begin{array}{c}531.6 \text { to } 531.9 \\
(1,744.0 \text { to } 1,745.0)\end{array}$ & Blank and bull-nosed & & \\
\hline
\end{tabular}

The top of the monitoring string consists of carbon-steel, $27 / 8$-in. tubing with an inside diameter of $6.2 \mathrm{~cm}$ (2.441 in.) to the depth of $454.5 \mathrm{~m}(1,491.1 \mathrm{ft})$. A 0.3-m (0.9-ft) long cross-over sub is positioned at the bottom of the carbon-steel interval to serve as the transition to the slotted, stainless-steel tubing section, which extends from 454.8 to $531.6 \mathrm{~m}$ (1,492.0 to 1,744.0 ft). The stainless-steel tubing has an inside diameter of $5.9 \mathrm{~cm}$ (2.323 in). The bottom $0.3 \mathrm{~m}(1 \mathrm{ft})$ of the string is blank and bull-nosed to serve as a sediment sump.

The openings in the stainless-steel slotted tubing are $7.6 \mathrm{~cm}$ (3 in.) long, and $0.020 \mathrm{~cm}(0.08 \mathrm{in}$.) wide, placed on staggered 15.2-cm (6-in.) centers.

\subsubsection{Rationale for Difference Between Actual and Proposed Well Design}

The well was installed as proposed.

\subsubsection{Completion Method}

Well-construction materials were inspected according to relevant procedures; standard decontamination procedures were employed to prevent introduction of contaminants into the well. The filter pack around the slotted interval consists of $0.95-\mathrm{cm}(3 / 8-i n)$ by 4 -mesh washed pea gravel, with 6-9 Colorado silica sand directly above the gravel and 20/40 sand on top of the 6-9 sand. In this stemming design (as discussed in Section 2.6.4) the sand layers prevent fluids that might seep from the cement above from contaminating the groundwater. The installation of the piezometer string and stemming materials was completed on February 5, 2001. 
A $27 / 8$-in. tremie line was inserted into the borehole temporarily for emplacement of the gravel and sand. Then the $27 / 8$-in. monitoring line was run in the hole and landed at the depth of $531.9 \mathrm{~m}(1,745.0 \mathrm{ft})$, approximately $15.2 \mathrm{~m}$ (50 ft) above fill material left at the bottom of the hole. Approximately 7,906 kilograms (17,430 pounds) of gravel was dropped through the tremie line, filling the annulus around the piezometer to the depth of $443.8 \mathrm{~m}(1,456 \mathrm{ft})$. A layer of 6-9 sand was placed on top of the gravel up to the depth of $437.4 \mathrm{~m}(1,435 \mathrm{ft})$, followed by a layer of 20/40 sand to the depth of $430.4 \mathrm{~m}(1,412 \mathrm{ft})$. Neat type II cement was placed on top of the sand in 5 stages, to the depth of $250.9 \mathrm{~m}$ (823 ft), approximately $31.7 \mathrm{~m}$ (104 ft) above the static fluid level in the well. The borehole is open above $250.9 \mathrm{~m}(823 \mathrm{ft})$.

The drill rig was released after cementing was completed. Hydrologic testing at the well cluster was planned as a separate effort, so a pump was not installed in the well and no welldevelopment or pumping tests were conducted immediately after completion.

\subsection{Actual Versus Planned Costs and Scheduling for Well ER-5-3\#3}

The BN cost model developed for Well ER-5-3\#3 was based on drilling to the planned TD of $579.1 \mathrm{~m}(1,900 \mathrm{ft})$. The drilling program baseline projected that it would require 7 days to accomplish drilling of the surface and main holes, logging, and completion for the well, assuming the conductor hole would already have been constructed by BN. The actual time spent to drill the main and surface holes, and install the completion string in Well ER-5-3\#3 was 6 days. A graphical comparison, by day, of planned and actual well-construction activities is presented in Figure 4-4.

The cost analysis for Well ER-5-3\#3 begins with construction of the conductor hole by BN and the cost mobilizing the UDI drill rig to the Well ER-5-3\#3 site. The cost of building roads, the drill pad, and sumps is not included, and the cost of well-site support by IT is not included. The total construction cost for Well ER-5-3\#3 includes all drilling costs: charges by the drilling subcontractor; charges by other support subcontractors (including compressor services, drilling fluids, bits, casing services, down-hole tools and, and geophysical logging); and charges by BN for mobilization and demobilization of equipment, partial construction of the conductor hole, cementing services, completion materials, radiation technicians, inspection services, and geotechnical consultation.

The total planned cost for Well ER-5-3\#3 was $\$ 857,877$. The actual cost was $\$ 937,096$, or 8 percent more than the planned cost. Figure 4-5 is a comparison of the planned (baseline) and actual costs, by day, for drilling and completing Well ER-5-3\#3. 


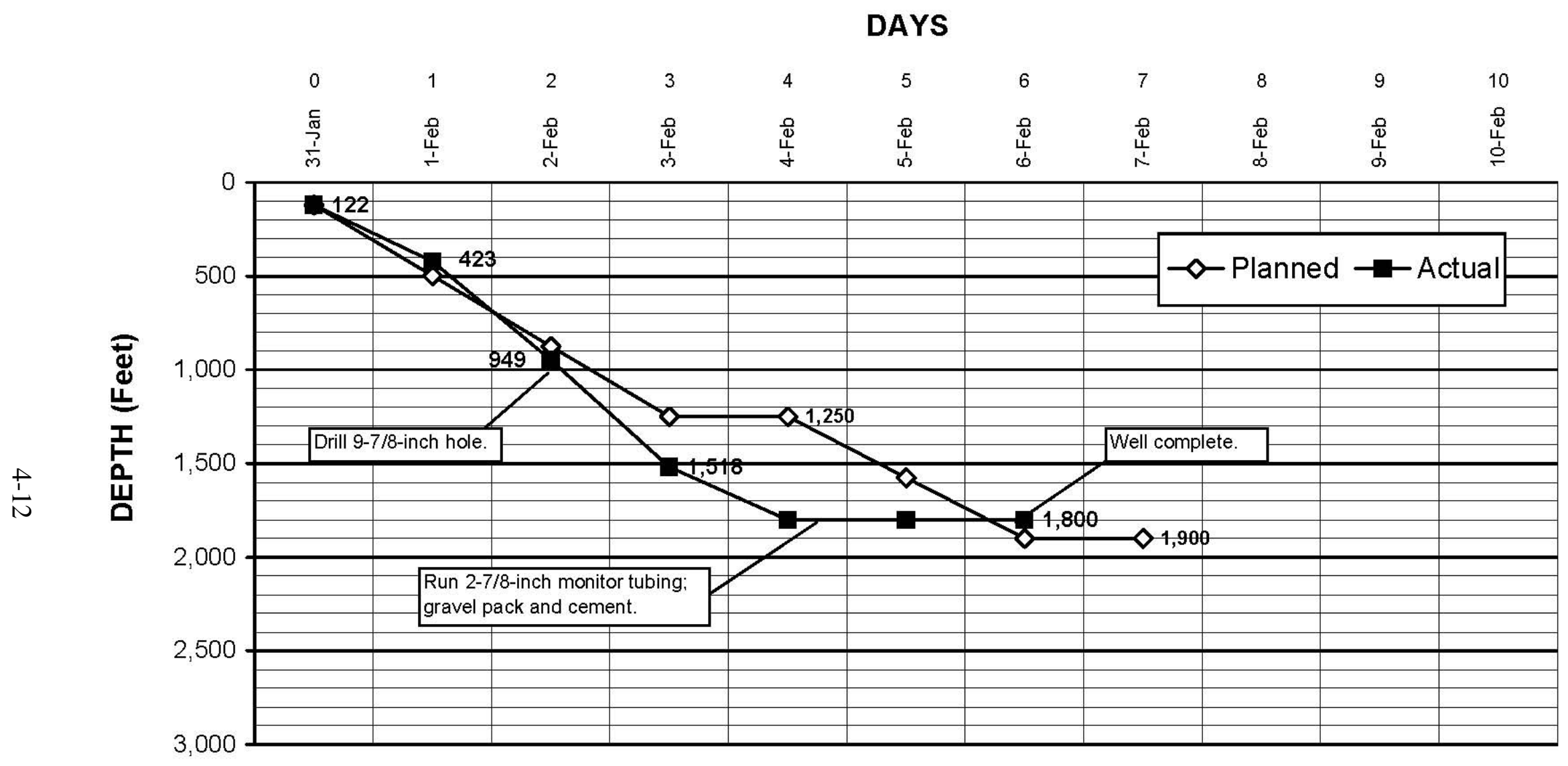

Figure 4-4

Planned versus Actual Construction Progress for Well ER-5-3\#3 


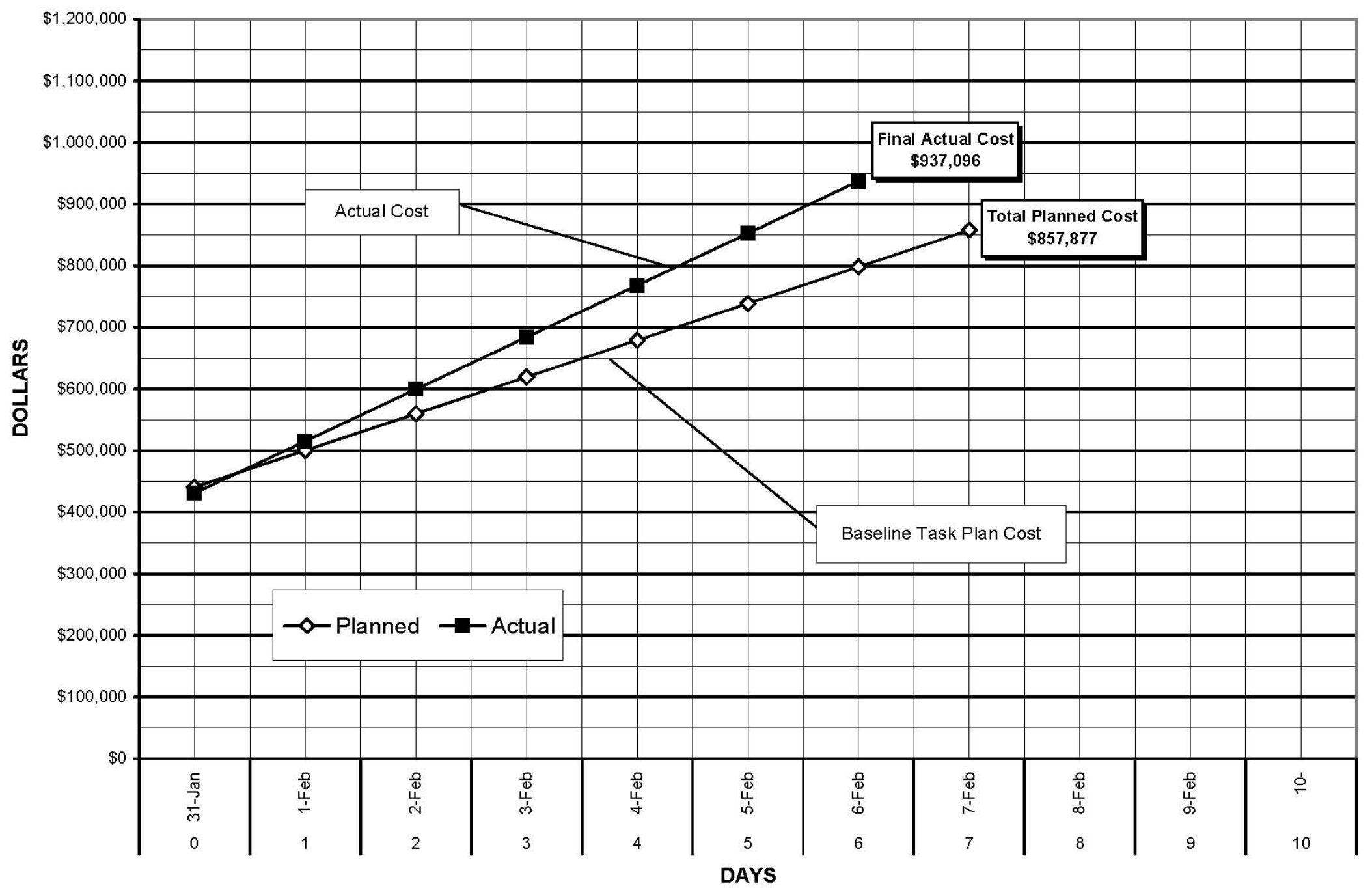

Figure 4-5

Planned versus Actual Cost for Constructing Well ER-5-3\#3 
This page intentionally left blank. 


\subsection{Geology and Hydrogeology of Well Cluster ER-5-3}

\subsection{Introduction}

This section describes the geology and hydrogeology of Well Cluster ER-5-3. The detailed lithologic logs for each well in the cluster are presented in Appendix C. The lithologic logs were developed using drill cuttings and sidewall core samples, geophysical logs, and drilling

parameters. Results from petrographic, mineralogic, and chemical analyses of selected lithologic samples were also incorporated into the lithologic logs. Regional (i.e., basin-wide) geologic interpretations and analyses provided in this section integrate the well information with surface geology and geophysical data including gravity (Phelps and Graham, 2002), aeromagnetic (Grauch and Hudson, 1995), and 3-D seismic reflection (Prothro, 2002).

\subsection{Geology}

This section is subdivided into three discussions that relate to the geology of the Well Cluster ER-5-3 site. Section 5.2.1 describes the geologic setting of Frenchman Flat and the well cluster. The stratigraphic and lithologic units penetrated at the well cluster are discussed in Section 5.2.2. Because of the significant influence some alteration products have on the hydraulic properties of certain rocks, alteration of the rocks encountered at the well cluster is discussed separately in Section 5.2.3. More detailed descriptions of the stratigraphy, lithology, and alteration of the rocks encountered are provided in Appendix C.

\subsubsection{Geologic Setting}

Well Cluster ER-5-3 lies on a south-sloping surface of alluvium (Figure 5-1) in the northern portion of Frenchman Flat (see Figure 1-1). Frenchman Flat is a hydrologically closed, Cenozoic-age basin formed in response to basin-and-range extension. Topographically, the basin is roughly oval-shaped, elongated in a northeast direction, and contains the Frenchman Lake playa which marks the topographic low point of the basin.

Rocks exposed in the highlands around the margins of Frenchman Flat consist of Tertiary-age volcanic and tuffaceous sedimentary rocks that overlie complexly folded and faulted Paleozoicage sedimentary rocks (Hinrichs and McKay, 1965; Poole, 1965; Poole et al., 1965; Hinrichs, 1968; McKeown et al., 1976; Barnes et al., 1982). Volcanic rocks exposed around Frenchman Flat are mostly Miocene-age tuffs of generally rhyolitic composition erupted from large calderas located 40 kilometers (km) (25 miles [mi]) northwest of Frenchman Flat, and intermediate- 
This page intentionally left blank. 


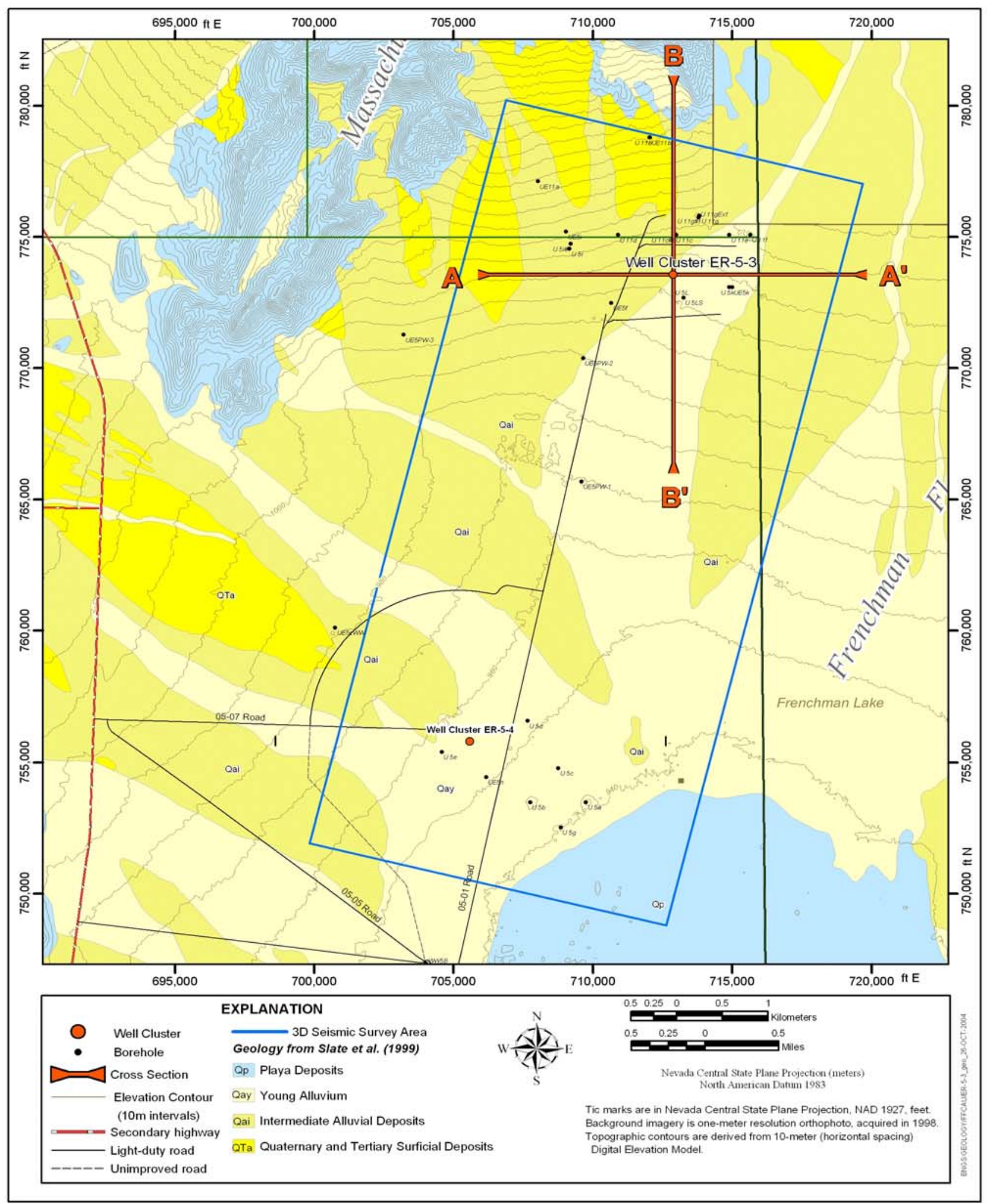

Figure 5-1

Surface Geologic Map of the Well ER-5-3 Site 
This page intentionally left blank. 
composition tuffs, lavas, and debris flows from the Wahmonie volcanic center located adjacent to Frenchman Flat on the west. Tuffaceous sedimentary rocks appear to occur within a rather narrow, linear, northeast-trending depositional area that generally corresponds to the topographic axis of the basin (Prothro and Drellack, 1997). These rocks are exposed along the southern margin of the basin where they consist of a diverse assemblage of fluvial and lacustrine sandstone and mud-rocks, freshwater limestone, conglomerate, and volcanic tuff. The tuffaceous sedimentary rocks appear to be partly coeval with the older volcanic rocks and thus likely interfinger with the volcanic rocks beneath Frenchman Flat. Paleozoic-age sedimentary rocks are exposed along the south and east sides of Frenchman Flat and consist mostly of carbonate rocks ranging in age from Cambrian to Mississippian. Drilling and geophysical data from Frenchman Flat indicate that many of the rocks exposed along the margins of the basin are present beneath Frenchman Flat and have been buried by thick aprons of alluvial debris shed from the exposed highlands during basin development. Alluvial deposits obtain a thickness of 1,676.4 $\mathrm{m}(5,500 \mathrm{ft})$ in the central portion of Frenchman Flat based on interpretation of seismic data (Prothro, 2002).

Modeling of surface gravity data shows the basin to be a northeast-trending, roughly oval, bowlshaped depression (Grauch and Hudson, 1995; Phelps and Graham, 2002). Using the gravity inversion method, Phelps and Graham (2002) estimated the maximum depth to Paleozoic rocks beneath the Frenchman Flat basin at 2,400 m (8,000 ft). Recently acquired 3-D seismic reflection data from a 36.3-square-kilometer (14-square-mile) area of northern and central Frenchman Flat indicate a maximum depth of about 3,017.5 m (9,900 ft) within the seismic survey area corresponding to the central portion of the basin (Great Basin Exploration Consultants [GBEC], 2002). The depth to the top of the Paleozoic rocks in northern Frenchman Flat ranges from $1,066.8$ to $1,767.8 \mathrm{~m}$ (3,500 to 5,800 ft) based on the seismic data (Prothro, 2002).

Although the gravity data do not indicate any major horst-and-graben structures beneath the basin, analysis of aeromagnetic data from Frenchman Flat reveals magnetic boundaries in the subsurface that are interpreted to represent buried faults (Grauch and Hudson, 1995). Integrating the geophysical data with regional structural analyses, Grauch and Hudson (1995) developed a conceptual structural model for Frenchman Flat. This model indicates that in a broad sense, Frenchman Flat is probably best described structurally as an east-tilted half-graben with a major basin-forming fault(s) along its eastern margin. The main faults beneath the basin are likely north-trending, down-to-the-west normal faults that merge southward into the east-northeast striking Rock Valley strike-slip fault system. 
The highlands that bound Frenchman Flat on the north are part of the French Peak structural accommodation zone (Hudson, 1992). This accommodation zone separates east-tilted extensional fault blocks in the Frenchman Flat area from west-tilted extensional fault blocks in Yucca Flat to the north.

In summary, geological and geophysical data suggest that Frenchman Flat is an oval, bowlshaped depression elongated in a northeast direction. The basin is best characterized as a large east-tilted half-graben bounded along its eastern margin by a west-dipping normal fault(s) that likely merges into the Rock Valley strike-slip fault system beneath the southern portion of the basin. On the north the basin is bounded by the French Peak structural accommodation zone which separates Frenchman Flat from Yucca Flat. In its deepest portions, Frenchman Flat basin probably contains from 2,400 to 3,017.5 m (8,000 to 9,900 ft) of mostly Tertiary-age alluvium, volcanic rocks, and tuffaceous sedimentary rocks, that overlie complexly deformed Paleozoicage sedimentary rocks.

\subsubsection{Stratigraphy and Lithology}

The stratigraphic and lithologic units penetrated at Well Cluster ER-5-3 are illustrated in Figure 5-2. Well ER-5-3 reached TD at $794.3 \mathrm{~m}$ (2,606 ft) in moderately welded ash-flow tuff of the Rainier Mesa Tuff. Well ER-5-3\#2 is the deepest hole in the cluster, reaching TD within Paleozoic dolomite at 1,732.2 m (5,683 ft). Well ER-5-3\#3, the shallowest of the 3 holes, reached TD at $548.6 \mathrm{~m}(1,800 \mathrm{ft})$ within alluvium.

Due to the close proximity of the wells to each other, the geology encountered is very similar for all 3 holes within common intervals penetrated. Thus, the units encountered above $548.6 \mathrm{~m}$ $(1,800 \mathrm{ft})$ are very similar in all 3 wells. Likewise, the units encountered in the interval 548.6 to $794.3 \mathrm{~m}$ (1,800 to 2,606 ft) are very similar in Wells ER-5-3 and ER-5-3\#2. The geology encountered by the 3 wells is described herein collectively for the well cluster. The geology described from surface to $792.5 \mathrm{~m}(2,600 \mathrm{ft})$ is from Well ER-5-3 because a more complete data set is available from this well for this interval. The descriptions of rocks below the depth of $792.5 \mathrm{~m}$ (2,600 ft) are from Well ER-5-3\#2. Detailed lithologic logs for each of the 3 holes are provided in Appendix C. The relative position, extent, and thickness of the stratigraphic units near Well Cluster ER-5-3 are illustrated on the cross sections in Figures 5-3 and 5-4. 


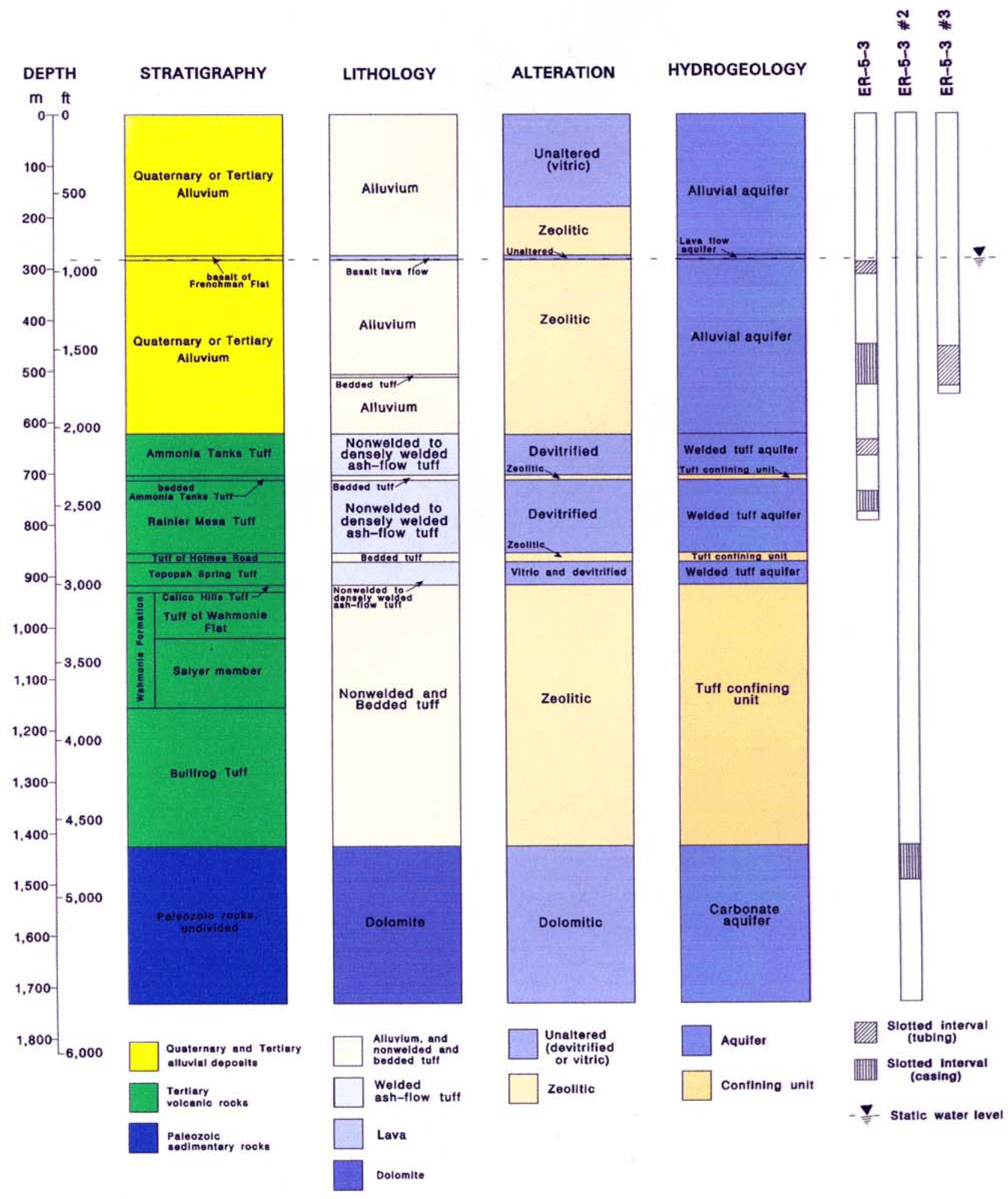

Figure 5-2

Geology and Hydrogeology of Well Cluster ER-5-3 Showing Locations of Slotted Intervals 
This page intentionally left blank. 


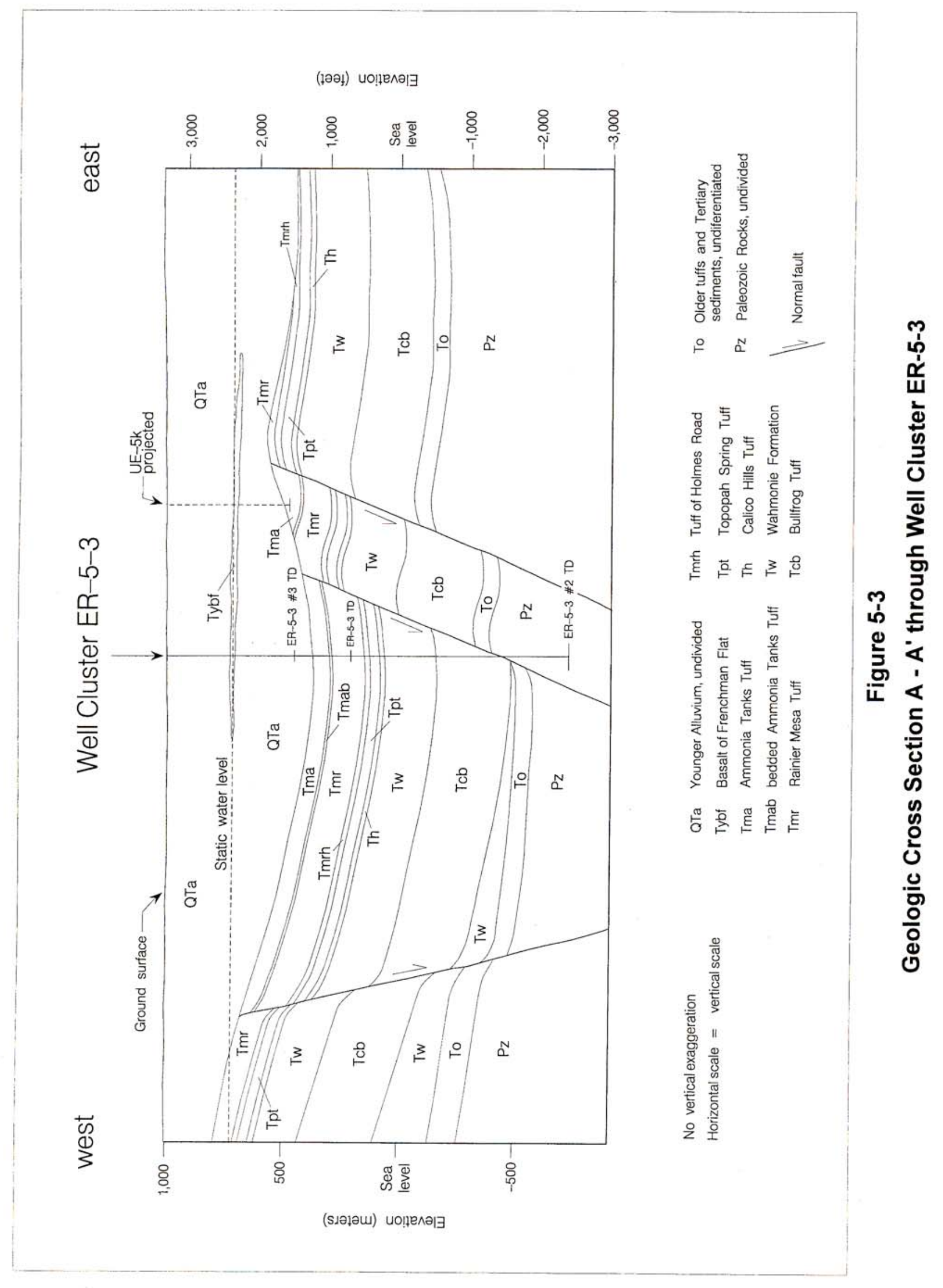




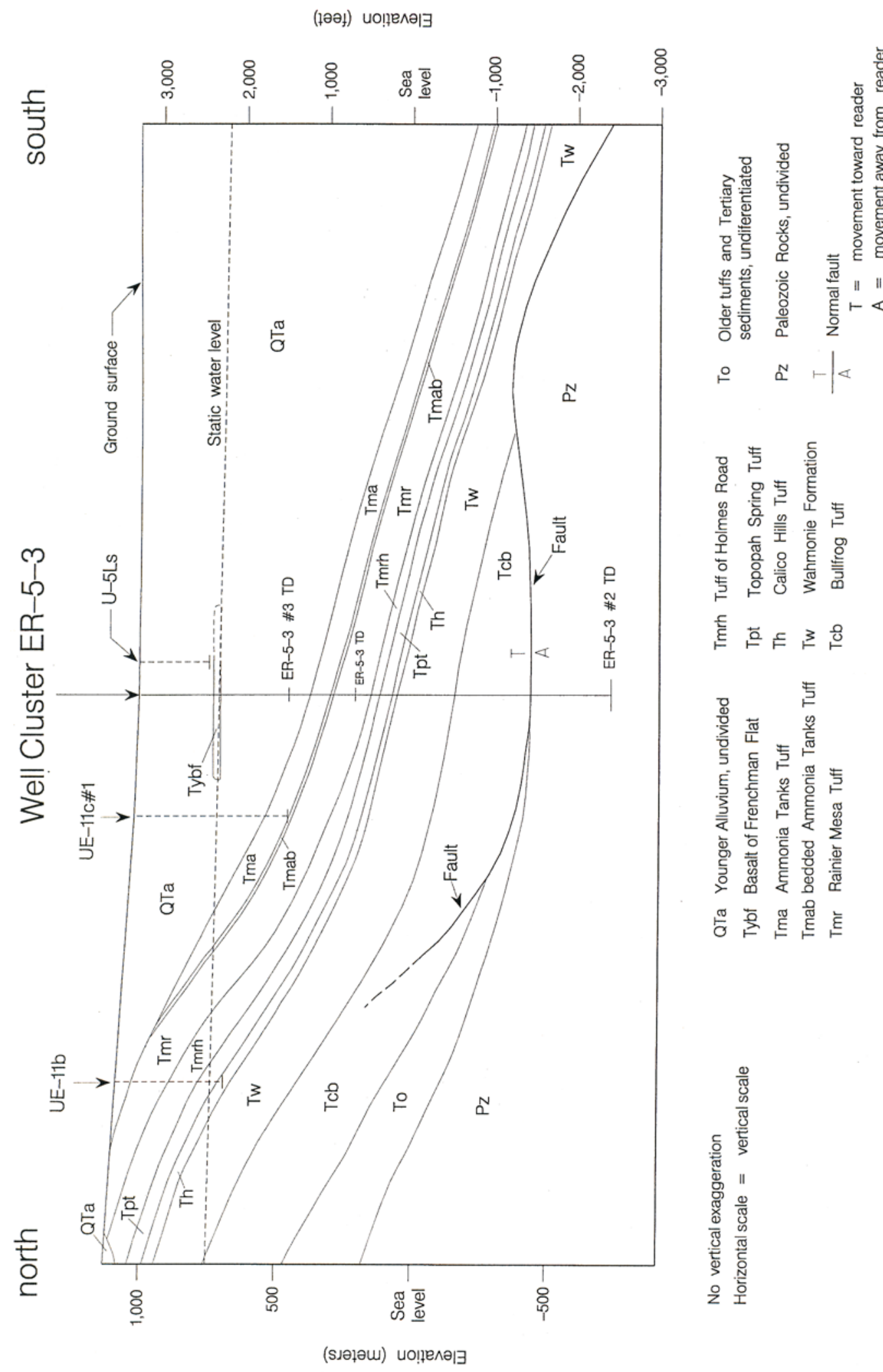

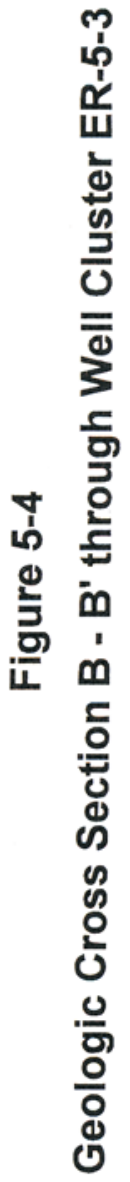


Tertiary- and Quaternary(?)-age alluvium was penetrated from the surface to the depth of $622.4 \mathrm{~m}(2,042 \mathrm{ft})$. The alluvium consists mostly of poorly to moderately sorted gravel and sand associated with alluvial fan deposition. Finer-grained intervals of clayey sand and clay occur

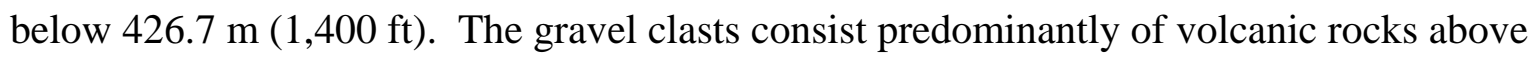
approximately $274.3 \mathrm{~m}$ (900 ft). These clasts are mostly welded ash-flow tuff from the Ammonia Tanks, Rainier Mesa and Topopah Springs Tuffs (Warren, 2000) and are most likely derived from the French Peak/Massachusetts Mountain area located north and west of the well cluster location, where those units are extensively exposed. Below approximately $274.3 \mathrm{~m}$ $(900 \mathrm{ft})$, the gravel clasts are predominantly Paleozoic sedimentary rocks, particularly quartzite. These clasts are derived from highlands east and northeast of Frenchman Flat where Paleozoic sedimentary rocks, including the Eureka Quartzite, and Cretaceous(?) or early Tertiary conglomerate composed chiefly of Cambrian quartzite pebbles and cobbles are exposed (Tschanz and Pampeyan, 1970). Near the bottom of the alluvial section at Well Cluster ER-5-3, gravel clasts consisting of volcanic rocks increase in abundance. The increase in abundance of these clasts at the base of the alluvial section probably represents erosion of the volcanic cover from the rising highland to the east and northeast. Petrographic and mineralogic analyses of sidewall core samples indicate that the matrix of the alluvium is tuffaceous, and that above $179.8 \mathrm{~m}$ (590 ft) the alluvial matrix has not been significantly altered since deposition (Warren,

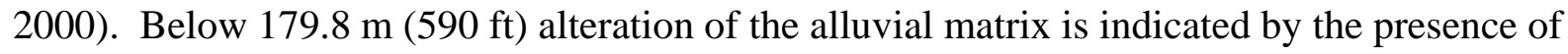
zeolitic minerals replacing the original vitric constituents (see additional discussion of alteration in Section 5.2.3).

A 8.5-m (28-ft) thick layer of basalt assigned to basalt of Frenchman Flat (Warren, 2000), based on petrographic character, was penetrated from 275.2 to $283.8 \mathrm{~m}$ (903 to $931 \mathrm{ft}$ ) within the alluvium. Basalt of Frenchman Flat is approximately 8.5 million years old (Ma) (Warren et al., 2002) and was also encountered at nearby holes UE5i and UE5k (Dixon et al., 1967; Byers and Miller, 1966).

A 5.2-m (17-ft) thick interval of bedded tuff consisting mostly of ash-fall and lesser reworked tuff is present within the alluvial section from 507.5 to $512.7 \mathrm{~m}$ (1,665 to 1,682 ft). The stratigraphic assignment of the tuff has not been determined, but its age is constrained between 8.5 Ma, the age of basalt of Frenchman Flat, and 11.45 Ma, the age of Ammonia Tanks Tuff (Sawyer et al., 1994) which is the first volcanic unit encountered below the alluvium at this site.

Tuffaceous volcanic rocks of Tertiary age were encountered at the depth of $622.4 \mathrm{~m}(2,042 \mathrm{ft})$. The first volcanic unit encountered is the Ammonia Tanks Tuff consisting of $80.5 \mathrm{~m}(264 \mathrm{ft})$ of 
devitrified partially to densely welded ash-flow tuff. Both the mafic-rich and mafic-poor members of the formation were encountered. The stratigraphic assignment is based on the abundance of felsic phenocrysts of both feldspar and quartz, moderate amounts of mafic minerals of biotite and clinopyroxene, and especially the presence of sphene and adularescent sanidine, both of which are highly diagnostic of the Ammonia Tanks Tuff. The Ammonia Tanks Tuff was erupted 11.45 Ma (Sawyer et. al., 1994) from the Timber Mountain caldera complex located approximately $40 \mathrm{~km}(25 \mathrm{mi})$ northwest of Frenchman Flat.

Below the Ammonia Tanks Tuff Well ER-5-3 penetrated $8.5 \mathrm{~m}$ ( $28 \mathrm{ft}$ ) of zeolitic bedded tuff, consisting mostly of reworked tuff, with lesser ash-fall tuff near the base of the interval. The rocks in this interval are assigned to the bedded Ammonia Tanks Tuff based on their lithologic character and stratigraphic position between the ash-flow tuffs of the Ammonia Tanks Tuff and Rainier Mesa Tuff.

The Rainier Mesa Tuff was encountered directly beneath the bedded Ammonia Tanks Tuff at a depth of $711.4 \mathrm{~m}$ (2,334 ft). The Rainier Mesa Tuff consists of $144.2 \mathrm{~m}$ (473 ft) of zeolitic and devitrified, nonwelded to densely welded ash-flow tuff. Both the mafic-rich and mafic-poor members of the formation were encountered. The stratigraphic assignment of Rainier Mesa Tuff to the rocks penetrated from 711.4 to $855.6 \mathrm{~m} \mathrm{(2,334} \mathrm{to} \mathrm{2,807} \mathrm{ft)} \mathrm{is} \mathrm{based} \mathrm{on} \mathrm{the} \mathrm{ash-flow} \mathrm{tuff}$ lithology, stratigraphic position below the Ammonia Tanks Tuff, and the primary mineralogy, which consists of moderate amounts of quartz, feldspar, and biotite, only rare volcanic lithic fragments, and the absence of sphene. The Rainier Mesa Tuff was erupted 11.6 Ma (Sawyer et al., 1994) from the Timber Mountain caldera complex.

Below the Rainier Mesa Tuff, $16.8 \mathrm{~m}$ (55 ft) of zeolitic bedded tuff assigned to the Tuff of Holmes Road was penetrated. The stratigraphic assignment is based mainly on lithologic character, the presence of quartz, and abundance and variety of mafic minerals.

Another ash-flow tuff was encountered below the Tuff of Holmes Road in the interval 872.3 to $921.7 \mathrm{~m}$ (2,862 to 3,024 ft). This ash-flow unit is assigned to the Topopah Spring Tuff based mainly on its stratigraphic position and ash-flow tuff lithology, especially the presence of a vitrophyre at the top of the unit which is characteristic of the Topopah Spring Tuff in this area. The observation of moderate amounts of felsic phenocrysts including very rare quartz, and mafic minerals that include biotite and clinopyroxene are also characteristic of the Topopah Spring Tuff. At Well Cluster ER-5-3 the Topopah Spring Tuff consists of devitrified and silicic nonwelded to densely welded and vitrophyric ash-flow tuff. The Topopah Spring Tuff was 
erupted 12.8 Ma (Sawyer et al., 1994) from a caldera probably located in the vicinity of the southern portion of the Timber Mountain caldera complex approximately $48 \mathrm{~km}$ (30 mi) west of Frenchman Flat.

A relatively thin $(9.5 \mathrm{~m}$ [31 ft]) interval of zeolitic bedded tuff was penetrated below the Topopah Spring ash-flow tuff. This minor bedded tuff unit is tentatively identified as Calico Hills Formation based mainly on its stratigraphic position. However petrographic analyses suggest that portions of this interval may include units within the upper portion of the Crater Flat Group (Warren, 2000).

The borehole then penetrated $225.8 \mathrm{~m}$ (741 ft) of mostly of zeolitic nonwelded tuff, from 931.2 to $1,157.0 \mathrm{~m}$ (3,055 to 3,796 ft). This interval is assigned to the 13.0-Ma Wahmonie Formation mainly on the basis of its mafic-rich character, including the presence of orthopyroxene, and the very rare occurrence of quartz. Petrographic analysis confirms the assignment by the total absence of sanidine and the presence of apatite, both highly diagnostic of the Wahmonie Formation (Warren, 2000). Rocks of the Wahmonie Formation were erupted 13.0 Ma from the Wahmonie volcano (Sawyer et. al., 1994), the remnants of which form the highlands that border Frenchman Flat on the west.

Below the Wahmonie Formation, $268.8 \mathrm{~m}$ (882 ft) of ash-flow tuff and bedded tuff were penetrated from 1,157.0 to 1,425.9 m (3,796 to 4,678 ft). The interval is assigned to the Bullfrog Tuff based on the petrographic character of drill cuttings samples from the interval (Warren, 2000). The upper $24.4 \mathrm{~m}$ (80 ft) of the Bullfrog Tuff interval at the well cluster consists of zeolitic bedded tuff overlying $44.5 \mathrm{~m}$ (146 ft) of nonwelded to partially welded, zeolitic and devitrified ash-flow tuff. The lower $199.9 \mathrm{~m}$ (656 ft) of the interval consists of zeolitic and quartzo-feldspathic bedded and nonwelded tuff. The Bullfrog Tuff was erupted 13.25 Ma (Sawyer et. al., 1994) from the Silent Canyon caldera complex located approximately $56 \mathrm{~km}$ (35 mi) northwest of Frenchman Flat.

Paleozoic-age dolomite was encountered directly below the Bullfrog Tuff at the depth of 1,425.9 m (4,678 ft) in Well ER-5-3\#2. Geologic data from the well suggest that the contact between the Bullfrog Tuff and dolomite is a fault. Older volcanic units are typically present below the Bullfrog Tuff in Yucca Flat to the north. Field reconnaissance by Prothro and Drellack (1997) in the vicinity of Nye Canyon approximately $8 \mathrm{~km}$ (5 mi) northeast of the well cluster also showed that volcanic units older than the Bullfrog are present in the area. This may indicate that these older volcanic units have been faulted out in Well ER-5-3\#2, and that the 
Tertiary volcanic section is thinner than might be expected at the well cluster, due to the presence of a fault. In addition, the dolomite penetrated from 1,425.9 to 1,493.5 m (4,678 to 4,900 ft) exhibits an unusual light pinkish color and is conspicuously crystalline, characteristics more typical of recrystallized dolomite, which may indicate proximity to a fault. Below $1,493.5 \mathrm{~m}(4,900 \mathrm{ft})$ the dolomite is medium gray to grayish black and finely crystalline, characteristics more typical of dolomite units in the region. The drill hole data are also consistent with interpretations of 3-D seismic data in the area (Prothro, 2002; GBEC, 2002) that show a west-dipping normal fault cutting Well ER-5-3\#2 very near the 1,425.9-m (4,678-ft) depth (Figure 5-5).

\subsubsection{Alteration}

In general, the degree of alteration of units penetrated at the well cluster increases systematically downward (Warren, 2000), as summarized here and illustrated in Figure 5-2. The alluvium from the surface to $179.8 \mathrm{~m}$ (590 ft) is generally unaltered, as indicated by the vitric character of the matrix. Below $179.8 \mathrm{~m}$ (590 ft) the alluvium has undergone low-grade zeolitic alteration resulting in the original vitric constituents in the matrix having been altered to the zeolite clinoptilolite. Except for vitrophyric intervals, the welded ash-flow tuffs encountered from 622.4 to $914.4 \mathrm{~m}$ (2,042 to 3,000 ft) are mostly devitrified. The original vitric constituents within the nonwelded and bedded tuffs of the volcanic section have been altered mainly to zeolite. Above approximately 1,005.8 m (3,300 ft) clinoptilolite is the dominant alteration mineral within these tuff units. From 1,005.8 to 1,219.2 m (3,300 to 4,000 ft), the zeolites mordenite and analcime occur with clinoptilolite indicating an increase in the degree of alteration. Below 1,219.2 $\mathrm{m}(4,000 \mathrm{ft})$, analcime is the dominant zeolite within the volcanic units, indicating a moderate level of quartzo-feldspathic alteration. Silicification appears to be common from 1,258.8 to $1,425.9 \mathrm{~m}(4,130$ to $4,678 \mathrm{ft})$, as indicated by the abundance of silicified fragments in the cuttings. As discussed previously, the dolomite from 1,425.9 to 1,493.5 m (4,678 to 4,900 ft) appears to have been recrystallized along and adjacent to a fault that cuts the Well ER-5-3\#2 borehole at 1,425.9 m (4,678 ft).

\subsection{Predicted Versus Actual Geology}

The actual geology encountered at the well cluster differs in two main ways from that predicted prior to drilling (IT, 2000a): the volcanic rocks are thicker and the Paleozoic rocks are deeper (Figure 5-6). The volcanic rocks are $356.3 \mathrm{~m}$ (1,169 ft) thicker than predicted, and the top of the Paleozoic rock section occurs $328.6 \mathrm{~m}(1,078 \mathrm{ft})$ deeper than predicted. This is in spite of strong evidence that the contact between the Tertiary volcanic and Paleozoic carbonate rocks is a westdipping normal fault that has resulted in a portion of the volcanic section being faulted out and 


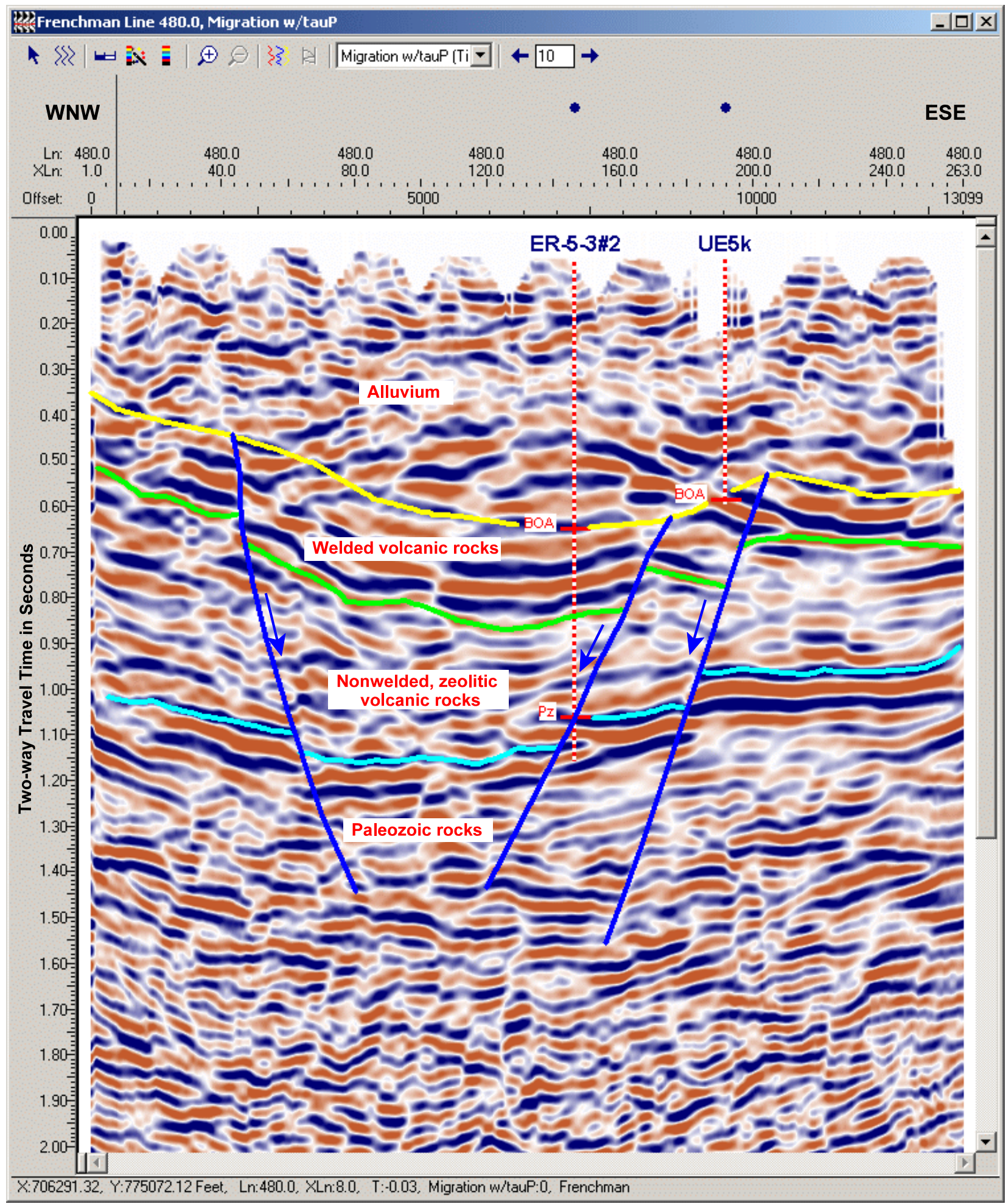

Figure 5-5

West-northwest to East-southeast Seismic Profile Through Well ER-5-3\#2

(BOA = base of the alluvium, $\mathrm{Pz}=$ top of Paleozoic rocks) 
This page intentionally left blank.

5-16 


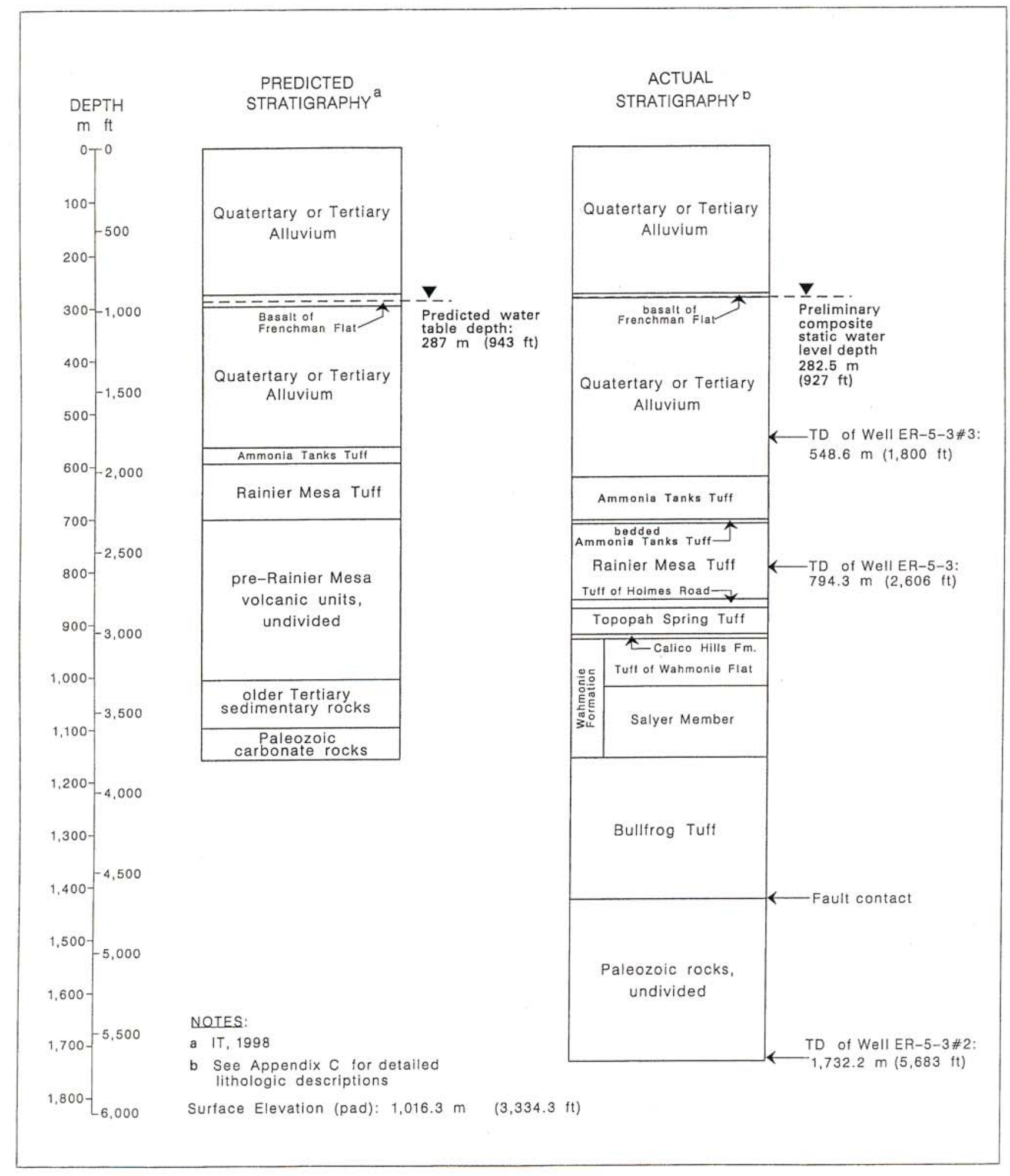

Figure 5-6

Predicted and Actual Stratigraphy at Well Cluster ER-5-3 
the Paleozoic rocks structurally elevated in the footwall of the fault. Within the volcanic section, the interval of Ammonia Tanks and Rainier Mesa Tuffs that makes up the upper portion of the volcanic section (consisting mostly of welded ash-flow tuff) is $227.7 \mathrm{~m}$ (747 ft) thick, or $90.5 \mathrm{~m}$ (297 ft) thicker than predicted. Although not predicted to be present in the subsurface at the well cluster site, the occurrence of Topopah Spring Tuff (consisting of partially to densely welded ash-flow tuff) is not surprising because it is present as surface exposures in the highlands north of the well cluster. The absence of pre-Bullfrog volcanic rocks such as Tunnel Beds and older tuffs, appears to be due to these units being faulted out at this location. Likewise the older Tertiary sedimentary rocks that underlie the volcanic rocks and were predicted to be approximately $91.4 \mathrm{~m}$ (300 ft) thick at the well cluster are also likely faulted out.

A west-to-east cross section constructed through the well cluster site prior to drilling shows the well cluster located just west of a buried west-dipping normal fault (IT, 2000a). The location of this fault was based on stratigraphic correlations between drill hole U-11c\#1 and UE-11g Exploratory Hole \#1, located north of the well cluster site, that indicated a down-to-the west normal fault between these holes. It was predicted that a well drilled to the TD of 1,158.2 $\mathrm{m}$ $(3,800 \mathrm{ft})$ at this site would reach Paleozoic rocks, and its TD would be approximately $213.4 \mathrm{~m}$ (700 ft) above this fault. Information from Well ER-5-3\#2 and the 3-D seismic survey indicate that Well ER-5-3\#2 penetrated the fault at 1,425.9 m (4,678 ft), very near the predicted location of the fault (Figures 5-3, 5-4, and 5-5).

\subsection{Hydrogeology}

The rocks of Well Cluster ER-5-3 have been subdivided into hydrogeologic units, as illustrated in cross sections in Figures 5-7 and 5-8. The unaltered alluvium above $179.8 \mathrm{~m}$ (590 ft), although unsaturated, is classified hydrogeologically as an alluvial aquifer based on its lithologic character. Below $179.8 \mathrm{~m}$ (590 ft) the alluvium has undergone low-grade zeolitic alteration. Although still considered an aquifer, this section of altered alluvium probably has somewhat less ability to transmit water than the overlying unaltered alluvium. The basalt encountered within the alluvium from 275.2 to $283.8 \mathrm{~m}$ (903 to $931 \mathrm{ft}$ ) forms a lava-flow aquifer. Information from nearby drill holes and surface magnetic surveys suggest that the basalt is limited in thickness and extent in the vicinity of Well Cluster ER-5-3, and thus is likely a minor and local hydrogeologic unit in the vicinity of the well cluster. The welded ash-flow tuffs that occur in the upper portion of the volcanic section above $914.4 \mathrm{~m}(3,000 \mathrm{ft})$ form welded tuff aquifers. Severe lost circulation and borehole instability experienced while drilling these welded tuff intervals suggest that they are highly fractured and likely form substantial aquifers in the vicinity of the well cluster. The volcanic rocks below $914.4 \mathrm{~m}$ (3,000 ft) consist mostly of bedded and poorly 

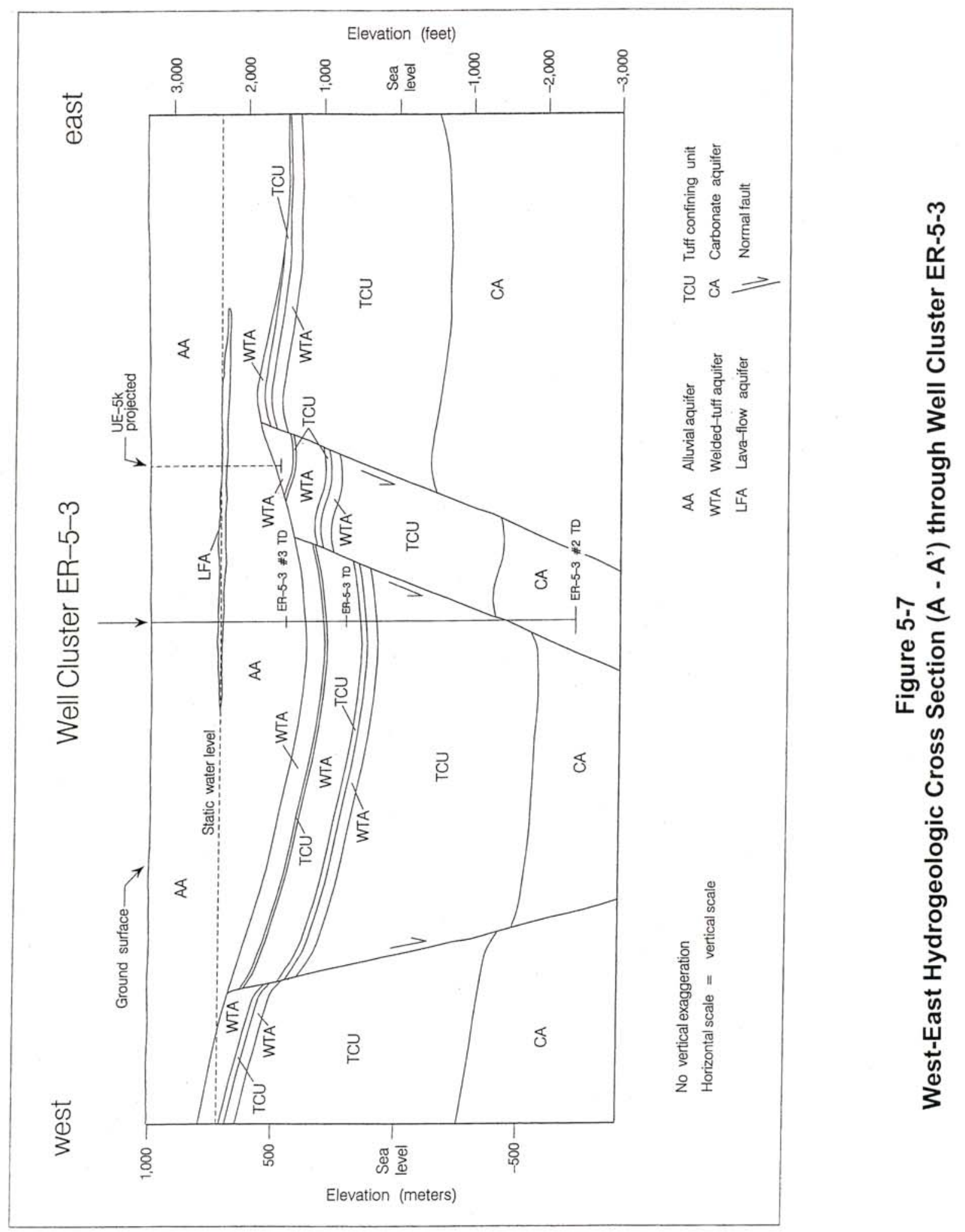


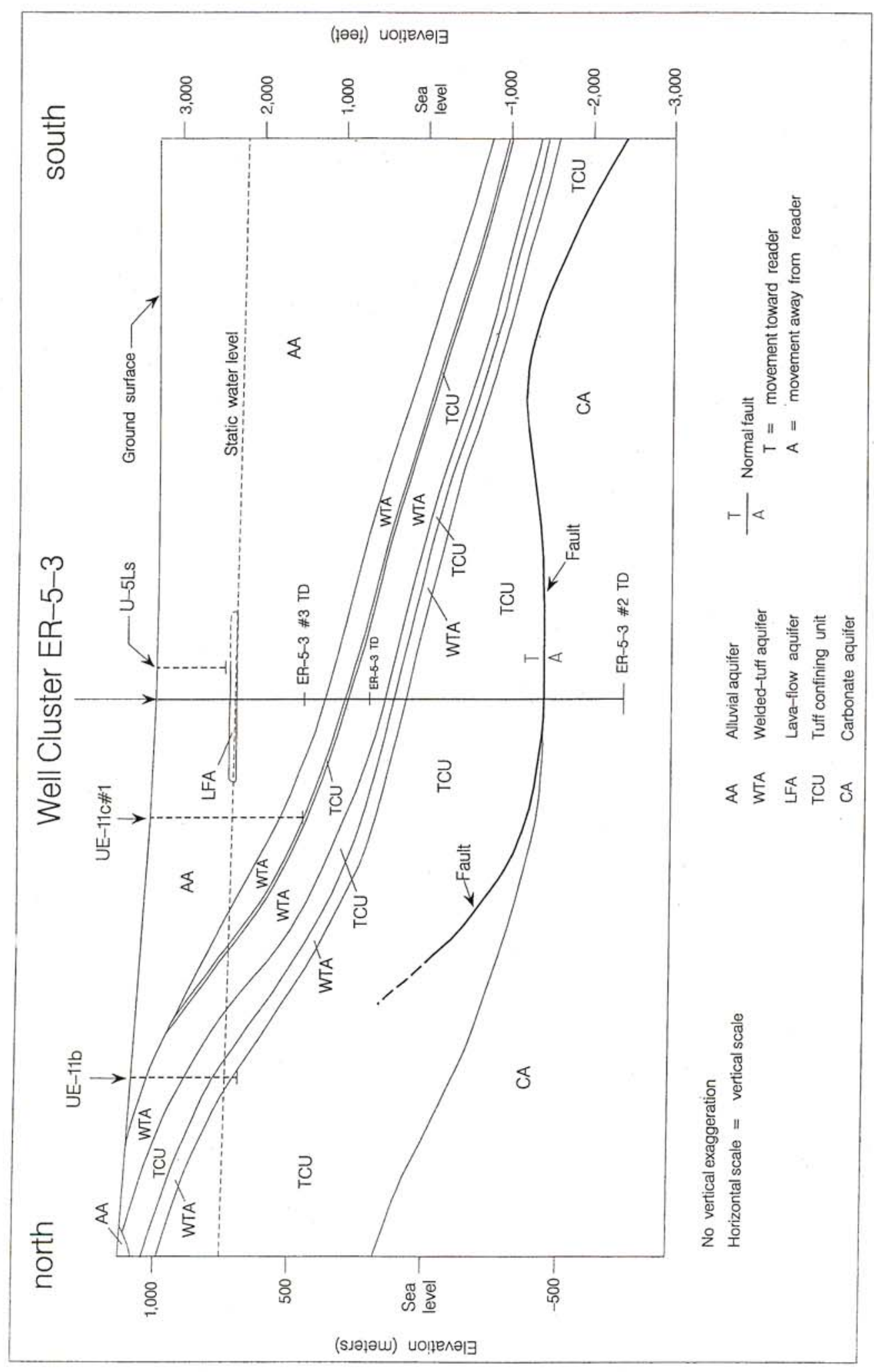

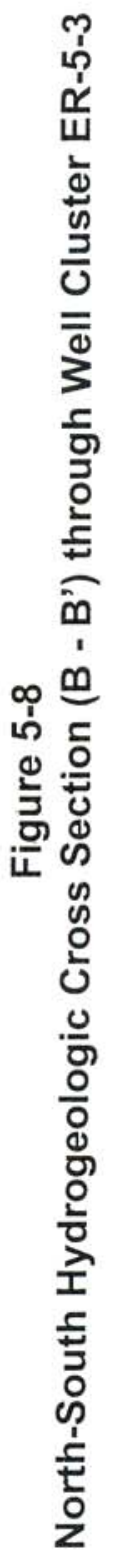


welded zeolitic tuffs that form a 511.5-m (1,678-ft) thick tuff confining unit at the well cluster site. The dolomite encountered below the volcanic section at 1,425.9 $\mathrm{m}(4,678 \mathrm{ft})$ represents the top of the regional carbonate aquifer.

Composite water levels in the two shallower wells ER-5-3 and ER-5-3\#3, which reached TD in volcanic rocks and alluvium respectively, are at $282.6 \mathrm{~m}$ (927 ft), very near the base of the basalt. No water level measurements were made in Well ER-5-3\#2 (during the drilling and completion operations covered in this report) after it reached the carbonate rocks, but when these measurements are made during planned hydrologic testing and sampling (reported elsewhere), it is expected that the water level in the carbonate rocks would be 9 to $15 \mathrm{~m}$ (30 to $50 \mathrm{ft}$ ) lower than the composite water level, based on experience in this area. 
This page intentionally left blank. 


\subsection{Summary, Recommendations, and Lessons Learned from Well Cluster ER-5-3}

\subsection{Summary}

Operations commenced at Well Cluster ER-5-3 with the drilling and completion of Well ER-5-3 in February 2000, followed by drilling and completion of Well ER-5-3\#2 in March and April 2000. Well ER-5-3\#3 was drilled in February 2001, immediately followed by recompletion of Well ER-5-3\#2 in March 2001. Drilling and completion activities at the well cluster were concluded on March 20, 2001.

Subcontractor activities at Well ER-5-3 commenced on February 22, 2000, and concluded on March 7, 2000, when the TD of $794.3 \mathrm{~m}$ (2,606 ft) was reached. After drilling and geophysical logging of the intermediate hole, a piezometer string was installed in the annulus of the intermediate casing string, at the depth of $376.9 \mathrm{~m}(1,236.7 \mathrm{ft})$. When the borehole had reached TD and additional geophysical logs had been run, another piezometer and the completion string were installed and gravel-packed, and the hole was stemmed to the depth of $271.3 \mathrm{~m}$ (890 ft) on March 13 to 16, 2000. The second piezometer string of 27/8-in. tubing was landed at $674.2 \mathrm{~m}$ $(2,12.0 \mathrm{ft})$. The $5 \frac{1}{2} /$-in. stainless-steel production casing was landed at $777.6 \mathrm{~m}(2,551.3 \mathrm{ft})$, and has two slotted intervals, at 451.0 to $529.5 \mathrm{~m} \mathrm{(1,479.7} \mathrm{to} 1,737.1 \mathrm{ft})$ and 737.8 to $777.0 \mathrm{~m}$ $(2,420.5$ to 2,549.1 ft). Crews worked on a schedule of seven days per week, 24 hours per day, for most of the operation. Twenty-four working days were expended to drill the surface and main holes, conduct geophysical logging, and install the completion string. Severe difficulties with borehole sloughing forced early termination of this first borehole in the cluster.

Drilling of Well ER-5-3\#2 commenced on March 23, 2000, and concluded on May 4, 2000, at the TD of 1,732.2 $\mathrm{m}$ (5,683 ft) had been reached. Due to problems with borehole sloughing, the slots of the single production string of 51/2-in. stainless-steel casing that was landed at $1,496.0 \mathrm{~m}$ $(4,908.0 \mathrm{ft})$ could not be placed as planned within an isolated interval in the lower carbonate aquifer, so the well was recompleted in March 2001. At that time the upper slots that were open to the tuff confining unit were sealed with cement and the lower slots were opened to allow access to the lower carbonate aquifer. Fifty-eight working days were expended to drill the surface and main holes, conduct geophysical logging and install the completion strings. The recompletion activities took place over 8 working days, with the crew working on a 4-days-perweek, 10-hours-per-day schedule. 
Drilling of Well ER-5-3\#3 began on January 31, 2001, and concluded on February 3, 2001, at the TD of $548.6 \mathrm{~m}(1,800)$. A string of $27 / 8$-in. tubing was landed at the depth of $531.9 \mathrm{~m}$ $(1,745.0 \mathrm{ft})$ and the hole stemmed to the depth of $250.9 \mathrm{~m}$ (823 ft) on February 5, 2001. This tubing is slotted in the interval 454.8 to $531.6 \mathrm{~m} \mathrm{(1,492.0}$ to 1,744.0 ft). It required 6 working days to drill the surface and main holes and install the completion string.

No radionuclides above background were encountered in the groundwater produced from any of the boreholes in Well Cluster ER-5-3. Preliminary (field-monitoring) data for the drilling effluent indicated no lead above permitted levels for dissolved lead.

IT personnel obtained a fluid level of approximately $282.6 \mathrm{~m}$ (927 ft) in each of the 3 wells, prior to planned future development and testing.

Composite drill cuttings were collected every $3 \mathrm{~m}$ (10 ft) below the conductor casing during drilling of all 3 boreholes. A total of 120 sidewall core samples was taken in Wells ER-5-3 and ER-5-3\#2 at various depths between 91.4 and 1,443.8 m (300 and 4,737 ft). No sidewall samples were collected from Well ER-5-3\#3. Open-hole geophysical logging was conducted at various stages of drilling of Wells ER-5-3 and ER-5-3\#2 to verify the geology and determine the hydrologic characteristics of the rocks; some logs also aided in the construction of the well by indicating borehole volume and condition, cement location, and borehole deviation. In Well ER-5-3\#3 geophysical logging was done only to monitor emplacement of stemming materials and to measure borehole deviation.

A single string of production casing with 2 gravel-packed, slotted intervals was installed in Well ER-5-3. The 51/2-in. stainless-steel production casing installed below the water table is suspended from $75 / 8$-in. carbon-steel casing (with an internal epoxy coating) which extends to the surface. The open intervals in the 51/2-in. casing are centered within the gravel-packed sections that are located at 447.1 to $543.2 \mathrm{~m}$ (1,467 to $1,782 \mathrm{ft}$ ) and 733.3 to $780.0 \mathrm{~m}$ (2,406 to 2,559 ft). These intervals are open to welded tuff lithologies of the Ammonia Tanks and Rainier Mesa Tuffs. Two $27 / 8$-in. piezometer tubing strings were also installed, each with one gravel-packed, slotted interval in the alluvial aquifer. The open interval in the lower string is centered within the gravel-packed interval located at 616.9 to $681.1 \mathrm{~m}$ (2,024 to 2,235 ft). The open interval in the upper string is centered within the gravel-packed interval located at 278.0 to $308.5 \mathrm{~m}$ (912 to $1,012 \mathrm{ft}$ ). 
A single string of production casing with 1 slotted interval was installed in Well ER-5-3\#2. The $5 \frac{1}{2}$-in. stainless-steel production casing installed below the water table is suspended from $75 / 8$-in. carbon-steel casing (with an internal epoxy coating) which extends to the surface. The open slots in the 51/2-in. casing are located at the depth of 1,426.5 to $1,495.4 \mathrm{~m}$ (4,680 to 4,906.1 ft) within fill material within the lower carbonate aquifer.

A single monitoring string of 27/8-in. tubing was installed in Well ER-5-3\#3. This string has one gravel-packed, slotted interval in the alluvial aquifer, centered within the gravel-packed interval located at 443.8 to $547.1 \mathrm{~m}$ (1,456 to 1,795 ft).

\subsection{Recommendations}

All geologic, geophysical, and hydrologic information, including results from well development activities, from Well Cluster ER-5-3 should be used to refine hydrogeologic models of Frenchman Flat.

\subsection{Lessons Learned}

When drilling through intervals prone to sloughing and high water production, the installation of additional casing strings and/or cement plugs may help stabilize the borehole. This contingency should be planned for by starting with a large-enough conductor hole to permit "sizing down" and installing casing strings.

Care must be taken when installing a tubing string in a small annular space between the borehole and casing, so that rock fragments are not entrained that may damage or obstruct the tubing during installation. 
This page intentionally left blank. 


\subsection{References}

Barnes, H., E. B. Ekren, C. L. Rodgers, and D. S. Hedlund, 1982. "Geology and Tectonic Maps for the Mercury Quadrangle, Nye and Clark Counties, Nevada,” U.S. Geological Survey, Miscellaneous Geologic Investigations Series Map I-1197, scale 1:24,000.

Bechtel Nevada, 1999. Western Pahute Mesa/Oasis Valley (WPM-OV) Investigation Wells SiteSpecific Health and Safety Plan (SSHASP). February 1999. Las Vegas, NV.

Bechtel Nevada, 2000a. Drilling Program for Underground Test Area (UGTA) Frenchman Flat Investigation Well ER-5-3 - Original. Drilling Work Plan Number D-002-001.00. February 18, 2000. Las Vegas, NV.

Bechtel Nevada, 2000b. Drilling Program for Underground Test Area (UGTA) Frenchman Flat Investigation Well ER-5-3\#2 - Original. Drilling Work Plan Number D-003-001.00. March 18, 2000. Las Vegas, NV.

Bechtel Nevada, 2001a. Main-Hole Drilling and Completion of UGTA Investigation Well ER-5-3\#3 - Original. Field Activity Work Plan Number D-001-003.01. January 19, 2001. Las Vegas, NV.

Bechtel Nevada, 2001b. UGTA Project Health and Safety Plan (HASP), January 2001. Las Vegas, NV.

Bechtel Nevada, 2001c. Completion Program for Underground Test Area (UGTA) Frenchman Flat Investigation Well ER-5-3\#2 - Original. Field Activity Work Plan Number D-003-001.01. March 5, 2001. Las Vegas, NV.

BN, see Bechtel Nevada.

Byers, F. M. Jr., and C. H. Miller, 1966. Geologic and Geophysical Log of the Ue5k Exploratory Hole, Frenchman Flat, Nevada Test Site. U.S. Geological Survey Technical Letter NTS-164.

Dixon, G. L., W. J. Carr, and W. P. Williams, 1967. Geologic and Geophysical Log of Drill Hole Ue5i, Nevada Test Site. U.S. Geological Survey Technical Letter NTS-157.

DOE, see U.S. Department of Energy.

GBEC, see Great Basin Exploration Consultants.

Grauch, V. J. S., and M. R. Hudson, 1995. Written communication prepared for DOE/NV. Subject: "Preliminary Analysis of Major Structures and Lithologic Boundaries for the Frenchman Flat Model Area.” U.S. Geological Survey, Denver, CO. 
Great Basin Exploration Consultants, 2002. Written communication prepared for Bechtel Nevada, Las Vegas, NV. Subject: "Frenchman Flat 3D Seismic Survey, ER-5-4\#2 Synthetic Seismogram, Time-Depth Curve, and Correlation with Seismic Data, Nevada Test Site, Nevada, August 16, 2002. Lakewood, CO.

Hinrichs, E. N., 1968. “Geologic Map of the Camp Desert Rock Quadrangle, Nye County, Nevada,” U.S. Geological Survey Geologic Quadrangle Map G-726, scale 1:24,000.

Hinrichs, E. N., and E. J. McKay, 1965. “Geologic Map of the Plutonium Valley Quadrangle, Nye and Lincoln Counties, Nevada,” U.S. Geological Survey Geologic Quadrangle Map 384, scale $1: 24,000$.

Hudson, M. R., 1992. "Paleomagnetic Data Bearing on the Origin of Arcuate Structures in the French Peak-Massachusetts Mountain Area of Southern Nevada.” Geological Society of America Bulletin, v. 104, pp. 581-594.

IT, see IT Corporation.

IT Corporation, 2000a. Frenchman Flat Hydrogeologic Investigation Wells Drilling and Completion Criteria, Revision 0. ITLV/13052--094. Las Vegas, NV.

IT Corporation. 2000b. Written communication prepared for NNSA/NV. Subject: "Frenchman Flat Well Cluster ER-5-3 Data Report,” September 2000. Las Vegas, NV.

IT Corporation, 2001a. Frenchman Flat Hydrogeologic Investigation Wells Drilling and Completion Criteria, Revision 1. ITLV/13052--094-REV.1-ADD. Las Vegas, NV.

IT Corporation. 2001b. Written communication prepared for NNSA/NV, Las Vegas, NV. Subject: “Addendum to the Frenchman Flat Well Cluster ER-5-3 Data Report,” August 2001. Las Vegas, NV.

Liebendorfer, P. J., Nevada Division of Environmental Protection. 2001. Letter to R. C. Wycoff (DOE/NV). Subject: “U.S. Department of Energy’s Request for a Fluid Management Plan (FMP) Waiver for the ER-5-3, ER-5-3\#2, and ER-5-3\#3 Wells in Frenchman Flat, February 15, 2001. Carson City, NV.

McKeown, F. A., D. L. Healey, and C. H. Miller, 1976. “Geologic Map of the Yucca Lake Quadrangle, Nye County, Nevada,” U.S. Geological Survey Geologic Quadrangle Map GQ-1327, scale 1:24,000.

Phelps, G. A., and S. E. Graham, 2002. "Preliminary Gravity Inversion Model of Frenchman Flat Basin, Nevada Test Site,” U.S. Geological Survey Open-File Report 02-363.

Poole, F. G., 1965. “Geologic Map of the Frenchman Flat Quadrangle, Nye and Lincoln Counties, Nevada,” U.S. Geological Survey Geologic Quadrangle Map GC-456, scale $1: 24,000$. 
Poole, F. G., D. P. Elston, and W. J. Carr, 1965. “Geologic Map of the Cane Spring Quadrangle, Nye County, Nevada,” U.S. Geological Survey Geologic Quadrangle Map GQ-455, scale $1: 24,000$.

Prothro, L. B., 2002. Written communication prepared for NNSA/NV, Las Vegas, NV. Subject: "Geologic Interpretation of the Frenchman Flat 3-D Seismic Data, Summary Report." Bechtel Nevada informal report. August 2002. Las Vegas, NV.

Prothro, L. B., and S. L. Drellack, Jr., 1997. Review and Reconnaissance of the Hydrogeology of Tertiary Sedimentary Rocks in the Vicinity of Frenchman Flat, Nevada Test Site. DOE/NV/11718--155. Las Vegas, NV.

Sawyer, D. A., R. J. Fleck, M. A. Lanphere, R. G. Warren, and D. E. Broxton, 1994. Episodic Caldera Volcanism in the Miocene Southwest Nevada Volcanic Field: Revised Stratigraphic Caldera Framework, ${ }^{40} \mathrm{Ar} /{ }^{39} \mathrm{Ar}$ Geochronology and Implications for Magmatism and Extension. Geological Society of America Bulletin, v. 67, n. 10, pp. 1,304-1,318.

Slate, J. L., M. E. Berry, P. D. Rowley, C. J. Fridrich, K. S. Morgan, J. B. Workman, O. D. Young, G. L. Dixon, V. S. Williams, E. H. McKee, D. A. Ponce, T. G. Hildenbrand, WC Swadley, S. C. Lundstrom, E. B. Ekren, R. G. Warren, J. C. Cole, R. J. Fleck, M. A. Lanphere, D. A. Sawyer, S. A. Minor, D. J. Grunwald, R. J. Laczniak, C. M. Menges, J. C. Yount, and A. S. Jayko, 1999. Digital Geologic Map of the Nevada Test Site and Vicinity, Nye, Lincoln, and Clark Counties, Nevada, and Inyo County, California. U.S. Geological Survey Open-File Report 99-554-A, scale 1:120,000.

Tschanze, C. M. and E. H. Pampeyan, 1970. Geology and Mineral Deposits of Lincoln County, Nevada. Nevada Bureau of Mines and Geology Bulletin 73.

U.S. Department of Energy, Nevada Operations Office. 1996. Underground Test Area Subproject Waste Management Plan, Rev. 1, DOE/NV--343. Las Vegas, NV.

U.S. Department of Energy, Nevada Operations Office. 1998. Nevada Environmental Restoration Project Health and Safety Plan, Revision 3, February 1998. Las Vegas, NV.

U.S. Department of Energy, Nevada Operations Office, 1999. "Fluid Management Plan for the Underground Test Area Project,” DOE/NV--370, Rev. 2. In Underground Test Area Subproject Waste Management Plan, Rev. 1, DOE/NV--343. Las Vegas, NV.

Warren, R. G., Los Alamos National Laboratory, 2000. Personal communication to Lance Prothro, Bechtel Nevada, Las Vegas, NV, dated December 21, 2000. Subject: Preliminary stratigraphy and alteration for Wells ER-5-3 and ER-5-3\#2.

Warren, R. G., F. C. Benedict Jr., T. P. Rose, D. K. Smith, S. J. Chipera, E. C. Kluk, and K. M. Raven, 2002. “Alluvial Layering and Distribution of Reactive Phases within Drill Holes ER5/4 and UE5n of Frenchman Flat. Los Alamos National Laboratory Report LA-UR-02-6206. Los Alamos, NM. 
This page intentionally left blank. 


\section{Appendix A Drilling Data}

A-1 Drilling Parameter Logs for Well Cluster ER-5-3

A-2 Casing Data for Well Cluster ER-5-3

A-3 Well Cluster ER-5-3 Drilling Fluids and Cement Composition 


\section{Appendix A-1 \\ Drilling Parameter Logs for Well Cluster ER-5-3}




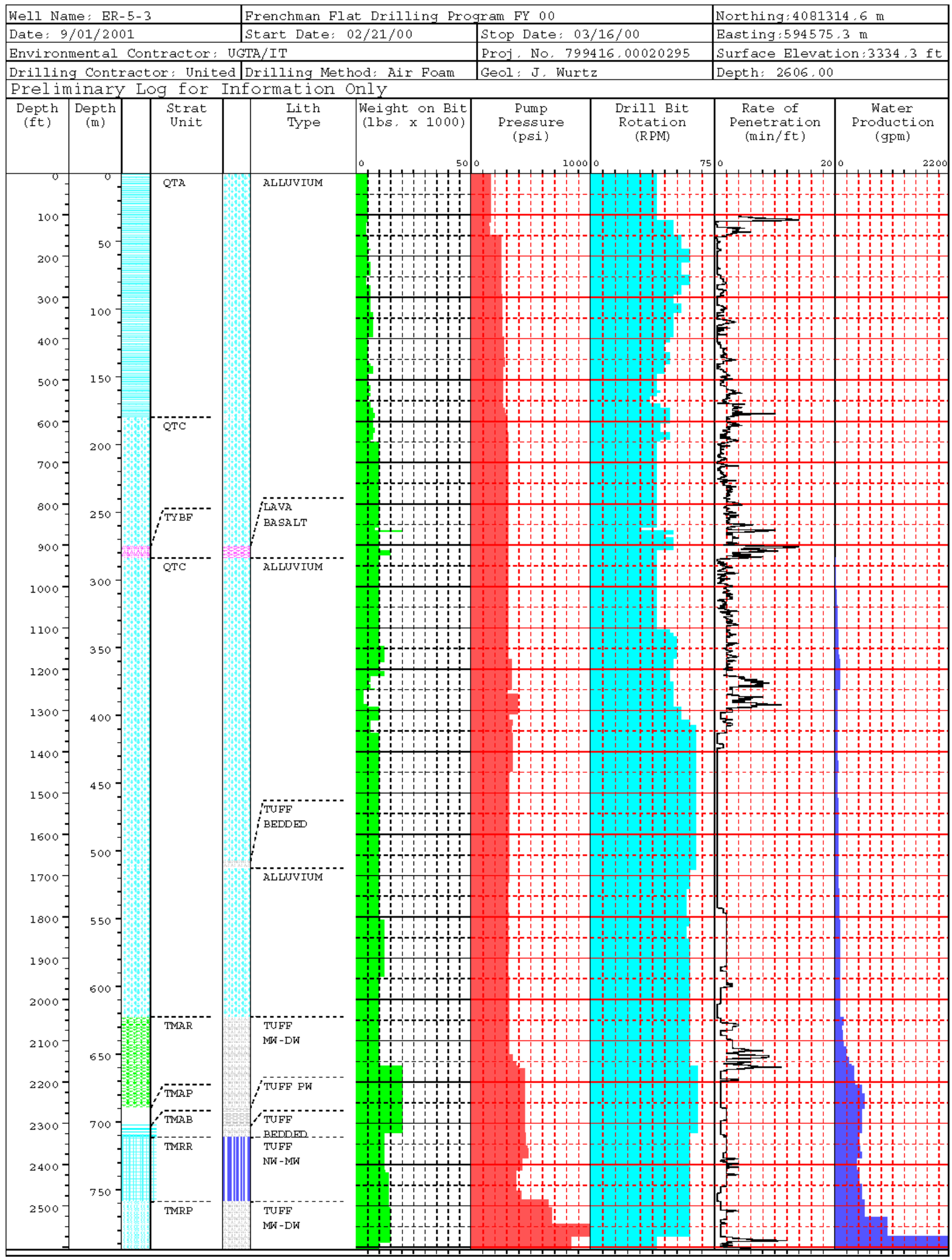




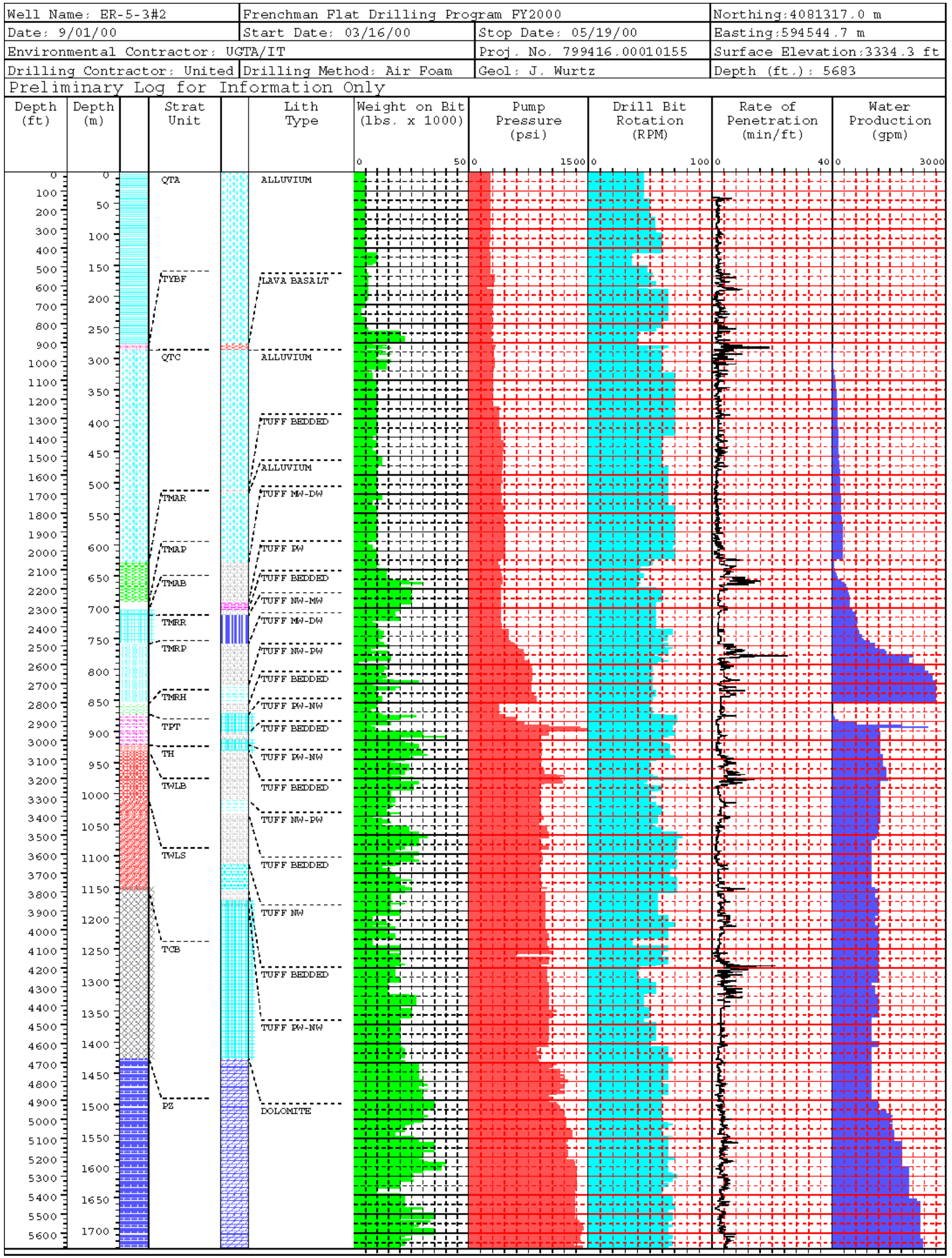




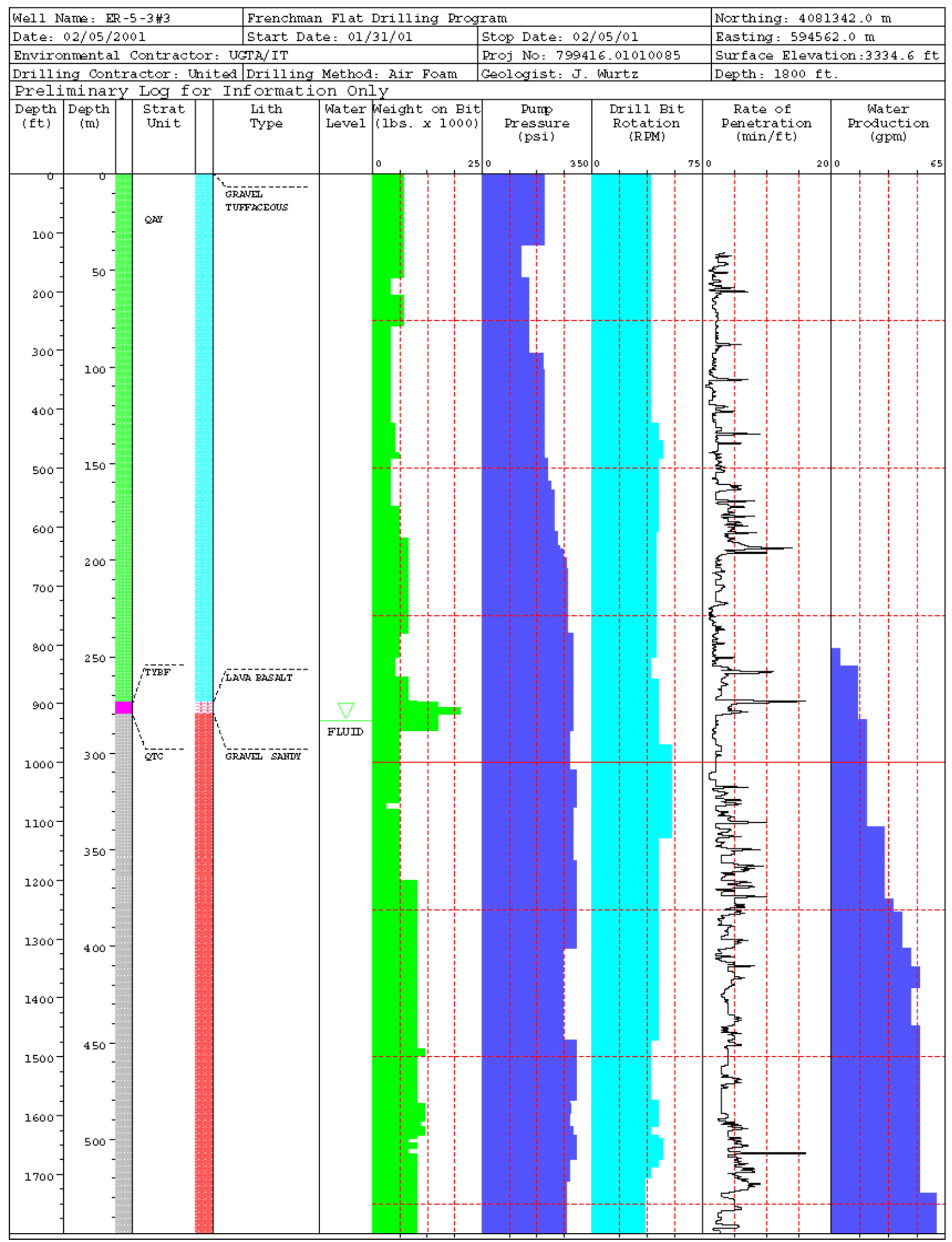


This page intentionally left blank.

A-1-4 
Appendix A-2

Casing and Tubing Data for Well Cluster ER-5-3 
Table A-2-1

Casing and Tubing Data for Well ER-5-3

\begin{tabular}{|c|c|c|c|c|c|c|c|}
\hline $\begin{array}{l}\text { Casing and } \\
\text { Tubing }\end{array}$ & $\begin{array}{l}\text { Depth Interval } \\
\text { meters } \\
\text { (feet) }\end{array}$ & Type & Grade & $\begin{array}{l}\text { Outside } \\
\text { Diameter } \\
\text { centimeters } \\
\text { (inches) }\end{array}$ & $\begin{array}{c}\text { Inside } \\
\text { Diameter } \\
\text { centimeters } \\
\text { (inches) }\end{array}$ & $\begin{array}{c}\text { Wall } \\
\text { Thickness } \\
\text { centimeters } \\
\text { (inches) }\end{array}$ & $\begin{array}{l}\text { Weight } \\
\text { per foot } \\
\text { (pounds) }\end{array}$ \\
\hline $\begin{array}{c}\text { 66-inch } \\
\text { Conductor Casing }\end{array}$ & $\begin{array}{l}0 \text { to } 2.4 \\
(0 \text { to } 8)\end{array}$ & Carbon Steel & A36 & $\begin{array}{c}167.64 \\
(66)\end{array}$ & $\begin{array}{l}165.56 \\
(65.18)\end{array}$ & $\begin{array}{l}2.08 \\
(0.82)\end{array}$ & 574 \\
\hline $\begin{array}{l}\text { 30-inch } \\
\text { Conductor } \\
\text { Casing }\end{array}$ & $\begin{array}{c}0 \text { to } 31.1 \\
(0 \text { to } 102.0)\end{array}$ & $\begin{array}{l}\text { Carbon Steel } \\
\text { PE Weld }\end{array}$ & K55 & $\begin{array}{l}76.2 \\
(30)\end{array}$ & $\begin{array}{c}74.295 \\
(29.250)\end{array}$ & $\begin{array}{l}0.953 \\
(0.375)\end{array}$ & 118.65 \\
\hline Surface Casing & $\begin{array}{c}0 \text { to } 374.8 \\
(0 \text { to } 1,229.6)\end{array}$ & Carbon Steel & J55 & $\begin{array}{c}33.97 \\
(13.375)\end{array}$ & $\begin{array}{c}32.042 \\
(12.615)\end{array}$ & $\begin{array}{c}0.965 \\
(0.380)\end{array}$ & 54.5 \\
\hline $\begin{array}{c}\text { Completion } \\
\text { Casing } \\
\text { (with cross-over) }\end{array}$ & $\begin{array}{c}0 \text { to } 437.2 \\
(0 \text { to } 1,434.4)\end{array}$ & $\begin{array}{l}\text { Carbon Steel } \\
\text { with internal } \\
\text { epoxy coating }\end{array}$ & N80 & $\begin{array}{l}19.37 \\
(7.625)\end{array}$ & $\begin{array}{l}17.701 \\
(6.969)\end{array}$ & $\begin{array}{c}0.833 \\
(0.328)\end{array}$ & 26.4 \\
\hline $\begin{array}{l}\text { Completion } \\
\text { Casing }\end{array}$ & $\begin{array}{c}437.2 \text { to } 777.6 \\
(1,434.4 \text { to } 2,551.3)\end{array}$ & $\begin{array}{l}\text { Stainless } \\
\text { Steel }\end{array}$ & SSTP304 & $\begin{array}{l}14.13 \\
(5.563)\end{array}$ & $\begin{array}{l}12.819 \\
(5.047)\end{array}$ & $\begin{array}{c}0.655 \\
(0.258)\end{array}$ & 14.6 \\
\hline $\begin{array}{l}\text { Piezometer } \\
\text { String \#1 }\end{array}$ & $\begin{array}{c}0 \text { to } 376.9 \\
(0 \text { to } 1,236.7)\end{array}$ & $\begin{array}{l}\text { Stainless } \\
\text { Steel }\end{array}$ & SSTP304 & $\begin{array}{l}7.303 \\
(2.875)\end{array}$ & $\begin{array}{c}6.20 \\
(2.441)\end{array}$ & $\begin{array}{c}0.551 \\
(0.217)\end{array}$ & 6.4 \\
\hline $\begin{array}{l}\text { Piezometer } \\
\text { String \#2 }\end{array}$ & $\begin{array}{c}0 \text { to } 674.2 \\
(0 \text { to } 2,212.0)\end{array}$ & $\begin{array}{l}\text { Stainless } \\
\text { Steel }\end{array}$ & T304 & $\begin{array}{c}7.393 \\
(2.875)\end{array}$ & $\begin{array}{c}5.90 \\
(2.323)\end{array}$ & $\begin{array}{c}0.70 \\
(0.276)\end{array}$ & 7.66 \\
\hline
\end{tabular}

Table A-2-2

Casing Data for Well ER-5-3\#2

\begin{tabular}{|c|c|c|c|c|c|c|c|}
\hline Casing & $\begin{array}{l}\text { Depth Interval } \\
\text { meters } \\
\text { (feet) }\end{array}$ & Type & Grade & $\begin{array}{c}\text { Outside } \\
\text { Diameter } \\
\text { centimeters } \\
\text { (inches) }\end{array}$ & $\begin{array}{c}\text { Inside } \\
\text { Diameter } \\
\text { centimeters } \\
\text { (inches) }\end{array}$ & $\begin{array}{c}\text { Wall } \\
\text { Thickness } \\
\text { centimeters } \\
\text { (inches) }\end{array}$ & $\begin{array}{l}\text { Weight } \\
\text { per foot } \\
\text { (pounds) }\end{array}$ \\
\hline $\begin{array}{l}\text { Conductor } \\
\text { Casing }\end{array}$ & $\begin{array}{c}0 \text { to } 36.0 \\
(0 \text { to } 118.0)\end{array}$ & $\begin{array}{l}\text { Carbon Steel } \\
\text { PE Weld }\end{array}$ & N/A & $\begin{array}{l}76.2 \\
(30)\end{array}$ & $\begin{array}{c}74.295 \\
(29.250)\end{array}$ & $\begin{array}{c}0.953 \\
(0.375)\end{array}$ & 118.65 \\
\hline Surface Casing & $\begin{array}{c}0 \text { to } 613.8 \\
(0 \text { to } 2,013.8)\end{array}$ & Carbon Steel & K55 & $\begin{array}{l}50.8 \\
(20)\end{array}$ & $\begin{array}{c}48.26 \\
(19)\end{array}$ & $\begin{array}{l}1.27 \\
(0.5)\end{array}$ & $106 / 94$ \\
\hline $\begin{array}{l}\text { Intermediate } \\
\text { Casing }\end{array}$ & $\begin{array}{c}0 \text { to } 849.0 \\
(0 \text { to } 2,785.5)\end{array}$ & Carbon Steel & K55 & $\begin{array}{c}33.97 \\
(13.375)\end{array}$ & $\begin{array}{c}32.042 \\
(12.615)\end{array}$ & $\begin{array}{c}0.965 \\
(0.380)\end{array}$ & $61 / 54.5$ \\
\hline $\begin{array}{c}\text { Completion } \\
\text { Casing } \\
\text { (with cross-over) }\end{array}$ & $\begin{array}{c}0 \text { to } 754.9 \\
(0 \text { to } 2,476.8)\end{array}$ & $\begin{array}{l}\text { Carbon Steel } \\
\text { with internal } \\
\text { epoxy coating }\end{array}$ & N80 & $\begin{array}{c}19.37 \\
(7.625)\end{array}$ & $\begin{array}{l}17.701 \\
(6.969)\end{array}$ & $\begin{array}{c}0.833 \\
(0.328)\end{array}$ & 26.4 \\
\hline $\begin{array}{l}\text { Completion } \\
\text { Casing }\end{array}$ & $\begin{array}{c}754.9 \text { to } 1,496.0 \\
(2,476.6 \text { to } 4,908.2)\end{array}$ & $\begin{array}{l}\text { Stainless } \\
\text { Steel }\end{array}$ & SSTP304 & $\begin{array}{c}14.13 \\
(5.563)\end{array}$ & $\begin{array}{l}12.819 \\
(5.047)\end{array}$ & $\begin{array}{c}0.655 \\
(0.258)\end{array}$ & 14.6 \\
\hline
\end{tabular}


Table A-2-3

Casing and Tubing Data for Well ER-5-3\#3

\begin{tabular}{||c|c|c|c|c|c|c|c||}
\hline Casing & $\begin{array}{c}\text { Depth Interval } \\
\text { meters } \\
\text { (feet) }\end{array}$ & Type & Grade & $\begin{array}{c}\text { Outside } \\
\text { Diameter } \\
\text { centimeters } \\
\text { (inches) }\end{array}$ & $\begin{array}{c}\text { Inside } \\
\text { Diameter } \\
\text { centimeters } \\
\text { (inches) }\end{array}$ & $\begin{array}{c}\text { Wall } \\
\text { Thickness } \\
\text { centimeters } \\
\text { (inches) }\end{array}$ & $\begin{array}{c}\text { Weight } \\
\text { per foot } \\
\text { (pounds) }\end{array}$ \\
\hline \hline Conductor Casing & $\begin{array}{c}0 \text { to } 35.7 \\
\text { (0 to } 117.0)\end{array}$ & Carbon Steel & H-40 & $\begin{array}{c}40.64 \\
(16.0)\end{array}$ & $\begin{array}{c}38.74 \\
(15.25)\end{array}$ & $\begin{array}{c}0.95 \\
(0.375)\end{array}$ & 65 \\
\hline $\begin{array}{c}\text { Completion } \\
\text { Tubing }\end{array}$ & $\begin{array}{c}0 \text { to } 454.5 \\
(0 \text { to } 1,491.1)\end{array}$ & Carbon Steel & N80 & $\begin{array}{c}7.303 \\
(2.875)\end{array}$ & $\begin{array}{c}6.20 \\
(2.441)\end{array}$ & $\begin{array}{c}0.551 \\
(0.217)\end{array}$ & 6.4 \\
\hline $\begin{array}{c}\text { Completion } \\
\text { Tubing }\end{array}$ & $\begin{array}{c}454.5 \text { to } 531.9 \\
(1,491.1 \text { to } 1,745.0\end{array}$ & $\begin{array}{c}\text { Stainless } \\
\text { Steel }\end{array}$ & SST-304 & $\begin{array}{c}7.303 \\
(2.875)\end{array}$ & $\begin{array}{c}5.90 \\
(2.323)\end{array}$ & $\begin{array}{c}0.702 \\
(0.276)\end{array}$ & 7.66 \\
\hline
\end{tabular}


Appendix A-3

Well Cluster ER-5-3 Drilling Fluids and Cement Composition 


\section{Table A-3-1 \\ Drilling Fluids Used in Well ER-5-3}

\begin{tabular}{|c|c|}
\hline Typical Air-Foam Mix ${ }^{a}$ & Typical Air-Foam/Polymer Mix ${ }^{a}$ \\
\hline $\begin{array}{c}11.4 \text { liters (3 gallons) Geofoam }{ }^{\circledR c} \\
\text { per } \\
7,949 \text { liters (50 barrels) water }\end{array}$ & $\begin{array}{c}30.3 \text { to } 75.5 \text { liters ( } 8 \text { to } 20 \text { gallons) Geofoam }{ }^{\circledR 0} \\
\text { and } \\
7.6 \text { to } 11.4 \text { liters ( } 2 \text { to } 3 \text { gallons) } \text { LP70 }^{\circledR \mathrm{C}} \\
\text { per } \\
7,949 \text { liters ( } 50 \text { barrels) water }\end{array}$ \\
\hline
\end{tabular}

a An air-foam ("soap") mix was used as the drilling fluid in Well ER-5-3. The hole was dry-augered to 32.0 meters (105 feet). No additives were used between the depths of approximately 32.0 and 45.7 meters (105 to 150 feet). Various proportions of polymer were added to the air-foam to suit conditions during drilling below approximately 45.7 meters (150 feet).

b $\quad$ Geofoam ${ }^{\circledR}$ foaming agent and LP701 ${ }^{\circledR}$ polymer additive are products of Geo Drilling Fluids, Inc.

NOTES:

1. All water used to mix drilling fluids for Well $E R-5-3$ came from Wells $5 B$ and $C-1$, located in Frenchman Flat and Yucca Flat, respectively.

2. A concentrated solution of lithium bromide was added to all introduced fluids to make up a final concentration of 13 to 134 milligrams per liter.

Table A-3-2

Drilling Fluids Used in Well ER-5-3\#2

\begin{tabular}{|c|c|c|}
\hline Typical Air-Foam Mix ${ }^{a}$ & Typical Air-Foam/Polymer Mix ${ }^{a}$ & Polymer Mix ${ }^{\text {b }}$ \\
\hline $\begin{array}{c}11.4 \text { liters ( } 3 \text { gallons) Geofoam }{ }^{\circledR C} \\
\text { per } \\
7,949 \text { liters ( } 50 \text { barrels) water }\end{array}$ & $\begin{array}{c}30.3 \text { to } 94.6 \text { liters (8 to } 25 \text { gallons) Geofoam }{ }^{\circledR} \\
\text { and } \\
3.8 \text { to } 15.1 \text { liters ( } 1 \text { to } 4 \text { gallons) } \mathrm{LP} 701^{\circledR \mathrm{C}} \\
\text { per } \\
7,949 \text { liters ( } 50 \text { barrels) water }\end{array}$ & $\begin{array}{c}0.68 \text { to } 0.91 \text { kilograms } \\
\text { (1.5 to } 2 \text { pounds) } \\
\text { Xanvis }^{\circledR \mathrm{c}} \\
\text { per } \\
159 \text { liters (1 barrel) water }\end{array}$ \\
\hline
\end{tabular}

a An air-foam ("soap") mix was used as the drilling fluid in Well ER-5-3\#2. The hole was dry-augered to 36.6 meters (120 feet). No additives were used between the depths of approximately 36.6 and 40.2 meters (120 to 132 feet). Various proportions of polymer were added to the air-foam to suit conditions during drilling below approximately 40.2 meters (132 feet).

b Slugs of a higher viscosity polymer mix were pumped down the borehole during geophysical logging, after the drilling was terminated at 1,732.2 meters (5,683 feet).

C $\quad$ Geofoam ${ }^{\circledR}$ foaming agent and LP70 $1^{\circledR}$ polymer additive are products of Geo Drilling Fluids, Inc. Xanvis ${ }^{\circledR}$ is a clarified xanthan gum polymer manufactured by Kelco Oil Field Group.

NOTES:

1. All water used to mix drilling fluids for Well ER-5-3\#2 came from Wells 5, 5B, and C-1, located in Frenchman Flat and Yucca Flat.

2. A concentrated solution of lithium bromide was added to all introduced fluids to make up a final concentration of 15 to 120 milligrams per liter. 


\section{Table A-3-3}

\section{Drilling Fluids Used in Well ER-5-3\#3}

\begin{tabular}{|c||}
\hline Air-Foam/Polymer Mix $^{\mathrm{a}}$ \\
\hline \hline 26.5 liters (7 gallons) Geofoam $^{\circledR \mathrm{C}}$ \\
and \\
7.6 liters (2 gallons) LP701 $^{\circledR \mathrm{C}}$ \\
per \\
7,949 liters (50 barrels) water \\
\hline
\end{tabular}

a An air-foam ("soap") mix was used as the drilling fluid in Well ER-5-3\#3. The hole was dry-augered to 36.6 meters (120 feet).

b $\quad$ Geofoam ${ }^{\circledR}$ foaming agent and LP701 ${ }^{\circledR}$ polymer additive are products of Geo Drilling Fluids, Inc.

NOTES:

1. All water used to mix drilling fluids for Well ER-5-3\#3 came from Wells 5, 5B, and C-1, located in Frenchman Flat and Yucca Flat.

2. A concentrated solution of lithium bromide was added to all introduced fluids to make up a final concentration of 20 to 64 milligrams per liter.

Table A-3-4

\section{Well ER-5-3 Cement Composition}

\begin{tabular}{|c|c|c|c|}
\hline Cement Composition & $\begin{array}{c}\text { 30-inch } \\
\text { Conductor Casing }\end{array}$ & $\begin{array}{c}\text { 13\%3-inch Surface } \\
\text { Casing and } \\
\text { Piezometer \#1 }\end{array}$ & $\begin{array}{c}\text { Production Casing and } \\
\text { Piezometer \#2 }\end{array}$ \\
\hline $\begin{array}{c}\text { Gypsum Cement } \\
\text { Type W-60 and Type II }\end{array}$ & Not used. & $\begin{array}{l}18.6 \text { to } 19.8 \mathrm{~m}^{\mathrm{c}} \\
(61 \text { to } 65 \mathrm{ft})\end{array}$ & Not used. \\
\hline Type II neat & $\begin{array}{l}0 \text { to } 32.0 \mathrm{~m} \\
(0 \text { to } 105 \mathrm{ft})\end{array}$ & $\begin{array}{c}0 \text { to } 18.6 \mathrm{~m} \\
(0 \text { to } 61 \mathrm{ft}) \\
319.4 \text { to } 374.9 \mathrm{~m}^{\mathrm{c}} \\
(1,048 \text { to } 1,230 \mathrm{ft})\end{array}$ & $\begin{array}{l}271.3 \text { to } 440.7 \mathrm{~m} \\
\text { (890 to } 1,446 \mathrm{ft}) \\
\\
543,2 \text { to } 608.1 \mathrm{~m} \\
(1,782 \text { to } 1,995) \\
\\
681.2 \text { to } 723.0 \mathrm{~m} \\
(2,235 \text { to } 2,372 \mathrm{ft})\end{array}$ \\
\hline
\end{tabular}
a meter(s)
b foot (feet)
c estimated 
Table A-3-5

Well ER-5-3\#2 Cement Composition

\begin{tabular}{|c|c|c|c|c|c|}
\hline $\begin{array}{c}\text { Cement } \\
\text { Composition }\end{array}$ & $\begin{array}{c}\text { 30-inch } \\
\text { Conductor Casing }\end{array}$ & $\begin{array}{c}20 \text {-inch } \\
\text { Surface Casing }\end{array}$ & $\begin{array}{c}\text { Cemented } \\
\text { Sloughing Zone }\end{array}$ & $\begin{array}{c}13^{3} / 8 \text {-inch } \\
\text { Intermediate Casing }\end{array}$ & Production Casing \\
\hline Type II neat & $\begin{array}{l}35.1 \text { to } 36.6 \mathrm{~m}^{\mathrm{a}} \\
\left(115 \text { to } 120 \mathrm{ft}^{\mathrm{b}}\right)\end{array}$ & $\begin{array}{l}0 \text { to } 528.2 \mathrm{~m} \\
(0 \text { to } 1,733 \mathrm{ft})\end{array}$ & $\begin{array}{c}\text { Approximately } \\
7.8 \mathrm{~m}^{3 \mathrm{c}} \\
\left(275 \mathrm{ft}^{3 \mathrm{~d}}\right) \text { at } \\
\text { depth of } 794.0 \mathrm{~m} \\
(2,605 \mathrm{ft})\end{array}$ & $\begin{array}{l}0 \text { to } 777.2 \mathrm{~m} \\
(0 \text { to } 2,550 \mathrm{ft})\end{array}$ & $\begin{array}{c}1,391.7 \text { to } 1,424.6 \mathrm{~m} \\
(4,566 \text { to } 4,674 \mathrm{ft})\end{array}$ \\
\hline $\begin{array}{c}\text { Type II with } \\
25 \% \text { Gypsum }\end{array}$ & $\begin{array}{l}0 \text { to } 36.6 \mathrm{~m} \\
(0 \text { to } 115 \mathrm{ft})\end{array}$ & Not used. & Not used. & Not used. & Not used. \\
\hline $\begin{array}{c}\text { Type II with } \\
\text { cedar, sand, } \\
\text { gravel }\end{array}$ & Not used. & $\begin{array}{l}\text { On cement } \\
\text { baskets }\end{array}$ & Not used. & Not used. & Not used. \\
\hline
\end{tabular}
a meters
b feet
c cubic meters
d cubic feet

Table A-3-6

Well ER-5-3\#3 Cement Composition

\begin{tabular}{||c|c|c||}
\hline Cement Composition & 16-inch Conductor Casing & Production Tubing \\
\hline \hline Type II neat & $\begin{array}{l}0 \text { to } 36.6 \mathrm{~m} \\
(0 \text { to } 120 \mathrm{ft})\end{array}$ & $\begin{array}{r}250.9 \text { to } 430.4 \mathrm{~m}^{\mathrm{c}} \\
(823 \text { to } 1,412 \mathrm{ft})\end{array}$ \\
\hline
\end{tabular}
a meter(s)
b foot (feet)
c estimated 
This page intentionally left blank.

A-3-4 


\section{Appendix B}

Well Cluster ER-5-3 Fluid Management Data 
Preliminary Analytical Results for Fluid Management Samples from Well Cluster ER-5-3

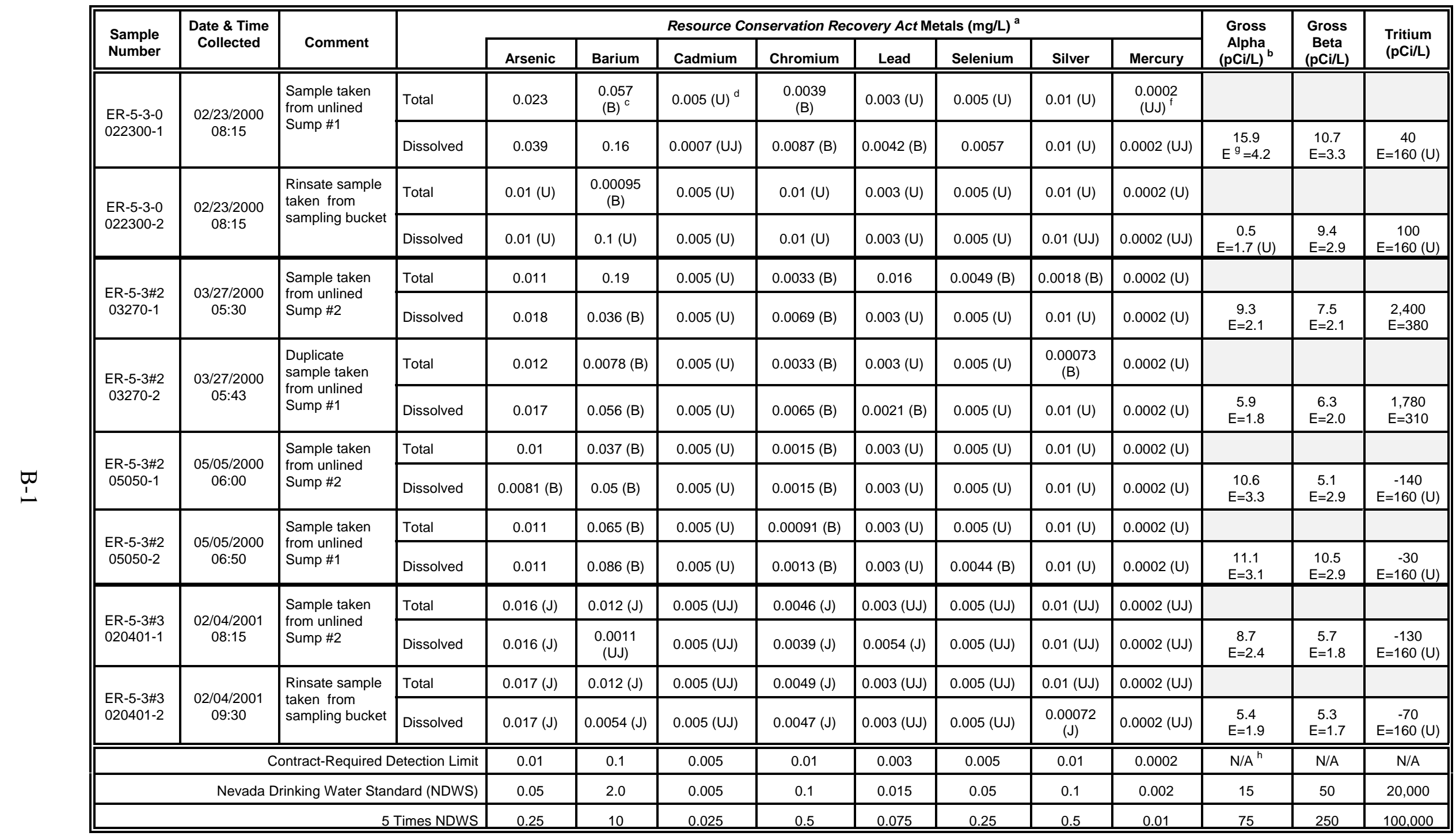

All analyses by Paragon Analytics, Inc. 


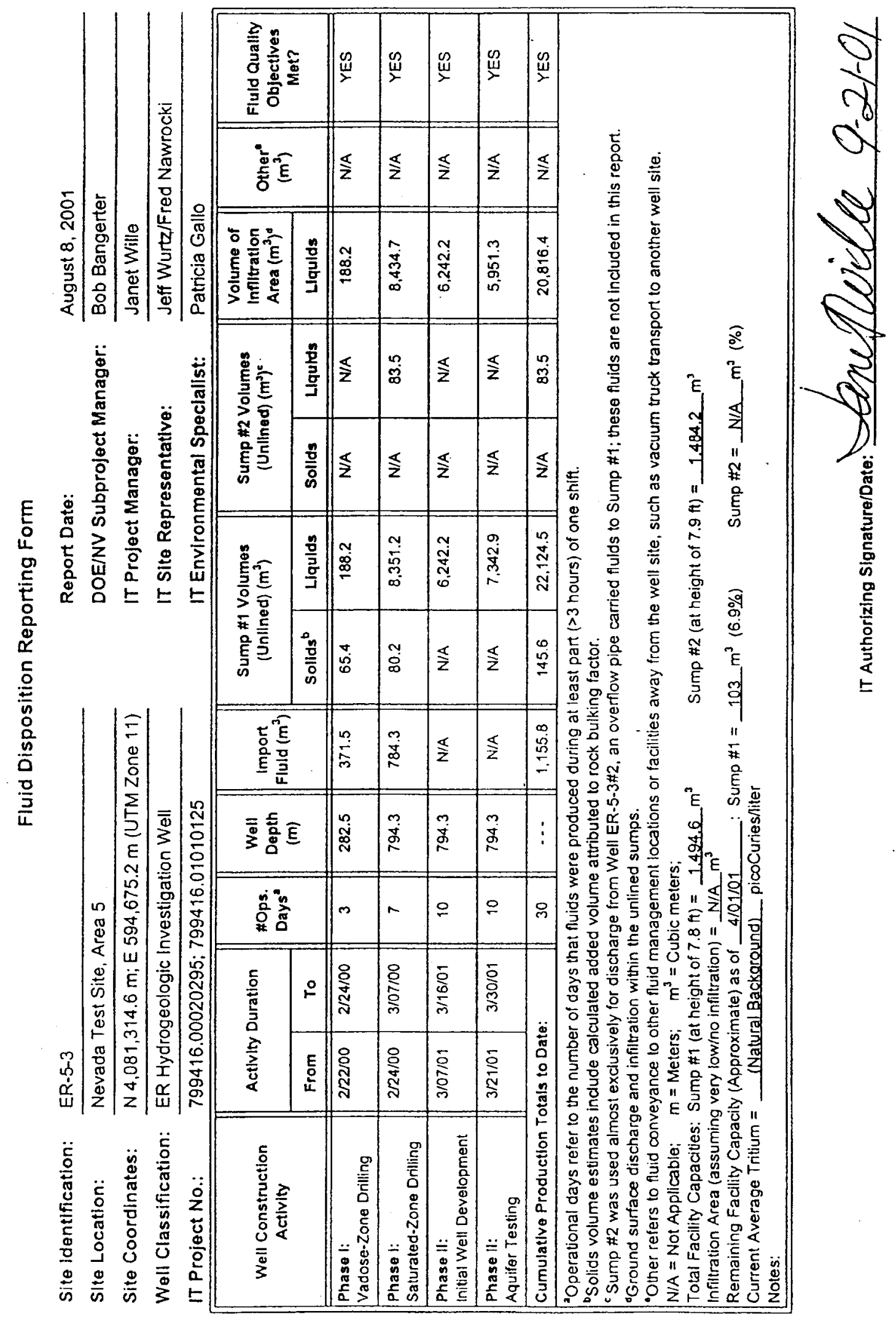




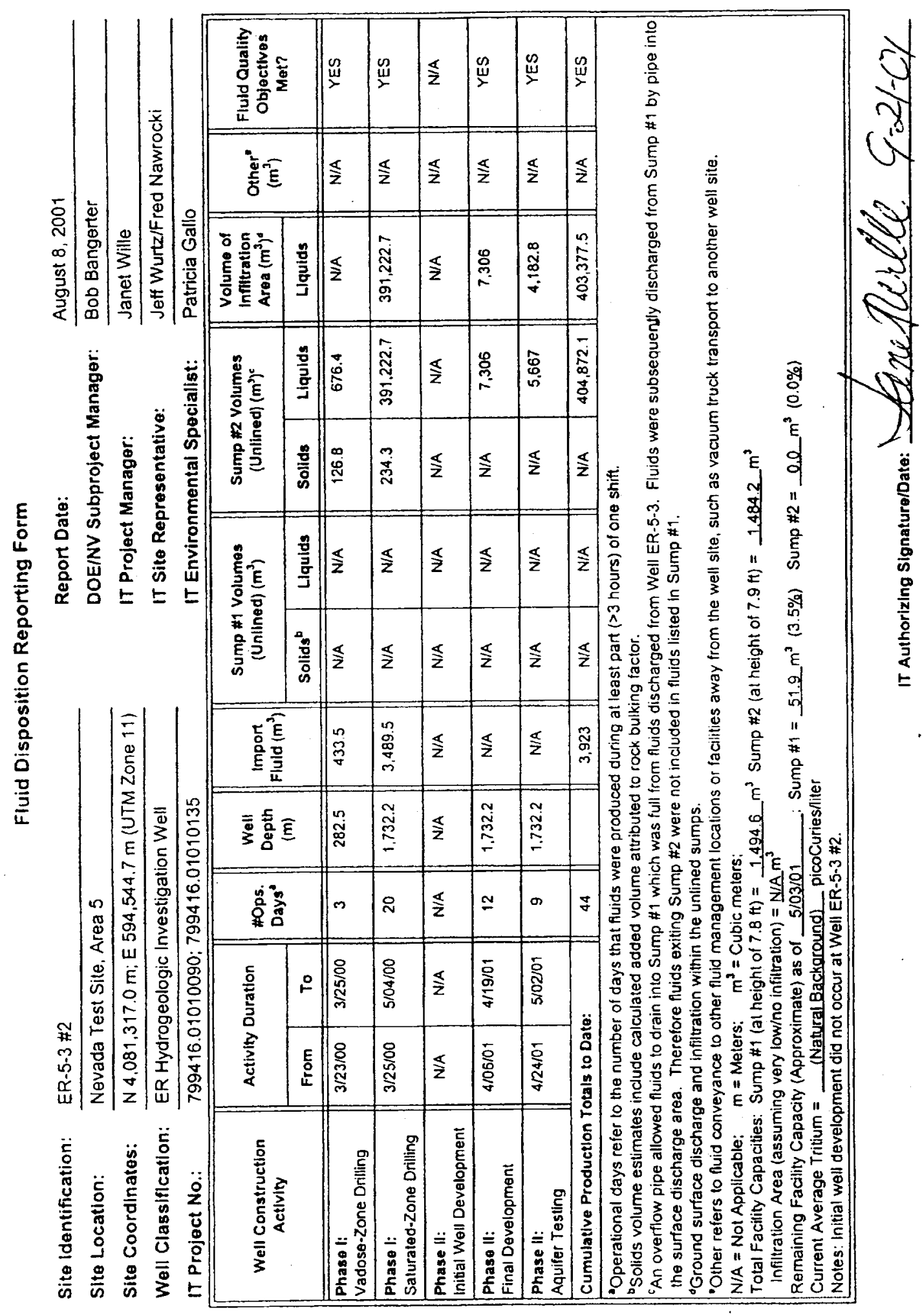




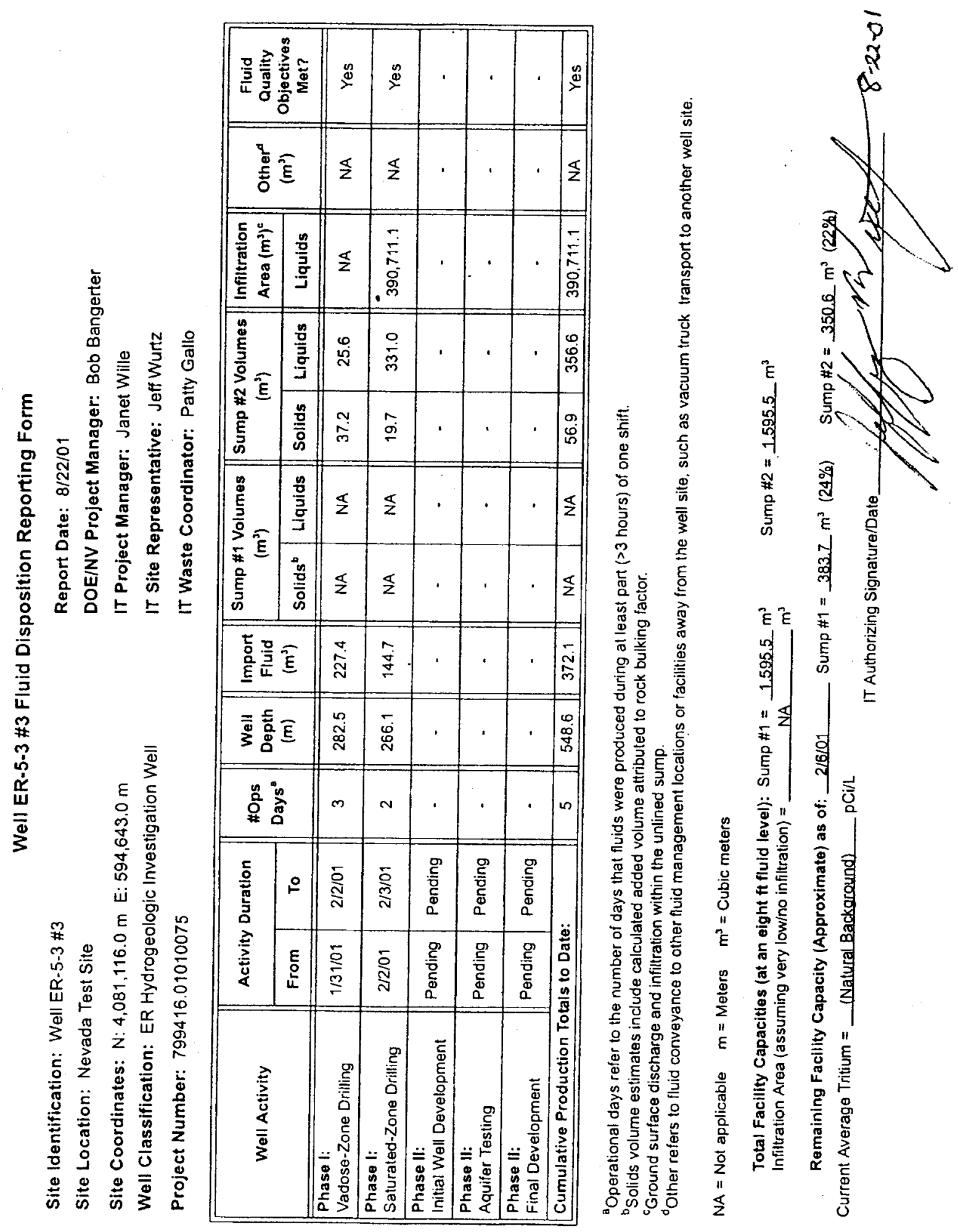




\section{Appendix C \\ Detailed Lithologic Logs for Well Cluster ER-5-3}

C-1 Detailed Lithologic Log for Well ER-5-3

C-2 Detailed Lithologic Log for Well ER-5-3\#2

C-3 Detailed Lithologic Log for Well ER-5-3\#3 


\section{Appendix C-1 \\ Detailed Lithologic Log for Well ER-5-3}


Detailed Lithologic Log for Well ER-5-3

Logged by Heather Huckins-Gang, Bechtel Nevada

February 26, 2001

\begin{tabular}{|c|c|c|c|c|c|}
\hline $\begin{array}{l}\text { Depth } \\
\text { Interval } \\
\text { meters } \\
\text { (feet) } \\
\end{array}$ & $\begin{array}{c}\text { Thickness } \\
\text { meters } \\
\text { (feet) }\end{array}$ & $\begin{array}{c}\text { Sample } \\
\text { Type }^{1}\end{array}$ & $\begin{array}{l}\text { Laboratory } \\
\text { Analyses }^{2}\end{array}$ & Lithologic Description $^{3}$ & $\underset{\text { Unit }}{\text { Stratigraphic }}$ \\
\hline $\begin{array}{l}0-179.8 \\
(0-590)\end{array}$ & $\begin{array}{l}179.8 \\
(590)\end{array}$ & $\begin{array}{c}\text { No } \\
\text { samples } \\
0 \text { to } \\
30.5 \mathrm{~m} \\
(100 \mathrm{ft}) \\
\text { DB1, SC }\end{array}$ & XRD & $\begin{array}{l}\text { Alluvium: Gravelly sand and sandy gravel; matrix of alluvium is not } \\
\text { represented in washed cuttings. Sidewall cores show a poorly sorted, } \\
\text { poorly indurated gravelly sand. Matrix is tuffaceous, moderate yellowish } \\
\text { brown (10YR5/4), moderately to highly calcareous, medium to very fine silty } \\
\text { sand. X-ray diffraction data indicate that this tuffaceous matrix is vitric. } \\
\text { Gravel clasts are almost entirely tuff. Less than } 5 \text { percent limestone and } \\
\text { quartzite clasts. Very rare basalt clasts. Thin, discontinuous carbonate } \\
\text { coats are typically seen on up to } 50 \text { percent of clasts. Coated (i.e. } \\
\text { unbroken) clasts are usually subangular to subrounded fine pebbles. }\end{array}$ & \multirow{2}{*}{$\begin{array}{l}\text { Quaternary or } \\
\text { Tertiary } \\
\text { alluvium }\end{array}$} \\
\hline $\begin{array}{c}179.8-275.2 \\
(590-903)\end{array}$ & $\begin{array}{l}95.4 \\
(313)\end{array}$ & $\begin{array}{l}\text { DA, DB1, } \\
\text { SC }\end{array}$ & $\begin{array}{c}\text { TS, XRD } \\
\text { XRF, } \\
\mathrm{Fe}^{2+} / \mathrm{Fe}^{3+}\end{array}$ & $\begin{array}{l}\text { Alluvium: Gravelly sand and sandy gravel; moderately indurated. Pale } \\
\text { yellowish brown (10YR6/2) to moderate yellowish brown (10YR 5/4), } \\
\text { moderately to highly calcareous, zeolitized, tuffaceous, sandy matrix is } \\
\text { conspicuous in cuttings as fragments and thick coatings on clasts. X-ray } \\
\text { diffraction data indicate opaline silica and argillic alteration of tuffaceous } \\
\text { matrix in some samples. Gravel clasts are predominantly very light gray } \\
\text { and grayish red tuff. Below } 204.2 \mathrm{~m}(670 \mathrm{ft}) \text {, abrupt increase in basalt } \\
\text { clasts and gradual increase in quartzite clasts. Clayey, highly calcareous } \\
\text { sand in sidewall core at } 247.5 \mathrm{~m} \text { ( } 812 \mathrm{ft}) \text {. }\end{array}$ & \\
\hline $\begin{array}{c}275.2-284.4 \\
(903-931)\end{array}$ & $\begin{array}{l}8.5 \\
(28)\end{array}$ & DA, SC & TS, XRD & $\begin{array}{l}\text { Basalt: Grayish black (N2), well indurated, porphyritic with finely crystalline } \\
\text { groundmass of clinopyroxene and plagioclase. Conspicuous olivine, mostly } \\
\text { altered to moderate reddish brown (10R4/6) iddingsite. Conspicuous small } \\
(<2 \mathrm{~mm}) \text { vesicles filled with smectite. Calcified and brownish black } \\
\text { (5YR2/1) to brownish gray (5YR4/1) near base. }\end{array}$ & $\begin{array}{l}\text { Basalt of } \\
\text { Frenchman } \\
\text { Flat }\end{array}$ \\
\hline
\end{tabular}




\begin{tabular}{|c|c|c|c|c|c|}
\hline $\begin{array}{c}\text { Depth } \\
\text { Interval } \\
\text { meters } \\
\text { (feet) } \\
\end{array}$ & $\begin{array}{l}\text { Thickness } \\
\text { meters } \\
\text { (feet) }\end{array}$ & $\begin{array}{c}\text { Sample } \\
\text { Type }^{1}\end{array}$ & $\begin{array}{l}\text { Laboratory } \\
\text { Analyses }^{2}\end{array}$ & Lithologic Description $^{3}$ & $\underset{\text { Unit }}{\text { Stratigraphic }}$ \\
\hline $\begin{array}{l}284.4-507.5 \\
(933-1,665)\end{array}$ & $\begin{array}{l}223.1 \\
(732)\end{array}$ & DA, SC & $\begin{array}{c}\text { TS , XRD } \\
\text { XRF, } \\
\mathrm{Fe}^{2+} / \mathrm{Fe}^{3+}\end{array}$ & $\begin{array}{l}\text { Alluvium: Gravelly sand, sand, and gravelly, clayey sand; poorly to } \\
\text { moderately sorted; moderately indurated. Moderate yellowish brown (10YR } \\
5 / 4 \text { ) to dark brown (10YR 4/2), tuffaceous, sandy matrix. Matrix mostly } \\
\text { zeolitized, and typically moderately calcareous, but varies from non- } \\
\text { calcareous to highly calcareous; highly calcareous below } 496.8 \mathrm{~m}(1,630 \mathrm{ft}) \text {. } \\
\text { Matrix is light brown (5YR5/6) with quartzo-feldspathic alteration in upper } \\
1.5 \mathrm{~m} \text { ( } 5 \mathrm{ft} \text { ), probably due to contact with the overlying basalt flow. Gravel } \\
\text { clasts are approximately equal parts volcanic and Paleozoic clasts at top of } \\
\text { interval, but quartzite percentages increase with depth to a high of } \\
\text { approximately } 80 \text { percent at } 426.7-429.8 \mathrm{~m} \text { (1,400 - 1,410 ft), after which } \\
\text { they decrease again, though quartzite remains predominant. Lesser chert } \\
\text { and rare limestone. Between } 426.7 \text { and } 428.5 \mathrm{~m} \text { (1,400 and } 1,406 \mathrm{ft}) \text {, and } \\
\text { intermittently below } 475.5 \mathrm{~m} \text { (1,560 ft), beds and/or matrix of poorly } \\
\text { indurated, highly calcareous, clayey sand to sandy clay are indicated by } \\
\text { cuttings fragments that effervesce violently and slake readily in hydrochloric } \\
\text { acid, and also slake readily in water, and by large washouts on caliper logs. }\end{array}$ & $\begin{array}{l}\text { Pliocene } \\
\text { through } \\
\text { Miocene } \\
\text { alluvium }\end{array}$ \\
\hline $\begin{array}{c}507.5-512.7 \\
(1,665-1,682)\end{array}$ & $\begin{array}{l}5.2 \\
(17)\end{array}$ & $\begin{array}{l}\mathrm{DB} 2 / \mathrm{DA} \\
\mathrm{SC}\end{array}$ & $\begin{array}{c}\mathrm{TS}, \mathrm{XRD} \\
\text { XRF, } \\
\mathrm{Fe}^{2+} / \mathrm{Fe}^{3+}\end{array}$ & $\begin{array}{l}\text { Bedded Tuff: Probably mostly ash-fall tuff with lesser reworked tuff. } \\
\text { Grayish orange (10YR7/4) to pale yellowish brown (10YR6/2); slightly to } \\
\text { moderately calcareous; poorly indurated. Rare to common white and } \\
\text { grayish orange pink (10R8/2), subangular to angular, devitrified pumice. } \\
\text { Minor to abundant felsic phenocrysts and minor to common mafic minerals, } \\
\text { including rare clinopyroxene. Sand-sized lithic fragments minor in most } \\
\text { beds, occasionally abundant. Some beds, especially near base, have } \\
\text { conspicuous smokey brown to clear cuspate glass shards. Less common } \\
\text { beds are moderate yellowish brown (10YR5/4) to light brown (5YR5/6), } \\
\text { argillic with varying amounts of felsic phenocrysts and angular pumice, } \\
\text { minor mafic minerals, and rare lithic fragments. Sidewall core at } 510.2 \mathrm{~m} \\
\text { (1,674 ft) is pale yellowish brown (10YR6/2), slightly calcareous ash with } \\
\text { minor small, rounded, pink and white sand-sized pumice, rare small felsic } \\
\text { phenocrysts, rare small black and bronze biotite, minor sand-sized lithic } \\
\text { fragments, and conspicuous cuspate glass shards. Tuff is poorly } \\
\text { represented in cuttings; abundant contamination from units up-hole. }\end{array}$ & $\begin{array}{c}\text { Unidentified } \\
\text { ash-fall tuff } \\
\text { within Tertiary } \\
\text { alluvium }\end{array}$ \\
\hline
\end{tabular}




\begin{tabular}{|c|c|c|c|c|c|}
\hline $\begin{array}{l}\text { Depth } \\
\text { Interval } \\
\text { meters } \\
\text { (feet) }\end{array}$ & $\begin{array}{l}\text { Thickness } \\
\text { meters } \\
\text { (feet) }\end{array}$ & $\begin{array}{c}\text { Sample } \\
\text { Type }^{1}\end{array}$ & $\begin{array}{l}\text { Laboratory } \\
\text { Analyses }^{2}\end{array}$ & Lithologic Description ${ }^{3}$ & $\underset{\text { Unit }}{\text { Stratigraphic }}$ \\
\hline $\begin{array}{c}512.7-622.4 \\
(1,682-2,042)\end{array}$ & $109.7(360)$ & DA, SC & $\begin{array}{c}\mathrm{TS}, \mathrm{XRD} \\
\mathrm{XRF} \\
\mathrm{Fe}^{2+} / \mathrm{Fe}^{3+}\end{array}$ & $\begin{array}{l}\text { Alluvium: Gravelly sand, clayey sand, and clay. Sandy matrix is pale } \\
\text { yellowish brown (10YR6/2), moderately indurated, tuffaceous, zeolitic, } \\
\text { slightly to highly calcareous. X-ray diffraction data show opaline silica in } \\
\text { some samples. Pumice content of sand increases with depth, becoming } \\
\text { very abundant near base. Gravel clasts predominantly quartzite with } \\
\text { significant percentages of volcanic rocks and lesser chert and limestone. } \\
\text { Volcanic rocks become more abundant with depth. Possible thin ash beds } \\
\text { intercalated with alluvium at } 521.2 \text { to } 527.3 \mathrm{~m}(1,710 \text { to } 1,730 \mathrm{ft}) \text { and } 548.6 \\
\text { to } 554.7 \mathrm{~m}(1,800 \text { to } 1,820 \mathrm{ft}) \text {. Thin layers of clay and clayey sand noted } \\
\text { between } 536.4 \text { and } 539.5 \mathrm{~m}(1,760 \text { and } 1,770 \mathrm{ft}) \text {. }\end{array}$ & $\begin{array}{l}\text { Pliocene } \\
\text { through } \\
\text { Miocene } \\
\text { alluvium }\end{array}$ \\
\hline $\begin{array}{c}622.4-649.2 \\
(2,042-2,130)\end{array}$ & $\begin{array}{l}26.8 \\
(88)\end{array}$ & DA, SC & $\begin{array}{c}\text { TS, XRD } \\
\text { XRF, } \\
\mathrm{Fe}^{2+} / \mathrm{Fe}^{3+}\end{array}$ & $\begin{array}{l}\text { Moderately Welded Ash-Flow Tuff: Approaches densely welded from } \\
627.3 \text { to } 637.0 \mathrm{~m} \text { ( } 2,058 \text { to } 2,090 \mathrm{ft}) \text {; pale brown }(5 \mathrm{YR} 5 / 2) \text {, devitrified. Minor } \\
\text { pumice, very pale orange (10YR } 8 / 2) \text { up to } 10 \mathrm{~mm} \text { in size, slight vapor } \\
\text { phase mineralization in larger pumice. Minor to common felsic phenocrysts, } \\
\text { including chatoyant sanidine and lesser quartz; common mafic minerals of } \\
\text { black and bronze biotite, and lesser, partially altered clinopyroxene, trace } \\
\text { sphene and hornblende. Rare, small ( }<4 \mathrm{~mm}) \text { volcanic lithic fragments }\end{array}$ & \multirow{3}{*}{$\begin{array}{l}\text { mafic-rich } \\
\text { Ammonia } \\
\text { Tanks Tuff }\end{array}$} \\
\hline $\begin{array}{c}649.2-663.2 \\
(2,130-2,176)\end{array}$ & $\begin{array}{r}14.0 \\
(46)\end{array}$ & DA, SC & None & $\begin{array}{l}\text { Densely Welded Ash-Flow Tuff: Moderate brown (5YR4/4), to grayish red } \\
\text { (10R4/2) near base of interval; devitrified. Minor light brown (5YR5/6) and } \\
\text { white flattened pumice. Very abundant felsic phenocrysts, including quartz; } \\
\text { common bronze biotite, rare to minor clinopyroxene. Lithic fragments rare. }\end{array}$ & \\
\hline $\begin{array}{c}663.2-673.6 \\
(2,176-2,210)\end{array}$ & $\begin{array}{l}10.4 \\
(34)\end{array}$ & DA & None & $\begin{array}{l}\text { Moderately Welded Ash-Flow Tuff: Pale brown (5YR5/2), devitrified. } \\
\text { Rare moderate brown (5YR4/4) pumice. Common felsic phenocrysts, } \\
\text { including quartz and rare chatoyant sanidine; common bronze biotite. } \\
\text { Trace of lithic fragments. }\end{array}$ & \\
\hline
\end{tabular}




\begin{tabular}{|c|c|c|c|c|c|}
\hline $\begin{array}{l}\text { Depth } \\
\text { Interval } \\
\text { meters } \\
\text { (feet) }\end{array}$ & $\begin{array}{l}\text { Thickness } \\
\text { meters } \\
\text { (feet) }\end{array}$ & $\begin{array}{c}\text { Sample } \\
\text { Type }^{1}\end{array}$ & $\begin{array}{l}\text { Laboratory } \\
\text { Analyses }^{2}\end{array}$ & Lithologic Description ${ }^{3}$ & $\underset{\text { Unit }}{\text { Stratigraphic }}$ \\
\hline $\begin{array}{c}673.6-689.5 \\
(2,210-2,262)\end{array}$ & $\begin{array}{l}15.9 \\
(52)\end{array}$ & DA, SC & None & $\begin{array}{l}\text { Moderately Welded Ash-Flow Tuff: Pale yellowish brown (10YR 6/2), } \\
\text { devitrified. Pumice rare to minor, medium light gray (N6), fibrous, with "salt- } \\
\text { and-pepper" look due to weak vapor phase crystallization; also grayish } \\
\text { orange pink (5YR7/2), zeolitized pumice. Minor felsic phenocrysts, } \\
\text { including quartz; minor bronze and black biotite, trace sphene. Rare, small } \\
\text { (<3 mm), angular volcanic lithic fragments, and trace quartzite lithic } \\
\text { fragments. }\end{array}$ & $\begin{array}{l}\text { mafic-rich } \\
\text { Ammonia } \\
\text { Tanks Tuff }\end{array}$ \\
\hline $\begin{array}{c}689.5-702.9 \\
(2,262-2,306)\end{array}$ & $\begin{array}{l}13.4 \\
(44)\end{array}$ & DA, SC & $\begin{array}{c}\mathrm{TS}, \mathrm{XRD} \\
\text { XRF, } \\
\mathrm{Fe}^{2+} / \mathrm{Fe}^{3+}\end{array}$ & $\begin{array}{l}\text { Partially Welded Ash-Flow Tuff: Nonwelded near base; very pale orange } \\
\text { (10YR8/2); zeolitic. Common white pumice, fibrous and vitric to chalky and } \\
\text { zeolitic. Minor felsic phenocrysts including quartz; minor black biotite; rare } \\
\text { sphene and clinopyroxene. Minor sand-sized lithic fragments (volcanic and } \\
\text { quartzite). }\end{array}$ & $\begin{array}{l}\text { mafic-poor } \\
\text { Ammonia } \\
\text { Tanks Tuff }\end{array}$ \\
\hline $\begin{array}{c}702.9-711.4 \\
(2,306-2,334)\end{array}$ & $\begin{array}{l}8.5 \\
(28)\end{array}$ & $\mathrm{DA}, \mathrm{SC}$ & None & $\begin{array}{l}\text { Bedded Tuff: Reworked tuff with lesser ash-fall tuff at base. Reworked tuff } \\
\text { is grayish orange (10YR } 7 / 4) \text { to light brown (5YR5/6) and moderate } \\
\text { yellowish brown (10YR5/4) with "salt-and-pepper" look (due to sand-sized } \\
\text { lithic fragments). Non-calcareous, moderately well indurated (but small } \\
\text { chips slake in water). Common to abundant felsic phenocrysts including } \\
\text { quartz. Very abundant biotite, rare clinopyroxene. Minor white and pink } \\
\text { and rare green small, rounded zeolitized pumice. Very abundant sand- } \\
\text { sized lithic fragments. Ash-fall tuff is very pale orange (10YR8/2) to pale } \\
\text { yellowish brown (10YR 6/2), with common to abundant felsic phenocrysts, } \\
\text { very abundant biotite, rare clinopyroxene and common sand-sized } \\
\text { subrounded to subangular lithic fragments in a matrix of white and lesser } \\
\text { moderate orange pink (5YR8/4) zeolitized pumice. (Angular outlines of } \\
\text { pumice fragments still visible in places). }\end{array}$ & $\begin{array}{l}\text { bedded } \\
\text { Ammonia } \\
\text { Tanks Tuff }\end{array}$ \\
\hline
\end{tabular}




\begin{tabular}{|c|c|c|c|c|c|}
\hline $\begin{array}{l}\text { Depth } \\
\text { Interval } \\
\text { meters } \\
\text { (feet) }\end{array}$ & $\begin{array}{l}\text { Thickness } \\
\text { meters } \\
\text { (feet) }\end{array}$ & $\begin{array}{c}\text { Sample } \\
\text { Type }^{1}\end{array}$ & $\begin{array}{l}\text { Laboratory } \\
\text { Analyses }^{2}\end{array}$ & Lithologic Description ${ }^{3}$ & $\begin{array}{c}\text { Stratigraphic } \\
\text { Unit }\end{array}$ \\
\hline $\begin{array}{l}711.4-722.4 \\
(2,334-2,370)\end{array}$ & $\begin{array}{c}11 \\
(36)\end{array}$ & DA, SC & $\begin{array}{c}\mathrm{TS}, \mathrm{XRD} \\
\text { XRF, } \\
\mathrm{Fe}^{2+} / \mathrm{Fe}^{3+}\end{array}$ & $\begin{array}{l}\text { Nonwelded to Partially Welded Ash-Flow Tuff: Light brown (5YR6/4) to } \\
\text { pale red (10R6/2); zeolitic. Abundant white and light olive gray (5Y6/1) } \\
\text { zeolitized pumice. Minor felsic phenocrysts including quartz and euhedral } \\
\text { feldspar. Common mafic minerals, including rare clinopyroxene. Minor } \\
\text { volcanic lithic fragments up to } 5 \mathrm{~mm} \text {, becoming rare and smaller near base. }\end{array}$ & $\begin{array}{c}\text { mafic-rich } \\
\text { Rainier Mesa } \\
\text { Tuff }\end{array}$ \\
\hline $\begin{array}{c}722.4-765.1 \\
(2,370-2,510)\end{array}$ & $\begin{array}{l}42.7 \\
(140)\end{array}$ & $\mathrm{DA}, \mathrm{SC}$ & None & $\begin{array}{l}\text { Partially Welded to Moderately Welded Ash-Flow Tuff: Light brownish } \\
\text { gray (5YR 6/1) to brownish gray (5YR4/1); devitrified. Minor white to } \\
\text { moderate orange pink (10R7/4) pumice with weak vapor phase } \\
\text { crystallization near top of interval, near bottom minor grayish red pumice } \\
\text { with weak vapor phase. Minor to common felsic phenocrysts, including } \\
\text { euhedral dipyramidal quartz near top, becoming subhedral below. Minor to } \\
\text { common bronze and black biotite, rare pseudomorphs after clinopyroxene. } \\
\text { Rare lithic fragments. Contact between mafic-rich and mafic-poor Rainier } \\
\text { Mesa Tuff is at about } 759.0 \mathrm{~m} \text { (2,490 ft), based on density log. }\end{array}$ & $\begin{array}{l}\text { mafic-rich } \\
\text { Rainier Mesa } \\
\text { Tuff and } \\
\text { mafic-poor } \\
\text { Rainier Mesa } \\
\text { Tuff }\end{array}$ \\
\hline $\begin{array}{c}765.1-771.1 \\
(2,510-2,530)\end{array}$ & $\begin{array}{c}6 \\
(20)\end{array}$ & DA & None & $\begin{array}{l}\text { Moderately Welded to Densely Welded Ash-Flow Tuff: Light brownish } \\
\text { gray (5YR6/1); devitrified, with a few patches of silicification. Minor pale } \\
\text { reddish brown (10R5/4) flattened pumice, and rare fibrous pumice same } \\
\text { color as rock. Common felsic phenocrysts including subhedral quartz; } \\
\text { minor bronze biotite. Rare small quartzite lithic fragments. }\end{array}$ & \multirow{2}{*}{$\begin{array}{c}\text { mafic-poor } \\
\text { Rainier Mesa } \\
\text { Tuff }\end{array}$} \\
\hline $\begin{array}{c}771.1-789.4 \\
(2,530-2,590)\end{array}$ & $\begin{array}{l}18.3 \\
(60)\end{array}$ & DA & None & $\begin{array}{l}\text { Densely Welded Ash-Flow Tuff: Light brown (5YR5/6) with thin bands of } \\
\text { brownish gray (5YR4/1), giving an overall color of moderate brown } \\
\text { (5YR4/4); devitrified. Rare to minor light brown (5YR6/4) devitrified pumice. } \\
\text { Near base, rare dark yellowish brown (10YR4/2) silicified pumice. Common } \\
\text { felsic phenocrysts, mostly feldspar with lesser quartz; rare to minor mafic } \\
\text { minerals mostly biotite. Rare, small lithic fragments. }\end{array}$ & \\
\hline
\end{tabular}




\begin{tabular}{||c|c|c|c|c|c||}
\hline $\begin{array}{c}\text { Depth } \\
\text { Interval } \\
\text { meters } \\
\text { (feet) }\end{array}$ & $\begin{array}{c}\text { Thickness } \\
\text { meters } \\
\text { (feet) }\end{array}$ & $\begin{array}{c}\text { Sample } \\
\text { Type }^{1}\end{array}$ & $\begin{array}{c}\text { Laboratory } \\
\text { Analyses }\end{array}$ & Lithologic Description ${ }^{3}$ & $\begin{array}{c}\text { Stratigraphic } \\
\text { Unit }\end{array}$ \\
\hline \hline $\begin{array}{c}789.4-795.5 \\
(2,590-2,610) \\
\text { TD }\end{array}$ & $\begin{array}{c}6.1 \\
(20)\end{array}$ & DA & None & $\begin{array}{l}\text { Moderately Welded Ash-Flow Tuff: Grayish red (10R4/2) to brownish } \\
\text { gray (5YR4/1); devitrified. Minor pumice, pale reddish brown (10R5/4) to } \\
\text { pale yellowish brown (10YR6/2) with vapor phase crystallization. Minor to } \\
\text { common felsic phenocrysts, feldspar with lesser quartz; minor bronze } \\
\text { biotite. Rare, small lithic fragments. }\end{array}$ & $\begin{array}{c}\text { Rainier Mesa } \\
\text { Tuff }\end{array}$ \\
\hline
\end{tabular}

1. $\mathbf{D A}=$ drill cuttings that represent lithologic character of interval; $\mathbf{D B} 1=$ drill cuttings enriched in hard components; $\mathbf{D B} 2=$ cuttings from interval different than that drilled; $\mathbf{S C}=$ sidewall core.

2 TS $=$ polished thin section $\mathbf{X R D}=\mathrm{x}$-ray diffraction; $\mathbf{X R F}=\mathrm{x}$-ray fluorescence; $\mathbf{F e}^{2+} / \mathrm{Fe}^{3+}=$ wet chemical analysis for iron. See Table $2-3$ of this report for additional information.

3 Descriptions are based mainly on visual examination of lithologic samples using a 10x- to 40x-zoom binocular microscope, and incorporating observations from geophysical logs. Colors describe wet sample color.

Abundances for felsic phenocrysts, pumice fragments, and lithic fragments: trace = only one or two individuals observed; rare = $\leq 1 \%$; $\mathbf{m i n o r}=5 \%$; common $=10 \% ;$ abundant $=15 \%$; very abundant $=\geq 20 \%$.

Abundances for mafic minerals: trace $=$ only one or two individuals observed; rare $=\leq 0.05 \%$; minor $=0.2 \%$; common $=0.5 \%$; abundant $=1 \%$; very abundant $=\geq 2 \%$. 
Appendix C-2

Detailed Lithologic Log for Well ER-5-3\#2 
Detailed Lithologic Log for Well ER-5-3\#2

Logged by Heather Huckins-Gang, Bechtel Nevada

May 22, 2001

\begin{tabular}{|c|c|c|c|c|c|}
\hline $\begin{array}{c}\text { Depth } \\
\text { Interval }^{1} \\
\text { meters } \\
\text { (feet) } \\
\end{array}$ & $\begin{array}{l}\text { Thickness } \\
\text { meters } \\
\text { (feet) }\end{array}$ & $\begin{array}{c}\text { Sample } \\
\text { Type }^{2}\end{array}$ & $\begin{array}{l}\text { Laboratory } \\
\text { Analyses }\end{array}$ & Lithologic Description ${ }^{4}$ & $\underset{\text { Unit }}{\text { Stratigraphic }}$ \\
\hline $\begin{array}{l}0-179.8 \\
(0-590)\end{array}$ & $\begin{array}{l}179.8 \\
(590)\end{array}$ & $\begin{array}{l}\text { DB1 } \\
\text { No } \\
\text { samples } \\
0 \text { to } \\
39.6 \mathrm{~m} \\
(130 \mathrm{ft})\end{array}$ & None & $\begin{array}{l}\text { Alluvium: Gravelly sand and sandy gravel. Unconsolidated to } \\
\text { poorly indurated. Matrix of alluvium is not represented in washed } \\
\text { cuttings, except as thick coatings on clasts and rare pieces seen near } \\
\text { base of interval, where it is moderate yellowish brown (10YR5/4), } \\
\text { moderately to highly calcareous, medium to very fine silty sand. } \\
\text { X-ray diffraction data from corresponding interval in Well ER-5-3 } \\
\text { indicate tuffaceous material in matrix is vitric. Gravel clasts are } \\
\text { almost entirely tuff. Less than } 5 \text { percent limestone and quartzite } \\
\text { clasts. Very rare basalt clasts. Thin, discontinuous carbonate coats } \\
\text { are typically seen on up to } 50 \text { percent of clasts. Coated (i.e. } \\
\text { unbroken) clasts are usually subangular to subrounded fine pebbles. }\end{array}$ & \multirow{2}{*}{$\begin{array}{c}\text { Quaternary or } \\
\text { Tertiary } \\
\text { alluvium }\end{array}$} \\
\hline $\begin{array}{c}179.8-277.4 \\
(590-910)\end{array}$ & $\begin{array}{l}97.5 \\
(320)\end{array}$ & DA/DB1 & $\begin{array}{c}\mathrm{TS}, \mathrm{XRD} \\
\quad \mathrm{XRF} \\
\mathrm{Fe}^{2+} / \mathrm{Fe}^{3+}\end{array}$ & $\begin{array}{l}\text { Alluvium: Gravelly sand and sandy gravel. Pale yellowish brown } \\
\text { (10YR6/2) to moderate yellowish brown (10YR 5/4), poorly to } \\
\text { moderately indurated; moderately to highly calcareous. Zeolitized, } \\
\text { tuffaceous, sandy matrix conspicuous in cuttings as fragments and } \\
\text { thick coatings on clasts. X-ray diffraction data from the corresponding } \\
\text { interval in Well ER-5-3 indicate opaline silica and argillic alteration in } \\
\text { some places. Larger clasts are predominantly very light gray and } \\
\text { grayish red tuff. Below } 213.4 \mathrm{~m} \text { ( } 700 \mathrm{ft}) \text {, abrupt increase in basalt } \\
\text { clasts and gradual increase in quartzite clasts. }\end{array}$ & \\
\hline $\begin{array}{c}277.4-286.5 \\
(910-940)\end{array}$ & $\begin{array}{c}9.1 \\
(30)\end{array}$ & DA & None & $\begin{array}{l}\text { Basalt: Grayish black (N2), well indurated, porphyritic with finely } \\
\text { crystalline groundmass of clinopyroxene and plagioclase. } \\
\text { Conspicuous olivine, mostly altered to moderate reddish brown } \\
\text { (10R4/6) iddingsite; lesser unaltered black olivine. Conspicuous } \\
\text { small }(<2 \mathrm{~mm} \text { ) vesicles filled with smectite. Altered and calcified to } \\
\text { brownish black (5YR2/1) to brownish gray (5YR4/1) near base. }\end{array}$ & $\begin{array}{l}\text { Basalt of } \\
\text { Frenchman } \\
\text { Flat }\end{array}$ \\
\hline
\end{tabular}




\begin{tabular}{|c|c|c|c|c|c|}
\hline $\begin{array}{c}\text { Depth } \\
\text { Interval }^{1} \\
\text { meters }^{-} \\
\text {(feet) }\end{array}$ & $\begin{array}{l}\text { Thickness } \\
\text { meters } \\
\text { (feet) }\end{array}$ & $\begin{array}{c}\text { Sample } \\
\text { Type }^{2}\end{array}$ & $\begin{array}{l}\text { Laboratory } \\
\text { Analyses }^{3}\end{array}$ & Lithologic Description ${ }^{4}$ & $\underset{\text { Unit }}{\text { Stratigraphic }}$ \\
\hline $\begin{array}{l}286.5-512.1 \\
(940-1,680)\end{array}$ & $\begin{array}{l}225.6 \\
(740)\end{array}$ & DA & None & 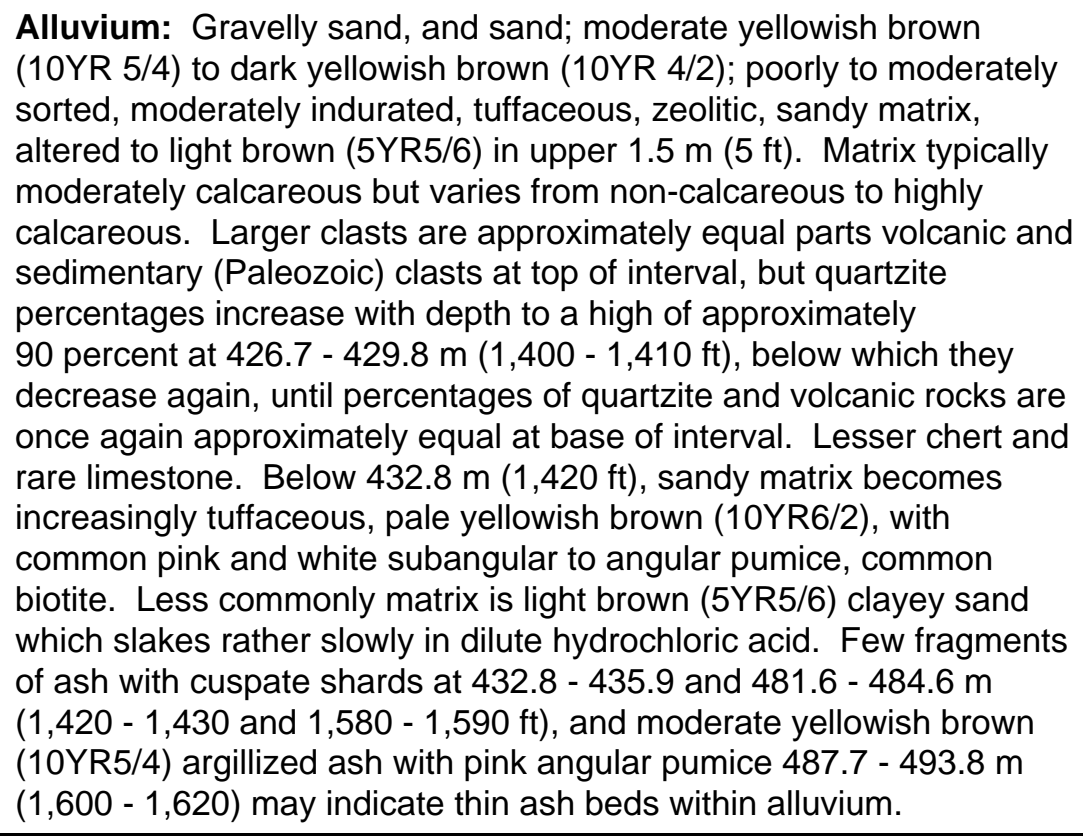 & $\begin{array}{l}\text { Pliocene } \\
\text { through } \\
\text { Miocene } \\
\text { alluvium }\end{array}$ \\
\hline $\begin{array}{c}512.1-516.6 \\
(1,680-1,695)\end{array}$ & $\begin{array}{c}4.6 \\
(15)\end{array}$ & DA/DB2 & None & $\begin{array}{l}\text { Bedded Tuff: Pale yellowish brown (10YR6/2) with lesser moderate } \\
\text { reddish orange (10R6/6) interbeds; moderately indurated, slightly } \\
\text { calcareous. Minor white and pink, fibrous, vitric, subrounded to } \\
\text { subangular pumice. Minor felsic phenocrysts; rare to minor biotite. } \\
\text { Minor sand-sized lithic fragments. Abundant smoky brown cuspate } \\
\text { glass shards. Poorly represented in cuttings. }\end{array}$ & $\begin{array}{l}\text { Unidentified } \\
\text { ash-fall tuff } \\
\text { within Tertiary } \\
\text { alluvium }\end{array}$ \\
\hline
\end{tabular}




\begin{tabular}{|c|c|c|c|c|c|}
\hline $\begin{array}{l}\text { Depth } \\
\text { Interval }^{1} \\
\text { meters } \\
\text { (feet) }\end{array}$ & $\begin{array}{c}\text { Thickness } \\
\text { meters } \\
\text { (feet) }\end{array}$ & $\begin{array}{c}\text { Sample } \\
\text { Type }^{2}\end{array}$ & $\begin{array}{l}\text { Laboratory } \\
\text { Analyses }^{3}\end{array}$ & Lithologic Description ${ }^{4}$ & $\underset{\text { Unit }}{\text { Stratigraphic }}$ \\
\hline $\begin{array}{c}516.6-591.3 \\
(1,695-2,060)\end{array}$ & $\begin{array}{l}111.3 \\
(365)\end{array}$ & DA & None & $\begin{array}{l}\text { Alluvium: Gravelly sand. Pale yellowish brown (10YR } 6 / 2) \text { to } \\
\text { moderate yellowish brown (10YR 4/2); moderately calcareous, } \\
\text { moderately indurated; sorted and bedded in places. Sandy matrix is } \\
\text { highly tuffaceous, zeolitic. Gravel clasts comprise approximately } \\
\text { equal percentages of volcanic rocks and Paleozoic sedimentary rocks } \\
\text { throughout most of interval. Volcanic rocks predominate below about } \\
591.3 \mathrm{~m}(1,940 \mathrm{ft}) \text {. Evidence of thin ash beds at } 521.2-524.3 \mathrm{~m} \\
(1,710-1,720 \mathrm{ft}) \text { (cuspate shards), } 530.4-533.4 \mathrm{~m}(1,740-1,750 \mathrm{ft}) \\
\text { (fine grained ash), } 551.7-554.7 \mathrm{~m}(1,810-1,820 \mathrm{ft}) \text { (fine grained and } \\
\text { light brown ash) and } 557.8-560.8 \mathrm{~m}(1,830-1,840 \mathrm{ft} \text { ) (light brown, } \\
\text { argillic). }\end{array}$ & $\begin{array}{l}\text { Pliocene } \\
\text { through } \\
\text { Miocene } \\
\text { alluvium }\end{array}$ \\
\hline $\begin{array}{c}627.9-652.3 \\
(2,060-2,140)\end{array}$ & $\begin{array}{l}24.4 \\
(80)\end{array}$ & DA & None & $\begin{array}{l}\text { Moderately welded Ash-Flow Tuff: Pale brown (5YR 5/2); } \\
\text { devitrified. Minor very pale orange (10YR8/2) pumice, devitrified with } \\
\text { weak vapor phase crystallization. Common felsic phenocrysts, } \\
\text { including quartz, chatoyant sanidine; common mafic minerals, } \\
\text { including clinopyroxene, mostly bronze biotite. Rare lithic fragments. }\end{array}$ & \multirow{3}{*}{$\begin{array}{l}\text { mafic-rich } \\
\text { Ammonia } \\
\text { Tanks Tuff }\end{array}$} \\
\hline $\begin{array}{l}652.3-667.5 \\
(2,140-2,190)\end{array}$ & $\begin{array}{l}15.2 \\
(50)\end{array}$ & DA & None & $\begin{array}{l}\text { Densely welded Ash-Flow Tuff: Moderate brown (5YR4/4) to } \\
\text { grayish red (10R4/2) below; devitrified with weak vapor phase } \\
\text { crystallization. Minor whitish pumice. Very abundant felsic } \\
\text { phenocrysts including quartz, chatoyant sanidine; common mafic } \\
\text { minerals, including trace clinopyroxene. No lithic fragments seen in } \\
\text { samples. }\end{array}$ & \\
\hline $\begin{array}{c}667.5-691.9 \\
(2,190-2,270)\end{array}$ & $\begin{array}{l}24.4 \\
(80)\end{array}$ & DA & None & $\begin{array}{l}\text { Moderately Welded Ash-Flow Tuff: Pale brown (5YR5/2); } \\
\text { devitrified. Minor very pale orange (10YR8/2), devitrified pumice. } \\
\text { Common felsic phenocrysts, including chatoyant sanidine and quartz; } \\
\text { minor mafic minerals, including bronze biotite and rare clinopyroxene. } \\
\text { No lithic fragments seen in samples. }\end{array}$ & \\
\hline
\end{tabular}




\begin{tabular}{|c|c|c|c|c|c|}
\hline $\begin{array}{c}\text { Depth } \\
\text { Interval }^{1} \\
\text { meters } \\
\text { (feet) }\end{array}$ & $\begin{array}{l}\text { Thickness } \\
\text { meters } \\
\text { (feet) }\end{array}$ & $\begin{array}{c}\text { Sample } \\
\text { Type }^{2}\end{array}$ & $\begin{array}{l}\text { Laboratory } \\
\text { Analyses }^{3}\end{array}$ & Lithologic Description ${ }^{4}$ & $\underset{\text { Unit }}{\text { Stratigraphic }}$ \\
\hline $\begin{array}{c}691.9-704.1 \\
(2,270-2,310)\end{array}$ & $\begin{array}{l}12.2 \\
(40)\end{array}$ & DA & None & $\begin{array}{l}\text { Partially Welded Ash-flow Tuff: Pale yellowish brown (10YR6/2) to } \\
\text { very pale orange (10YR8/2); zeolitized. Minor dusky yellowish brown } \\
\text { (10YR4/2) vitric pumice near top; pumice medium gray (N5) with } \\
\text { vapor phase crystallization near base; Common felsic phenocrysts, } \\
\text { including chatoyant sanidine, quartz; common mafic minerals, } \\
\text { including rare clinopyroxene, trace sphene. Rare volcanic lithic } \\
\text { fragments. }\end{array}$ & $\begin{array}{l}\text { mafic-poor } \\
\text { Ammonia } \\
\text { Tanks Tuff }\end{array}$ \\
\hline $\begin{array}{l}704.1-713.2 \\
2,310-2,340\end{array}$ & $\begin{array}{c}9.1 \\
(30)\end{array}$ & DA & None & $\begin{array}{l}\text { Bedded Tuff: Reworked tuff with lesser ash-fall tuff at base. } \\
\text { Reworked tuff is grayish orange (10YR 7/4) to light brown (5YR5/6), } \\
\text { and moderate yellowish brown (10YR5/4) sometimes with "salt-and- } \\
\text { pepper" look (due to sand-sized lithic fragments); non-calcareous, } \\
\text { moderately well indurated. Minor white and pink and rare green } \\
\text { small, rounded zeolitized pumice. Common to abundant felsic } \\
\text { phenocrysts including quartz; abundant biotite, rare clinopyroxene. } \\
\text { Localized concentrations of sand-sized lithic fragments. Ash-fall tuff } \\
\text { is very pale orange (10YR8/2) to pale yellowish brown (10YR 6/2) } \\
\text { with common to abundant felsic phenocrysts, very abundant biotite, } \\
\text { rare clinopyroxene, and common sand-sized subrounded to } \\
\text { subangular lithic fragments in a matrix of white and lesser moderate } \\
\text { orange pink (5YR8/4) zeolitized pumice. Angular outlines of pumice } \\
\text { fragments still visible in places. }\end{array}$ & $\begin{array}{c}\text { bedded } \\
\text { Ammonia } \\
\text { Tanks Tuff }\end{array}$ \\
\hline $\begin{array}{c}713.2-722.4 \\
(2,340-2,370)\end{array}$ & $\begin{array}{c}9.1 \\
(30)\end{array}$ & DA & None & $\begin{array}{l}\text { Nonwelded to Partially Welded Ash-flow Tuff: Light brown } \\
\text { ( } 5 \text { YR6/4) (looks pink dry) to pale red (10R6/2) below about } 713.2 \mathrm{~m} \\
\text { ( } 2,340 \mathrm{ft}) \text {; zeolitic. Abundant white and light olive gray (5Y6/1), } \\
\text { zeolitized pumice. Minor felsic phenocrysts including quartz and } \\
\text { euhedral feldspar; common mafic minerals, including rare } \\
\text { clinopyroxene. Minor volcanic lithic fragments up to } 5 \mathrm{~mm} \text {, becoming } \\
\text { rare and smaller near base. }\end{array}$ & $\begin{array}{c}\text { mafic-rich } \\
\text { Rainier Mesa } \\
\text { Tuff }\end{array}$ \\
\hline
\end{tabular}




\begin{tabular}{|c|c|c|c|c|c|}
\hline $\begin{array}{c}\text { Depth } \\
\text { Interval }^{1} \\
\text { meters }^{2} \\
\text { (feet) }\end{array}$ & $\begin{array}{l}\text { Thickness } \\
\text { meters } \\
\text { (feet) }\end{array}$ & $\begin{array}{c}\text { Sample } \\
\text { Type }^{2}\end{array}$ & $\begin{array}{l}\text { Laboratory } \\
\text { Analyses }^{3}\end{array}$ & Lithologic Description ${ }^{4}$ & $\underset{\text { Unit }}{\text { Stratigraphic }}$ \\
\hline $\begin{array}{c}722.4-768.1 \\
(2,370-2,520)\end{array}$ & $\begin{array}{l}45.7 \\
(150)\end{array}$ & DA & None & $\begin{array}{l}\text { Partially Welded to Moderately Welded Ash-Flow Tuff: Light } \\
\text { brownish gray (5YR 6/1) to brownish gray (5YR4/1); devitrified. } \\
\text { Minor white to moderate orange pink (10R7/4) pumice with weak } \\
\text { vapor phase crystallization near top of interval; minor grayish red } \\
\text { pumice with weak vapor phase crystallization near bottom. Minor to } \\
\text { common felsic phenocrysts, including euhedral dipyramidal quartz } \\
\text { near top, becoming subhedral below; minor to common bronze and } \\
\text { black biotite, rare pseudomorphs after clinopyroxene. Rare lithic } \\
\text { fragments. Contact between mafic-rich and mafic-poor Rainier Mesa } \\
\text { Tuff is at about } 759.0 \mathrm{~m}(2,490 \mathrm{ft}) \text {, based on density log. }\end{array}$ & $\begin{array}{l}\text { mafic-rich } \\
\text { Rainier Mesa } \\
\text { Tuff and } \\
\text { mafic-poor } \\
\text { Rainier Mesa } \\
\text { Tuff }\end{array}$ \\
\hline $\begin{array}{c}768.1-774.2 \\
2,520-2,540)\end{array}$ & $\begin{array}{l}6.1 \\
(20)\end{array}$ & DA & None & $\begin{array}{l}\text { Moderately to Densely Welded Ash-Flow Tuff: Light brownish gray } \\
\text { (5YR6/1); devitrified, with a few patches of silicification. Minor pale } \\
\text { reddish brown (10R5/4), flattened pumice, and rare fibrous pumice } \\
\text { same color as rock. Common felsic phenocrysts including subhedral } \\
\text { quartz; minor bronze biotite. Rare small quartzite lithic fragments. }\end{array}$ & \multirow{3}{*}{$\begin{array}{c}\text { mafic-poor } \\
\text { Rainier Mesa } \\
\text { Tuff }\end{array}$} \\
\hline $\begin{array}{c}774.2-792.5 \\
(2,540-2,600)\end{array}$ & $\begin{array}{l}18.3 \\
(60)\end{array}$ & DA & $\begin{array}{c}\mathrm{TS}, \mathrm{XRD} \\
\text { XRF, } \\
\mathrm{Fe}^{2+} / \mathrm{Fe}^{3+}\end{array}$ & $\begin{array}{l}\text { Densely Welded Ash-Flow Tuff: Light brown (5YR5/6) with lesser } \\
\text { bands of brownish gray (5YR4/1), giving an overall color of moderate } \\
\text { brown (5YR4/4); devitrified. Rare to minor light brown (5YR6/4), } \\
\text { devitrified pumice. Near base, rare dark yellowish brown (10YR4/2) } \\
\text { silicified pumice. Common felsic phenocrysts, mostly feldspar with } \\
\text { lesser quartz; rare to minor mafic minerals, biotite and rare iron-oxide } \\
\text { pseudomorphs after magnetite. Rare, small lithic fragments. }\end{array}$ & \\
\hline $\begin{array}{l}792.5-826.0 \\
(2,600-2,710)\end{array}$ & $\begin{array}{l}33.5 \\
(110)\end{array}$ & DA & None & $\begin{array}{l}\text { Moderately Welded Ash-Flow Tuff: Grayish red (10R4/2) to } \\
\text { brownish gray ( } 5 \text { YR4/1); devitrified. Minor pumice, pale reddish } \\
\text { brown (10R5/4) to pale yellowish brown (10YR6/2) with vapor phase } \\
\text { crystallization. Minor to common felsic phenocrysts, feldspar with } \\
\text { lesser quartz; minor bronze biotite. Rare, small lithic fragments, } \\
\text { becoming minor toward base of interval. }\end{array}$ & \\
\hline
\end{tabular}




\begin{tabular}{|c|c|c|c|c|c|}
\hline $\begin{array}{l}\text { Depth } \\
\text { Interval }^{1} \\
\text { meters } \\
\text { (feet) }\end{array}$ & $\begin{array}{l}\text { Thickness } \\
\text { meters } \\
\text { (feet) }\end{array}$ & $\begin{array}{c}\text { Sample } \\
\text { Type }^{2}\end{array}$ & $\begin{array}{l}\text { Laboratory } \\
\text { Analyses }^{3}\end{array}$ & Lithologic Description ${ }^{4}$ & $\underset{\text { Unit }}{\text { Stratigraphic }}$ \\
\hline $\begin{array}{l}826.0-838.2 \\
2,710-2,750\end{array}$ & $\begin{array}{l}12.2 \\
(40)\end{array}$ & DA & None & $\begin{array}{l}\text { Nonwelded to Partially Welded Ash-Flow Tuff: Pale brown } \\
\text { (5YR5/2); devitrified. Common moderate red (5R5/4) to grayish red } \\
\text { (10R4/2) pumice and smaller pale yellowish orange (10YR8/6), } \\
\text { zeolitic pumice with remnant fibrous structure. Minor to common } \\
\text { felsic phenocrysts of feldspar with lesser quartz; common to minor } \\
\text { biotite. Minor lithic fragments. Basal contact gradational. }\end{array}$ & \multirow{3}{*}{$\begin{array}{c}\text { mafic-poor } \\
\text { Rainier Mesa } \\
\text { Tuff }\end{array}$} \\
\hline $\begin{array}{c}838.2-853.4 \\
(2,750-2,780)\end{array}$ & $\begin{array}{c}9.1 \\
(30)\end{array}$ & DA & None & $\begin{array}{l}\text { Nonwelded Ash-Flow Tuff: Grayish orange pink (10R8/2) to pale } \\
\text { red (10R6/2); devitrified. Altered, and light brown (5YR5/6) in places. } \\
\text { Common white to moderate pink (5R7/4) devitrified pumice with } \\
\text { remnant fibrous structure. Minor felsic phenocrysts including quartz. } \\
\text { Minor mafic minerals, black biotite, and altered dark spots that may } \\
\text { have once been biotite. Minor sand-sized lithic fragments. }\end{array}$ & \\
\hline $\begin{array}{c}853.4-855.6 \\
(2,780-2,807)\end{array}$ & $\begin{array}{l}8.2 \\
(27)\end{array}$ & DA & $\begin{array}{c}\mathrm{TS}, \mathrm{XRD} \\
\mathrm{XRF} \\
\mathrm{Fe}^{2+} / \mathrm{Fe}^{3+}\end{array}$ & $\begin{array}{l}\text { Nonwelded Ash-Flow Tuff: Very pale orange (10YR8/2); zeolitic. } \\
\text { Common light brown ( } 5 \text { YR5/6) and grayish orange pink (5YR7/2) } \\
\text { zeolitized pumice with remnant fibrous structure. Minor to common } \\
\text { felsic phenocrysts, including subhedral quartz; minor biotite. Rare } \\
\text { volcanic lithic fragments. }\end{array}$ & \\
\hline $\begin{array}{l}855.6-872.3 \\
(2,807-2,862)\end{array}$ & $\begin{array}{l}16.8 \\
(55)\end{array}$ & $\begin{array}{c}\text { DA/DB2 } \\
\text { SC }\end{array}$ & $\begin{array}{c}\mathrm{TS}, \mathrm{XRD} \\
\text { XRF, } \\
\mathrm{Fe}^{2+} / \mathrm{Fe}^{3+}\end{array}$ & $\begin{array}{l}\text { Bedded Tuff: Mostly reworked tuff with lesser interbedded ash-fall } \\
\text { tuff. Grayish orange (10YR7/4); zeolitized. Moderately well } \\
\text { indurated, non-calcareous. Common to abundant white and lesser } \\
\text { brown and green small, rounded, zeolitized pumice. Common felsic } \\
\text { phenocrysts, including quartz; common mafic minerals include } \\
\text { hornblende, orthopyroxene, biotite, magnetite, clinopyroxene. Sand- } \\
\text { sized lithic fragments rare in some beds to abundant in others. } \\
\text { Abundant caved material in cuttings. }\end{array}$ & $\begin{array}{c}\text { Tuff of } \\
\text { Holmes Road }\end{array}$ \\
\hline $\begin{array}{l}872.3-881.2 \\
2,862-2,891\end{array}$ & $\begin{array}{l}8.8 \\
(29)\end{array}$ & DA & $\begin{array}{c}\mathrm{TS}, \mathrm{XRD} \\
\text { XRF, } \\
\mathrm{Fe}^{2+} / \mathrm{Fe}^{3+}\end{array}$ & $\begin{array}{l}\text { Densely welded Ash-Flow Tuff: Brownish black (5YR2/1); altered } \\
\text { to light brown (5YR5/6) in places, especially near fractures, vitric } \\
\text { (vitrophyric). Lacks visible pumice. Minor felsic phenocrysts; } \\
\text { common black biotite. Conspicuous fractures healed with finely } \\
\text { crystalline silica. No lithic fragments observed in samples. }\end{array}$ & $\begin{array}{l}\text { mafic-rich } \\
\text { Topopah } \\
\text { Spring Tuff }\end{array}$ \\
\hline
\end{tabular}




\begin{tabular}{|c|c|c|c|c|c|}
\hline $\begin{array}{c}\text { Depth } \\
\text { Interval }^{1} \\
\text { meters } \\
\text { (feet) } \\
\end{array}$ & $\begin{array}{l}\text { Thickness } \\
\text { meters } \\
\text { (feet) }\end{array}$ & $\begin{array}{c}\text { Sample } \\
\text { Type }^{2}\end{array}$ & $\begin{array}{l}\text { Laboratory } \\
\text { Analyses }\end{array}$ & Lithologic Description ${ }^{4}$ & $\underset{\text { Unit }}{\text { Stratigraphic }}$ \\
\hline $\begin{array}{c}881.2-890.0 \\
(2,891-2,920)\end{array}$ & $\begin{array}{l}8.8 \\
(29)\end{array}$ & DA & None & $\begin{array}{l}\text { Moderately to Densely Welded Ash-Flow Tuff: Light brown } \\
\text { (5YR5/6), devitrified, weakly quartzo-feldspathic. Silicified and } \\
\text { moderate brown (5YR4/4), in places, especially near fractures. Rare } \\
\text { grayish brown (5YR3/2) devitrified pumice. Common felsic } \\
\text { phenocrysts; common mafic minerals, including black biotite and } \\
\text { conspicuous clinopyroxene. Conspicuous fractures and small vugs } \\
\text { filled with microcrystalline silica. Rare lithic fragments. }\end{array}$ & \multirow{3}{*}{$\begin{array}{l}\text { mafic-rich } \\
\text { Topopah } \\
\text { Spring Tuff }\end{array}$} \\
\hline $\begin{array}{c}890.0-906.8 \\
(2,920-2,975)\end{array}$ & $\begin{array}{l}12.2 \\
(40)\end{array}$ & DA & $\begin{array}{c}\mathrm{TS}, \mathrm{XRD} \\
\text { XRF, } \\
\mathrm{Fe}^{2+} / \mathrm{Fe}^{3+}\end{array}$ & $\begin{array}{l}\text { Moderately to Densely Welded Ash-Flow Tuff: Moderate brown } \\
\text { (5YR4/4), devitrified. Minor to common pale yellowish brown } \\
\text { (10YR6/2) pumice with vapor phase crystallization. Near base, } \\
\text { pumice becomes larger and vesicular, light brown (5YR5/6), pale red } \\
\text { (5R6/2), and same color as rock. Minor felsic phenocrysts; minor } \\
\text { mafic minerals, including black biotite, clinopyroxene. No lithic } \\
\text { fragments seen. } \\
\text { * Depth of lower contact based on geophysical logs. }\end{array}$ & \\
\hline $\begin{array}{c}906.8-908.3 \\
(2,975-2,980)\end{array}$ & $\begin{array}{c}6.1 \\
(20)\end{array}$ & DA & None & $\begin{array}{l}\text { Partially Welded Ash-Flow Tuff: Light brown (5YR6/6); devitrified, } \\
\text { silicified in places, especially near fractures. Minor moderate red } \\
\text { (5R4/6), zeolitized pumice. Minor felsic phenocrysts; common black } \\
\text { biotite; minor lithic fragments. Inclusions of black glass. } \\
\text { Conspicuous silica-filled fractures. }\end{array}$ & \\
\hline $\begin{array}{c}908.3-914.4 \\
(2,980-3,000)\end{array}$ & $\begin{array}{l}6.1 \\
(20)\end{array}$ & DA & None & $\begin{array}{l}\text { Partially Welded Ash-Flow Tuff: Dark yellowish brown (10YR4/2) } \\
\text { to dusky yellowish brown (10YR2/2); silicified. Common moderate } \\
\text { orange pink (10R7/4) silicified pumice. Minor felsic phenocrysts; } \\
\text { minor mafic minerals of clinopyroxene and biotite. No lithic fragments } \\
\text { observed. Curved glass shards and vesicular fragments in matrix. } \\
\text { Grades into areas of light brown (5YR6/6) tuff similar to above, which } \\
\text { breaks into very thin pieces. }\end{array}$ & $\begin{array}{l}\text { Topopah } \\
\text { Spring Tuff }\end{array}$ \\
\hline
\end{tabular}




\begin{tabular}{|c|c|c|c|c|c|}
\hline $\begin{array}{l}\text { Depth } \\
\text { Interval }^{1} \\
\text { meters } \\
\text { (feet) }\end{array}$ & $\begin{array}{l}\text { Thickness } \\
\text { meters } \\
\text { (feet) }\end{array}$ & $\begin{array}{c}\text { Sample } \\
\text { Type }^{2}\end{array}$ & $\begin{array}{l}\text { Laboratory } \\
\text { Analyses }^{3}\end{array}$ & Lithologic Description ${ }^{4}$ & $\underset{\text { Unit }}{\text { Stratigraphic }}$ \\
\hline $\begin{array}{l}914.4-921.7 \\
(3,000-3,024)\end{array}$ & $\begin{array}{l}7.3 \\
(24)\end{array}$ & DA & None & $\begin{array}{l}\text { Nonwelded Ash-Flow Tuff: Moderate brown (5YR4/4); devitrified. } \\
\text { Minor pale reddish brown, vitric to zeolitic pumice (looks pink dry). } \\
\text { Abundant felsic phenocrysts including quartz; minor mafic minerals, } \\
\text { mainly black biotite. Rare lithic fragments. }\end{array}$ & $\begin{array}{l}\text { Topopah } \\
\text { Spring Tuff }\end{array}$ \\
\hline $\begin{array}{c}921.7-931.2 \\
(3,024-3,055)\end{array}$ & $\begin{array}{c}9.5 \\
(31)\end{array}$ & $\begin{array}{l}\text { DA } \\
\text { SC }\end{array}$ & $\begin{array}{c}\mathrm{TS}, \mathrm{XRD} \\
\mathrm{XRF} \\
\mathrm{Fe}^{2+} / \mathrm{Fe}^{3+}\end{array}$ & $\begin{array}{l}\text { Bedded Tuff: Pale yellowish brown (10YR6/2) to dark yellowish } \\
\text { brown (10YR4/2) and lesser olive gray (5Y4/1) (in sidewall cores); } \\
\text { moderately indurated, zeolitized. Common green and lesser white } \\
\text { and brown sand-sized rounded pumice. Minor felsic phenocrysts; } \\
\text { common to abundant mafic minerals, including black biotite and } \\
\text { orthopyroxene. Rare to minor lithic fragments. } \\
\text { * Petrographic analyses by R. G. Warren indicate the possible } \\
\text { presence of fragments of other stratigraphic units in this interval. }\end{array}$ & $\begin{array}{l}\text { Calico Hills } \\
\text { Formation* }\end{array}$ \\
\hline $\begin{array}{c}931.2-964.4 \\
(3,055-3,164)\end{array}$ & $\begin{array}{c}33.2 \\
(109)\end{array}$ & $\begin{array}{l}\text { DB1, } \\
\text { SC }\end{array}$ & None & $\begin{array}{l}\text { Nonwelded to Partially Welded Ash-Flow Tuff: Light brown } \\
\text { (5YR6/4) to grayish orange pink (5YR7/2); also, in sidewall cores, } \\
\text { pale reddish brown (10R5/4) to moderate yellowish brown (10YR5/4) } \\
\text { near top and pale yellowish brown (10YR6/2) below; zeolitized. Minor } \\
\text { white to pale greenish yellow and grayish orange pink (10R8/2), } \\
\text { zeolitized pumice near top of interval, becoming common to abundant } \\
\text { toward base. Felsic phenocrysts rare, increasing to minor below } \\
947.9 \mathrm{~m} \text { ( } 3,110 \mathrm{ft}) ; \text { very abundant mafic minerals, including black } \\
\text { biotite, lesser orthopyroxene and rare clinopyroxene. Phenocryst-rich } \\
\text { volcanic lithic fragments are apparently abundant in cuttings, rare to } \\
\text { minor in sidewall cores. Contains interbeds, especially between } \\
951.0 \text { and } 960.1 \mathrm{~m} \text { ( } 3,120 \text { and } 3,150 \text { ft), of moderate brown ( } 5 Y R 3 / 4) \\
\text { fine-grained, non-calcareous tuffaceous sandstone. This tuffaceous } \\
\text { sandstone contains rare black (N1) pumice and common, tiny (fine to } \\
\text { medium sand-sized [0.5 mm]) white, rounded zeolitic pumice. Minor } \\
\text { felsic phenocrysts; abundant mafic minerals including orthopyroxene. }\end{array}$ & $\begin{array}{l}\text { Wahmonie } \\
\text { Formation }\end{array}$ \\
\hline
\end{tabular}




\begin{tabular}{|c|c|c|c|c|c|}
\hline $\begin{array}{c}\text { Depth } \\
\text { Interval }^{\mathbf{1}} \\
\text { meters }^{-} \\
\text {(feet) }\end{array}$ & $\begin{array}{l}\text { Thickness } \\
\text { meters } \\
\text { (feet) }\end{array}$ & $\begin{array}{c}\text { Sample } \\
\text { Type }^{2}\end{array}$ & $\begin{array}{l}\text { Laboratory } \\
\text { Analyses }^{3}\end{array}$ & Lithologic Description ${ }^{4}$ & $\underset{\text { Unit }}{\text { Stratigraphic }}$ \\
\hline $\begin{array}{c}964.4-986.3 \\
(3,164-3,236)\end{array}$ & $\begin{array}{l}21.9 \\
(72)\end{array}$ & DA, SC & $\begin{array}{c}\mathrm{TS}, \mathrm{XRD} \\
\times \mathrm{XF} \\
\mathrm{Fe}^{2+} / \mathrm{Fe}^{3+}\end{array}$ & 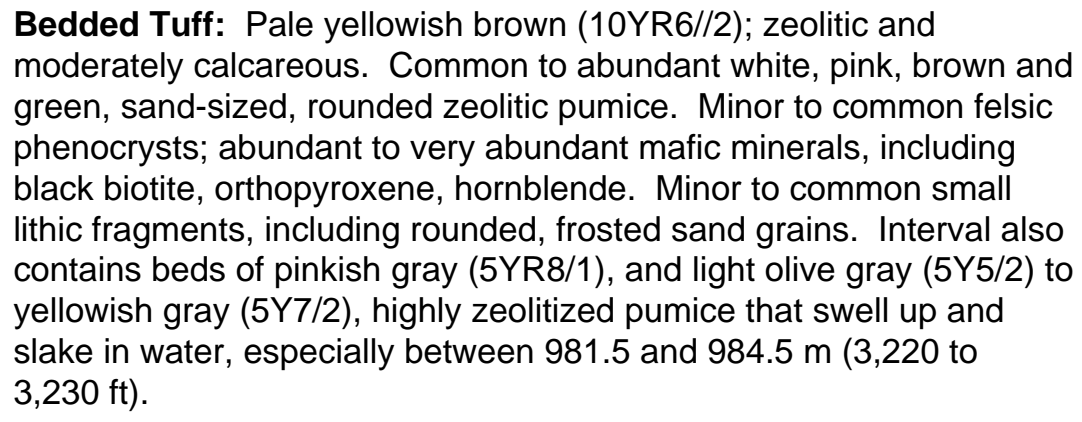 & \multirow{3}{*}{$\begin{array}{l}\text { Wahmonie } \\
\text { Formation }\end{array}$} \\
\hline $\begin{array}{l}986.3-1,002.8 \\
(3,236-3,290)\end{array}$ & $\begin{array}{l}16.5 \\
(54)\end{array}$ & $\begin{array}{c}\mathrm{DA} / \mathrm{DB} 2 \\
\mathrm{SC}\end{array}$ & $\begin{array}{c}\mathrm{TS}, \mathrm{XRD} \\
\times \mathrm{XF} \\
\mathrm{Fe}^{2+} / \mathrm{Fe}^{3+}\end{array}$ & $\begin{array}{l}\text { Nonwelded Ash-Flow Tuff: Moderate reddish brown (10R4/6) to } \\
\text { pale reddish brown (10R5/4) near base; devitrified. Rare light } \\
\text { brownish gray (5YR6/1) pumice with vapor phase crystallization. } \\
\text { Abundant felsic phenocrysts, including sparse quartz; very abundant } \\
\text { mafic minerals, including black biotite and much lesser } \\
\text { orthopyroxene. Minor lithic fragments. Contains interbeds of } \\
\text { moderate brown (5YR3/4) fine grained tuffaceous sandstone, } \\
\text { especially between } 987.6 \text { and 1,002.8 } \mathrm{m}(3,240 \text { and } 3,290 \mathrm{ft}) \text {, similar } \\
\text { to those described within the interval } 931.2 \text { - } 964.4 \mathrm{~m}(3,055 \text { - } \\
3,164 \mathrm{ft}) \text {. }\end{array}$ & \\
\hline $\begin{array}{c}1,002.8-1,010.4 \\
(3,290-3,315)\end{array}$ & $\begin{array}{c}7.6 \\
(25)\end{array}$ & $\begin{array}{l}\text { DB1, } \\
\text { SC }\end{array}$ & TS, XRD & $\begin{array}{l}\text { Nonwelded Ash-Flow Tuff: Pale yellowish brown (10YR6/2) to } \\
\text { moderate yellowish brown (10YR5/4) and light brown (5YR6/4); } \\
\text { zeolitic, quartzo-feldspathic in places. Minor grayish orange pink } \\
\text { (5YR7/2) zeolitized pumice; also grayish brown (5YR3/2) pumice with } \\
\text { vapor phase crystallization. Minor to common felsic phenocrysts; } \\
\text { abundant to very abundant black biotite. Common lithic fragments, } \\
\text { mostly subrounded volcanic rocks. (Lithic fragments may be over- } \\
\text { represented in cuttings). }\end{array}$ & \\
\hline
\end{tabular}




\begin{tabular}{|c|c|c|c|c|c|}
\hline $\begin{array}{c}\text { Depth } \\
\text { Interval }^{1} \\
\text { meters }^{2} \\
\text { (feet) } \\
\end{array}$ & $\begin{array}{l}\text { Thickness } \\
\text { meters } \\
\text { (feet) }\end{array}$ & $\begin{array}{c}\text { Sample } \\
\text { Type }^{2}\end{array}$ & $\begin{array}{l}\text { Laboratory } \\
\text { Analyses }^{3}\end{array}$ & Lithologic Description ${ }^{4}$ & $\underset{\text { Unit }}{\text { Stratigraphic }}$ \\
\hline $\begin{array}{c}1,010.4-1,033.3 \\
(3,315-3,390)\end{array}$ & $\begin{array}{l}22.9 \\
(75)\end{array}$ & DA, SC & $\begin{array}{c}\mathrm{TS}, \mathrm{XRD} \\
\text { XRF, } \\
\mathrm{Fe}^{2+} / \mathrm{Fe}^{3+}\end{array}$ & $\begin{array}{l}\text { Bedded Tuff: Moderate brown (5YR4/4); slightly calcareous in } \\
\text { places, well indurated, quartzo-feldspathic and argillic. Minor tiny } \\
\text { white zeolitized pumice. Common tiny felsic phenocrysts with milky } \\
\text { white alteration; common to abundant tiny mafic minerals. No lithic } \\
\text { fragments observed in samples. }\end{array}$ & \multirow{4}{*}{$\begin{array}{c}\text { Salyer } \\
\text { Member, } \\
\text { Wahmonie } \\
\text { Formation }\end{array}$} \\
\hline $\begin{array}{c}1,033.3-1,040.9 \\
(3,390-3,415)\end{array}$ & $\begin{array}{c}7.6 \\
(25)\end{array}$ & $\mathrm{DA}, \mathrm{SC}$ & None & $\begin{array}{l}\text { Nonwelded to Partially Welded Ash-Flow Tuff: Pale yellowish } \\
\text { brown (10YR6/2) to pale brown (5YR5/2) and moderate brown } \\
\text { (5YR4/4); zeolitic. Minor white to light red (5R6/6) and grayish } \\
\text { orange pink (5YR7/2) zeolitized pumice. In places, pumice is silicified } \\
\text { and grayish brown (5YR3/2). Minor felsic phenocrysts. Abundant to } \\
\text { very abundant mafic minerals, including black biotite and } \\
\text { orthopyroxene. Minor to common lithic fragments. }\end{array}$ & \\
\hline $\begin{array}{c}1,040.9-1,071.4 \\
(3,415-3,515)\end{array}$ & $\begin{array}{l}30.5 \\
(100)\end{array}$ & DA, SC & $\begin{array}{c}\mathrm{TS}, \mathrm{XRD} \\
\text { XRF, } \\
\mathrm{Fe}^{2+} / \mathrm{Fe}^{3+}\end{array}$ & $\begin{array}{l}\text { Partially Welded to Nonwelded Ash-Flow Tuff: Medium gray (N5) } \\
\text { to greenish gray (5GY6/1) to light olive gray (5Y6/1); slightly } \\
\text { calcareous, zeolitic. Minor small whitish to moderate yellowish green } \\
\text { (5GY7/4) and light olive gray (5Y6/1) zeolitized pumice. Some } \\
\text { pumice is dark greenish gray (5GY4/1) and silicified. Minor to } \\
\text { common felsic phenocrysts; very abundant black biotite. Minor to } \\
\text { common lithic fragments. }\end{array}$ & \\
\hline $\begin{array}{c}1,071.4-1,088.1 \\
(3,515-3,570)\end{array}$ & $\begin{array}{l}16.8 \\
(55)\end{array}$ & $\mathrm{DA}, \mathrm{SC}$ & $\begin{array}{c}\text { TS, XRD } \\
\text { XRF, } \\
\mathrm{Fe}^{2+} / \mathrm{Fe}^{3+}\end{array}$ & $\begin{array}{l}\text { Nonwelded Ash-Flow Tuff: Grayish orange pink (5YR7/2) to pale } \\
\text { brown ( } 5 \text { YR5/2); pale olive (10Y6/2) near top of interval; zeolitic. } \\
\text { Common white and light olive (10Y5/4) to dark gray (N3) zeolitized } \\
\text { pumice, moderate yellowish green (5GY7/4) near top of interval. } \\
\text { Minor to common felsic phenocrysts; common to abundant mafic } \\
\text { minerals, including biotite and much lesser hornblende. Minor lithic } \\
\text { fragments up to } 5 \mathrm{~mm} \text { in size. }\end{array}$ & \\
\hline
\end{tabular}




\begin{tabular}{|c|c|c|c|c|c|}
\hline $\begin{array}{l}\text { Depth } \\
\text { Interval }^{1} \\
\text { meters } \\
\text { (feet) }\end{array}$ & $\begin{array}{c}\text { Thickness } \\
\text { meters } \\
\text { (feet) }\end{array}$ & $\begin{array}{c}\text { Sample } \\
\text { Type }^{2}\end{array}$ & $\begin{array}{l}\text { Laboratory } \\
\text { Analyses }^{3}\end{array}$ & Lithologic Description ${ }^{4}$ & $\begin{array}{c}\text { Stratigraphic } \\
\text { Unit }\end{array}$ \\
\hline $\begin{array}{c}1,088.1-1,104.9 \\
(3,570-3,625)\end{array}$ & $\begin{array}{r}16.8 \\
(55)\end{array}$ & DA, SC & None & $\begin{array}{l}\text { Nonwelded to Partially Welded Ash-Flow Tuff: Pale reddish brown } \\
\text { (10R5/4) to pale brown (5YR5/2); zeolitic and/or argillic. Minor to } \\
\text { common white and light greenish gray ( } 5 \mathrm{GY} 8 / 1 \text { ) zeolitized pumice. } \\
\text { Minor to common felsic phenocrysts; common to abundant black } \\
\text { biotite. Minor small lithic fragments. }\end{array}$ & \multirow{4}{*}{$\begin{array}{l}\text { Salyer } \\
\text { Member, } \\
\text { Wahmonie } \\
\text { Formation }\end{array}$} \\
\hline $\begin{array}{c}1,104.9-1,114.3 \\
(3,625-3,656)\end{array}$ & $\begin{array}{c}9.4 \\
(31)\end{array}$ & DA, SC & $\begin{array}{c}\text { TS, XRD } \\
\text { XRF, } \\
\mathrm{Fe}^{2+} / \mathrm{Fe}^{3+}\end{array}$ & $\begin{array}{l}\text { Bedded Tuff: Pale reddish brown (10R5/4) to pale red (10R6/2); } \\
\text { zeolitized. Abundant small pale reddish brown (10R5/4), white, and } \\
\text { light greenish gray rounded, zeolitized pumice. Minor felsic } \\
\text { phenocrysts; minor to common biotite. Rare small lithic fragments. } \\
\text { Contains patches of silicification. Toward base, rock is pale red } \\
\text { (10R6/2) to grayish red (10R4/2) ash-fall tuff with very abundant, } \\
\text { moderate yellowish green (5GY } 7 / 4) \text {, zeolitized, angular pumice. Also } \\
\text { toward base, lithic fragments increase to minor, felsic phenocrysts } \\
\text { become common and include quartz; mafic minerals increase slightly } \\
\text { and include orthopyroxene. }\end{array}$ & \\
\hline $\begin{array}{c}1,114.3-1,136.6 \\
3,656-3,729\end{array}$ & $\begin{array}{l}22.3 \\
(73)\end{array}$ & DA, SC & None & $\begin{array}{l}\text { Nonwelded Ash-Flow Tuff: Pale reddish brown (10R5/4) to } \\
\text { moderate reddish orange (10R6/6) and moderate reddish brown } \\
\text { (10R4/6); zeolitic. Common to abundant white to greenish gray } \\
\text { (5GY6/1) zeolitized pumice. Minor to common felsic phenocrysts; } \\
\text { minor mafic minerals of biotite, orthopyroxene, hornblende. Minor } \\
\text { lithic fragments including rounded siltstone fragments. }\end{array}$ & \\
\hline $\begin{array}{c}1,136.6-1,157.0 \\
(3,729-3,796)\end{array}$ & $\begin{array}{l}20.4 \\
(67)\end{array}$ & $\begin{array}{c}\text { DB2/DA } \\
\text { SC }\end{array}$ & $\begin{array}{c}\mathrm{TS}, \mathrm{XRD} \\
\text { XRF, } \\
\mathrm{Fe}^{2+} / \mathrm{Fe}^{3+}\end{array}$ & $\begin{array}{l}\text { Nonwelded Ash-Flow Tuff: Pale reddish brown (10R5/4), with } \\
\text { patches of moderate reddish brown (10R4/6) silicification; zeolitc. } \\
\text { Minor to common, white to pale red (10R6/2) and dark yellowish } \\
\text { green (10GY4/4) zeolitized pumice. Minor to common felsic } \\
\text { phenocrysts, including quartz; rare biotite. Sidewall core at } 1,143 \mathrm{~m} \\
\text { ( } 3,750 \mathrm{ft}) \text { contains magnetite phenocrysts surrounded by iron oxide } \\
\text { haloes. Common lithic fragments of angular quartzite (seen in } \\
\text { sidewall core at } 1,143 \text { m [3,750 ft]) and rounded, very dusky red } \\
\text { (10R2/2) siltstone (conspicuous in cuttings). Interval is poorly } \\
\text { represented in cuttings; description based largely on sidewall cores. }\end{array}$ & \\
\hline
\end{tabular}




\begin{tabular}{|c|c|c|c|c|c|}
\hline $\begin{array}{l}\text { Depth } \\
\text { Interval }^{1} \\
\text { meters } \\
\text { (feet) }\end{array}$ & $\begin{array}{l}\text { Thickness } \\
\text { meters } \\
\text { (feet) }\end{array}$ & $\begin{array}{c}\text { Sample } \\
\text { Type }^{2}\end{array}$ & $\begin{array}{l}\text { Laboratory } \\
\text { Analyses }^{3}\end{array}$ & Lithologic Description ${ }^{4}$ & $\underset{\text { Unit }}{\text { Stratigraphic }}$ \\
\hline $\begin{array}{c}1,157.0-1,181.4 \\
(3,796-3,876)\end{array}$ & $\begin{array}{r}24.4 \\
(80)\end{array}$ & $\mathrm{DA}, \mathrm{SC}$ & None & $\begin{array}{l}\text { Bedded Tuff: Fine grained tuffaceous sandstone. Pale reddish } \\
\text { brown (10R5/4) to dark reddish brown (10R3/4); calcareous. Minor } \\
\text { white, zeolitic pumice. Common felsic phenocrysts; common biotite } \\
\text { in disaggregated masses. Minor sand-sized lithic fragments. }\end{array}$ & \multirow{4}{*}{ Bullfrog Tuff } \\
\hline $\begin{array}{c}1,181.4-1,194.8 \\
(3,876-3,920)\end{array}$ & $\begin{array}{l}13.4 \\
(44)\end{array}$ & $\mathrm{DA}, \mathrm{SC}$ & $\begin{array}{c}\text { TS, XRD } \\
\text { XRF, } \\
\mathrm{Fe}^{2+} / \mathrm{Fe}^{3+}\end{array}$ & $\begin{array}{l}\text { Nonwelded to Partially Welded Ash-Flow Tuff: Grayish red } \\
\text { (10R4/2) and grayish orange (10YR7/4); mottled, giving an overall } \\
\text { color of pale reddish brown (10R5/4); zeolitic. Abundant to common } \\
\text { very pale orange (10YR8/2), zeolitized pumice with remnant fibrous } \\
\text { structure. Minor felsic phenocrysts, feldspar and quartz; abundant } \\
\text { mafic minerals, biotite with lesser hornblende. Minor dark-colored } \\
\text { fine-grained, subangular to subrounded volcanic lithic fragments. }\end{array}$ & \\
\hline $\begin{array}{c}1,194.8-1,200.9 \\
(3,920-3,940)\end{array}$ & $\begin{array}{c}6.1 \\
(20)\end{array}$ & $\mathrm{DA}, \mathrm{SC}$ & None & $\begin{array}{l}\text { Partially Welded Ash-Flow Tuff: Pale red (10R6/2); devitrified. } \\
\text { Minor to common white and yellowish gray, zeolitic pumice. Common } \\
\text { felsic phenocrysts, including feldspar and quartz; abundant black } \\
\text { biotite. Minor angular lithic fragments. }\end{array}$ & \\
\hline $\begin{array}{c}1,200.9-1,225.9 \\
(3,940-4,022)\end{array}$ & $\begin{array}{l}25.0 \\
(82)\end{array}$ & $\begin{array}{l}\text { DB2/DA } \\
\text { SC }\end{array}$ & $\begin{array}{c}\text { TS, XRD } \\
\text { XRF, } \\
\mathrm{Fe}^{2+} / \mathrm{Fe}^{3+}\end{array}$ & $\begin{array}{l}\text { Partially Welded Ash-Flow Tuff: Pale yellowish brown (10YR6/2); } \\
\text { devitrified. Minor dark yellowish brown (10YR4/2) flattened, zeolitic } \\
\text { pumice. Minor to common felsic phenocrysts; common to abundant } \\
\text { black biotite. Minor lithic fragments up to } 8 \mathrm{~mm} \text { long. Abundant } \\
\text { caved material in cuttings. }\end{array}$ & \\
\hline
\end{tabular}




\begin{tabular}{|c|c|c|c|c|c|}
\hline $\begin{array}{l}\text { Depth } \\
\text { Interval }^{1} \\
\text { meters } \\
\text { (feet) }\end{array}$ & $\begin{array}{l}\text { Thickness } \\
\text { meters } \\
\text { (feet) }\end{array}$ & $\begin{array}{c}\text { Sample } \\
\text { Type }^{2}\end{array}$ & $\begin{array}{l}\text { Laboratory } \\
\text { Analyses }^{3}\end{array}$ & Lithologic Description ${ }^{4}$ & $\underset{\text { Unit }}{\text { Stratigraphic }}$ \\
\hline $\begin{array}{c}1,225.9-1,377.7 \\
(4,022-4,520)\end{array}$ & $\begin{array}{l}151.8 \\
(498)\end{array}$ & DB4 & $\begin{array}{c}\mathrm{TS}, \mathrm{XRD} \\
\mathrm{XRF} \\
\mathrm{Fe}^{2+} / \mathrm{Fe}^{3+}\end{array}$ & $\begin{array}{l}\text { Bedded and/or Nonwelded Tuff: Very pale orange (10YR8/2) and } \\
\text { grayish olive (10Y4/2); zeolitic. Common tiny white and light pink } \\
\text { zeolitic pumice. Very abundant felsic phenocrysts, including } \\
\text { subhedral quartz; common black biotite decreasing with depth, rare } \\
\text { clinopyroxene. Common fragments of quartzite and silicified volcanic } \\
\text { rocks, apparently increasing with depth. Intergrown subhedral quartz } \\
\text { crystals up to } 8 \mathrm{~mm} \text { long, and botryoidal cristobalite found loose in } \\
\text { box are thought to be associated with this lithology because of pinkish } \\
\text { matrix coatings, but probably formed secondarily in fractures and } \\
\text { cavities. Below } 1,258.8 \mathrm{~m}(4,130 \mathrm{ft}) \text { (in cuttings) tuff contains nodules } \\
\text { or lenses of yellowish gray (5Y7/2) silicification (quartzo-feldspathic } \\
\text { alteration) which increases until silicified fragments showing } \\
\text { conchoidal fracture are common in cuttings (especially } 1,332.0 \text { - } \\
1,335.0 \mathrm{~m}[4,370 \text { - } 4,380 \mathrm{ft}]) \text {. Abundant mixing of cuttings with caved } \\
\text { material; bedded tuff described is thought most likely to be } \\
\text { representative of interval, because it is dissimilar to any lithologies } \\
\text { found up-hole. Geophysical logs suggest the presence of other, } \\
\text { unrecognized lithologies within this interval. }\end{array}$ & \multirow[t]{2}{*}{ Bullfrog Tuff } \\
\hline $\begin{array}{c}1,377.7-1,425.9 \\
(4,520-4,678)\end{array}$ & $\begin{array}{c}48.2 \\
(158)\end{array}$ & $\begin{array}{c}\text { DA/DB2 } \\
\text { SC }\end{array}$ & TS & $\begin{array}{l}\text { Nonwelded Tuff: Pale yellowish green (10GY7/2); zeolitic and } \\
\text { quartzo-feldspathic; slightly calcareous in places. Rare to minor } \\
\text { zeolitic green pumice; common felsic phenocrysts; minor to common } \\
\text { black biotite. }\end{array}$ & \\
\hline $\begin{array}{c}1,425.9-1,493.5 \\
(4,678-4,900)\end{array}$ & $\begin{array}{l}67.7 \\
(222)\end{array}$ & $\begin{array}{c}\text { DA/DB2 } \\
\text { SC }\end{array}$ & $\begin{array}{c}\mathrm{TS}, \mathrm{XRD} \\
\text { XRF, } \\
\mathrm{Fe}^{2+} / \mathrm{Fe}^{3+}\end{array}$ & $\begin{array}{l}\text { Dolomite: Grayish orange pink (5YR7/2) to moderate orange pink } \\
(10 R 7 / 4) \text {, and light gray (N7) to medium light gray (N6) with indistinct } \\
\text { banding in places; well indurated. Medium crystalline (crystal faces } \\
\text { typically } 0.25 \mathrm{~mm}) \text {. Fractures less than } 1 \mathrm{~mm} \text { wide are commonly } \\
\text { healed with moderate reddish orange (10R6/6) iron oxide; fractures } \\
\text { more than } 1 \mathrm{~mm} \text { wide are healed with calcite. Brecciated at top of } \\
\text { interval, with angular fragments of dolomite cemented in very pale } \\
\text { orange (10YR8/2) to white, medium to coarsely crystalline calcite } \\
\text { matrix. }\end{array}$ & $\begin{array}{l}\text { Paleozoic } \\
\text { rocks, } \\
\text { undivided }\end{array}$ \\
\hline
\end{tabular}




\begin{tabular}{||c|c|c|c|l||}
\hline $\begin{array}{c}\text { Depth } \\
\text { Interval } \\
\text { meters } \\
(\mathrm{feet})\end{array}$ & $\begin{array}{c}\text { Thickness } \\
\text { meters } \\
(\mathrm{feet})\end{array}$ & $\begin{array}{c}\text { Sample } \\
\text { Type }^{2}\end{array}$ & $\begin{array}{c}\text { Laboratory } \\
\text { Analyses }^{3}\end{array}$ & $\begin{array}{c}\text { Stratigraphic } \\
\text { Unit }\end{array}$ \\
\hline \hline $\begin{array}{c}1,493.5-1,732.2 \\
(4,900-5,683) \\
(\mathrm{TD})\end{array}$ & $\begin{array}{c}>237.8 \\
(>780)\end{array}$ & DA/DB2 & None & $\begin{array}{l}\text { Dolomite: Medium gray (N5) to grayish black (N2); finely crystalline. } \\
\text { Common very light gray (N8) calcite veins, sparse iron oxide staining. } \\
\text { Rare indistinct ooliths to } 0.5 \text { mm in size. }\end{array}$ \\
\hline
\end{tabular}

1. Geophysical logs not available within cased interval (0 - 848.6 $\mathrm{m}[0-2,784 \mathrm{ft}])$. Depths in this interval are based on cuttings samples and correlation with Well ER-5-3.

2. $\mathbf{D A}=$ drill cuttings that represent lithologic character of interval; $\mathbf{D B} 1=$ drill cuttings enriched in hard components; $\mathbf{D B 2}=$ cuttings from interval different than that drilled; DB4 = cuttings that are intimate mixtures of units; $\mathbf{S C}=$ sidewall core.

3. $\mathbf{T S}=$ polished thin section $\mathbf{X R D}=\mathrm{x}$-ray diffraction; $\mathbf{X R F}=\mathrm{x}$-ray fluorescence; $\mathbf{F e}^{2+} / \mathbf{F e}^{3+}=$ wet chemical analysis for iron. See Table $3-3$ of this report for additional information.

4. Descriptions are based mainly on visual examination of lithologic samples using a 10x- to 40x-zoom binocular microscope, and incorporating observations from geophysical logs and results of laboratory analyses. Colors describe wet sample color.

Abundances for felsic phenocrysts, pumice fragments, and lithic fragments: trace $=$ only one or two individuals observed; rare $=\leq 1 \%$;

minor $=5 \%$; common $=10 \% ;$ abundant $=15 \%$; very abundant $>20 \%$.

Abundances for mafic minerals: trace $=$ only one or two individuals observed; rare $=\leq 0.05 \%$; minor $=0.2 \%$; common $=10 \%$; abundant $=1 \%$; very abundant $=\geq 2 \% . k$. 


\section{Appendix C-3 \\ Detailed Lithologic Log for Well ER-5-3\#3}


Detailed Lithologic Log for Well ER-5-3\#3

Logged by Heather Huckins-Gang, Bechtel Nevada

June 25, 2001

\begin{tabular}{|c|c|c|c|c|c|}
\hline $\begin{array}{c}\text { Depth } \\
\text { Interval }^{1} \\
\text { meters }^{-} \\
\text {(feet) } \\
\end{array}$ & $\begin{array}{l}\text { Thickness } \\
\text { meters } \\
\text { (feet) }\end{array}$ & $\begin{array}{l}\text { Sample } \\
\text { Type }^{2}\end{array}$ & $\begin{array}{c}\text { Laboratory } \\
\text { Analyses }\end{array}$ & Lithologic Description $^{3}$ & $\underset{\text { Unit }}{\text { Stratigraphic }}$ \\
\hline $\begin{array}{l}0-185.9 \\
(0-610)\end{array}$ & $\begin{array}{l}185.9 \\
(610)\end{array}$ & $\begin{array}{l}\text { DB1 } \\
\text { No } \\
\text { samples to } \\
36.6 \mathrm{~m} \\
(120 \mathrm{ft})\end{array}$ & none & $\begin{array}{l}\text { Alluvium: Gravelly sand and sandy gravel; matrix of alluvium is } \\
\text { not represented in washed cuttings. (Sidewall cores from the } \\
\text { corresponding interval in Well ER-5-3 show matrix is poorly } \\
\text { indurated, poorly sorted, tuffaceous, moderate yellowish brown } \\
\text { (10YR5/4), moderately to highly calcareous, medium to very fine } \\
\text { silty sand.) Gravel clasts are almost entirely tuff. Less than } \\
5 \text { percent limestone and quartzite clasts. Very rare basalt clasts. } \\
\text { Thin, discontinuous carbonate coats are typically seen on up to } \\
50 \text { percent of clasts. Most coated (i.e. unbroken) clasts are sub- } \\
\text { angular to sub-rounded coarse sand and pebbles. }\end{array}$ & \multirow{2}{*}{$\begin{array}{c}\text { Quaternary o } \\
\text { Tertiary } \\
\text { alluvium }\end{array}$} \\
\hline $\begin{array}{c}185.9-277.4 \\
(610-910)\end{array}$ & $\begin{array}{l}91.4 \\
(300)\end{array}$ & DA, DB1 & none & $\begin{array}{l}\text { Alluvium: Gravelly sand and sandy gravel; moderately indurated. } \\
\text { Pale yellowish brown (10YR6/2) to moderate yellowish brown } \\
\text { (10YR 5/4), moderately to highly calcareous, zeolitized, tuffaceous, } \\
\text { sandy matrix is conspicuous in cuttings as fragments and thick } \\
\text { coatings on clasts. Gravel clasts are predominantly very light gray } \\
\text { and grayish red tuff. Below about } 213.4 \mathrm{~m} \text { ( } 700 \mathrm{ft}) \text {, gradual } \\
\text { increase in basalt clasts and quartzite clasts. Near base of interval, } \\
\text { minor small drusy calcite coatings on small vugs and fracture faces } \\
\text { were noted. }\end{array}$ & \\
\hline $\begin{array}{c}277.4-289.6 \\
(910-950)\end{array}$ & $\begin{array}{l}12.2 \\
(40)\end{array}$ & DA & none & $\begin{array}{l}\text { Basalt: Grayish black (N2), well indurated, porphyritic with finely } \\
\text { crystalline groundmass of clinopyroxene and plagioclase. } \\
\text { Conspicuous olivine, mostly altered to moderate reddish brown } \\
\text { (10R4/6) iddingsite. Conspicuous small (less than } 2 \mathrm{~mm} \text { ) vesicles } \\
\text { filled with smectite. }\end{array}$ & $\begin{array}{l}\text { Basalt of } \\
\text { Frenchman } \\
\text { Flat }\end{array}$ \\
\hline
\end{tabular}




\begin{tabular}{|c|c|c|c|c|c|}
\hline $\begin{array}{c}\text { Depth } \\
\text { Interval }^{1} \\
\text { meters } \\
\text { (feet) }\end{array}$ & $\begin{array}{c}\text { Thickness } \\
\text { meters } \\
\text { (feet) }\end{array}$ & $\begin{array}{c}\text { Sample } \\
\text { Type }^{2}\end{array}$ & $\begin{array}{c}\text { Laboratory } \\
\text { Analyses }\end{array}$ & Lithologic Description $^{3}$ & $\underset{\text { Unit }}{\text { Stratigraphic }}$ \\
\hline $\begin{array}{c}289.6-548.6 \\
(950-1,800) \\
\text { TD }\end{array}$ & $\begin{array}{l}259.1 \\
(850)\end{array}$ & DA & none & $\begin{array}{l}\text { Alluvium: Gravelly sand, sand, and gravelly, zeolitic or weakly } \\
\text { argillic sand; poorly to moderately sorted; moderately indurated. } \\
\text { Moderate yellowish brown (10YR } 5 / 4) \text {, tuffaceous, sandy matrix. } \\
\text { Matrix typically moderately calcareous, but varies from non- } \\
\text { calcareous to highly calcareous. Matrix is light brown (5YR5/6) in } \\
\text { upper } 1.5 \mathrm{~m} \text { ( } 5 \mathrm{ft} \text { ), probably altered by contact with the overlying } \\
\text { basalt flow. Minor small vugs and fracture faces lined with drusy } \\
\text { calcite, and possibly other minerals, are found throughout interval. } \\
\text { Gravel clasts are approximately equal parts volcanic and Paleozoic } \\
\text { clasts at top of interval, but quartzite percentages increase with } \\
\text { depth to a high of approximately } 80 \text { percent at } 420.6 \text { - } 423.7 \mathrm{~m} \\
\text { (1,380 - } 1,390 \mathrm{ft}) \text {, after which they decrease again, though quartzite } \\
\text { remains predominant. Lesser chert and rare limestone. } \\
\text { Intermittently below } 475.5 \mathrm{~m} \text { (1,560 ft), beds and/or matrix of poorly } \\
\text { indurated, highly calcareous, clayey sand to sandy clay are } \\
\text { indicated by cuttings fragments stuck together by clay, and } \\
\text { occasional intact fragments of clay which effervesce violently in } \\
\text { hydrochloric acid and slake readily in water. A bedded tuff, } \\
\text { encountered at } 507.5 \text { to } 512.7 \mathrm{~m}(1,665 \text { to } 1,682 \mathrm{ft}) \text { in Well ER-5-3, } \\
\text { was represented in Well ER-5-3\#3 by several fragments in the } \\
\text { interval between } 509.0 \text { and } 518.2 \mathrm{~m} \text { (1,670 and } 1,700 \mathrm{ft}) \text {. Most of } \\
\text { these fragments are clayey, calcareous, altered ash with abundant } \\
\text { subangular white and pink, zeolitized pumice and varying amounts } \\
\text { of biotite and euhedral quartz. }\end{array}$ & $\begin{array}{l}\text { Pliocene } \\
\text { through } \\
\text { Miocene } \\
\text { alluvium }\end{array}$ \\
\hline
\end{tabular}

1 Depth intervals based on cuttings alone. No geophysical logs were run in Well ER-5-3\#3.

$2 \quad$ DA $=$ drill cuttings that represent lithologic character of interval; DB1 = drill cuttings enriched in hard components;

3 Descriptions are based mainly on visual examination of lithologic samples using a 10x- to 40x-zoom binocular microscope, and incorporating observations from nearby drill holes. Colors describe wet sample color.

Abundances for felsic phenocrysts, pumice fragments, and lithic fragments: trace = only one or two individuals observed; rare $=\leq 1 \%$;

minor $=5 \%$; common $=10 \%$; abundant $=15 \%$; very abundant $=\geq 20 \%$.

Abundances for mafic minerals: trace $=$ only one or two individuals observed; rare $=\leq 0.05 \%$; minor $=0.2 \%$; common $=0.5 \%$; abundant $=1 \%$; very abundant $=\geq 2 \%$. 


\section{Appendix D \\ Geophysical Logs Run in Wells ER-5-3 and ER-5-3\#2 \\ D-1 Geophysical Logs Run in Well ER-5-3 \\ D-2 Geophysical Logs Run in Well ER-5-3\#2}

No logs were run in Well ER-5-3\#3 for geology or hydrology data. 


\section{Appendix D-1 \\ Geophysical Logs Run in Well ER-5-3}


Table D-1

Well ER-5-3 Geophysical Logs Presented

\begin{tabular}{|c|c|c|c|c|}
\hline Log Type & $\begin{array}{c}\text { Run } \\
\text { Number }\end{array}$ & Date & \multicolumn{2}{|c|}{ 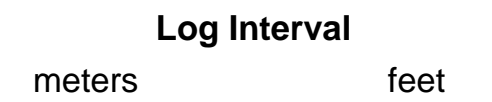 } \\
\hline Epithermal Neutron & $\begin{array}{l}\text { ENP-1 } \\
\text { ENP-2 }\end{array}$ & $\begin{array}{l}02 / 25 / 2000 \\
03 / 08 / 2000\end{array}$ & $\begin{array}{c}0-374.6 \\
257.9-780.3\end{array}$ & $\begin{array}{c}0-1,229 \\
846-2,560\end{array}$ \\
\hline Density & $\begin{array}{l}\text { CDL-1 } \\
\text { CDL-2 }\end{array}$ & $\begin{array}{l}02 / 25 / 2000 \\
03 / 08 / 2000\end{array}$ & $\begin{array}{c}0-374.6 \\
257.9-780.3\end{array}$ & $\begin{array}{c}0-1,229 \\
846-2,560\end{array}$ \\
\hline $\begin{array}{l}\text { Array Induction and Dual Laterolog } \\
\text { (resistivity) }\end{array}$ & $\begin{array}{l}\text { AIT-1 } \\
\text { DLL-1 }\end{array}$ & $\begin{array}{l}02 / 25 / 2000 \\
03 / 09 / 2000\end{array}$ & $\begin{array}{c}0-377.6 \\
374.9-776.3\end{array}$ & $\begin{array}{c}0-1,239 \\
1,230-2,547\end{array}$ \\
\hline Spontaneous Potential & SP-1 & $02 / 25 / 2000$ & $0-377.6$ & $0-1,239$ \\
\hline Gamma Ray & $\begin{array}{l}\text { GR-2 } \\
\text { GR-3 }\end{array}$ & $\begin{array}{l}02 / 25 / 2000 \\
03 / 08 / 2000\end{array}$ & $\begin{array}{c}0-374.6 \\
347.5-780.9\end{array}$ & $\begin{array}{c}0-1,229 \\
1,140-2,562\end{array}$ \\
\hline $\begin{array}{c}\text { Digital Array Sonic } \\
\text { (delta T and sonic porosity) }\end{array}$ & $A C-1$ & 03/08/2000 & $317.0-778.8$ & $1,040-2,555$ \\
\hline $\begin{array}{c}\text { Spectral Gamma Ray } \\
\text { (potassium, thorium, uranium) }\end{array}$ & $\begin{array}{l}\text { SGR-1 } \\
\text { SGR-2 }\end{array}$ & $\begin{array}{l}02 / 25 / 2000 \\
03 / 08 / 2000\end{array}$ & $\begin{array}{c}0-373.7 \\
362.7-769.3\end{array}$ & $\begin{array}{c}0-1,226 \\
1,190-2,524\end{array}$ \\
\hline Thermal Flow & 1 & $03 / 12 / 2000$ & $411.5-768.1$ & $1,350-2,520$ \\
\hline $\begin{array}{c}\text { Chemistry } \\
\text { (temperature, } \mathrm{pH} \text {, electrical conductivity) }\end{array}$ & 1 & 03/12/2000 & $282.5-780.9$ & $927-2,662$ \\
\hline
\end{tabular}




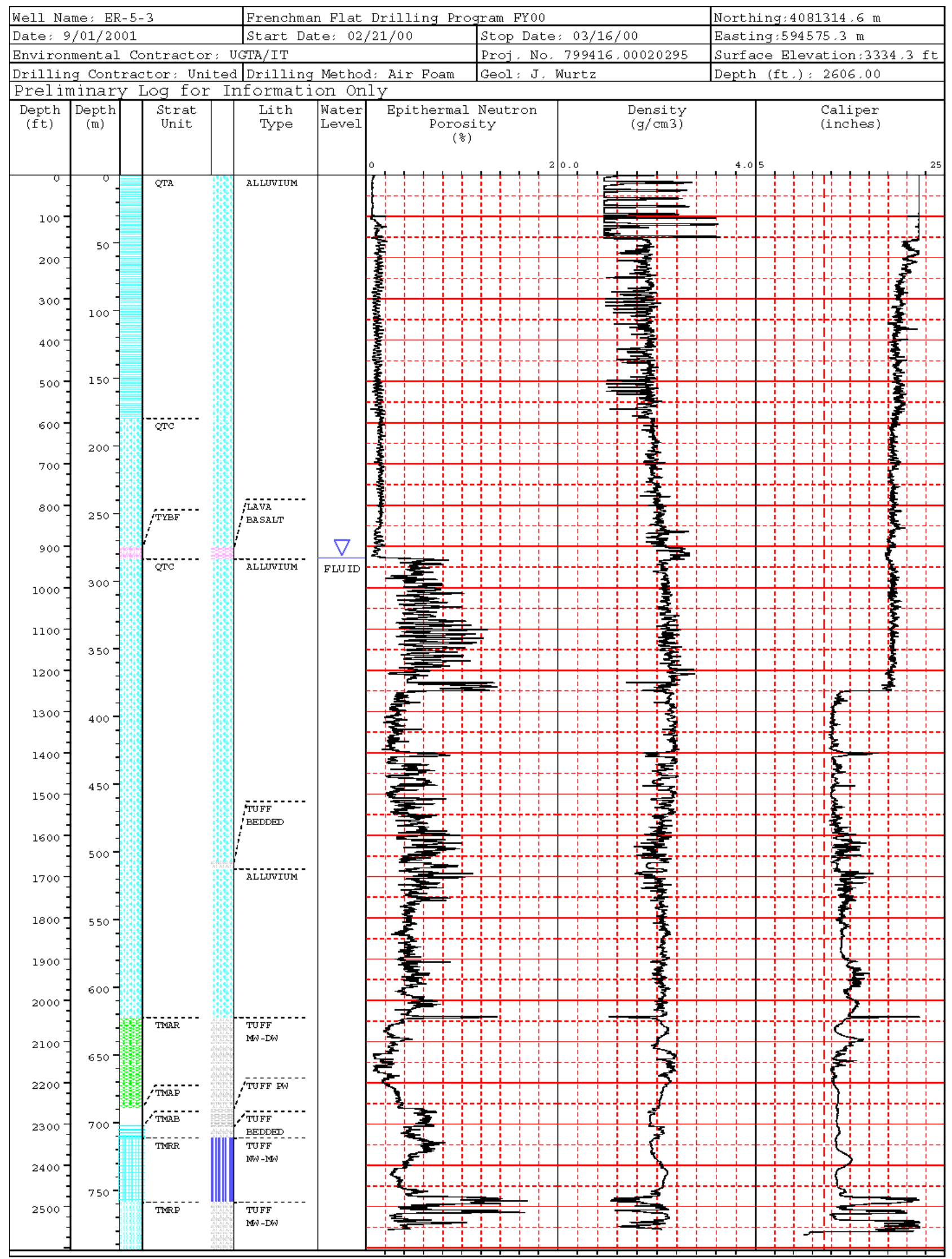

D-1-2 


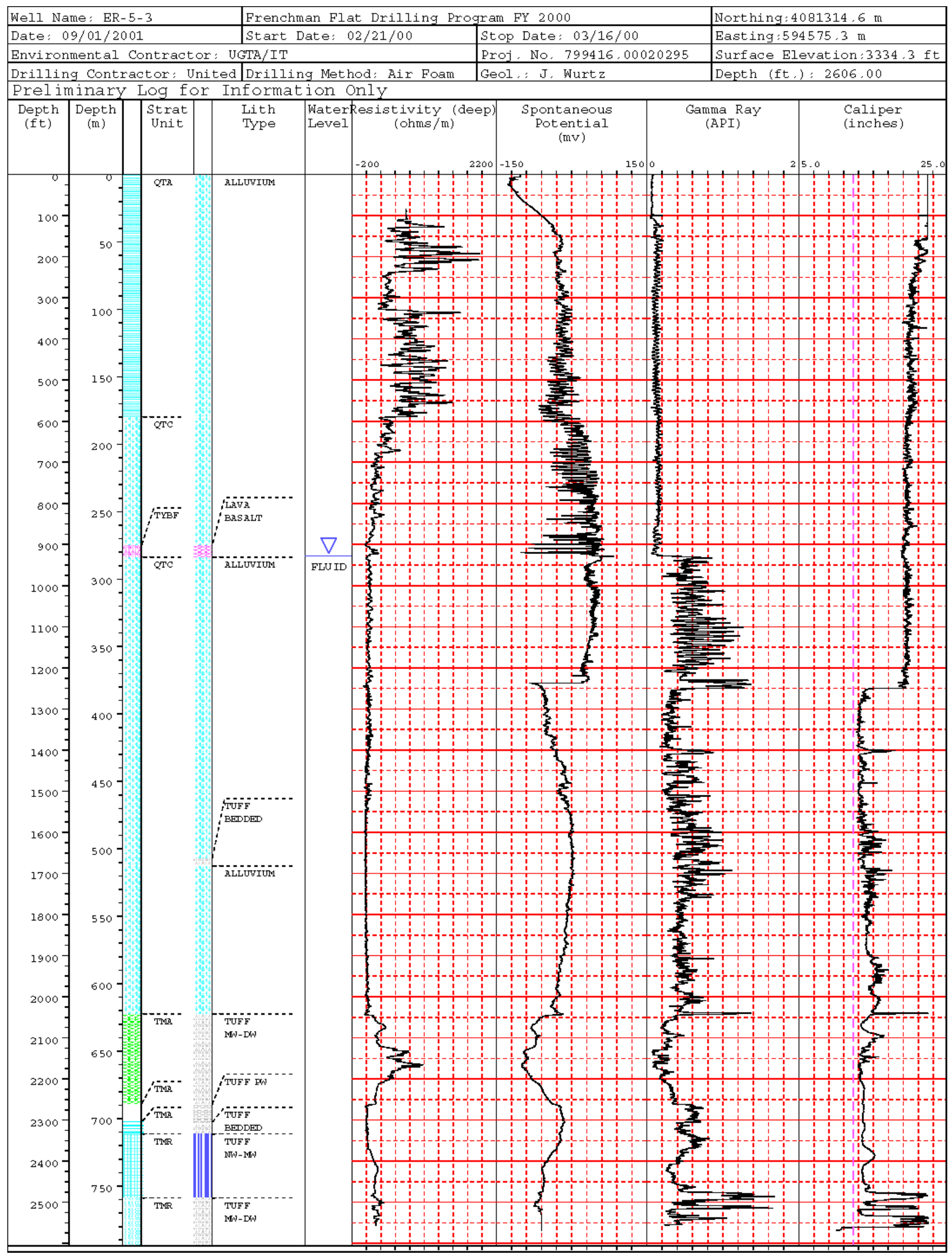

D-1-3 


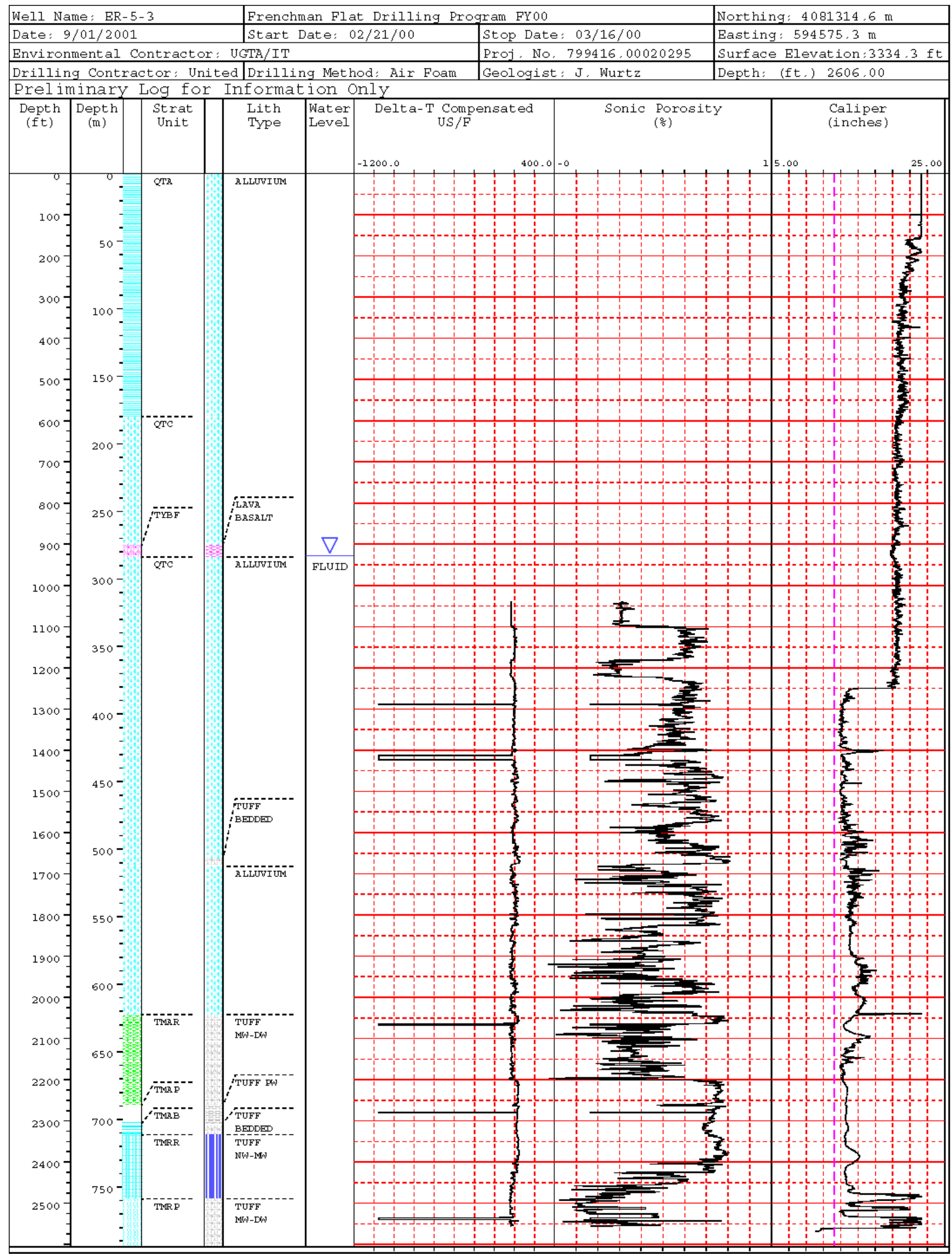




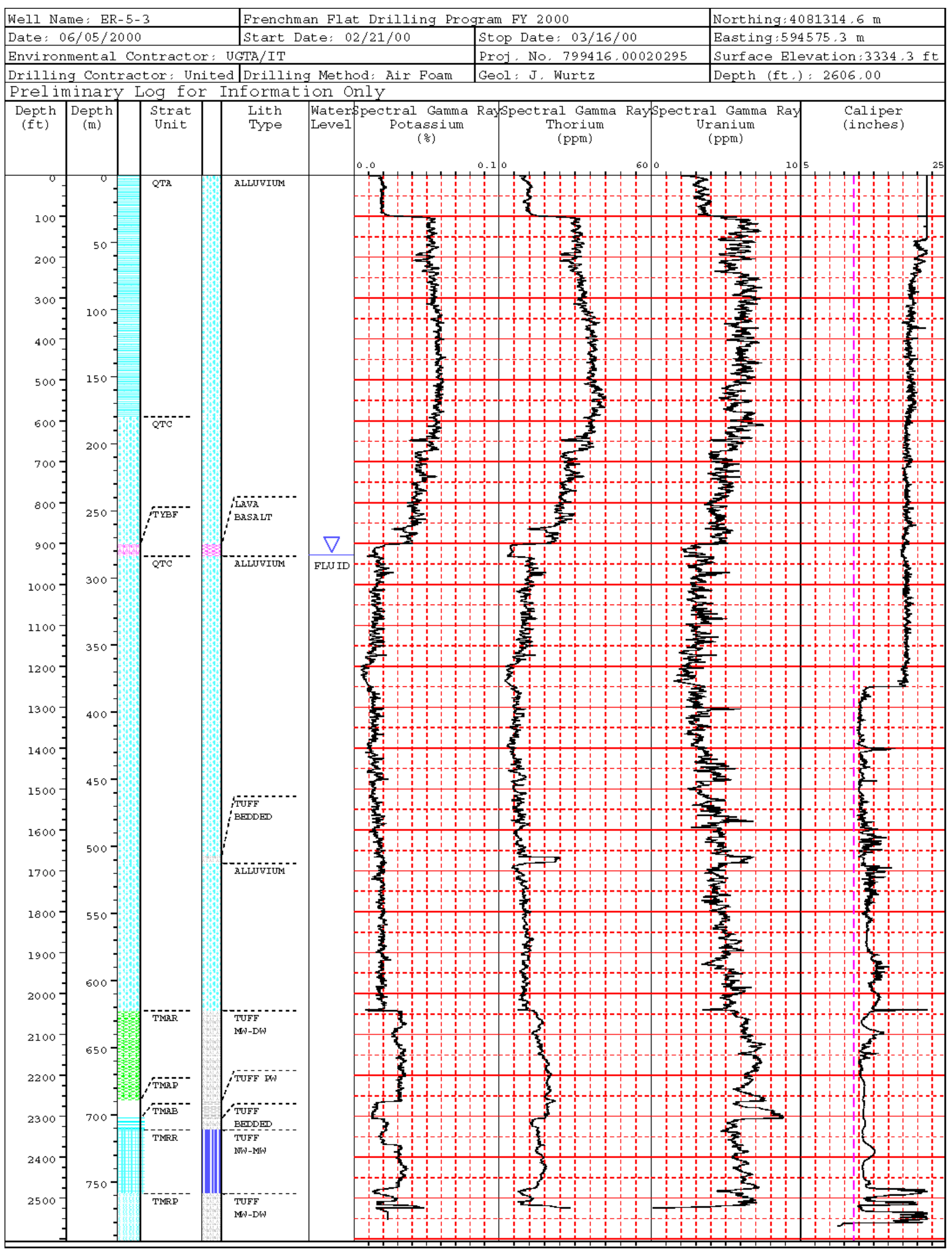

D-1-5 


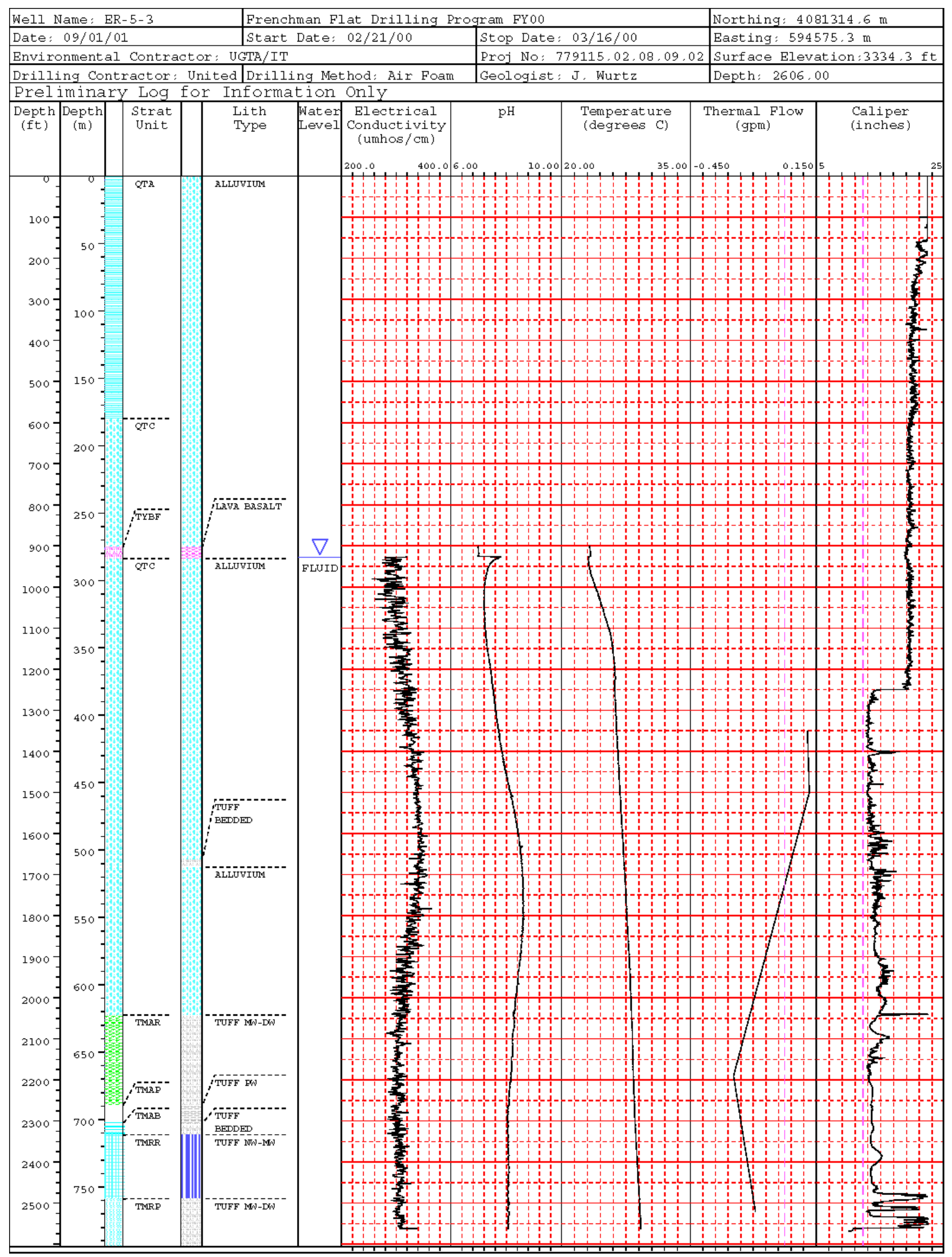




\section{Appendix D-2 \\ Geophysical Logs Run in Well ER-5-3\#2}


Table D-2

Well ER-5-3\#2 Geophysical Logs Presented

\begin{tabular}{|c|c|c|c|c|}
\hline Log Type & $\begin{array}{c}\text { Run } \\
\text { Number }\end{array}$ & Date & meters & $\begin{array}{ll}\text { rval } & \\
& \text { feet }\end{array}$ \\
\hline Epithermal Neutron & $\begin{array}{l}\text { ENP-1 } \\
\text { ENP-2 }\end{array}$ & $\begin{array}{l}05 / 06 / 2000 \\
05 / 10 / 2000\end{array}$ & $\begin{array}{c}714.5-1,204.6 \\
1,168.0-1,614.2\end{array}$ & $\begin{array}{l}2,344-3,952 \\
3,832-5,296\end{array}$ \\
\hline Density & $\begin{array}{l}\text { CDL-1 } \\
\text { CDL-2 }\end{array}$ & $\begin{array}{l}05 / 06 / 2000 \\
05 / 10 / 2000\end{array}$ & $\begin{array}{c}714.5-1,204.6 \\
1,168.0-1,614.2\end{array}$ & $\begin{array}{l}2,344-3,952 \\
3,832-5,296\end{array}$ \\
\hline $\begin{array}{l}\text { Dual Laterolog } \\
\text { (resistivity) }\end{array}$ & DLL-1 & $5 / 10 / 2000$ & $714.5-1,601.4$ & $2,344-5,254$ \\
\hline Spontaneous Potential & SP-2 & $05 / 10 / 2000$ & 714.5 - 1,601.4 & $2,344-5,254$ \\
\hline Gamma Ray & GR-5 & $05 / 10 / 2000$ & $829.7-1,614.2$ & $2,722-5,296$ \\
\hline $\begin{array}{c}\text { Digital Array Sonic } \\
\text { (delta } \mathrm{T} \text { and sonic porosity) }\end{array}$ & $A C-1$ & $05 / 10 / 2000$ & $714.5-1,596.5$ & $2,344-5,238$ \\
\hline $\begin{array}{c}\text { Spectral Gamma Ray } \\
\text { (potassium, thorium, uranium) }\end{array}$ & SGR-1 & $05 / 11 / 2000$ & $731.5-1,561.5$ & $2,400-5,123$ \\
\hline
\end{tabular}




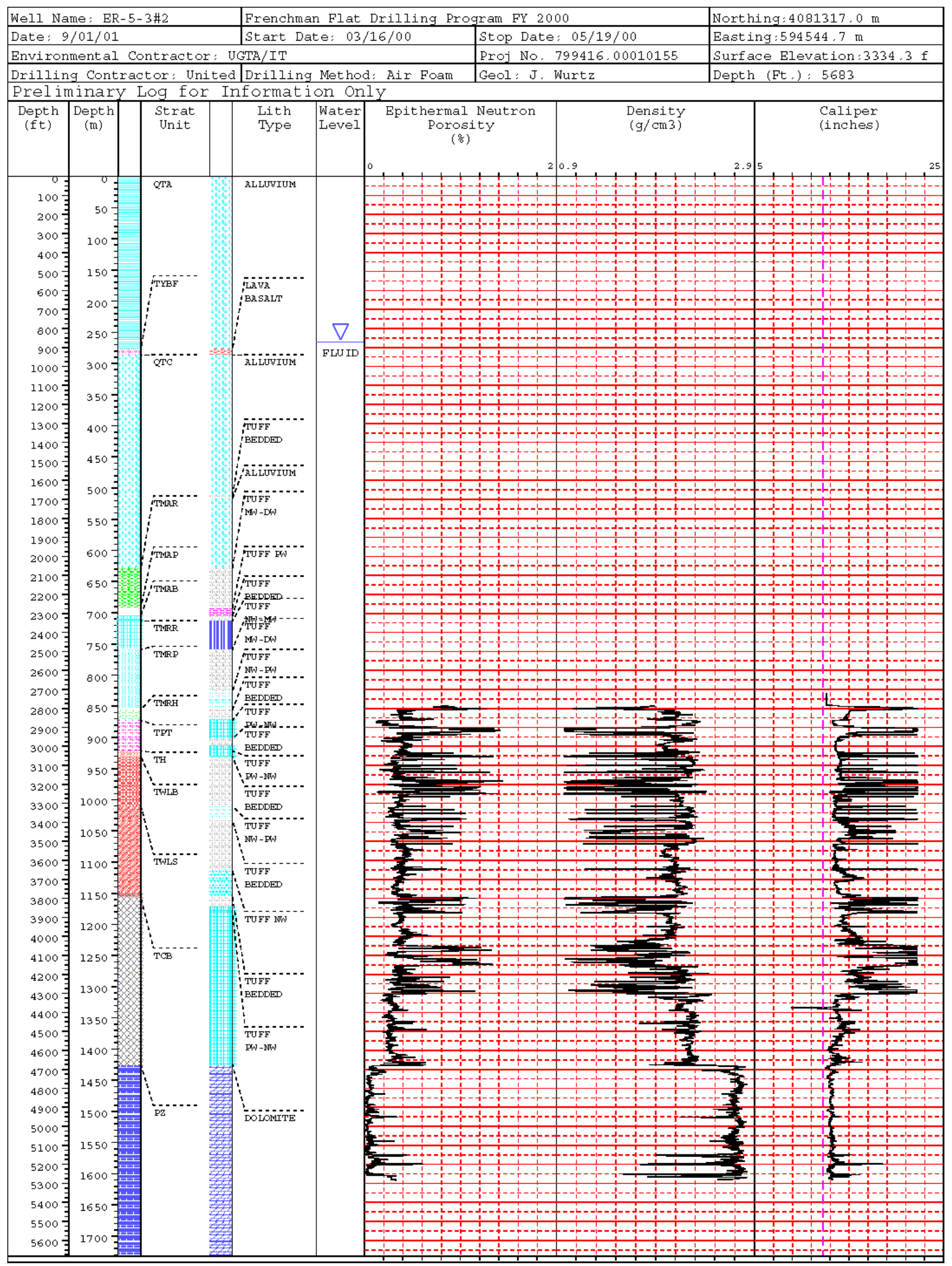

D-2-2 


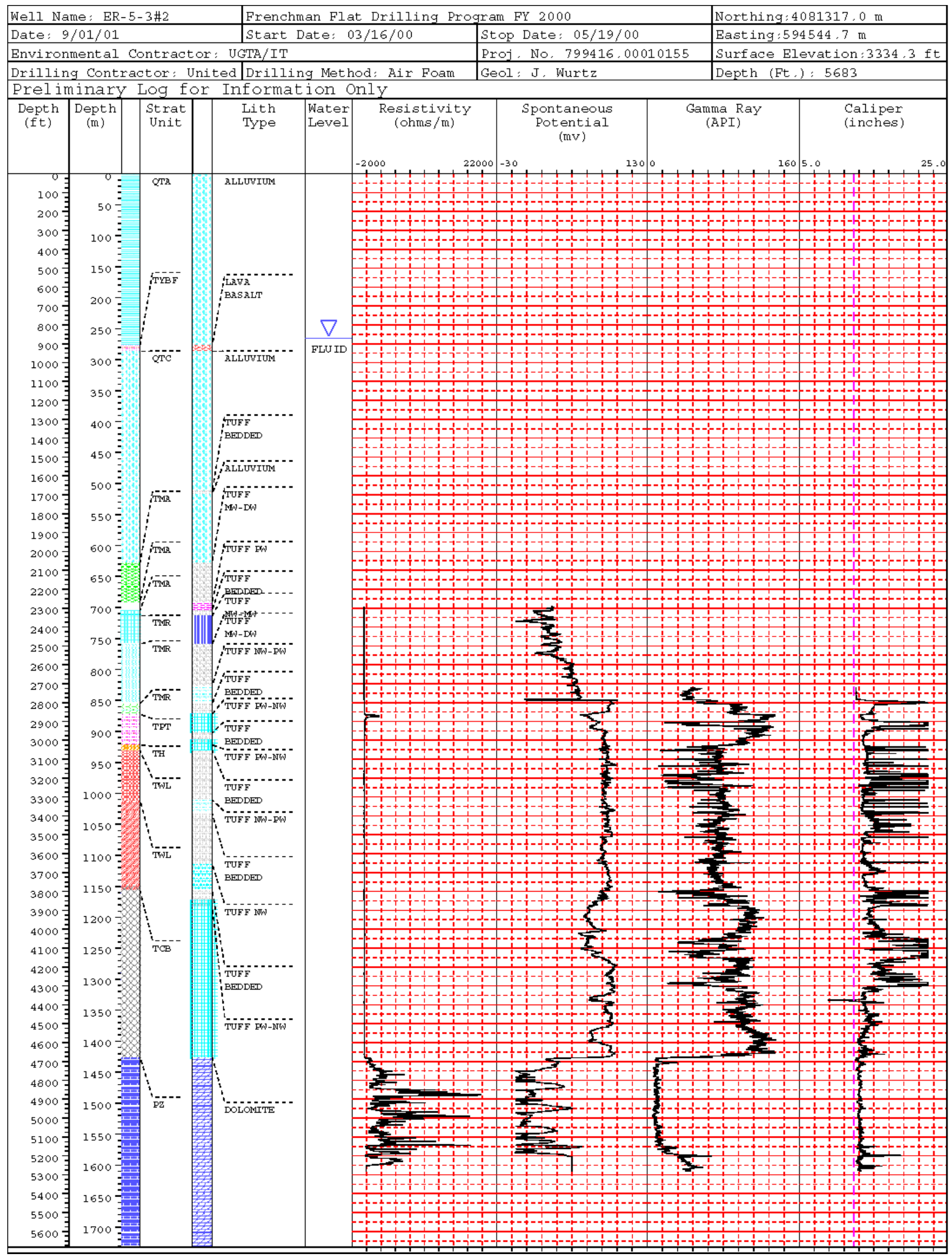

D-2-3 


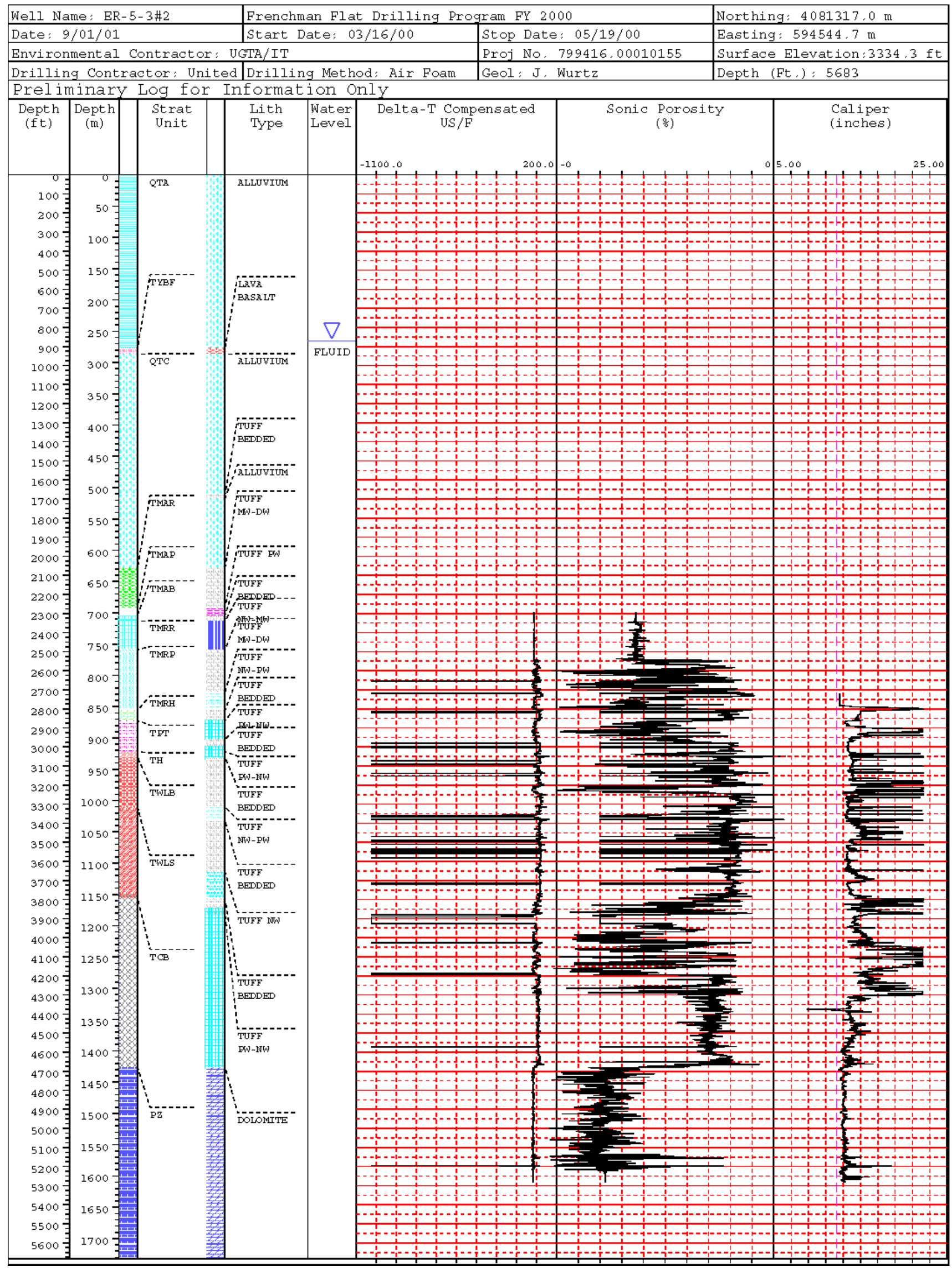




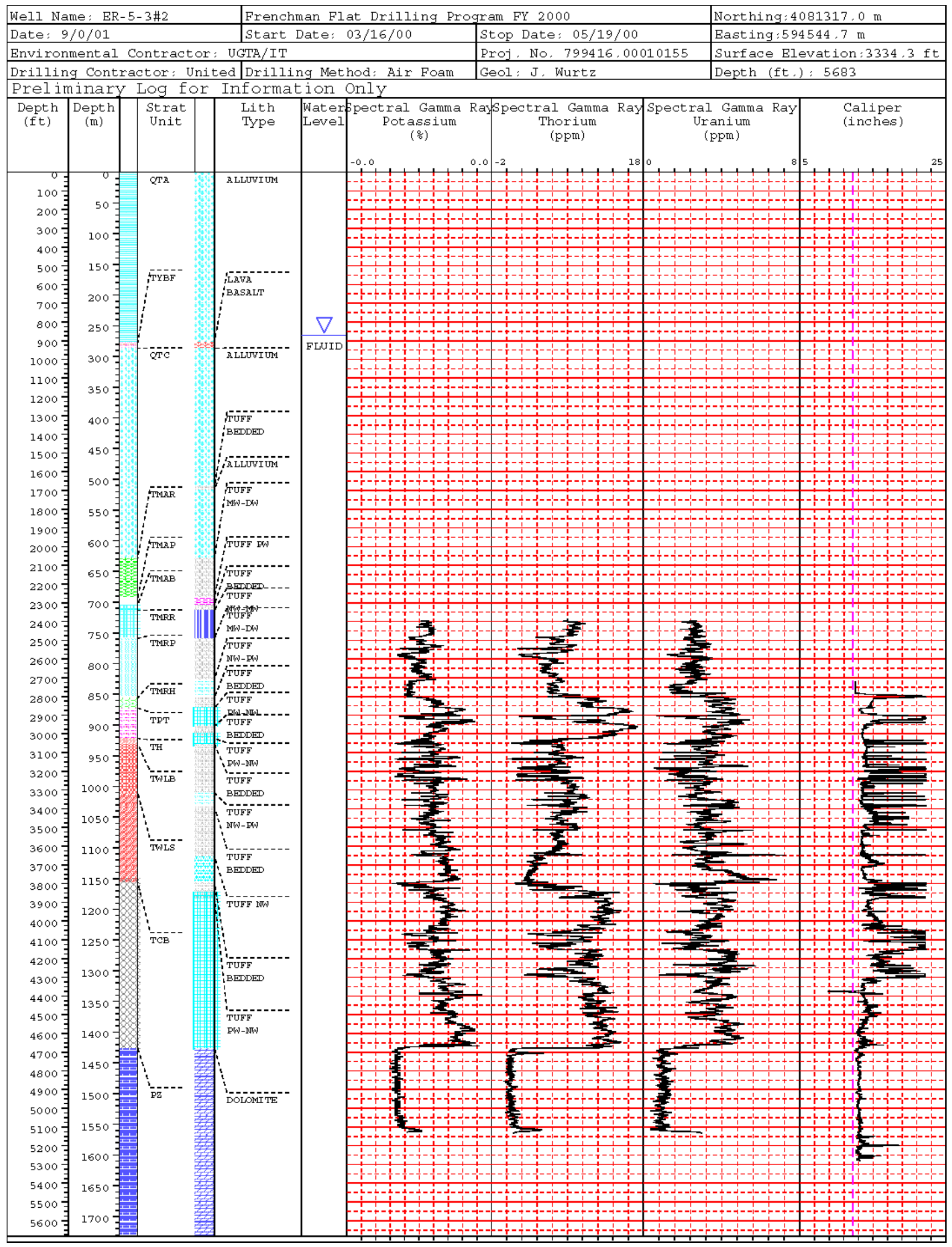

D-2-5 
This page intentionally left blank.

D-2-6 


\section{Distribution List}

$\underline{\text { Copies }}$

W. R. Wilborn

Environmental Restoration Project

5 (2 paper, 3 CDs)

Nevada Site Office

National Nuclear Security Administration

Environmental Restoration Division

P.O. Box 98518, M/S 505

Las Vegas, NV 89193-8518

U.S. Department of Energy

1 paper (uncontrolled)

National Nuclear Security Administration

Nevada Site Office

Technical Library

P.O. Box 98518, M/S 505

Las Vegas, NV 89193-8518

U.S. Department of Energy

2 CDs (uncontrolled)

National Nuclear Security Administration

Nevada Site Office

Nuclear Testing Archive

Public Reading Facility

P.O. Box 98518, M/S 505

Las Vegas, NV 89193-8518

U.S. Department of Energy

Office of Scientific and Technical Information

$1 \mathrm{CD}$ (uncontrolled)

175 Oak Ridge Turnpike

Oak Ridge, Tennessee 37831-0062

K. A. Hoar, Director

1 paper

U.S. Department of Energy

National Nuclear Security Administration

Nevada Site Office

Environment, Safety, and Health Division

P.O. Box 98518, M/S 505

Las Vegas, NV 89193-8518

P. K. Ortego

1 paper

Bechtel Nevada

P.O. Box 98521, MS NLV082

Las Vegas, NV 89193-8521 
Distribution List (continued)

$\underline{\text { Copies }}$

John McCord

1 paper

UGTA Project Manager

Stoller-Navarro Joint Venture

7710 West Cheyenne Ave.

Building 3

Las Vegas, NV 89129

Stoller-Navarro Library

1 paper

Stoller-Navarro Joint Venture

7710 West Cheyenne Ave.

Building 3

Las Vegas, NV 89129

N. M. Becker

1 paper

Los Alamos National Laboratory

P.O. Box 1663, EES-6, M/S F-665

Los Alamos, NM 87545-1663

W. L. Hawkins

Los Alamos National Laboratory

1 paper

P. O. Box 1663, EES-11, M/ F-665

Los Alamos, NM 87545-1663

G. A. Pawloski

1 paper

Lawrence Livermore National Laboratory

P. O. Box 808

Livermore, CA 94551-0808

T. P. Rose

1 paper

Lawrence Livermore National Laboratory

P. O. Box 808

Livermore, CA 94551-0808

B. K. Thompson

1 paper

Water Resources Division, Nevada District

U.S. Geological Survey

160 N. Stephanie Street

Henderson, NV 89074

C. E. Russell

Desert Research Institute

1 paper

755 East Flamingo Road

P.O. Box 19040

Las Vegas, NV 89119-7363 